UNIVERSIDADE DE SÃO PAULO

INSTITUTO DE GEOCIÊNCIAS

Ferramentas de Gestão de Recursos Hídricos: Estudo de Caso na Bacia do Baixo Rio Chambo (Equador)

Sandra Procel Guerra

Orientador: Prof. Dr. Ricardo Hirata

São Paulo

2018 


\title{
INSTITUTO DE GEOCIÊNCIAS
}

\author{
Sandra Procel Guerra
}

Ferramentas de Gestão de Recursos Hídricos: Estudo de Caso na Bacia do Baixo Rio Chambo (Equador)

Orientador: Prof. Dr. Ricardo Hirata

\author{
Tese apresentada ao \\ Instituto de Geociências da \\ Universidade de São Paulo para \\ obtenção do título de \\ Doutor em Ciências. \\ Área de Concentração: \\ Hidrogeologia e Meio ambiente
}

São Paulo 
Autorizo a reprodução e divulgação total ou parcial deste trabalho, por qualquer meio convencional ou eletrônico, para fins de estudo e pesquisa, desde que citada a fonte.

Serviço de Biblioteca e Documentação do IGc/USP

Ficha catalográfica gerada automaticamente com dados fornecidos pelo(a) autor(a) via programa desenvolvido pela Seção Técnica de Informática do ICMC/USP

Bibliotecários responsáveis pela estrutura de catalogação da publicação: Sonia Regina Yole Guerra - CRB-8/4208 | Anderson de Santana - CRB-8/6658

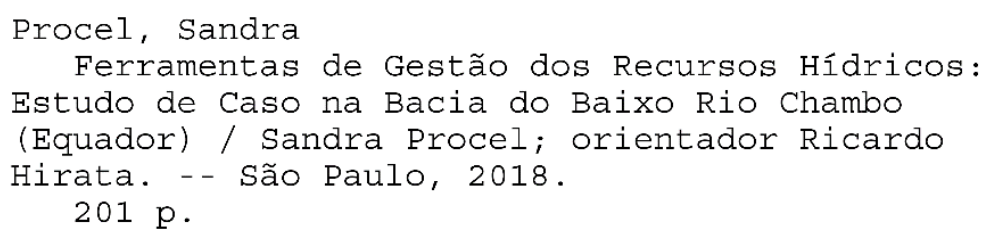

1. Zoneamento. 2. Bacia do Baixo Rio Chambo.. 3. Gestão de recursos hídricos,. 4. Águas superficiais. 5. Águas subterrâneas. I. Hirata, Ricardo, orient. II. Título. 
Ao meu grande e único amor Raúl, à minha amada família: a minha mãe Teresa e meu pai Bolívar, às minhas irmãs e minhas sobrinhas 


\section{AGRADECIMENTOS}

Agradeço às pessoas que de alguma forma contribuíram com a realização deste trabalho.

\section{Brasil}

Ao Prof. Dr. Ricardo Hirata, pela orientação, apoio, ensino e paciência.

A Dra. Claudia Varnier, Pesquisadora do Instituto Geológico do Estado de São Paulo, pela sua imponderável ajuda nas correções. Obrigada pela sua amizade.

Ao Instituto de Geociências da Universidade de São Paulo (IGc-USP), em especial ao Programa de Pós-Graduação em Geologia Sedimentar e Ambiental pela infraestrutura para a realização deste trabalho.

À Coordenação de Aperfeiçoamento de Pessoal de Nível Superior-CAPES, pelo apoio financeiro através da conceição da bolsa de Doutorado pelo período de três anos.

A meus colegas do Laboratório de Modelos Físicos (LAMO) que me ajudaram com a burocracia e com as dicas gerais.

Aos funcionários do IGc, através de Katherine e Alexander pela colaboração e compreensão com a entrega da tese.

\section{Ecuador}

A mi gran amor Raúl, por estar siempre a mi lado, por ser mi cómplice, mi amigo, orientador, profesor, editor todo. Por tenerme paciencia, creer en mí y apoyarme siempre. Gracias por las discusiones en mi área, por las ideas, las correcciones, las malas noches, fines de semana trabajando conmigo. Expreso mi admiración infinita por tu capacidad de razonamiento, tu compresión de los fenómenos físicos, tu orientación y supervisión. Por ser un excelente pesquisador que se desenvuelve en cualquier área y siempre está dispuesto a ayudar y discutir sobre varios temas, inclusive dejando de lado su propia pesquisa. 
A mis queridos Padres por el amor y apoyo incondicional en todas las etapas de mi vida. A mis Hermanas (Ximena, Shadira, Diana) y a mis sobrinos (Mishu, Dany Dome y Jeremy) por brindarme momentos de felicidad repetitivos.

A mi colega, compañera y amiga Carlita, con la que emprendimos este proyecto. Gracias por la paciencia, las conversas técnicas y por compartir los momentos estresantes que se tornaron risas y terapia de conversación. Juntas enfrentamos este desafío, compartimos tantas experiencias y hasta frustraciones por la falta de datos, por las altas emociones que tuvo este proyecto (desde erupciones volcánicas) hasta pérdidas de muestras, desesperación por recursos y paciencia con las personas que nos entrevistamos para realizar la burocracia.

A Benito por la ayuda incondicional, siempre dispuesto a continuar con el proyecto y a seguir adelante. Gracias por las informaciones, las conversas y salidas de campo. Por los contactos y los viajes.

A la UNACH y EP-EMAPAR (Geovany) por la disponibilidad de los datos y por los permisos concedidos en Llío, San Pablo, Riobamba y Yaruquíes.

A la Escuela Politécnica Nacional por la concesión de la licencia de dos años, los cuales fueron aprovechados para desarrollar esta investigación.

A Ana Cabero por el compañerismo en la EPN y por las palabras de aliento para culminar este proyecto. 


\section{RESUMO}

PROCEL, S. 2018. Ferramentas de Gestão de Recursos Hídricos: Estudo de Caso na Bacia do Baixo Rio Chambo (Equador). Tese Doutorado - Instituto de Geociências, Universidade de São Paulo, São Paulo.

Este trabalho teve como objetivo propor um zoneamento territorial baseado nas características fisiográficas e morfológicas da Bacia do Baixo Rio Chambo (BBRCH), situada na Província de Chimborazo (Equador), como ferramenta para gestão de recursos hídricos. A metodologia utilizada abrangeu as seguintes atividades: estimativa da recarga dos aquíferos locais pelos métodos do balanço hídrico e das estimativas darcinianas; elaboração de modelo conceitual de circulação das águas subterrâneas; coletas de amostras de água em poços e nascentes para análises físico-químicas, químicas e isotópicas; além das estimativas de oferta e demanda e dos possíveis conflitos gerados pelo uso e alocação da água. Os resultados obtidos permitiram identificar a ocorrência de três aquíferos do tipo multicamadas de origem vulcanossedimentar (Llío-Guano, Riobamba e Yaruquíes), compostos por depósitos provenientes de erupções vulcânicas do Chimborazo, Igualata, El Altar e Tungurahua. A recarga desses aquíferos provém, principalmente, das cordilheiras ocidental (Chimborazo e Igualata) e oriental (El Altar e Tungurahua) e, em segundo plano, das precipitações locais. As descargas das águas superficiais e subterrâneas fluem para o rio Chambo, considerado como a área de confluência das drenagens da $\mathrm{BBRCH}$. Os dados hidroquímicos e isotópicos $\left(\delta^{18} \mathrm{O}\right.$ e $\left.\delta^{2} \mathrm{H}\right)$ indicaram a existência de águas de diferentes composições e origens. As águas dos aquíferos Llío-Guano e Riobamba são classificadas como bicarbonatadas cálcio-magnesianas, desde ligeiramente ácidas a neutras, com valores enriquecidos de $\delta^{18} \mathrm{O}$ e $\delta^{2} \mathrm{H}$. As águas do Aquífero Yaruquies e das nascentes em Cubijíes são, respectivamente, bicarbonatadas sódicas a sulfatadas cálcio-magnesianas, com valores mais empobrecidos de $\delta^{18} \mathrm{O}$ e $\delta^{2} \mathrm{H}$, indicando que existe influência das atividades vulcânicas do El Altar. A área foi dividida em oitos zonas distintas (Z1, Z2, Z3, Z4, Z5, Z6, Z7 e Z8), com características fisiográficas e morfológicas particulares. Este zoneamento servirá como referência para a elaboração do plano de bacia no município de Riobamba e demais províncias equatorianas.

Palavras-chave: zoneamento territorial, águas superficiais, águas subterrâneas, gestão de recursos hídricos, Bacia do Baixo Rio Chambo. 


\begin{abstract}
PROCEL, S. 2018. Water Resources Management Tools: Case Study in the Lower Chambo River Basin (Ecuador). Tese (Doutorado) - Instituto de Geociências - Universidade de São Paulo, São Paulo.
\end{abstract}

This work aimed to propose a territorial zoning based on the physiographic and morphological characteristics of the Lower Chambo River Basin (LCRB), located the Province of Chimborazo (Ecuador), as a tool for the water resources management. The methodology used included the following activities: estimation of recharge from the local aquifers using the water balance and Darcinian estimates methods, conceptual model of groundwater circulation, groundwater and springs sampling for physico-chemical, chemical and isotopic analyses, as well as the estimates of supply and demand and the possible conflicts generated by the use and distribution of water. The results allowed to identify the occurrence of three multilayer aquifers of volcanosedimentary origin (LlíoGuano, Riobamba and Yaruquíes), composed of volcanic deposits from eruptions of Chimborazo, Igualata, El Altar and Tungurahua. The recharge of those aquifers comes, mainly, from the western (Chimborazo and Igualata) and eastern (El Altar and Tungurahua) mountain range and, secondarily, comes from the local precipitation. The discharge zone of surface water and groundwater comprises the Chambo River, considered as the confluence area of the drainages located in LCRB. The hydrochemical and isotopic data $\left(\delta^{18} \mathrm{O}\right.$ and $\left.\delta^{2} \mathrm{H}\right)$ indicated the existence of waters with different compositions and origin. The Llío-Guano and Riobamba aquifers are composed of calcium-magnesium bicarbonate waters, from slightly acidic to neutral, with enriched $\delta^{18} \mathrm{O}$ and $\delta^{2} \mathrm{H}$ values. The Yaruquíes aquifer and the springs located in Cubijíes settlement are constituted, respectively, of sodium bicarbonate to calcium-magnesium sulfate waters with more depleted $\delta^{18} \mathrm{O}$ and $\delta^{2} \mathrm{H}$ values, indicating influence of the volcanic activities from El Altar. The area was divided into eight distinct zones (Z1, Z2, Z3, Z4, Z5, Z6, Z7, Z8), with particular morphological and water availability characteristics. The zoning will serve as a reference for the elaboration of water resource management plans in the Riobamba municipality and other Ecuadorian provinces.

Keywords: territorial zoning, surface waters, groundwater, water resources management, Lower Chambo River Basin. 


\section{SUMÁRIO}

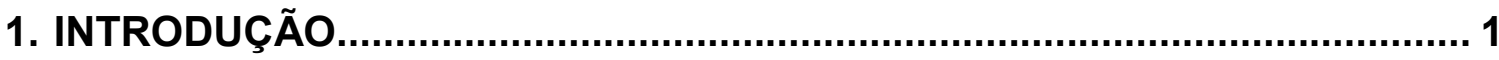

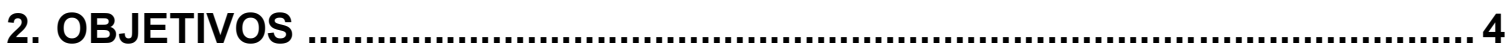

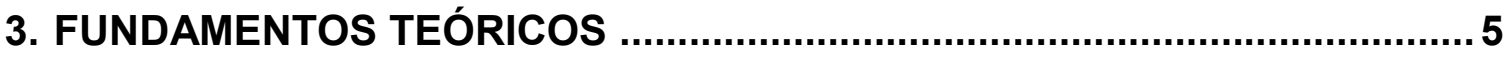

3.1 Consequências das mudanças climáticas e o recuo das geleiras na região andina para o gerenciamento de recursos hídricos .........................................5

3.2 Principais conceitos, elementos e estudos de caso para a Gestão integrada

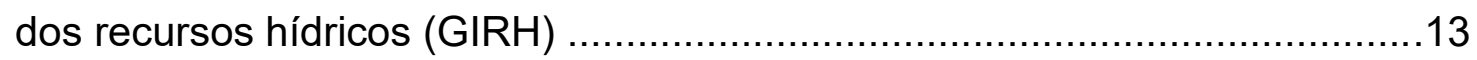

3.3 Políticas, normativas e instituições envolvidas na gestão dos recursos hídricos no Equador

3.4 Políticas, normativas e instituições envolvidas na gestão de recursos hídricos no Brasil

3.5 Análise comparativa dos modelos e instrumentos de GIRH no Equador e no Brasil

4. ÁREA DE ESTUDO

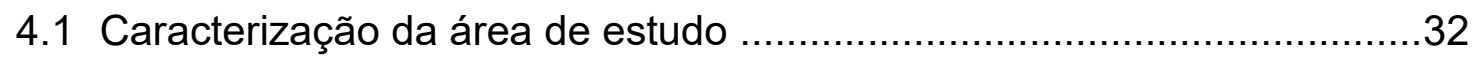

4.1.1 Localização da área de estudo............................................... 32

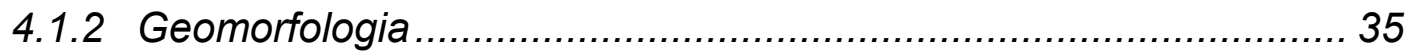

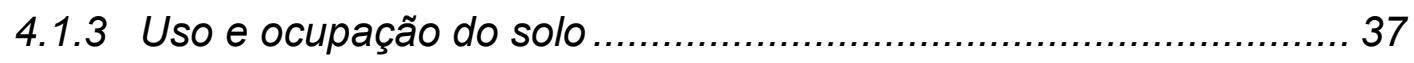

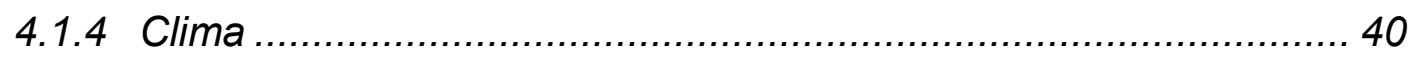

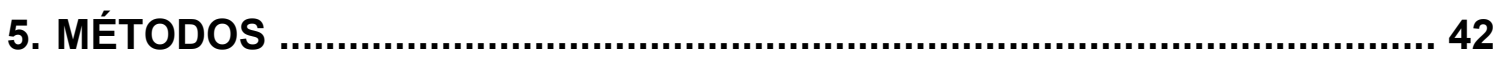

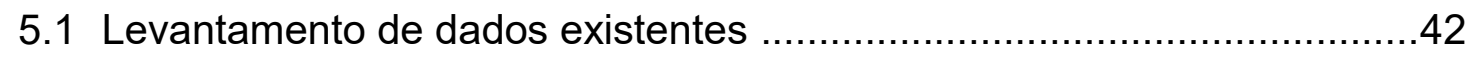

5.1.1 Levantamento de bases cartográficas, dados meteorológicos,

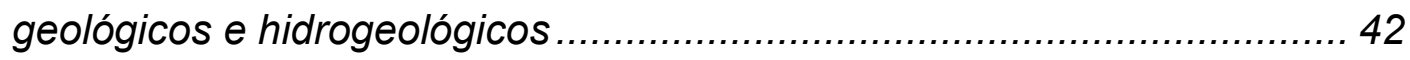

5.1.2 Levantamento das informações dos poços e nascentes existentes na

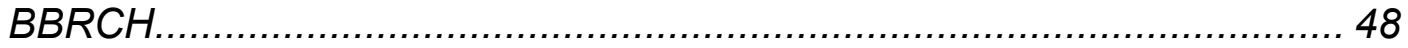

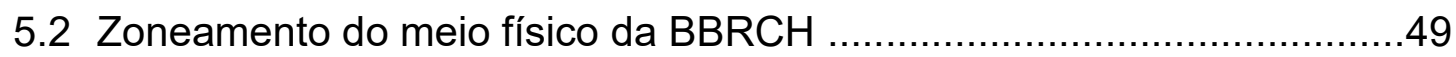

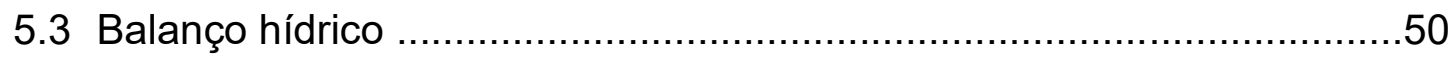

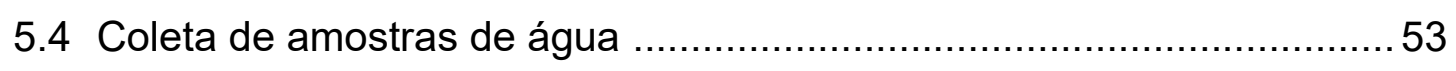

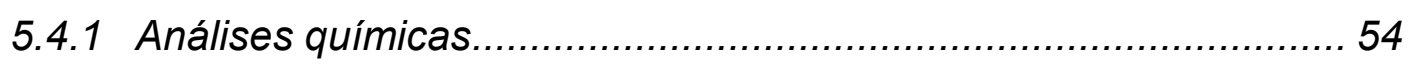




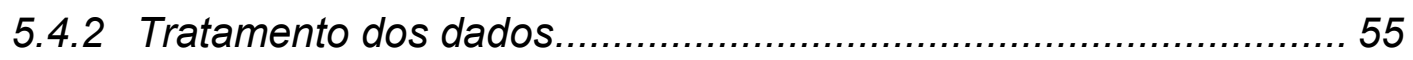

5.5 Uso dos isótopos ${ }^{2} \mathrm{H} \mathrm{e}{ }^{18} \mathrm{O}$ na identificação da origem da água 57

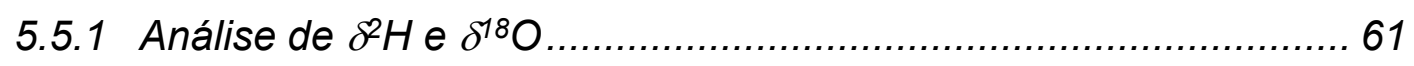

5.5.2 Instalação de coletor e amostragem de água de chuva. ................. 62

5.6 Modelo Hidrogeológico Conceitual 64

5.7 Técnicas de zoneamento para a gestão de recursos hídricos..................65

5.7.1 Zoneamento da área para fins de gestão integrada de recursos

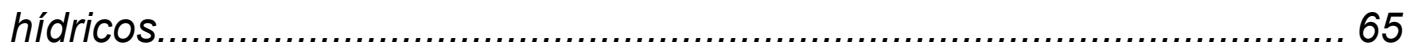

5.7.2 Problemas relevantes na gestão de recursos hídricos na $B B R C H .74$

\section{RESULTADOS} . .76

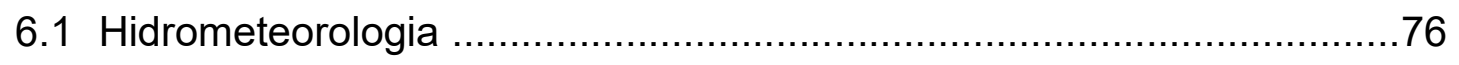

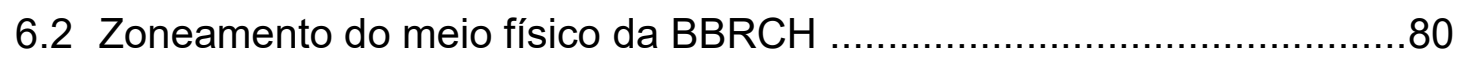

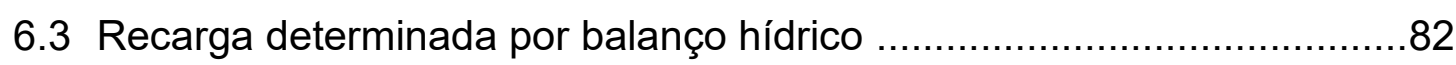

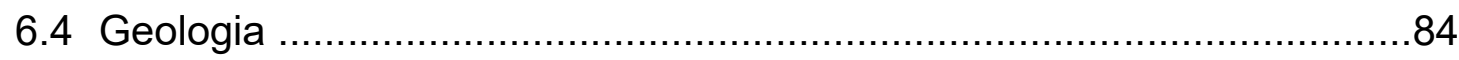

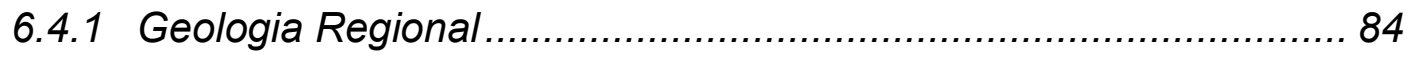

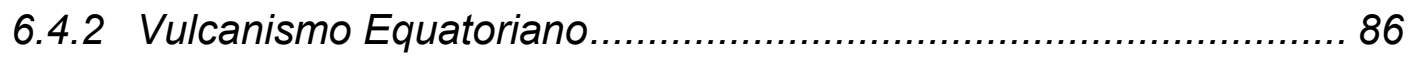

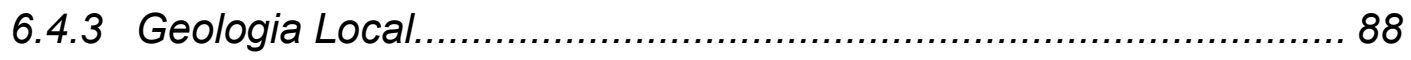

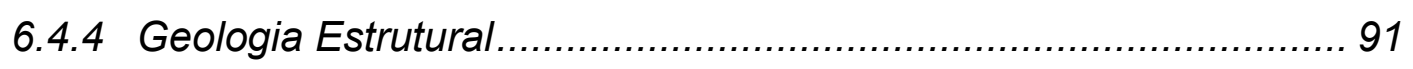

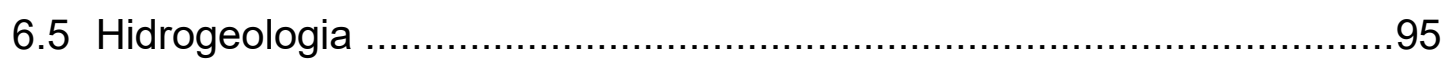

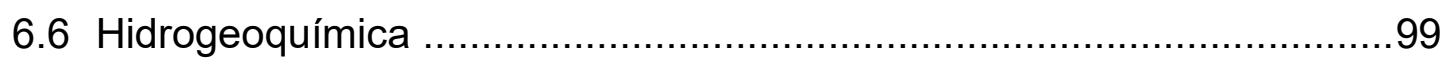

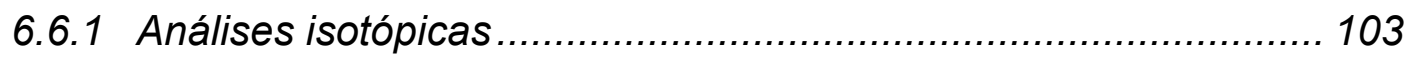

6.7 Modelo Hidrogeológico Conceitual ................................................110

6.8 Proposta de gestão de recursos hídricos na área de estudo ...............111

6.8.1 Oferta e demanda de água na $\mathrm{BBRCH}$.................................... 111

6.8.2 Problemas relevantes na gestão de recursos hídricos na $B B R C H 127$

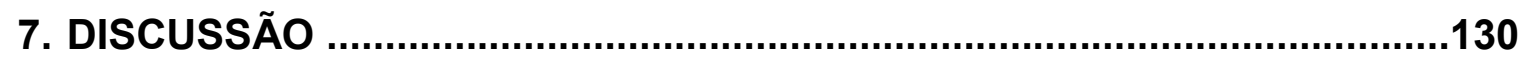

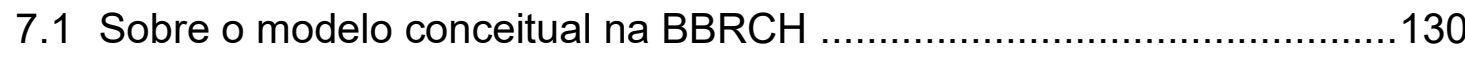

7.2 Contribuições para o planejamento integrado de recursos hídricos .......131

8. CONCLUSÕES E RECOMENDAÇÕES …..............................................143

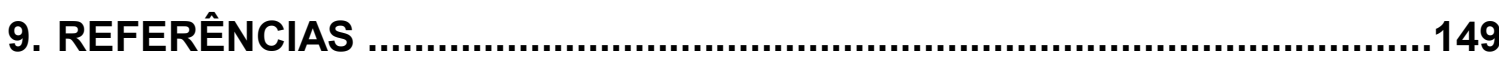

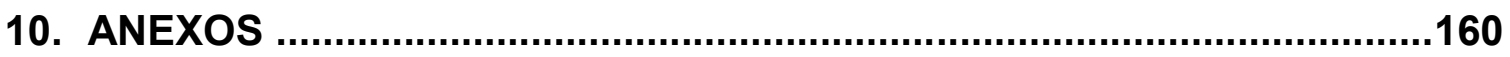




\section{LISTA DE FIGURAS}

Figura 1. Perda glacial do Chacaltaya (Bolívia). Fonte: a) Francou et al., 2000; b) Ramirez, 2013.

Figura 2. Dados evolutivos referentes à área e comprimento de 10 geleiras monitoradas nos Andes Centrais entre 1930 e 2007 (Fonte: Francou et al., 2007).

Figura 3. Perda das superfícies da geleira Pastoruri, situada na Cordilheira Blanca; (Ancash Peru). Fonte http://natura-medioambiental.com/. 9

Figura 4. Perda glacial do Chimborazo. a) 1962, b)1997, c) 1986-2013. Fonte: Cáceres (2010); La Franierre (2014). 10

Figura 5.Perda glacial em alguns vulcões no Equador: a) Cotopaxi; b) Antisana. Fonte: Cáceres, (2006; 2010). 12

Figura 6. Principais regiões do Equador: Litoral, Serra e Amazônia. Divisão dos Andes Equatorianos em cordilheira Real, Ocidental e os segmentos do Vale Interandino (Vale Interandino Norte, Central e Sul). 33

Figura 7.Localização da área de estudo na organização Político-Administrativo do Equador. a) Província de Chimborazo; b) Limites da BBRCH; c) BBRCH com as principais geleiras vulcânicas.

Figura 8. Principais fações morfológicas, geleiras vulcânicas e áreas urbanas na BBRCH. 35

Figura 9. Localização da $\mathrm{BBRCH}$ na demarcação hidrográfica do rio Pastaza. 36

Figura 10. Drenagem da BBRCH. Principais rios orientais e ocidentais. ........ 37

Figura 11. Classificação taxonômica dos solos na BBRCH ......................... 38

Figura 12.Uso e ocupação do solo identificando as áreas urbanas e rurais. .. 39

Figura 13.Tomografias elétricas e colunas estratigráficas realizadas no campo para a análises e correlações das principais formações e unidades litológicas presentes na BBRCH.

Figura 14. Estações climatológicas, pluviométricas e hidrológicas ativas e inativas na área de estudo.

Figura 15. Método da dupla massa para a validação de dados de precipitação em séries mensais e anuais. 46

Figura 16. Poços e nascentes cadastradas na $\mathrm{BBRCH}$. 49 
Figura 17. Zoneamento e intervalos de declividade: declividades de $<2 \%$ baixa declividade (relevos com trechos de planície junto à hidrografia da bacia); de $2 \%$ a $7 \%$ declividades moderadas (relevos pouco acidentados) e $>7 \%$ altas declividades (relevos mais acidentados).

Figura 18. Esquema da aplicação da Lei de Darcy para a estimação da recarga lateral devida ao Chimborazo e Igualata. As setas representam a direção do fluxo da água. 52

Figura 19. Pontos de coleta e amostragem de água na campanha realizada em agosto/2016. 53

Figura 20. Procedimentos de coleta e preservação de amostras: Purga e coleta (a e b), medição dos parâmetros físico-químicos (c) e titulação volumétrica (d). 56

Figura 21. Pontos de coleta de água de chuva, poços e nascentes para análises de isótopos $\square 2 \mathrm{H} \mathrm{e} \square 18 \mathrm{O}$. 63

Figura 22. Demanda de água de acordo com o uso de terras agrícolas nas áreas estabelecidas na BBRCH.

Figura 23. Vazões médias (no período abril e junho de 2017) para os diferentes trechos dos rios Guano, Chimborazo e Chibunga. Vazões médias anuais dos rios Cebadas, Guamote, Guargualla, Alao, Blanco e Puela (CNRH, 2007). 70

Figura 24. Ilustração da estimativa da vazão superficial disponível na zona 1. As linhas azuis representam os rios Guano (dividido em trechos) e Chambo. Os valores correspondem às vazões medidas em cada ponto do rio em $\mathrm{m} 3 / \mathrm{s}$. As linhas cinzas representam afluentes do rio e as cores em cada trecho representam: vermelho: trecho com contribuição excluída, verde: trecho com contribuição considerada e amarela: trecho com contribuição dividida pela metade. 72

Figura 25. Variação da precipitação média mensal durante um ano: a) grupo 1(M0057, M0133, M0243, M0393, M0394, M0406, M0408, M1036) e b) grupo 2 (M0400, M0407, M0390 e M0396).

Figura 26. Distribuição espacial da precipitação $(\mathrm{mm})$ com série de dados interanuais das estações climatológicas e pluviométricas ativas e fora de operação. 78

Figura 27. Distribuição mensal e temporal da temperatura da $\mathrm{BBRCH}$. 79 
Figura 28. Zoneamento da área de estudo mostrando as 8 zonas delimitadas a partir da morfologia, taxonomia (tipos de solos andinos) e ocupação do solo (urbano e rural). 81

Figura 29. Principais estruturas e terrenos alóctones e autóctones que formam a Cordilheira Ocidental, Oriental e o Vale Interandino (Reyes, 2008). 85

Figura 30. Divisão do arco vulcânico Plio-Quaternário do Equador. Evidencia-se três lineamentos de oeste ao leste: frente vulcânico, arco principal e levantamento subandino, segundo o ponto de vista da atividade vulcânica (Modificado de Bernard e Andrade, 2011).

Figura 31. Geologia simplificada da área de estudo. Modificado de Salguero, 2017; Yanez,2016; Barba, 2008. 93

Figura 32. Seções geológicas e hidrogeológicas A-A', B-B' e C-C' na área de estudo. 94

Figura 33. Potenciometria esquemática da zona de estudo. As direções preferenciais das águas subterrâneas ocorrem desde o Chimborazo e Igualata (cordilheira ocidental), El Altar e Tungurahua, (cordilheira oriental) para o rio Chambo. 98

Figura 34. Localização dos pontos de amostragem (poços e nascentes) para campanha de 2016.

Figura 35. Diagrama de Piper e classificação das águas na $\mathrm{BBCH}$. A análise contempla os poços (círculos) e as nascentes (triangulo) nas localidades de Llío (círculo azul), San Pablo (triangulo azul), Guano (triangulo lilás), Cubijíes (triangulo marrom) e Riobamba (círculo cinza) e Yaruquíes (círculo cinza escuro). 103

Figura 36. Relação isotópica entre $\square 180$ e $\square 2 \mathrm{H}$ para as águas subterrâneas localizadas na BBRCH. 106

Figura 37. Relação isotópica entre a altitude e $\square 180$ para as águas subterrâneas localizadas na BBRCH. 106

Figura 38. Relação isotópica entre $\square 180$ e $\square 2 \mathrm{H}$ das águas da chuva nas localidades: a) Ilapo, b) Guano e c) Riobamba no período de 8 meses (10/2016 a 05/2017). 109

Figura 39. Esquema adimensional do modelo conceitual da BBRCH. Principais direções de fluxo subterrâneo e formações geológicas pelas que circula a água. 
Figura 40. Demandas setoriais de água: a) no Equador e b) na $\mathrm{BBRCH}$...... 112

Figura 41. Demandas setoriais na zona 1, que mostra as outorgas com suas vazões (L/s) e os diferentes usos (Irrigação, doméstico, bebedouro, cultivo de peixe e hidrelétrica). Os tamanhos dos círculos são proporcionais à vazão outorgada.

Figura 42. Demandas setoriais de água na zona 2, que mostra as outorgas com suas vazões (L/s) e os diferentes usos (Irrigação, doméstico, bebedouro, cultivo de peixe e hidrelétrica). Os tamanhos dos círculos são proporcionais à vazão outorgada.

Figura 43. Demandas setoriais de água na zona 3, que mostra as outorgas com suas vazões (L/s) e os diferentes usos (Irrigação, doméstico, bebedouro, cultivo de peixe). Os tamanhos dos círculos são proporcionais à vazão outorgada.

Figura 44. Demandas setoriais de água na zona 4, que mostra as outorgas com suas vazões (L/s) e os diferentes usos (Irrigação, doméstico, bebedouro, cultivo de peixe). Os tamanhos dos círculos são proporcionais à vazão outorgada.

Figura 45. Demandas setoriais de água na zona 5, que mostra as outorgas com suas vazões (L/s) e os diferentes usos (Irrigação, doméstico e bebedouro). Os tamanhos dos círculos são proporcionais à vazão outorgada. 120

Figura 46. Demandas setoriais de água na zona 6 e 7, que mostra as outorgas com suas vazões (L/s) e os diferentes usos (Irrigação, doméstico, bebedouro, cultivo de peixe). Os tamanhos dos círculos são proporcionais à vazão outorgada.

Figura 47. Demandas e ofertas domésticas em Riobamba, considerando as projeções populacionais até 2040. Demandas mínimas, médias e máximas requeridas para o uso doméstico. 123

Figura 48. Demandas e ofertas domésticas em Guano, considerando as projeções populacionais até 2040. Demandas mínimas, médias e máximas requeridas para o uso doméstico.

Figura 49. Demandas setoriais de água na zona 8, que mostra as outorgas com suas vazões (L/s) e os diferentes usos (Irrigação, doméstico, bebedouro e cultivo de peixe). Os tamanhos dos círculos são proporcionais à vazão outorgada. 
Figura 50. Captação de água subterrânea através de 8 poços e uma nascente localizados na localidade de Llío e San Pablo respectivamente no Município de Guano. 7 poços na cidade de Riobamba e 1 em Yaruquíes (Município de Riobamba) para abastecimento doméstico de $70 \%$ da população do município. Sistema de captação e alocação operado pela EP-EMAPAR (EPEMAPAR, 2017).

Figura 51. Vulnerabilidade hídrica nas 8 zonas definidas na $B B R C H$. Vulnerabilidade alta $(n<0)$, média $(0<n<100 \%)$ e baixa $(n>100 \%)$ no que respeita ao excedente ou déficit do recurso hídrico.

Figura 52. Aquedutos artesanais para captação de água superficial e posterior uso em irrigação.

Figura 53. Proposta para prever um possível desabastecimento de água nas zonas com vulnerabilidade alta e média na $\mathrm{BBRCH}$. 142 


\section{LISTA DE TABELAS}

Tabela 1. Comparação das principais características de implementação da GIRH no Equador, no Brasil e no Estado de São Paulo. .............................. 29

Tabela 2. Estações meteorológicas escolhidas para a BBRCH.....................46 46

Tabela 3. Estações para análises de temperatura na BBRCH. .................... 47

Tabela 4. Estações hidrológicas escolhidas para a BBRCH........................4 47

Tabela 5. Métodos analíticos adotados para a determinação dos parâmetros em

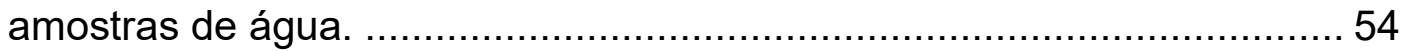

Tabela 6. Demanda de água para fins agrícolas segundo a FAO (1991)....... 66

Tabela 7. Crescimento demográfico e projeções populacionais nas zonas urbanas da BBRCH (INEC, 2010) .......................................... 68

Tabela 8. Localização e vazão média estimada (abril e junho 2017) em cada ponto do percurso do rio Guano. A última coluna representa as contribuições da água superficial da zona 1 para cada trecho do rio.......................... 73

Tabela 9. Zoneamento da área de estudo. 8 zonas definidas de acordo com as principais características geomorfológicas.

Tabela 10. Aplicação da Lei de Darcy para estimação da recarga lateral devida ao Chimborazo e Igualata.

Tabela 11. Capacidade de permeabilidade do solo considerando, tipo de solo, uso e ocupação de solo e a declividade nas zonas estabelecidas neste estudo.

Tabela 12. Valores em mm/ano observados para a precipitação, recarga evapotranspiração, escoamento superficial na $\mathrm{BBRCH}$.

Tabela 13. Parâmetros hidrogeológicos dos poços nos Aquíferos Guano (LlíoGuano, Riobamba e Yaruquíes). 96

Tabela 14. Dados dos poços tubulares e nascentes amostradas em 2016 e resultados físico-químicos das águas subterrâneas da área de estudo.. 100

Tabela 15. Resultados analíticos químicos (concentração em $\mathrm{mg} / \mathrm{L}$ ) das

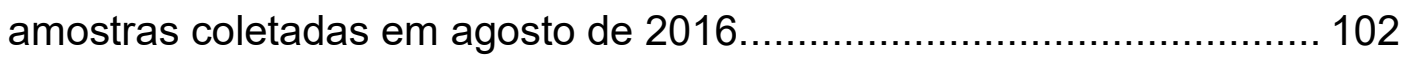

Tabela 16. Resultados das análises de $\delta 180 \%$ e $\delta 2 H \%$ das amostras coletadas nas localidades de Llío, Guano, Riobamba e Cubijíes. 104 
Tabela 17. Razões isotópicas das águas de chuvas mensais (10/2016 a 05/2017) e do gelo derretido do Chimborazo amostrado por La Frenierre (2014) 108

Tabela 18. Demanda mínima de água requerida para irrigação na zona 1 ... 112

Tabela 19. Demanda e oferta estimada para a zona 1............................... 113

Tabela 20. Demanda mínima de água para irrigação na zona 2................. 115

Tabela 21. Demanda e oferta estimada para a zona 2 …........................... 115

Tabela 22. Demanda mínima de água para irrigação na zona 3................. 116

Tabela 23. Demanda e oferta estimada para a zona 3............................. 117

Tabela 24. Demanda mínima de água para irrigação na zona 4................. 118

Tabela 25. Demanda e oferta estimada para a zona 4 .............................. 118

Tabela 26. Demanda mínima de água para irrigação na zona 5 .................. 119

Tabela 27.Demanda e oferta estimada para a zona 5............................... 120

Tabela 28. Demanda e oferta estimada para a zona 6.............................. 121

Tabela 29.Demanda e oferta estimada para a zona 7................................. 123

Tabela 30.Demanda mínima de água para irrigação na zona 8. ................... 124

Tabela 31. Demanda e oferta estimada para a zona 8............................. 125

Tabela 32. Oferta potencial de água superficial e oferta instalada subterrânea, oferta potencial subterrânea devido à recarga local nas zonas definidas na

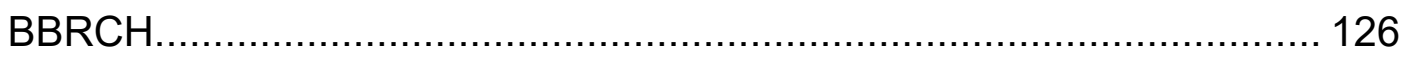

Tabela 33. Ofertas e demandas e \% do excedente hídrico para as 8 zonas. . 133

Tabela 34.Recarga local e lateral nas 8 zonas da BBRCH........................... 134

Tabela 35.Proposta de planejamento para a gestão de recursos hídricos na $\mathrm{BBRCH}$ ao curto, médio e longo prazo. 136 



\section{INTRODUÇÃO}

O processo de urbanização tem ocorrido em ritmo acelerado nas últimas décadas em diversas cidades da América Latina e Caribe. Quatro em cada cinco pessoas moram em cidades com crescimento urbano desordenado e com oferta limitada de água (UNHABITAT, 2011). Além disso, fatores como as mudanças climáticas globais poderão reduzir a disponibilidade hídrica e causar grandes prejuízos econômicos, sociais e ecológicos (Trenberth \& Philip, 2007); (Meehl, 2007); (Retamal, Rojas, \& Parra, 2011); (López, Manzano, \& Ramírez, 2017)

No Quarto Relatório Científico do Painel Intergovernamental de Mudanças Climáticas (IPCC, 2008) são apresentadas evidências de que as mudanças do clima no mundo exerceriam um forte impacto nos recursos hídricos, especialmente em áreas caracterizadas pela regressão das geleiras e, com maior rigor, nos países menos desenvolvidos (Immerzeel, Luduvicus, Beek, Marc, \& Bierkens, 2010); (Baraer, et al., 2012); (Martínez \& Patiño, 2012). Tais problemas já são realidade em vários países e, futuramente, prevê-se que a oferta de água será cada vez mais irregular (Bates, Kundzewicz, \& Palutikof, 2008).

Durante muito tempo, a água no Equador era considerada um recurso infinito. No entanto, o mau uso, aliado à crescente demanda, vem preocupando os responsáveis pela gestão dos recursos hídricos no País. Esse cenário se dá em função da diminuição da disponibilidade de água (quantidade e qualidade) e dos conflitos que se estabeleceram entre os usuários, conforme dados apontados pela Secretaria Nacional de Água (SENAGUA, 2012). De acordo com a legislação equatoriana, a mudança da interpretação que considerava a água como um recurso infinito foi incorporada na Lei de Uso e Aproveitamento da Água de 2014 (Equador, 2014) que, entre outras medidas, permitiu a criação de uma legislação específica, além dos Conselhos de Bacias Hidrográficas. No entanto, ainda existe uma carência de informações sobre os mananciais de água (origem, disponibilidade e qualidade), bem como em relação aos usuários, suas demandas e às instituições gestoras dos recursos hídricos.

No Equador, o aumento da demanda de água e a diminuição das dimensões das geleiras afetam a sustentabilidade do abastecimento de água, 
tanto em zonas urbanas como rurais. Ressalta-se que as geleiras constituem a principal fonte de abastecimento público do país, sendo parte das cabeceiras dos sistemas fluviais e a recarga dos sistemas hídricos subterrâneos (Bradley, 2006); (Vuille, 2008); (Baraer, et al., 2012). As áreas urbanas na província de Chimborazo (por exemplo: Riobamba, Guano e Chambo) são abastecidas principalmente pelas águas subterrâneas. Já nas comunidades indígenas, a irrigação para agricultura e as pastagens utilizam-se de águas superficiais e subterrâneas. Atualmente é desconhecida a quantidade e a qualidade da água da Bacia do Baixo rio Chambo (BBRCH), assim como sua origem, se proveniente da precipitação ou da água de degelo do vulcão Chimborazo.

O problema da água na BBRCH possui diferentes aspectos: i) a população urbana recebe a água captada e tratada pela Empresa Municipal de Água Potável e Esgoto da Cidade de Riobamba (EP-EMAPAR), já a população rural tem que buscar sua própria água, limitando seu abastecimento; ii) o nível de renda das pessoas afeta o acesso ao recurso, devido à necessidade de pagamento de outorgas; iii) existência de um déficit na infraestrutura de distribuição de água nas áreas urbanas(redes antigas e falta de manutenção); iv) baixa interação entre os usuários e as instituições gestoras do recurso hídrico; v) pouca informação técnica sobre origem, disponibilidade, qualidade, função e serviços dos recursos hídricos na bacia, tornando o processo de outorga apenas uma exigência burocrática, sem respeitar as disponibilidades hídricas da bacia e as interferências entre usuários; vi) problemas de exploração entre territórios de diferentes jurisdições nos municípios de Guano e Riobamba; e vii) o descarte sem tratamento de efluentes urbanos que provoca a contaminação dos cursos d'água, impossibilitando o uso para os irrigantes e as populações rurais.

Nesse sentido, o presente trabalho propõe oferecer ferramentas para melhorar a gestão dos recursos hídricos na $\mathrm{BBRCH}$. Para isso, foi realizada uma análise do uso integrado dos recursos superficiais e subterrâneos, considerando três formas de abordagem: técnica, social e administrativa. Na componente técnica foram analisadas as fontes de água, suas origens, disponibilidade, qualidade, função e serviços que desempenham; no aspecto social, foram estudados os relacionamentos entre os usuários, considerando critérios como: i) tipos de usuários (pessoas com diferentes usos e formas de aproveitamento da água) e ii) principais conflitos existentes ou potenciais entre eles em relação às 
concessões de água; e a dimensão administrativa foi examinada a partir das relações entre os usuários, a sociedade e o Estado equatoriano. 


\section{OBJETIVOS}

Este trabalho tem como objetivo caracterizar a dinâmica das águas superficiais e subterrâneas, identificar os usuários, os possíveis conflitos de uso, com vistas a propor programas, projetos e ações para a gestão dos recursos hídricos na Bacia do Baixo Rio Chambo (BBRCH). Assim também promover o uso racional e controlado desses recursos, a sua conservação e proteção, tanto em áreas urbanas como rurais.

São objetivos específicos:

$\checkmark$ Determinar a disponibilidade de água superficial e subterrânea, relacionando-as com as demandas e outorgas na $\mathrm{BBRCH}$;

$\checkmark$ Explicitar a relação entre os usuários da água e o marco jurídico e institucional de gestão dos recursos hídricos, assim como sua aplicabilidade na área de estudo;

$\checkmark$ Realizar uma análise comparativa entre o gerenciamento dos recursos hídricos no Equador e no Brasil, com base nas políticas públicas nacionais e nos instrumentos normativos e técnicos atualmente em vigor com intuito de reconhecer os avanços e falências;

$\checkmark$ Avaliar a vulnerabilidade dos recursos hídricos superficiais e subterrâneos e propor as possíveis soluções em cada zona da BBRCH, com intuito de propor ações (conservação ou proteção) para a gestão. 


\section{FUNDAMENTOS TEÓRICOS}

Este capitulo está organizado em duas seções. Na primeira são abordados os conceitos sobre mudanças climáticas na região andina e suas consequências na disponibilidade dos recursos hídricos, além das metodologias e técnicas quantitativas e qualitativas utilizadas para a compreensão de tais processos, com enfoque nos Andes Equatorianos. A segunda seção, por sua vez, abrange uma descrição teórica dos principais conceitos e elementos envolvidos na Gestão Integrada de Recursos Hídricos (GIRH), com apresentação de estudos de caso (metodologias e técnicas) adotados em pesquisas que envolvem quantidade e qualidade de água superficial e subterrânea.

\subsection{Consequências das mudanças climáticas e o recuo das geleiras na região andina para o gerenciamento de recursos hídricos.}

A temática ambiental e a preocupação mundial sobre as mudanças climáticas têm sido o eixo responsável de uma série de ações globais, as quais destacam-se: i) a Primeira Conferência Mundial sobre Clima (Genebra, 1979), ii) a criação do Painel Intergovernamental sobre Mudanças Climáticas (IPCC), organizado pelo Programa das Nações Unidas para o Meio Ambiente (PNUMA) e Organização Mundial de Meteorologia (OMM), em 1988; iii) a ConvençãoQuadro das Nações Unidas sobre Mudanças Climáticas (CMNUCC), criada em Nova lorque, em 1992; iv) o Protocolo de Kioto (inicialmente adotado em dezembro de 1997, em Kyoto, mas assinado e ratificado em 2005); entre outras. Tais ações contribuíram para o avanço no conhecimento cientifico e ajudaram na discussão sobre a variação climática, suas causas e efeitos (Parry, 2007). A variação climática na zona andina reflete-se na dinâmica e sustentabilidade das geleiras e dos ecossistemas desta região. Segundo (Francou, 2013), haverá perda de um grande número desses ecossistemas em curto prazo. Esse processo terá impactos importantes no ciclo hidrológico e na disponibilidade de recursos hídricos para as cidades e povoados, bem como na sustentabilidade de 
atividades produtivas e estruturas sociais (Bates, Kundzewicz, \& Palutikof, 2008); (Immerzeel, Luduvicus, Beek, Marc, \& Bierkens, 2010).

Nos países andinos, as geleiras são fundamentais para a vida e desenvolvimento econômico. A capacidade de armazenar e fornecer água fazem com que se tornem reservas estratégicas de recursos hídricos para a manutenção de atividades socioeconômicas como a agricultura, a mineração, a geração de eletricidade e a indústria, bem como a conservação dos ecossistemas (IPCC, 2012), (IPCC, 2013). No entanto, os efeitos das mudanças climáticas já podem ser vistos nos balanços hídricos e na extensão das geleiras (Francou, B, 2013). Embora cada uma apresente suas próprias características (área, volume e massa), medições feitas nos últimos 150 anos nessas grandes massas de gelo sugerem mudanças significativas no tamanho e no volume, tornando-se uma ameaça aos sistemas físicos, biológicos, sociais e econômicos, afetando a regularização de vazões de bacias hidrográficas e, com isso, o abastecimento de água dos ecossistemas, comunidades e povos dessa região (Francou, Vuille, Wagnon, Mendoza, \& Sicart, 2003).

Segundo Francou \& Vicent (2007), as geleiras andinas cobriam um total de $1.920 \mathrm{~km}^{2}$, distribuídas predominantemente no Peru $(70 \%)$ e na Bolívia $(20 \%)$. Contudo, a partir de 1976, começaram a regredir, com perda entre $35 \%$ e $50 \%$ de sua superfície e volume em 30 anos (Rabatel, Francou, Soruco, Gomez , \& Cáceres, 2012).

Estudos realizados no âmbito dos programas de observação de geleiras tropicais (GREAT-ICE), criados pelo Instituto de Pesquisa para 0 Desenvolvimento (IRD) e seus parceiros andinos na Bolívia, Peru e o Equador, mostraram que as 10 geleiras monitoradas nesses países estão sofrendo derretimento e variação nos volumes de água que drenam para as saídas das bacias que as contêm. $O$ exemplo mais evidente sobre o impacto das mudanças climáticas atuais nas geleiras é o de Chacaltaya, na Bolívia (Figura 1). Essa geleira praticamente desapareceu e apresentou um derretimento acentuado na década de 1980 (Francou, Vuille, Wagnon, Mendoza, \& Sicart, 2003). Além disso, salienta-se a preocupação quanto à perda de massa das geleiras localizadas na Cordilheira Real e Apolobamba, cujos percentuais foram de $55 \%$ e $37 \%$, respectivamente (Francou, Ramirez, Cáceres, \& Mendoza, 2000). 

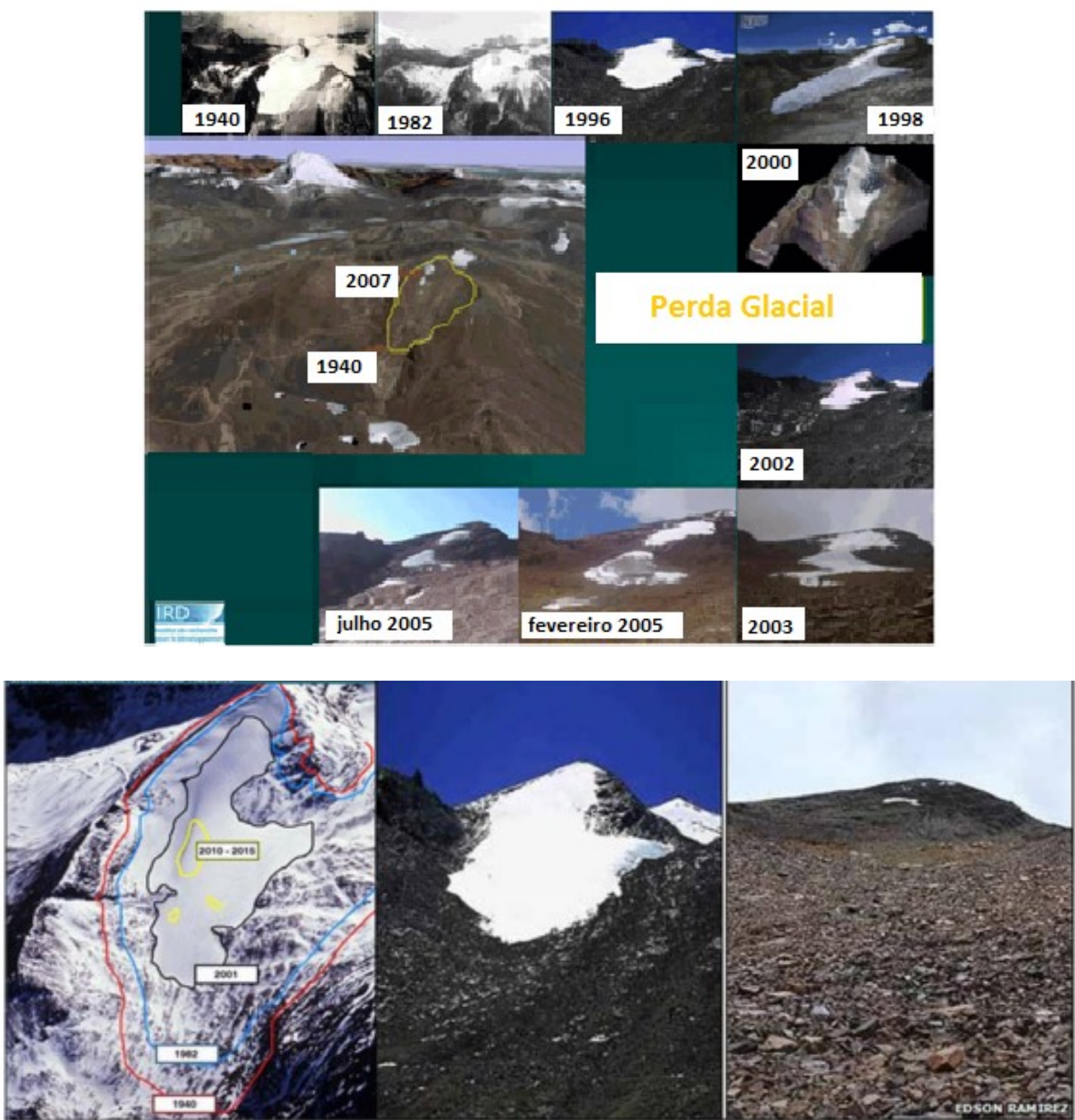

Figura 1. Perda glacial do Chacaltaya (Bolívia). Fonte: (Ramirez, Francou, Cadier, \& Soruco, 2010).

O GREAT-ICE (Laboratório Misto Internacional de Observação dos Glaciares Tropicais) também observou a aceleração no derretimento das geleiras que estão sendo, até hoje, monitoradas no Equador (Antisana), Peru (Broggi, Cajap, Pastoruri, Uruashraju e Yanamarey) e Bolívia (Chacaltaya, Charquini e Zongo). De acordo com a Figura 2, observa-se o decaimento na extensão das geleiras e diminuição das mesmas durante os anos 70 e início da década de 80. 


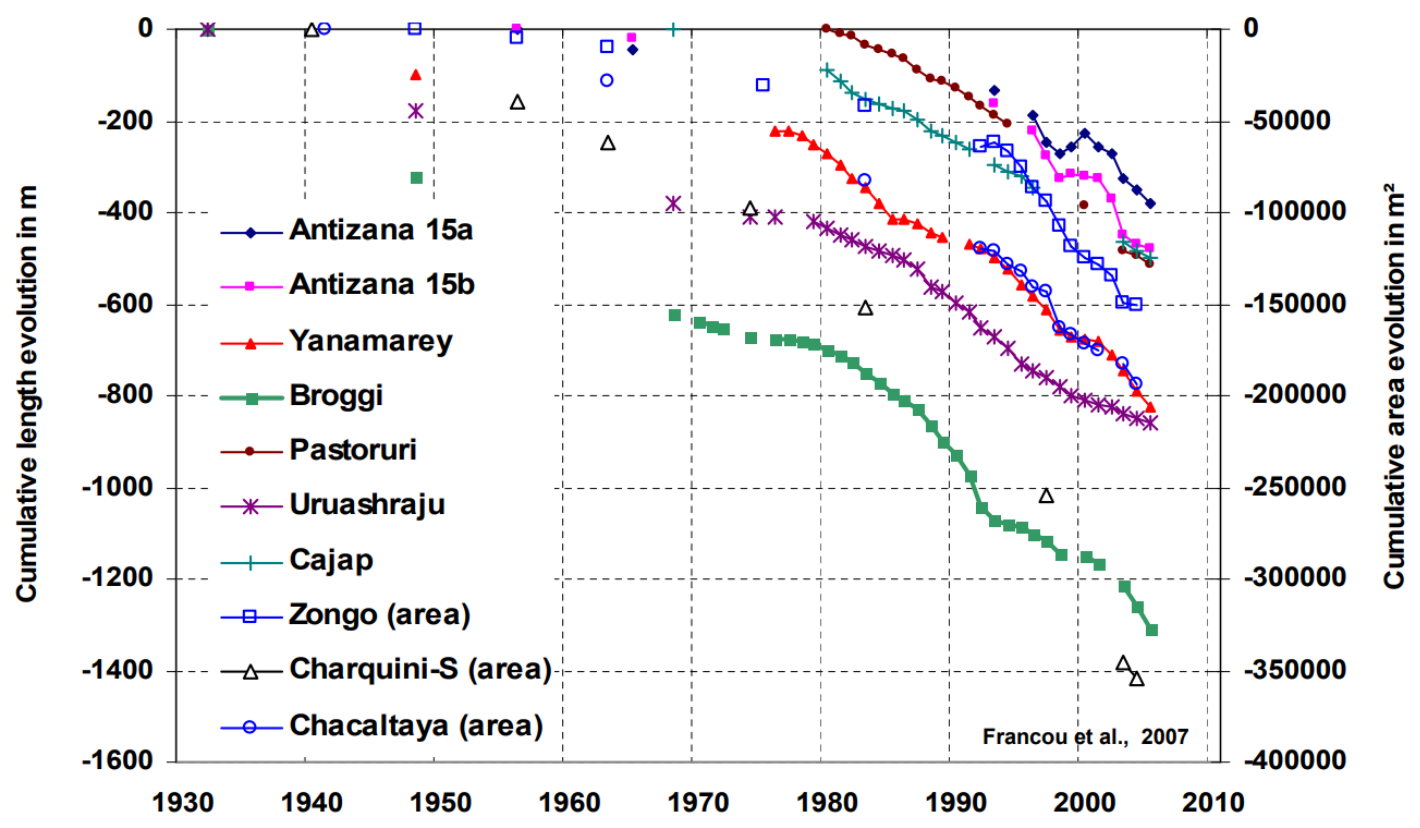

Figura 2. Dados evolutivos referentes à área e comprimento de 10 geleiras monitoradas nos Andes Centrais entre 1930 e 2007 (Fonte: Francou \& Vicent, 2007).

No Peru, estudos mais detalhados conduzidos pelo Instituto de Pesquisa para o Desenvolvimento (IRD, 2009); Servicio Nacional de Meterología e Hidrología del Perú (2009) e pela Agência Nacional de Água (ANA, 2009), mostram que entre 1980 e 2006, o país perdeu $22 \%$ da superfície de suas geleiras, o que equivale à água consumida pela cidade de Lima em 10 anos. Segundo os autores, o local mais afetado é a Cordilheira Blanca, situada na

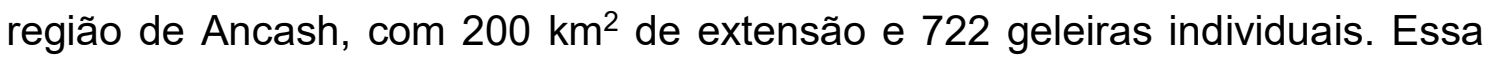
cordilheira foi a mais afetada, com a perda de 145 pequenas geleiras e o derretimento de geleiras maiores, tais como Broggi, Cajap, Coropuna, Pastoruri, Salkantay, Uruashraju, Yanamarey.

No Equador, por sua vez, conforme dados apontados pelo IRD e o cadastro nacional de geleiras do Instituto Nacional de Meteorologia e Hidrologia (INAMHI), em 1997 e 2006, respectivamente existiam sete geleiras cobrindo os maiores picos/vulcões desse país: Chimborazo (6.310 m), Cotopaxi (5.897 m), Antisana (5.704 m), Cayambe $(5.790 \mathrm{~m})$, El Altar $(5.319 \mathrm{~m})$, Los Ilinizas $(5.248 \mathrm{~m}) \mathrm{e}$ Carihuairazo $(5.110 \mathrm{~m})$. A estimativa das coberturas de gelo para os anos de 1997 e 2011 foram, respectivamente, 60 e 50 km² (Cáceres, 2010). Tais geleiras 
perderam entre 30 e 50\% de sua superfície entre 2000 e 2016 (Figura 3). Ressalta-se as perdas registradas nas geleiras situadas no Peru, Bolívia e Colômbia (Francou, Ramirez, Cáceres, \& Mendoza, 2000).

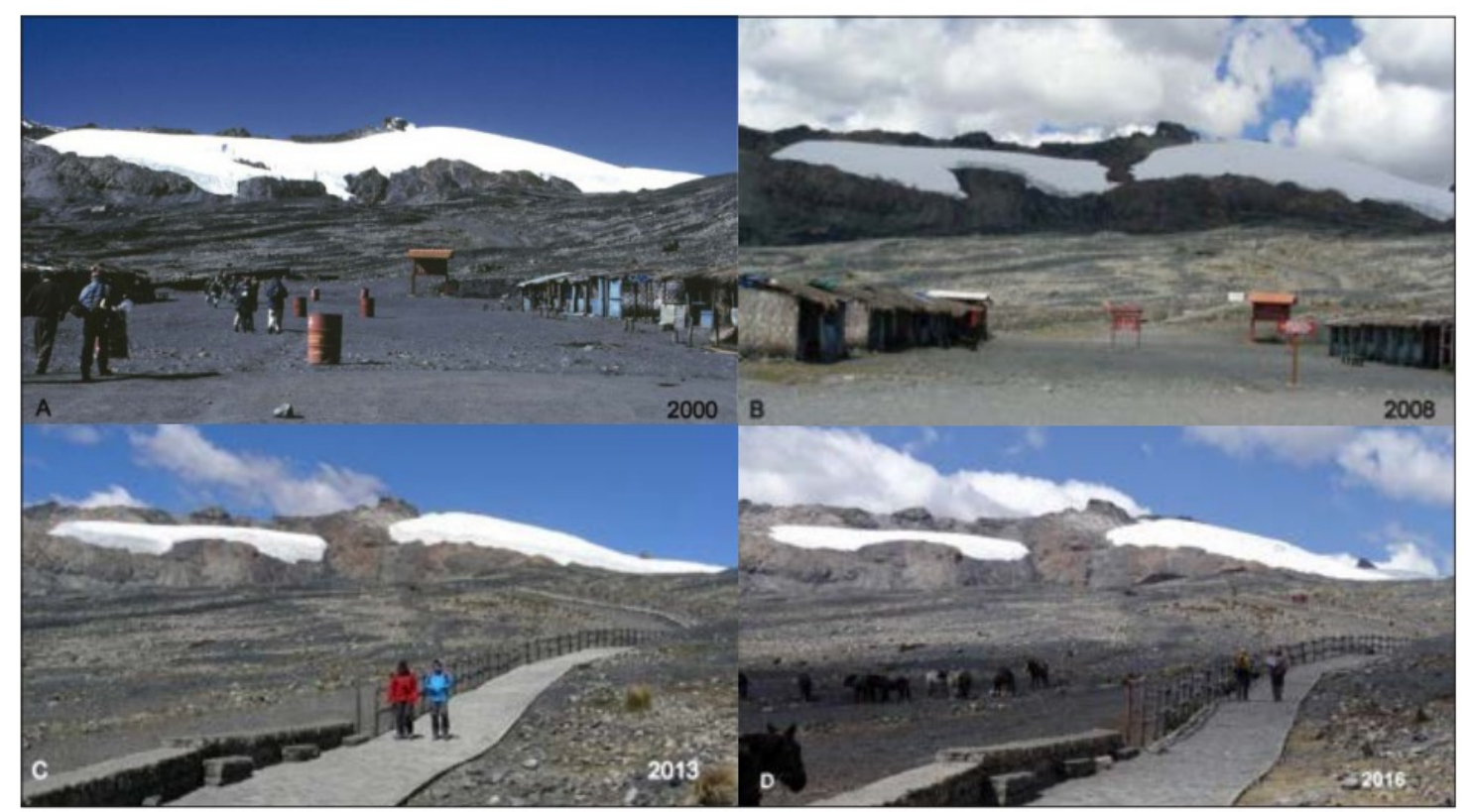

Figura 3. Perda das superfícies da geleira Pastoruri, entre 2000 e 2016. Cordilheira Blanca (Peru). (Fonte: Silverio \& Jaquet, 2017).

La Frenierre (2014) avaliou a evolução da parte nordeste da geleira do Chimborazo, mediante o uso de sensoriamento remoto, registros hidrológicos históricos, análise de dados climáticos e entrevistas às famílias agricultoras. Os resultados obtidos pelo autor mostraram uma perda glacial de $21 \% \pm 9 \%$ entre 1986 e 2013 (Figura 4), refletindo também em perdas de vazão nas bacias glaciais locais. No entanto, salienta-se que a contribuição da geleira para as bacias glaciais é de apenas $5 \%$ da descarga total. O restante, $95 \%$, segundo o autor, seria parte do escoamento superficial e subterrâneo, mas, é preciso fazer uma pesquisa mais aprofundada para estimar as porcentagens desses parâmetros.

Os registros históricos dos dados de precipitação e temperatura no Chimborazo documentaram uma tendência de aquecimento local de $0,11^{\circ} \mathrm{C}$ por década, desde 1986, o que afeta os agricultores locais no sentido da diminuição das precipitações, das vazões dos rios e, consequentemente, da diminuição dos recursos hídricos e das vazões para irrigação. Este fato já está sendo sentido 
por quase todas as pessoas na região. Nestas áreas o autor considerou que a mudança climática já está afetando a sobrevivência e os meios de subsistência agrários.

No Cotopaxi, análises realizadas através de uma restituição aerofotogramétrica de 18 fotografias (em duas linhas de voo que cobriram a geleira), de 1956, 1963 e 2006, estabeleceram que a perda média da geleira no período 1976-1997 correspondeu a 31\% (Cáceres, Ramirez , Francou, Eissen, \& Taupin , 2004) (Figura 5). Já no Antisana, estudos anuais, realizados pelo IRD, INAMHI e EMAAP-Q mostram que a geleira regrediu consideravelmente nos últimos 50 anos. As perdas de gelo atingem entre 6 e 8 m/ano e podem comprometer os fluxos de água dos rios e os volumes de reservatórios que abastecem a cidade de Quito. (Cáceres, 2010).

a)

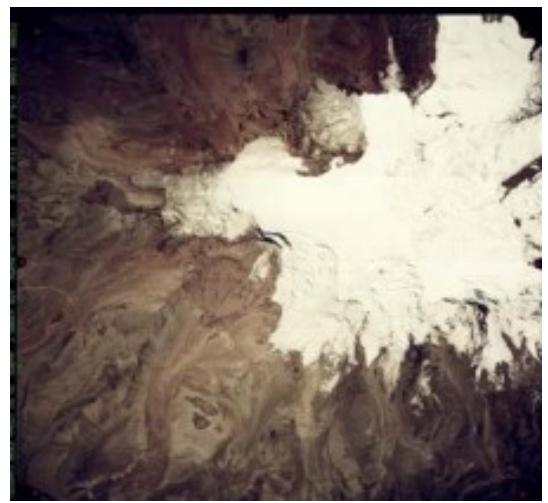

b)

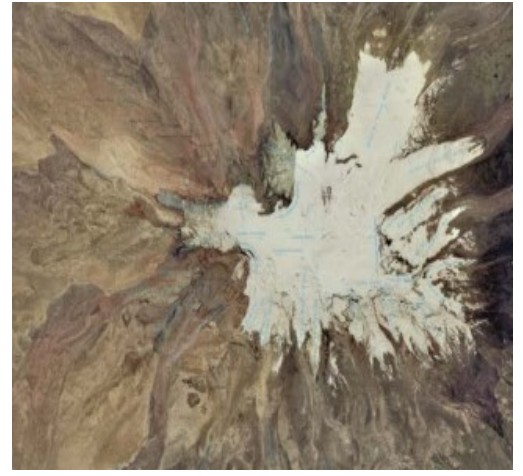

c)
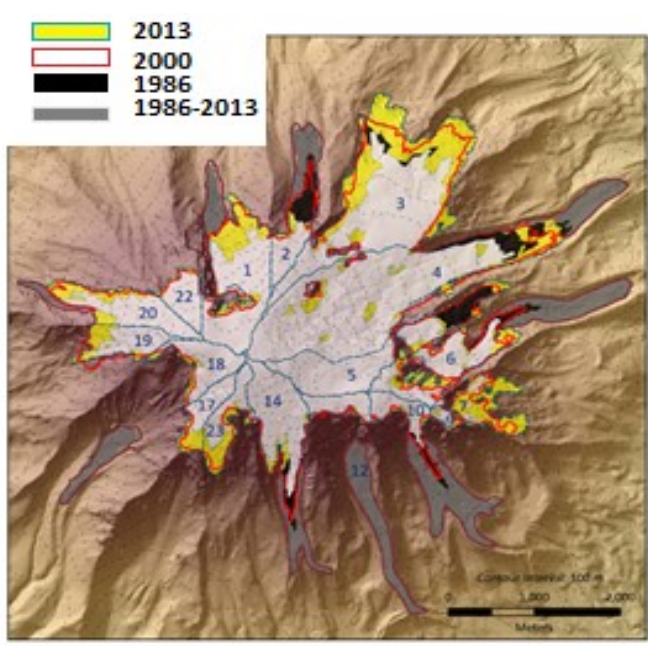

Figura 4. Perda glacial do Chimborazo. a) 1962, b)1997, c) 1986-2013. (Fonte: Cáceres (2010); La Frenierre (2014)). 
Segundo os pesquisadores do (GREAT-ICE), a perda global das geleiras é um processo climático natural, no entanto, a atividade antrópica tem contribuído para acelerar essa dinâmica, comprometendo a segurança hídrica. As perdas glaciais podem afetar as zonas de alta montanha, a recarga de rios, lagos e águas subterrâneas (Bernex \& Tejada, 2010), além de comprometer a segurança hídrica de capitais provinciais como Quito, Riobamba, Latacunga, Ambato. Podendo também afetar a agricultura, uma vez que as culturas andinas podem enfrentar um déficit hídrico, o que causaria a expansão da fronteira agrícola (agricultura extensiva e pastagem) e a transformação de zonas húmidas em zonas agrícolas; imposição de desenvolvimento agrícola e esquemas domésticos de pecuária que não levam em conta as limitações ecológicas do meio ambiente.

Assim também a diminuição do volume dos recursos hídricos aumentará os custos de captação e tratamento da água, além de restringir a expansão da cobertura das redes de abastecimento da água para as regiões rurais. No âmbito social, a crescente pressão sobre os recursos hídricos aumentará os conflitos entre usuários e os interesses econômicos. 
b)

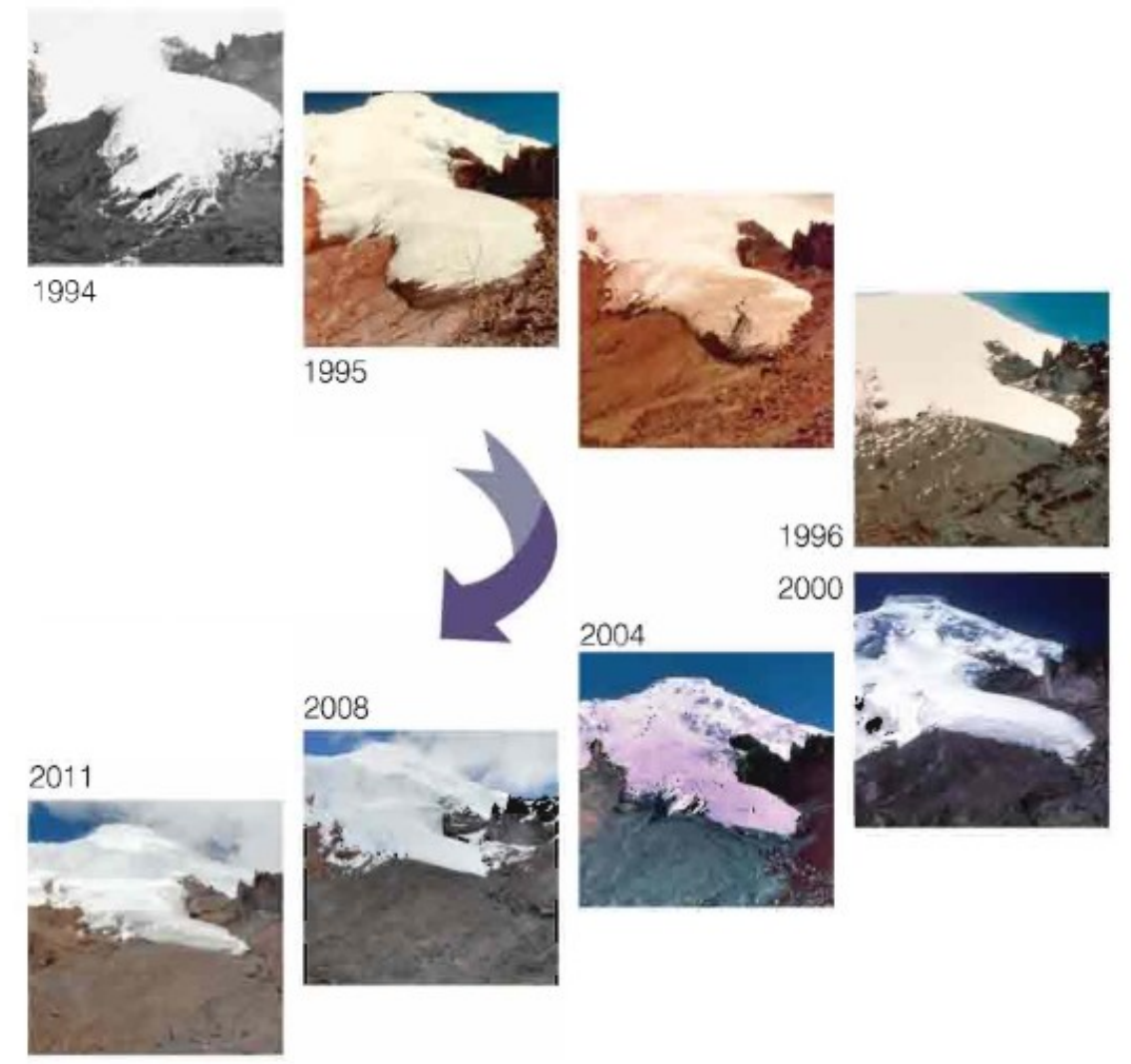

a)
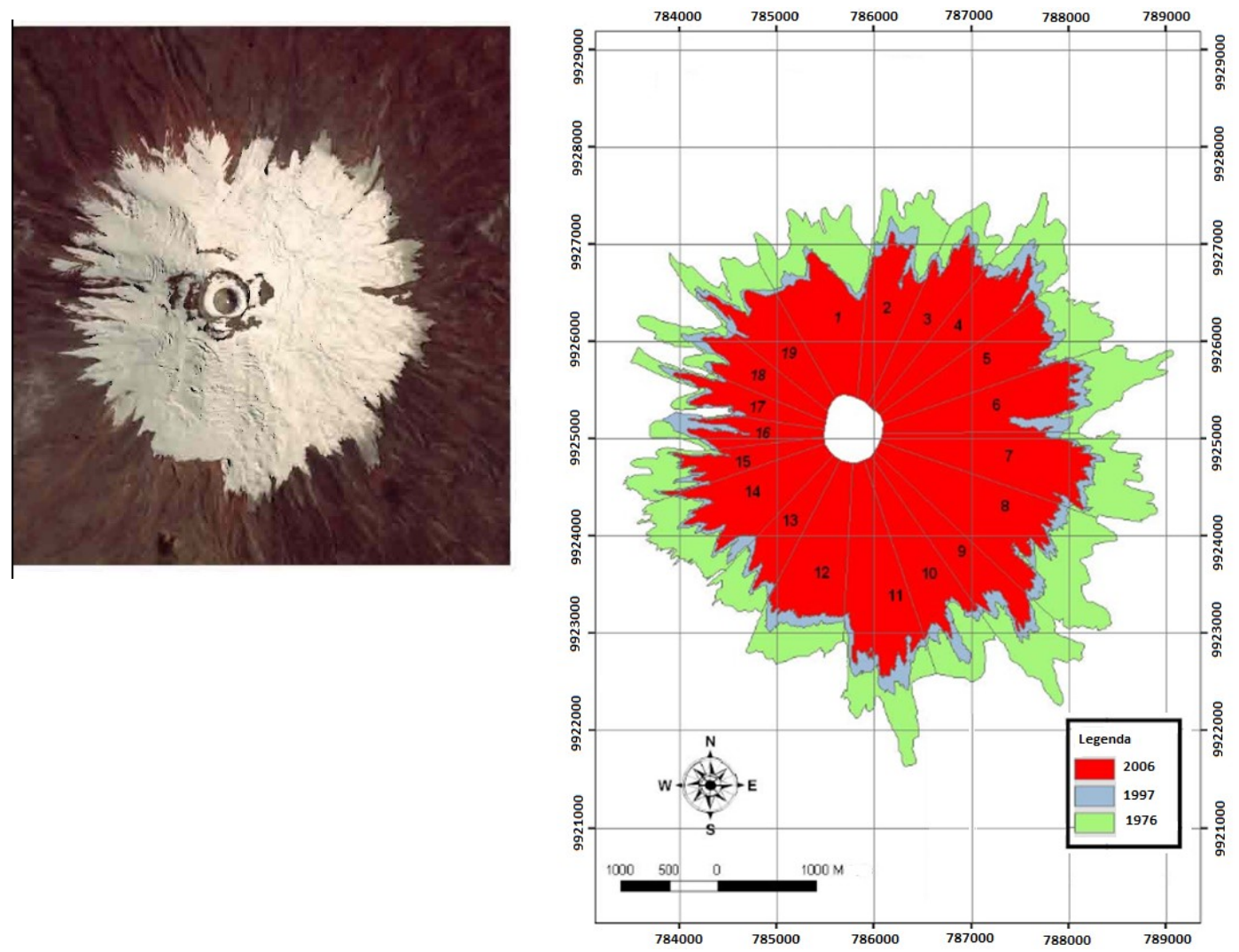

Figura 5.Perda glacial em alguns vulcões no Equador: a) Cotopaxi; b) Antisana. (Fonte: Cáceres, 2010) 


\subsection{Principais conceitos, elementos e estudos de caso para a Gestão integrada dos recursos hídricos (GIRH).}

Este item abordará conceitos importantes, bem com as diferenças entre gerenciamento, governança e gestão integrada de recursos hídricos.

O Gerenciamento de Recursos Hídricos (GRH) é o conjunto de ações que permitem materializar e/ou promover atividades analíticas de coordenação e implementação de projetos destinados à regulação do uso e ao aproveitamento dos recursos hídricos, de acordo com os princípios estabelecidos pela política da água. O gerenciamento da água é constituído pelos seguintes elementos: i) Política da Água; e ii) Plano Diretor (Pilar, 2012).

A governança, por sua vez, refere-se aos sistemas políticos, sociais, medidas econômicas e administrativas, implementados para desenvolver e gerenciar os recursos hídricos e fornecer serviços públicos baseados nos diferentes níveis da sociedade (GWP, 2002); (Rogers \& Hall, 2003). Para que a governabilidade alcance seus objetivos, é necessário que o Estado exerça o papel de regulador de modo a garantir o desenvolvimento econômico e a proteção ambiental de uma nação (Osorno, 2003).

O conceito de Gestão Integrada de Recursos Hídricos (GIRH) foi debatido por muitos anos e não há uma definição única para este termo. No entanto, propõe-se que GIRH corresponda a uma proposta de gerenciamento das águas considerando os aspectos econômicos, sociais e ambientais, com os quais o modelo de gestão pode enfrentar os diferentes problemas associados ao recurso hídrico (Bauer, 2004).

Segundo a Associação Mundial de Água (GWP, 2002) a GIRH é um processo que promove o gerenciamento coordenado dos recursos hídricos (superficiais e subterrâneos), a fim de maximizar o bem-estar social e o equilíbrio econômico resultante, de forma equitativa, sem comprometer a sustentabilidade dos sistemas vitais. A abordagem integrada permite a gestão dos recursos hídricos em todos os setores e grupos de interesse e em diferentes escalas, locais e regionais. Enfatiza-se a participação em processos nacionais para a implementação de leis e políticas, estabelecendo uma boa governança e criando acordos normativos e institucionais efetivos que permitam decisões mais justas e sustentáveis. Ferramentas como avaliações sociais e ambientais, instrumentos 
econômicos e sistemas de informação e monitoramento apoiam essa abordagem (GWP, 2009).

O conceito de $\mathrm{GIRH}$, ao contrário da gestão tradicional dos recursos hídricos, envolve o gerenciamento da oferta e da demanda de água e a governança do processo. Portanto, há uma integração considerada em duas categorias básicas: o sistema natural, com sua importância crítica para a qualidade e a disponibilidade de recurso e o sistema humano, que determina fundamentalmente o uso e o aproveitamento do recurso superficial e subterrâneo (Osorno, 2003).

Por outro lado, o Banco Interamericano de Desenvolvimento (BID) menciona que a GIRH envolve a tomada de decisões e a alocação dos recursos hídricos para os diversos usos, de modo a atender às necessidades de diferentes usuários e partes interessadas. De acordo com este estudo, a GIRH abrange águas superficiais e subterrâneas de forma qualitativa, quantitativa e ecológica, a partir de uma perspectiva multidisciplinar e focada nas necessidades e exigências da sociedade em relação à água (Dourojeanni, 2002).

O recurso hídrico é um fator fundamental para o desenvolvimento de diversas atividades econômicas como: agricultura, indústria, turismo, produção de energia, assim como para o bem-estar e a saúde humana. Seu valor não permite uma fácil avaliação econômica, no entanto, seu valor ecológico e, em muitas religiões e culturas, seu valor simbólico são inestimáveis. Mesmo devido aos conflitos sobre esse recurso, pode-se afirmar que haja até um valor e componente emocional (Llamas, 2007).

Durante as Conferências Internacionais das Nações Unidas sobre Meio Ambiente e Desenvolvimento (CNUMAD), realizadas em Mar del Plata (1977) e em Dublin (1992), definiram-se conceitos e princípios, além de marcar o início de atividades globais sobre os recursos hídricos. Dentre eles, declarou-se, pela primeira vez, que: "todos os povos, qualquer que seja seu nível de desenvolvimento ou condições econômicas e sociais, têm direito à água potável, em quantidade e qualidade, de acordo com suas necessidades básicas". Isto promoveu uma expansão substancial da prestação de serviços básicos para populações pobres, além da ideia básica a respeito da gestão de recursos hídricos. Na conferência realizada em Dublin, em 1992, foram estabelecidos quatro princípios básicos para a gestão das águas, dos quais destaca-se que a 
água doce é um recurso finito e vulnerável, essencial à vida, ao desenvolvimento econômico e ao meio ambiente. Seu uso e aproveitamento devem se basear em uma abordagem participativa, envolvendo os usuários, planejadores e responsáveis pelas decisões em todos os níveis (CEPAL, 1998).

A GIRH é aplicada em diferentes países (Espanha, Estados Unidos, França, Brasil) e está sendo promovida em outros (Austrália, Chile, Colômbia, Equador, Bolívia). Um ponto a ser considerado nos países da Comunidade Andina são as perdas glaciais, consideradas como um fator primordial na GIRH em função dos potenciais impactos na economia, meio ambiente e sociedade (Burlado \& Pellicciotti, 2002).

A partir da segunda metade da década de 90 , o conceito de GIRH começou a ter mais ênfase, uma vez que os gestores começaram a enxergar os recursos superficiais e subterrâneos como um sistema interligado e que a gestão de um afetava a do outro (Winter, 1995); (Woessner, 2000); (Sophocleous, 2002). Assim, as metodologias de avaliação a respeito da conectividade entre os corpos de água superficial e subterrâneo tornaram-se necessárias dentro de uma visão integrada do ciclo hidrológico em uma determinada bacia (Fullgar, Brodie, Sundaram, Hostetler, \& Baker, 2006). Tais metodologias devem considerar os seguintes aspectos: i) estimativa da parcela das águas subterrâneas no cálculo do balanço hídrico; ii) relação entre as variações dos níveis fluviométricos; iii) possível flutuação do nível freático; e iv) eventuais variações sazonais dos parâmetros físico-químicos nas águas. De acordo com (Fullgar, Brodie, Sundaram, Hostetler, \& Baker, 2006), as aplicações de tais metodologias permitem definir as contribuições de um recurso hídrico, superficial ou subterrâneo, em relação ao outro.

A visão integrada dos aspectos relacionados às águas superficiais e subterrâneas inumeráveis vantagens. No entanto, a experiência sobre este tema no mundo não é muito grande, pois implica em uma maior complexidade no planejamento e gerenciamento dos recursos hídricos, além de uma formação em hidrogeologia por parte dos gestores, tomadores de decisão e políticos. Além disso, são necessários outros requisitos que incluem a determinação do uso do recurso e a sua poluição, além do estabelecimento de prioridades para o desenvolvimento econômico (GWP, 2002). 
No entanto, um exemplo de modelo de GIRH, como o desenvolvido na cidade de Madri, Espanha, mostra a aplicação de estratégias para a gestão dos recursos hídricos frente às mudanças climáticas, abrangendo a participação do Estado, gestores e usuários. As ferramentas técnicas usadas neste modelo de gestão para tomada de decisão incluíram os modelos matemáticos (López \& Camacho, 2001). Segundo (Pinto, Gili, \& Velasco, 2010), a integração dessas estratégias minimizou os impactos negativos e maximizou aqueles de cunho social, econômico e ambiental da água.

A GIRH adotada em Madri foi implantada em função dos diversos problemas que a cidade estava enfrentando, do quais citam-se: i) a falta de informação ou informação imprecisa sobre a origem, dinâmica, quantidade e qualidade das águas subterrâneas e superficiais; ii) redução de vazões e escassez de água, principalmente em períodos de seca; iii) falta de manutenção dos sistemas de abastecimento, distribuição e saneamento; iv) outorgas distribuídas sem controle, sobretudo para as classes sociais com mais recursos econômicos; vi) polarização social a partir da distribuição desigual da água e das outorgas (Pinto, Gili, \& Velasco, 2010).

Esses problemas foram diminuindo devido à mudança de visão por parte das autoridades, dos técnicos e dos usuários de água em relação ao entendimento da dinâmica de fluxo, quantidade, qualidade e gestão dos recursos hídricos (López \& Camacho, 2001). Isto se deve ao fato de que Madri criou e melhorou a infraestrutura para o armazenamento e a distribuição das águas subterrâneas (Canal de Isabel II), bem como, incorporou ao sistema antigo as águas superficiais dos rios das bacias vizinhas (por exemplo: rio Lozoya). Ademais, a cidade foi gradualmente incorporando um cadastro de dados provenientes dos diferentes parâmetros que envolvem o $\mathrm{GIRH}$, tais como: i) determinação das unidades hidrológicas; ii) reconhecimento dos diferentes usuários e dos setores que usam ou até exploram a água de forma excessiva; iii) formulação de leis e Políticas Públicas, estabelecimento de governança e criação de acordos normativos e institucionais para a tomada de decisão (López \& Camacho, 2001).

Nos Estados Unidos, (Fredericks, Labadie, \& Altenhofen, 1998) desenvolveram um sistema informatizado com o intuito de avaliar as estratégias e os melhores cenários para alocação dos recursos hídricos superficiais e 
subterrâneos na Bacia do Rio South Plate, no Estado de Colorado. Os autores, na ocasião, criaram bases de dados com informações sobre precipitações, cadastro de nascentes e rios, níveis d'água, flutuações das vazões superficiais e subterrâneas, usos, demandas e legislações, local e estadual, de recursos hídricos. Estas informações foram compiladas em um software para ajudar os técnicos na modelagem e planejamento de alocação dos recursos hídricos superficiais e subterrâneos em diferentes períodos do ano (principalmente seca e estiagem). Assim, as simulações realizadas nos períodos de chuva preveem que os excedentes de água, decorrentes das precipitações, deveriam ser armazenados em poços (localizados à montante do rio) para serem aproveitados nos períodos de seca. Durante a estiagem, o excesso hídrico armazenado pode ser distribuído, junto com as águas superficiais ou subterrâneas, levando em consideração as prioridades e os custos até atender a demanda.

Em relação aos países da Comunidade Andina, profundas alterações na estrutura legal e administrativa para a gestão dos recursos hídricos na região foram realizadas ao longo do tempo. A mudança de uma estrutura estatal tradicional, previamente organizada baseada nos setores da atividade socioeconômica, para outra cujo enfoque se concentra nos objetivos ambientais, desenvolvimento econômico e numa forte descentralização e fortalecimento de esquemas regionais ocorreu na Colômbia (Madroñero, 2006); Equador (Vásquez, 2008); (Senplades, 2012), Peru (Barrientos, 2011) e Bolívia (Alurralde, Salon, \& Orellana, 2003); (Mondaca, 2011). No entanto, apesar de tais avanços, existem ainda alguns fatores comuns na comunidade andina que ainda não permitem o gerenciamento adequado da água, dos quais destacam-se: i) fraqueza e ausência de uma hierarquia institucional; ii) descentralização realizada sem gradualismo, suporte técnico e regulação; iii) cadastros de corpos d'água superficiais e subterrâneos inexistentes ou incompletos; iv) descentralização e falta de compartilhamento dos dados (outorgas, ofertas e demandas de água) entre as entidades governamentais; e v) ineficiência na aplicação de ferramentas analíticas e informatizadas, com enfoque na abordagem da gestão integral, para o governo, administração e medição do valor de recurso de água (Ojeda, 2000).

Outros fatores, como o crescimento populacional desordenado, outorgas de água concedidas sem critérios técnicos e as mudanças climáticas, também 
exercem um forte impacto nos recursos hídricos. A estes fatores somam-se, também, a demanda de infraestrutura (canais de irrigação, hidrelétricas) para sustentar a produção de alimentos, gerar energia e fornecer bens e serviços. Embora a construção de sistemas de irrigação, hidrelétricas e abastecimento de água às residências, indústria e turismo sejam essenciais para o progresso de uma nação, eles também geram grandes mudanças nos regimes hidrológicos, nos ecossistemas e na aparência da maioria dos rios, lagos e aquíferos. À medida que a escassez de água aumenta e a variabilidade hidrológica se torna maior, a população enfrenta uma série de mudanças causadas pelo desenvolvimento.

Então o desafio para os governos da comunidade andina e os administradores de recursos hídricos é harmonizar o desenvolvimento e a sustentabilidade. Isso significa encontrar maneiras mais inteligentes de usar e gerenciar recursos hídricos e encontrar respostas adequadas às circunstâncias de cada bacia específica. Isto não será feito enquanto não sejam abordadas questões estruturais (incluindo aquisição de dados, infraestrutura e operações e manutenção) e questões institucionais (políticas, leis, acordos normativos e institucionais para a tomada de decisão e preços). Estas questões estão ligadas entre si e dependem de cada país.

No Equador, os recursos hídricos estão sujeitos a uma pressão que é função da demanda de água para satisfazer as múltiplas necessidades que dependem dela (agricultura, eletricidade, abastecimento urbano e rural, comércio). Muitas instituições nacionais públicas e privadas têm a ver com este recurso cada vez mais escasso. A falta de comunicação e interação técnica entre estas instituições prejudica sua ação para servir as comunidades e os habitantes das comunidades e províncias, que em muitos casos compartilham e disputam pela água.

A gestão dos recursos hídricos ainda é incipiente e fraca, com ausência de cadastros com informações técnicas e específicas dos corpos de água superficiais e subterrâneos; sem considerações ambientais e quase sem qualquer atividade normativa e regulatória para sua manipulação. Atualmente é uma gestão de serviços concentrada em agências do governo central, com desenvolvimento de agências governamentais locais (com pouca informação e pouco pessoal técnico). Pouco desenvolvimento de políticas e planejamento 
para o gerenciamento da água e seus serviços. Entidades de desenvolvimento regional, especializadas em água potável e saneamento, em irrigação e em energia hidroelétrica, dependentes do governo central, dedicados principalmente à construção de infraestrutura.

Essas particularidades na gestão, juntamente com uma estrutura orgânica e funcional deficiente, causam os seguintes problemas: i) alteração perceptível no regime de escoamento em algumas bacias hidrográficas, com aprofundamento de problemas causados por inundações e agravamento dos processos de erosão; (ii) poluição generalizada de rios e outros corpos de água devido a águas residuais, causada por atividades urbanas e de comércio; (iii) serviços de eletricidade, irrigação, água potável e saneamento altamente subsidiados, subfinanciados e ineficientes; e (iv) obras hidráulicas para irrigação incompletas.

Pelo exposto, a gestão adequada e sustentável da água é particularmente importante no Equador, porque as desigualdades sociais e econômicas entre os diferentes atores estão intimamente ligadas ao acesso à água. Além disso, o país necessita de informações técnicas e cadastros dos pontos de água, determinação das características quantitativas e qualitativas para serem administradas de acordo a seus usos na agricultura, energia elétrica e abastecimento público.

\subsection{Políticas, normativas e instituições envolvidas na gestão dos recursos hídricos no Equador.}

A estrutura legal é importante e deve ser observada para que os recursos hídricos sejam utilizados e distribuídos de forma racional e equitativa, com a participação de organizações de usuários e instituições públicas, que desenvolvam as pautas e ações assertivas e sustentáveis nos territórios. Por outro lado, o ordenamento legislativo também deve ser adequado à realidade local para conseguir a efetividade na distribuição e no planejamento do recurso hídrico.

Uma revisão legal deve iniciar com a análise dos ordenamentos vigentes a partir do texto constitucional e seus desdobramentos, para posteriormente obter uma visão sistemática de todo o arcabouço. 
A Constituição Equatoriana, no seu Artigo 411 (Equador, 2018), descreve os princípios que regem a questão da gestão integrada dos recursos hídricos. Entre eles, o mais importante diz respeito à proteção, controle, regulamentação e distribuição equitativa da água no país.

Destaca-se na Constituição a necessidade da criação e aprovação da Lei Orgânica de Recursos Hídricos e a Lei de Regulação, Usos, Aproveitamento e Controle dos mesmos. Essas leis, aprovadas em 2014, ditam as regras gerais, as resoluções, as permissões de uso (atuais e futuras) e as portarias que os diversos órgãos do Estado devem cumprir e regulamentar. Cabe aos órgãos do Estado, tais como, SENAGUA (Autoridade única e reitora), Conselho Intercultural e Plurinacional da água, Ministérios (Agricultura, Saúde e Ambiente) e Governos Autónomos Descentralizados (GAD que representa a prefeitura), definir e regular o Sistema Nacional Estratégico da Água (artigos 28 e 29 da Lei). Esse sistema tem como objetivo primordial coordenar o planejamento e a aplicação da política pública de recursos hídricos com os atores sociais ligados à água como se mostra no diagrama a seguir.

É importante assinalar que além das Normas Constitucionais e as Leis acima mencionadas, o Código Orgânico de Autonomia e Descentralização da Organização Territorial (COOTAD), nos artigos 132 e 136, menciona as competências institucionais em relação à gestão de recursos hídricos, garantindo a coordenação entre os diferentes níveis de governo e garantindo a participação dos cidadãos, especialmente de usuários da água potável e de irrigação.

Com base nas disposições constitucionais, a SENAGUA iniciou em 2014 um processo de cadastro de recursos hídricos com o intuito de ter informações atualizadas sobre o estado da água, seus usos e outorgas, assim como estabelecer as pautas gerais para empreender a gestão de recursos hídricos, desenvolvendo as normativas referentes à conformação dos Conselhos de Bacia (artigos 25, 26, 27 e 28) e planejamento hídrico. Desta forma, construir e fortalecer o Sistema Nacional Estratégico da Água, como mostra o diagrama a seguir. 
Sistema Nacional Estratégico da Água

${ }^{1}$ Constituição (2008); ${ }^{2}$ Código Orgânico de Organização Territorial (2013); ${ }^{3}$ Lei Orgânica de Recursos Hídricos, usos e aproveitamento da água (2014); ${ }^{4}$ Lei de Regulação de Recursos Hídricos (2015)

\section{Coordenação da administração}

Secretaria Nacional da Água

(SENAGUA)

Agência de Controle de Água

(ARCA)

Empresa Pública da Água (EPA)

O Conselho Intercultural e

Plurinacional da água

\section{Ministérios competentes}

Agricultura, Ambiente, Saúde.

\section{Coordenação local}

Governos Autônomos

Descentralizados (GADs)

Demarcações Hidrográficas (DH)

adstritas à SENAGUA.

Prefeituras provinciais.

\section{Órgãos de consulta}

Conselho de bacia

Comitê de gestão de sub-bacia
Autoridade Única da Água, encarregada do planejamento de recursos hídricos com base no Plano Nacional e Planos Integrados de

- Gestão, considerando a bacia hidrográfica como a unidade territorial. Para fins de planejamento e gerenciamento de água ou delimitação de águas superficiais e subterrâneas, os recursos hídricos podem ser agrupados e constituir as Demarcações Hidrográficas. Atualmente existem 9 Demarcações Hidrográficas definidas só pelas delimitações superficiais.

$\rightarrow$ ARCA, EPA: Órgãos de direito público, de natureza técnico-administrativa, adjuntos à SENAGUA. O primeiro é o responsável pela regulação e controle da gestão integrada de recursos hídricos (quantidade e qualidade da água) $\left({ }^{4}\right.$ Art. 8). E o segundo responsável pela contratação, administração e supervisão de projetos de infraestrutura hídrica assim como a gestão comercial do recurso.

Órgão com um conjunto de representantes que participam na promoção do conhecimento ancestral sobre propriedades da água natural ( ${ }^{1}$ Art 207; ${ }^{3}$ Art.33). Tem representação com delegados para a conformação do Sistema Nacional Estratégico da água

Instituições com competências relacionadas que controlam principalmente a qualidade da água. Por exemplo, o controle da qualidade da água para consumo humano é realizado pelo Ministério da Saúde, efluentes pelo Ministério do Meio Ambiente e irrigação do Ministério da Agricultura. Cada Ministério tem uma representação com delegados para a conformação do Sistema Nacional Estratégico da água.

Gerenciam o ordenamento territorial das bacias, sub-bacias e micro bacias através de planos e políticas de gestão integrada de recursos hídricos sujeitos ao planejamento da SENAGUA. Os GADs provinciais realizaram os trabalhos de infraestrutura (2Art.132; ${ }^{4}$ Art.37). Os GADs podem ser regionais, provinciais, distritais, municipais, rurais ou indígenas. Possuem competências exclusivas em matéria de áqua (planejamento e execução de obras).

Órgãos colegiados de caráter consultivo, liderados pela SENAGUA e integrados pelos representantes eleitos das organizações de usuários, com a finalidade da participação na formulação, planejamento, avaliação e controle dos recursos hídricos na bacia ( ${ }^{2}$ Art.25). Podendo participar os representantes das universidades e escolas politécnicas $\left({ }^{4} A r t .26\right)$. Os conselhos podem executar os planejamentos Hidrográficos locais ou de Demarcação Hidrográfica.

Organizações em bacias maiores, baseadas principalmente nos usuários da zona rural. O principal objetivo é avaliar os requerimentos de infraestrutura. assim como os problemas aerados pelas outoraas de áaua em cada sub-bacia. $\left({ }^{4}\right.$ Art 41.42 e 43$)$. 
Na província de Chimborazo, em meados dos anos 90, os usuários de sistemas de água (irrigação e consumo humano) fizeram as primeiras propostas sobre a gestão dos recursos hídricos. Com essa motivação, eles formaram as Interjuntas de Irrigação e Água Potável (agrupamentos de usuários criados para defender seus direitos frente as organizações encarregadas de administrar a água). A partir dessa visão surgiu o projeto de planejamento e gerenciamento na bacia do rio Chanchán (localizado ao sudoeste da área de estudo). Esse projeto envolveu a caracterização superficial da bacia e os primeiros cadastros dos pontos de captação de água, principalmente para irrigação. Embora esse projeto não tivesse tido continuidade, foi a primeira iniciativa de gestão dos recursos hídricos nas bacias interandinas.

A partir desse momento, as interjuntas, solicitaram por muito tempo a realização de projetos que avaliem integralmente os recursos hídricos na bacia do rio Chambo, uma vez que não tinham uma ideia clara das vazões de outorgas e explotação (ofertas e demandas). Os usuários das interjuntas não contavam com acesso à informação sobre a água, motivo pelo qual realizaram suas atividades de irrigação e abastecimento sem referências técnicas. Em 2008, um conjunto de usuários (reunidos na federação de organizações de usuários Interjuntas Chimborazo), autoridades do GAD, da Secretaria da Água, dos Ministérios, e da Central Equatoriana de Serviços Agrícolas (CESA) realizaram o primeiro processo para a construção de um planejamento de recursos hídricos no município de Riobamba e na sub-bacia do rio Chambo. Neste processo houve a proposta de criação do Comitê de gestão da sub-bacia do rio Chambo. $O$ Comitê realizou um primeiro diagnóstico dos problemas, na intenção de identificar os componentes e representantes institucionais e sociais ligados à gestão da água na bacia. No entanto, alguns aspectos técnicos, como interpretações geológicas, quantificação de recursos hídricos (superficiais e subterrâneos), definição dos possíveis níveis aquíferos, cálculo de vazões dos corpos superficiais, precisaram de aprofundamento e análises mais detalhadas. Em 2010, o Comitê procurou estabelecer suas funções e um organograma institucional, considerando a criação de uma Secretaria Técnica e a legalização do Comitê. Contudo, após a aprovação da Lei de Águas, tal legalização não prosperou. As ideias dos Conselhos de bacia foram confundidas com a criação 
de Comitês e suas funções, organização administrativa e financeira até agora não são claras.

No que diz respeito à contaminação de águas superficiais e subterrâneas, a lei não faz referência clara e precisa. A SENAGUA avalia o problema e define as penalidades. A avaliação baseia-se no Texto Unificado da Legislação Secundaria, Médio Ambiente (TULAS, 2003), o qual foi criado para a regulamentação da prevenção e do controle da poluição ambiental. Com relação aos recursos hídricos, ele apenas propõe limites admissíveis de qualidade da água, de acordo com seus usos.

Para obter outorgas de uso e aproveitamento da água (Autorização de Implantação de Empreendimento) junto a SENAGUA (nas suas Demarcações Hidrográficas), o interessado deve cumprir o processo de pedido, além das exigências estabelecidas na Lei de Águas e no Regulamento explicitada no Registro Oficial No 483, de 20 de abril de 2015 (Equador, 2015). Assim também deverá indicar o plano geral com a localização do poço, nascente ou corpo de água superficial, descrevendo o uso e a ocupação do solo, o plano de obra (orçamento, perfis construtivos de poços e vazão máxima de exploração), a existência ou não dos corpos de água vizinhos (mas não especifica um raio ou distância máxima com o corpo de água vizinho) e o parecer técnico emitido pelo órgão competente, de acordo com o aproveitamento e finalidade de uso da água, ou seja, aproveitamento agrícola e aquicultura (MAGAP), mineiro (ARCOM), hidroelétrico (MEER) e água engarrafada (ARCSA).

Cabe mencionar que os mecanismos legais existentes estabelecem alguns instrumentos de gestão e estrutura. No entanto, os planos de bacias hidrográficas ainda são incompletos. Isto se deve principalmente à falta de informações geológicas e hidrogeológicas (cadastro de dados das principais formações geológicas, parâmetros hidrogeológicos) nas bacias, assim como a falta de dados e estudos sobre a quantificação de recursos hídricos superficiais e subterrâneos, dos usos da água e dos critérios para alocação integrada de recursos hídricos. A esses problemas, deve-se acrescentar o fato de que não existe uma fiscalização no sentido de coibir condutas e atividades que comprometam a qualidade das águas superficiais e subterrâneas, posto que as informações, por exemplo, o monitoramento da qualidade desses corpos é pouco significativo ou inexistente. 
A Lei de Recursos Hídricos de 2014 tenta transformar o quadro regulatório e institucional do setor de águas no Equador numa regulação que tenha uma visão na gestão integrada de recursos hídricos. Esta mudança tenta ser significativa sem priorizar somente o uso agrícola do recurso hídrico. No entanto, da análise do atual quadro normativo e institucional, é claro que a burocracia do estado equatoriano consolidou seu poder formal na gestão da água e estabeleceu um roteiro para uma nova cultura da água no país, com base nos princípios dos direitos formais, o reconhecimento do valor econômico de recursos hídricos e a governança multissetorial. Esta nova política da água tinha sido moldada em parte para uma cultura tecnocrática, que se baseia em uma longa história de visão da água na engenharia.

A descentralização e participação dos usuários nos planos de gestão das bacias hidrográficas, na prática, é afetada pela confusão dos termos: Conselhos de bacia, Comitês de bacia, Comitê de gestão de sub-bacia e suas conformações e atribuições. Os poucos Comitês conformados foram temporais (existindo no tempo que um projeto especifico com recursos externos dura, entre 1 e 2 anos) e os dados levantados nesses projetos não estão disponíveis ou têm problemas de acessibilidade.

A Outorga e Direitos de Uso de recursos hídricos se dá com base em relatórios técnicos ambíguos e alguns sem constatação de campo. Atualmente, essas informações incompletas e desorganizadas formam parte dos cadastros de outorga de cada uma das Demarcações Hidrográficas (entes representantes da SENAGUA nas províncias).

\subsection{Políticas, normativas e instituições envolvidas na gestão de recursos hídricos no Brasil.}

A institucionalização da gestão da água no Brasil começou com a criação da Comissão de Estudos das Forças Hidráulicas, em 1920, como parte do Ministério da Agricultura, Indústria e Comércio. Isso devido à preocupação de garantir o abastecimento de água nos setores produtivos (Magalhães, 2007). No entanto, a primeira iniciativa de ação para a gestão da água no Brasil surgiu com o Código de Águas, em 1934 (Decreto 24643/1934). 
Este código incluiu vários aspectos legais, como: i) a proibição da poluição das águas; ii) possibilidade de pagamento pela utilização de água; iii) prioridade da água para consumo humano; iv) outorgas administrativas para águas públicas; e v) a declaração da água como domínio público estadual ou municipal. No entanto, esse código se concentrou no desenvolvimento do setor hidroelétrico, criando, em 1939, o Conselho Nacional de Água e Energia Elétrica e em 1968, o Departamento Nacional de Água e Energia Elétrica (DNAEE) (Granziera, 2001). A prioridade dada ao setor de energia foi acompanhada por um fortalecimento na agenda nacional do setor de água e saneamento, foi assim que se criou o Departamento Nacional de Obras e Saneamento, em 1971, e as empresas estatais que prestam esses serviços em todos os estados do Brasil.

Nos anos 70, os investimentos governamentais foram priorizados de forma isolada em cada um dos setores e usuários da água, mas tendo ênfase na água potável, saneamento básico e geração de energia hidrelétrica. Os Investimentos governamentais isolados geraram conflitos sobre o uso da água entre diferentes usuários nos diferentes setores (Borsoni \& Torres, 1997).

Em 1973, foi criado o Ministério do Meio Ambiente, o mesmo que se dedicou ao controle da poluição da água, sem estabelecer contato com o DNAEE, instituição criada em 1976 para o planejamento das águas federais do país.

$\mathrm{Na}$ área de saneamento e água potável, foi assinado um acordo entre o Ministério de Minas e o governo do Estado de São Paulo, com o objetivo especifico do desenvolvimento de obras nas bacias Tietê e Cubatão (Porto \& La Laina Porto, 2008). Este acordo foi considerado como a primeira experiência de gestão da água e deu origem ao primeiro órgão institucional relacionado às bacias hidrográficas.

Em 1978, foi criada a Comissão Especial de Estudos Integrados de Bacias Hidrográficas (CEEIBH). Os objetivos desta organização foram: i) a classificação das águas do país; ii) o desenvolvimento do estudo sobre o uso racional das águas federais, e ii) supervisionar a gestão da água e a gestão ambiental em todo o país.

Ao mesmo tempo, surgiram dez comitês de bacias executivas. Esses comitês constituíram os órgãos consultivos (sem apoio legal), mas importantes em relação à gestão de recursos hídricos nas bacias. Vale ressaltar que a 
conformação desses comitês tinha serias limitações, como por exemplo, membros que eram unicamente funcionários públicos e na estrutura administrativa e financeira praticamente que não existiu.

Com a Constituição Federal de 1988 (Brasil, 1988), a gestão de recursos hídricos sofre mudanças fundamentais, posto que ficou estabelecido que as águas superficiais e subterrâneas são bens da União ou dos Estados, ficou sob a tutela dos Estados a gestão das águas subterrâneas, enquanto que a das águas superficiais é compartilhada entre a União e os Estados (Art. 26, Inc. I e Art.20, Inc. III). No entanto, do ponto de vista institucional houve uma enorme controvérsia no que se refere às águas subterrâneas. Este recurso hídrico, de acordo com esta constituição é de domínio estadual. Entretanto, os aquíferos transcendem os limites estaduais e até nacionais, pelo que a aplicação dos limites institucionais se tornou um problema.

Posteriormente, com a aprovação da Lei nº 9.433 em 8 de janeiro de 1997 (Brasil, 1997) a água passa à condição de bem de domínio público, dotada de valor econômico. Com esta lei, a bacia hidrográfica, definida tradicionalmente como área de captação natural da água da precipitação que faz convergir os escoamentos para um único ponto de saída (Tucci, 2003), ganha uma definição alternativa, passando a ser observada como a unidade de gestão e aplicação da Política Nacional de Recursos Hídricos.

Associado à criação da Lei das Águas, foi promulgada a Lei Federal $\mathrm{n}^{\circ}$ 9.984, em 17 de julho de 2000 (Brasil, 2000). Esta lei cria a Agência Nacional de Águas (autoridade federal responsável por implementar a Política Nacional de Recursos Hídricos, bem como regular o uso das águas de domínio da União). A Política Nacional de Recursos Hídricos (PNRH) foi um passo no sentido de pôr em prática as disposições propostas pela Constituição Federal. A sua importância reside nos seguintes aspectos: i) modernização da gestão da água utilizando padrões e instrumentos implementados em vários países; ii) participação dos usuários e da sociedade civil na gestão, buscando legitimidade e adoção real das políticas (Porto \& La Laina Porto, 2008); iii) tornou prioritário considerar os múltiplos usos da água, reduzindo a importância do setor de energia na gestão do recurso (Borsoni \& Torres, 1997); e iv) analisou e reestruturou os instrumentos de gestão já existentes (planejamento e administração). O planejamento incluiu o plano de bacia hidrográfica, o 
enquadramento dos corpos de água em classes segundo os seus usos preponderantes e o Sistemas de Informação sobre Gestão de Recursos Hídricos (SIGRH). A administração foi direcionada a controlar o uso do recurso hídrico através das outorgas e da cobrança pelo uso da água (Granziera, 2001).

Ao nível local, o PNRH criou os Comitês de bacia hidrográfica. Esses comitês têm as funções básicas de aprovação de planos de água e encargos de uso, determinando o valor de taxas e realizando a intermediação em caso de conflitos entre usuários. Os comitês são constituídos por representantes dos governos federal, estadual e municipal dos usuários e da sociedade civil (Warner, 2005): (Jacobi \& Fracalanza, 2007). No caso das bacias localizadas no Estado de São Paulo, a legislação e estrutura dos Comitês é diferente e bem mais avançada do que o nível federal: há o mesmo número de representantes do governo estadual, governo municipal e representantes da sociedade civil.

\subsection{Análise comparativa dos modelos e instrumentos de GIRH no Equador e no Brasil.}

Brasil e Equador são países com riqueza hídrica. Isto porque possuem uma grande quantidade de rios, dentre os quais destaca-se o Amazonas, posicionando-se como o mais longo e com maior vazão do mundo. Apesar disso, os dois países têm problemas de déficit de água, devido à distribuição desigual do recurso. No Brasil, a região norte que é a menos urbanizada tem $68,5 \%$ do abastecimento de água (Brasil, 2012) e no Equador, o maior potencial de água (88\%) está localizado na Amazônia, que possui apenas o 4\% da população do país (CEPAL, 2015).

Em ambos os países existe disposições e instrumentos voltados para a gestão da água no nível da bacia, mas estes não seguem necessariamente os desenvolvimentos conceituais da gestão integrada do recurso hídrico (Tabela 1).

Como mostrado na tabela 1, é evidente que o Brasil gerou todos os prérequisitos necessários para implementar a $\mathrm{GIRH}$, enquanto no caso equatoriano isso não é tão evidente. Nos dois países, a bacia é a unidade de planejamento, que foi delimitada para gerenciar a água. No Brasil a estrutura de gestão e as ferramentas para a GIRH são descentralizadas e participativas, uma vez que os Comitês de Bacia foram designados legalmente como entidades que direcionam 
as ações a serem realizadas na bacia. Assim também os Comitês têm participação formal e representativa das partes interessadas e da sociedade civil. Também há planos de bacias que devem ser formalmente aprovados pelos Comitês da Bacia e há uma política de orientação para a GIRH ao nível nacional.

No Equador, os Comitês de Bacia não foram formalmente estabelecidos como órgão de gestão e decisão, portanto, não há um mecanismo para a participação dos atores sociais na gestão. Os planos da bacia são obrigatórios e estão incluídos nos planos de ordenamento territorial dos municípios, que definem os usos do solo e da água.

Nos dois países, a implementação de instrumentos econômicos como a taxa de uso da água e a taxa de descargas de águas residuais ainda não está amplamente implementada. Considerando a exceção do Estado de São Paulo, no qual, a GIRH é amplamente implementada e eficiente.

No Equador, os postulados da política da água não foram implementados em ações nas bacias. Os setores de usuários de água, que geralmente têm uma representação política no governo em nível ministerial (água para agricultura, água para energia e outros), não coordenam ações de planejamento de recursos hídricos, mas por outro lado, desenvolvem atividades isoladas que podem privilegiar interesses particulares. 
Tabela 1. Comparação das principais características de implementação do Sistema Integrado de Gerenciamento de Recursos Hídricos (SIGREH) no Equador, no Brasil e no Estado de São Paulo.

\begin{tabular}{|c|c|c|c|}
\hline Pais/Estado & Equador & Brasil & Estado de São Paulo \\
\hline Legislação & $\begin{array}{l}\text { Constituição da República do Equador (2008); } \\
\text { Código Orgânico de Organização Territorial } \\
\text { (2010); Lei Orgânica de Recursos Hídricos, Usos } \\
\text { e Aproveitamento da Água (2014); } \\
\text { Lei de Regulação de Recursos Hídricos (2015). }\end{array}$ & $\begin{array}{l}\text { Constituição da República Federativa do } \\
\text { Brasil; Código de Águas; Política Nacional de } \\
\text { Águas (Lei n 9.433/97); Legislações } \\
\text { Estaduais de Gestão de Águas; Criação da } \\
\text { Agência Nacional de Águas (ANA, Lei } \\
\text { 9984/2000); Marco legal para a integração } \\
\text { das águas subterrâneas e superficiais } \\
\text { (Resoluções N 15/2001, 16/2001 e 22/2002); } \\
\text { Resolução n.32 (2003) do Conselho Nacional } \\
\text { de Recursos Hídricos. }\end{array}$ & $\begin{array}{c}\text { Lei Estadual n } 7.663 / 91 \\
\text { Decreto } 3678 / 1993 \\
\text { Decreto } 37300 / 1993 \\
\text { Lei 9034/1994 -PERH 94/95 } \\
\text { Lei Estadual n } 10.020 / 98 \\
\text { Lei } 12183 / 2005\end{array}$ \\
\hline $\begin{array}{l}\text { Organização } \\
\text { Política }\end{array}$ & $\begin{array}{l}\text { República Unitária; } 221 \text { Governos Autônomos } \\
\text { Descentralizados (GADs). }\end{array}$ & Federação; 5.564 municípios. & $\begin{array}{l}645 \text { municípios. } \\
\text { Municípios organizados em } 42 \text { regiões de governo, } \\
14 \text { regiões administrativas e } 4 \text { regiões }\end{array}$ \\
\hline $\begin{array}{l}\text { Organização } \\
\text { Político- } \\
\text { Administrativa }\end{array}$ & $\begin{array}{l}\text { O Estado organiza-se territorialmente em regiões, } \\
\text { províncias, municípios e freguesias rurais. }\end{array}$ & $\begin{array}{l}\text { União, estados, Distrito Federal e municípios, } \\
\text { todos autónomos nos termos da Constituição, } \\
\text { Constituição (1988); Art. } 18 .\end{array}$ & $\begin{array}{l}\text { metropolitanas. } \\
22 \text { Unidades de Gerenciamento de Recursos } \\
\text { Hídricos (UGRH) e } 21 \text { Comitês de Bacia } \\
\text { Hidrográfica }(\mathrm{CBH}) \text {. }\end{array}$ \\
\hline
\end{tabular}




\begin{tabular}{|c|c|c|c|}
\hline Pais/Estado & Equador & Brasil & Estado de São Paulo \\
\hline $\begin{array}{l}\text { Estrutura legal } \\
\text { e institucional } \\
\text { para a GIRH. }\end{array}$ & $\begin{array}{l}\text { O Sistema Nacional Estratégico da Água está } \\
\text { formado por seis instâncias: SENAGUA, o } \\
\text { Conselho Intercultural e Plurinacional da água, } \\
\text { ministérios de agricultura, ambiente e saúde, } \\
\text { Governos autônomos descentralizados (GADs), } \\
\text { Conselho de bacia e Comitê de bacia. }\end{array}$ & $\begin{array}{l}\text { Política Nacional de Recursos Hídricos } \\
\text { (PNRH); Sistema Nacional de Gerenciamento } \\
\text { de Recursos Hídricos (SNGREH); Conselho } \\
\text { Nacional de Recursos Hídricos (CNRH); } \\
\text { Agência Nacional de Águas (ANA); Comitês } \\
\text { de bacias hidrográficas (CBH). }\end{array}$ & $\begin{array}{l}\text { Sistema Integrado de Gerenciamento de Recursos } \\
\text { Hídricos (SIGRH), que tem como base o Plano } \\
\text { Estadual de Recursos Hídricos (PERH), a partir } \\
\text { dos Planos de Bacia específico de cada um dos } 21 \\
\text { Comitês de Bacias Hidrográficas (CBH). O } \\
\text { Sistema conta também com o Fundo Estadual de } \\
\text { Recursos Hídricos (FEHIDRO) para viabilizar } \\
\text { financeiramente projetos ligados aos Recursos } \\
\text { Hídricos. }\end{array}$ \\
\hline
\end{tabular}

Representatividade e legalidade na conformação dos Comitês de Bacia.

A bacia hidrográfica é a referência de planejamento e gestão.

A bacia hidrográfica é a referência de Com o PNRH, as decisões sobre os recursos Organização planejamento e gestão.

comunitária e A sociedade civil pode participar através de suas participativa organizações.

na GIRH. Problemas administrativos, normativos e financeiros na conformação dos Comitês de Bacia. hídricos são descentralizadas e

compartilhadas entre os usuários e os representantes do poder público. Os Comitês têm autonomia financeira para gerenciar seus próprios recursos.
As decisões são tomadas pelos envolvidos em conflitos decorrentes do uso de recursos da bacia, sejam estes os usuários de recursos hídricos, governos municipais e outras formas de organização da sociedade, como sindicatos e entidades não-governamentais. 


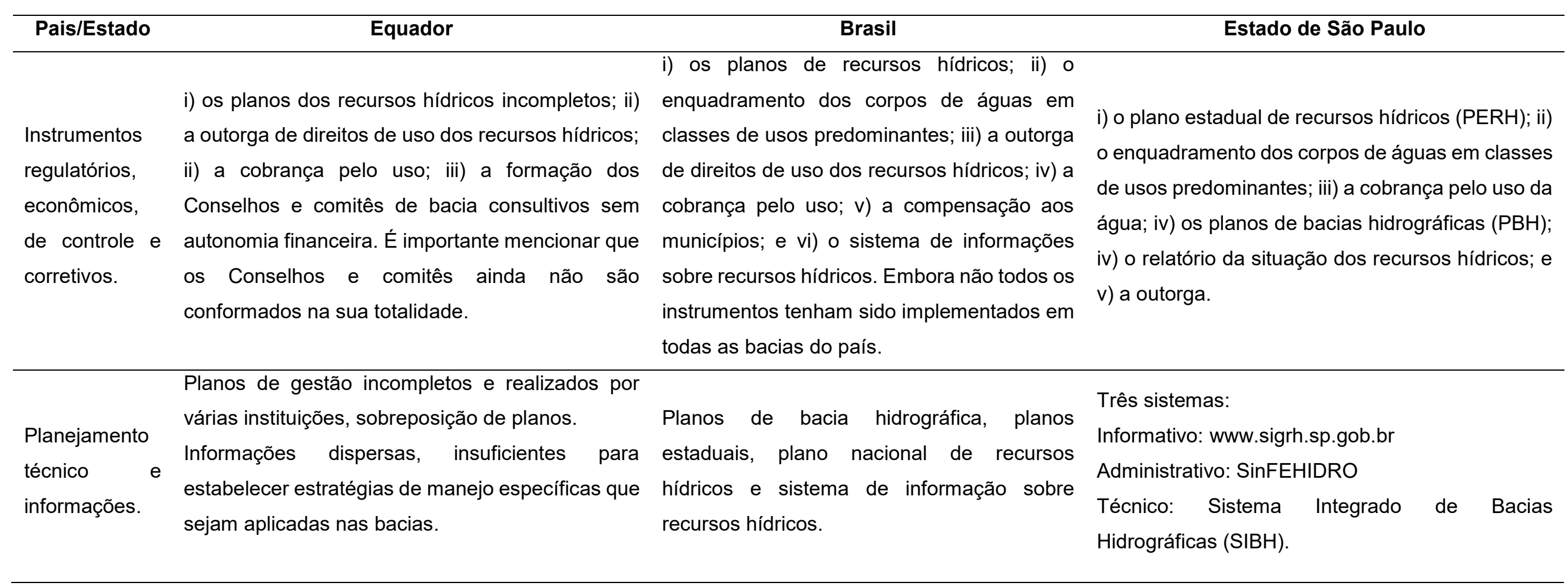




\section{4. ÁREA DE ESTUDO}

\subsection{Caracterização da área de estudo}

Neste capítulo serão apresentadas as informações que caracterizam a área de estudo nos aspectos físicos e econômicos.

\subsubsection{Localização da área de estudo}

A Cordilheira dos Andes constitui a principal feição geográfica do Equador, pois atravessa o país de norte a sul, gerando três regiões distintas: Litoral, Serra e Amazônia. Na região da Serra Equatoriana, os Andes dividem-se nas cordilheiras Real e Ocidental que se encontram separadas pela depressão Vale Interandino. Esse vale encontra-se dividido em segmentos pela presença de estruturas vulcânicas que interferem na orientação da depressão, constituindose nos segmentos: Vale Interandino Norte (VIN), Vale Interandino Central (VIC) e Vale Interandino Sul (VIS) (Figura 6).

A área de estudo localiza-se na província de Chimborazo e compreende a Bacia do Baixo Rio Chambo (BBRCH), que está localizada na região sudeste, entre as coordenadas 9.840 .000 e $9.800 .000 \mathrm{~m} \mathrm{~S} \mathrm{e} 742.000$ e $784.000 \mathrm{~m} \mathrm{E}$, com uma superfície de $1.481 \mathrm{~km}^{2}$, o que representa $22,8 \%$ da superfície total da província. Na BBRCH localizam-se os principais municípios e centros povoados como: Riobamba, Guano e Chambo e os povoados rurais de Llío, San Pablo, San Andrés, San José de Chazo, Ilapo, pertencentes ao município de Guano; Pungalá no município de Riobamba; Bayushuig no município de Penipe e Villa Unión no município de Colta (Figura 7). 


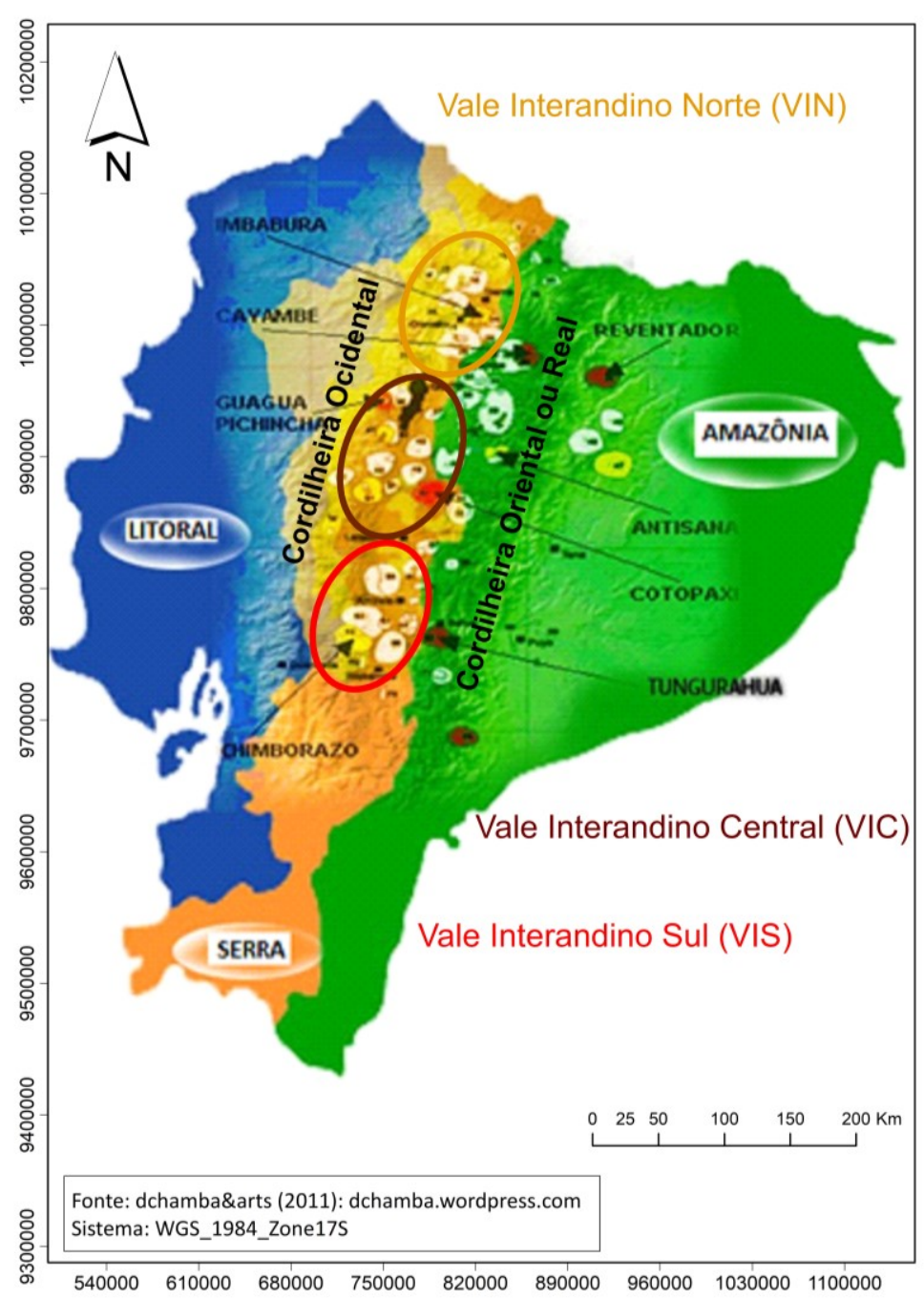

Figura 6. Principais regiões do Equador: Litoral, Serra e Amazônia. Divisão da Cordilheira dos Andes em: Cordilheira Real, Ocidental e os segmentos do Vale Interandino (Vale Interandino Norte, Central e Sul).

A BBRCH limita-se ao norte com a província de Tungurahua, ao leste, com o município Penipe, ao sul, com os municípios de Colta e Guamote. Dista 166 $\mathrm{km}$ da capital do Equador (Quito) e a principal via de acesso é a rodovia Panamericana sul (E35) até Riobamba, de onde o trajeto continua por $7 \mathrm{~km}$ pela rodovia Riobamba-Guano (Figura 7). 
a)
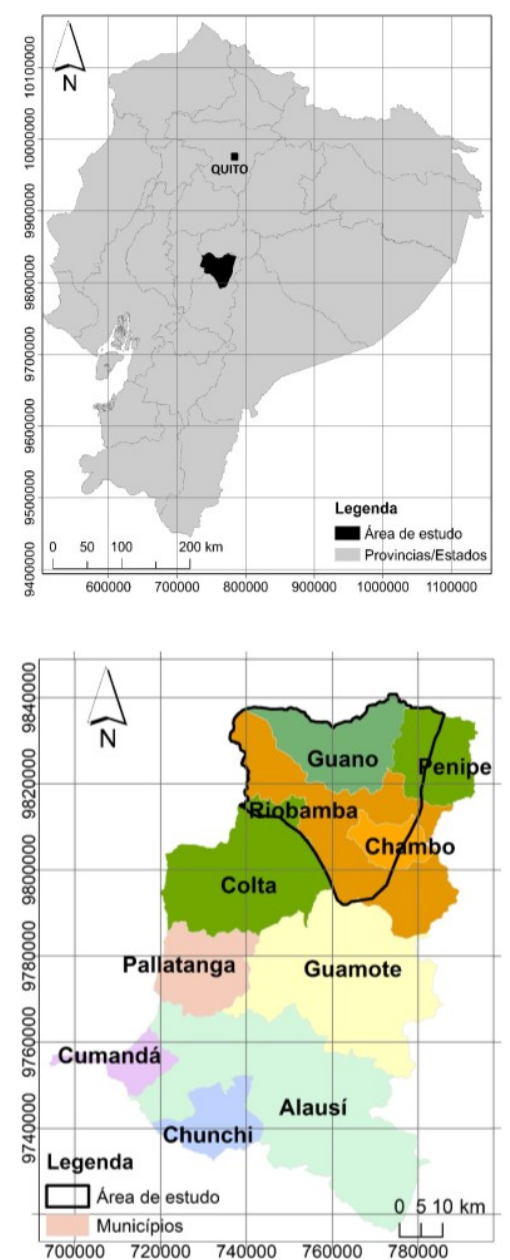

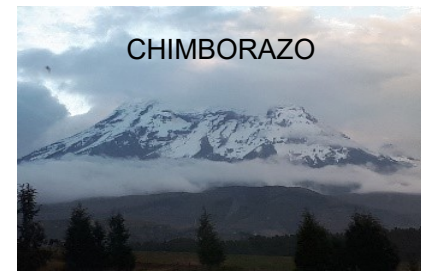

c)

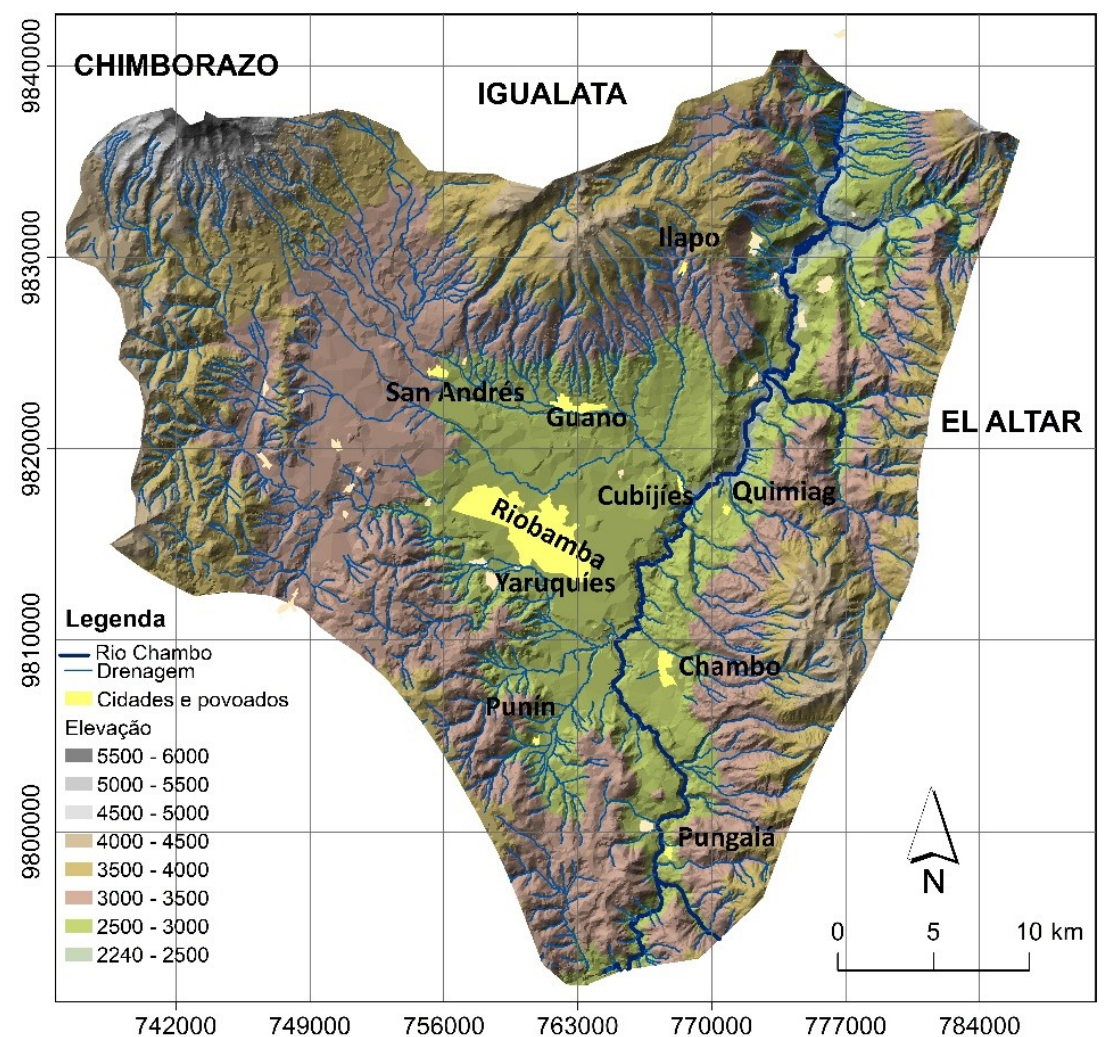

Figura 7. Localização da área de estudo na organização Político-Administrativo do Equador. a) Área de estudo com respeito à capital; b) Província de Chimborazo e limites da $\mathrm{BBRCH}$; c) $\mathrm{BBRCH}$ com as principais geleiras vulcânicas. 


\subsubsection{Geomorfologia}

O relevo na BBRCH distingue zonas com diferenciações morfológicas. No Oeste, predominam os vulcões que fazem parte da Cordilheira Ocidental, como o Chimborazo (6.268 m.s.n.m.) que constitui a elevação com maior altitude da zona de estudo e do país; o Carihuairazo (5.018 m.s.n.m.) e o Igualata (4.385 m.s.n.m.). A Leste, o relevo predominante caracteriza-se pela Cordilheira Oriental ou Real com montanhas como: o Tungurahua (5.023 m.s.n.m) e El Altar (5.319 m.s.n.m.). Na zona central, o Vale Interandino Sul onde localizam-se as principais áreas urbanas (Figura 8).

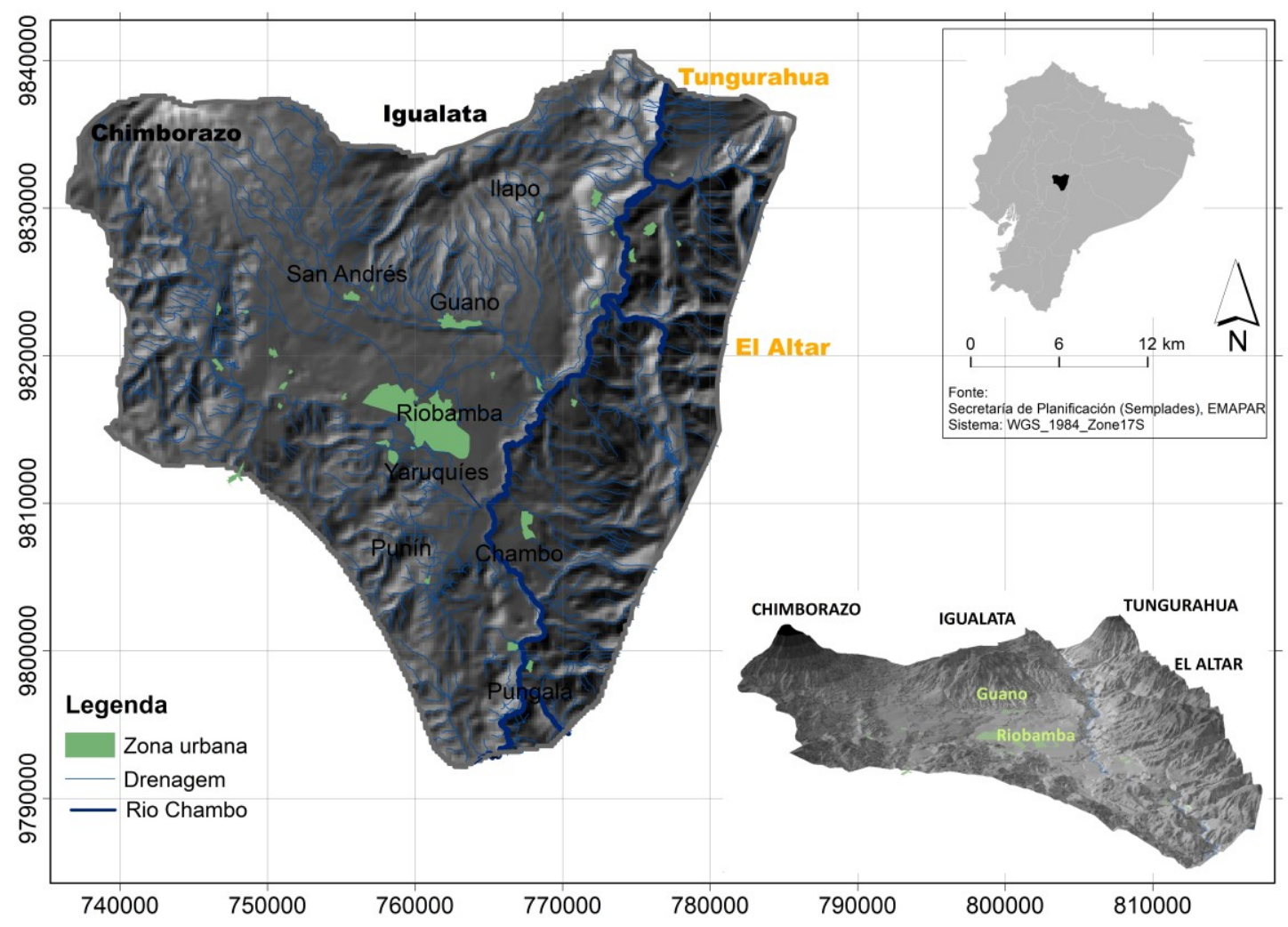

Figura 8. Principais feições morfológicas, geleiras vulcânicas e áreas urbanas na $B B R C H$.

A BBCH ocupa cerca de $42,1 \%$ da bacia do rio Chambo e o $22,8 \%$ da província do Chimborazo, faz parte da sub-bacia do rio Chambo que por sua vez forma parte da demarcação hidrográfica do rio Pastaza, definida pela SENAGUA em 2010. O rio Pastaza está situado no setor leste-nordeste da área de estudo 
e percorre quatro províncias, duas da Serra (Chimborazo e Tungurahua) e duas da Amazônia (Pastaza e Morona Santiago) (Figura 9).

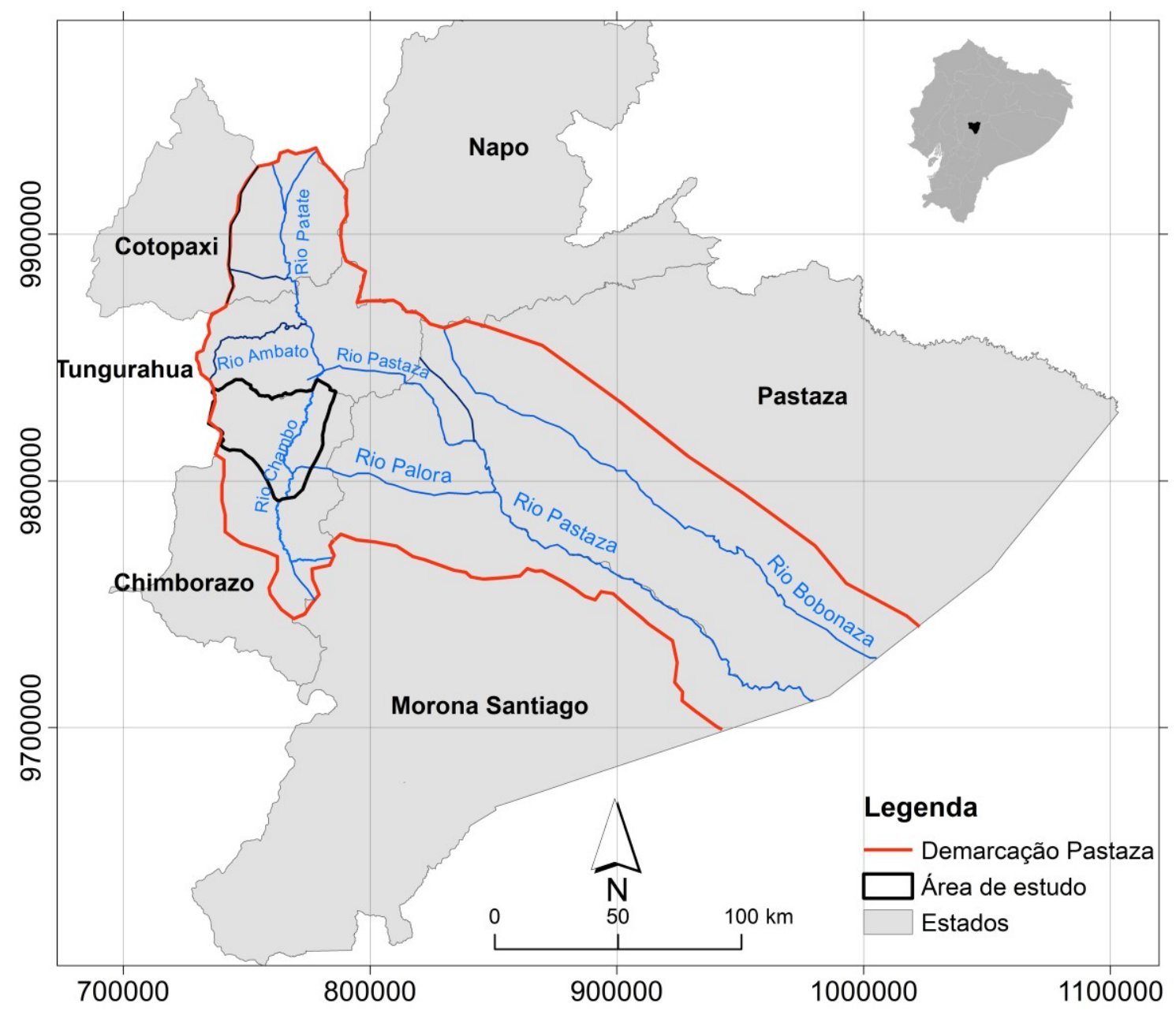

Figura 9. Localização da BBRCH na demarcação hidrográfica do rio Pastaza.

A área de estudo possui uma drenagem constituída por pequenos cursos d`água, formadores dos córregos: Chimborazo, Chibunga e Guano, formadores do rio Chambo a oeste e os rios Alao, Ishpi, Uldán, Blanco e Puela, a leste (Figura 10). 


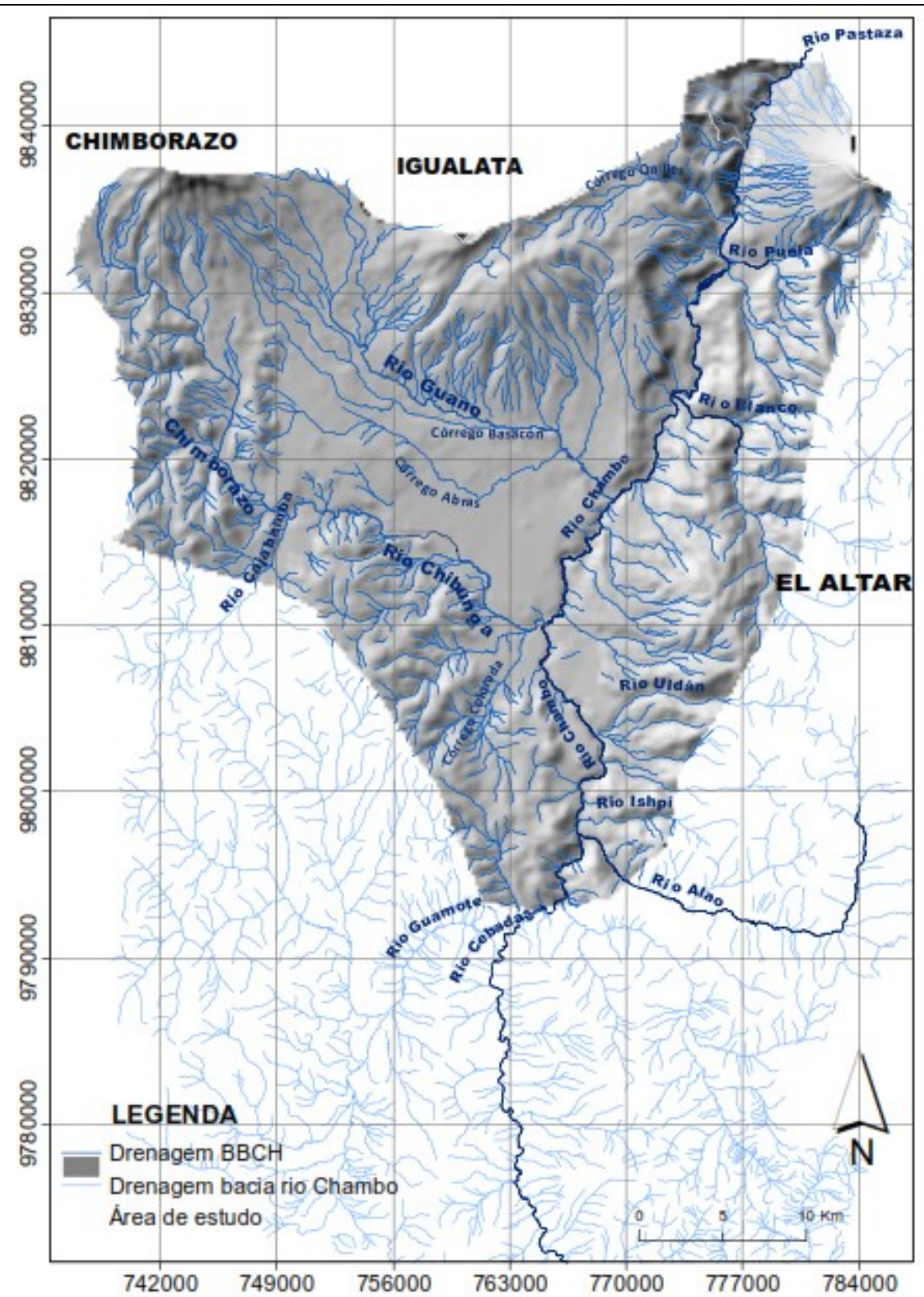

Figura 10. Drenagem da BBRCH. Principais rios orientais e ocidentais.

\subsubsection{Uso e ocupação do solo}

A preservação da qualidade do solo e de suas funções constitui uma condição primordial para a integridade ambiental. As formas de uso e ocupação do solo afetam diretamente a qualidade da água superficial e subterrânea. Neste trabalho foram mapeados tipos de solo e ocupação (Figura 11 e Figura 12).

Os solos da área apresentam uma fisionomia, predominantemente, de Altiplano (ecossistema de altitude das montanhas dos Andes). A classe de solo 
predominante é o Andisol, com 38,7\%, e ocorrência de cinza vulcânica, textura franco-arenosa e presença de minerais amorfos; já os outros tipos como o Mollisol (21,7\%), Inceptisol (15,9\%) e Entisol (15,2\%) e Histosol ocorrem em menores porcentagens (Senplades, 2012) (Figura 11).

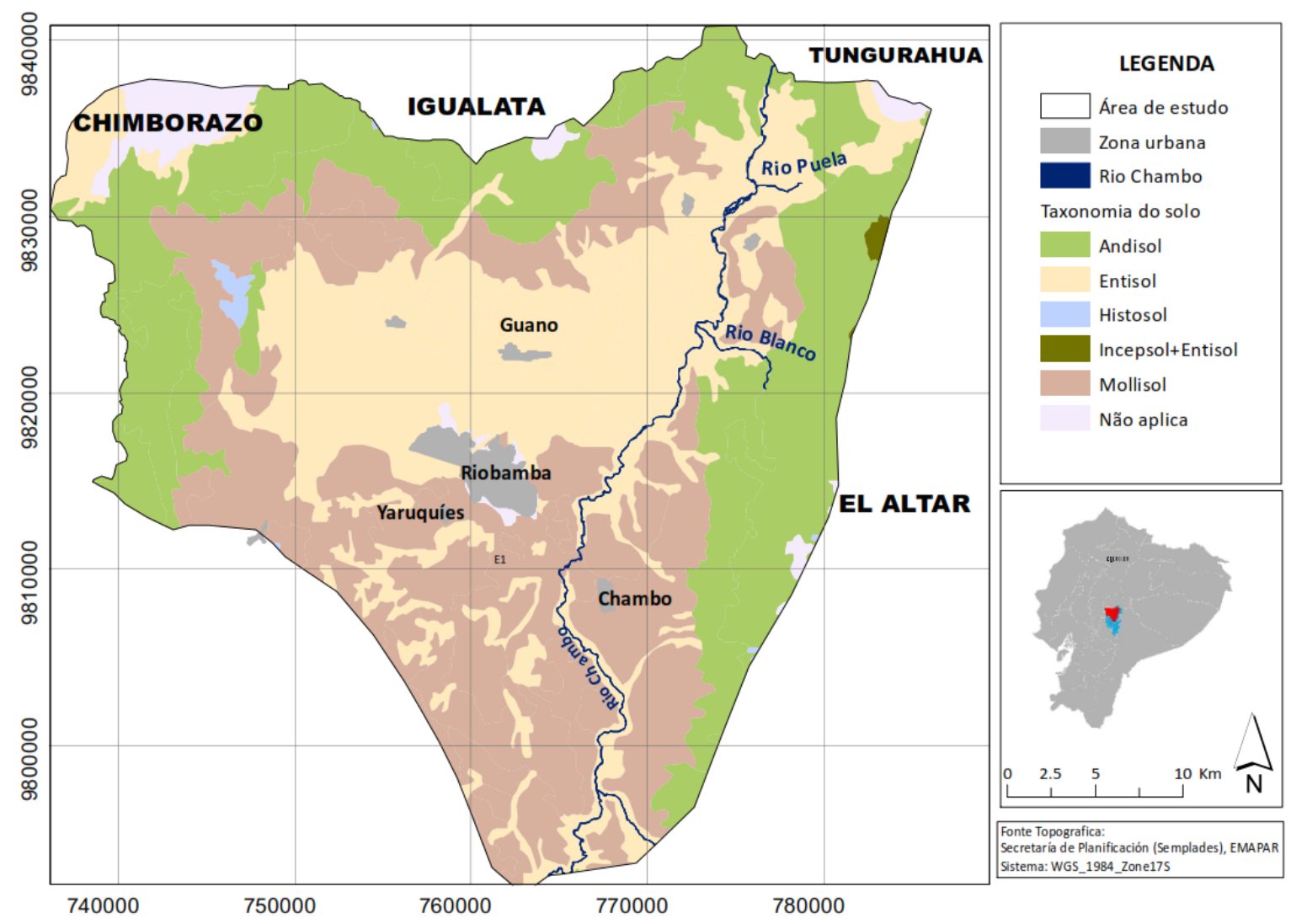

Figura 11. Classificação taxonômica dos solos na $B B R C H$

O mapa de uso e ocupação do solo foi obtido da Senplades (2012). Neste mapa, a área de estudo foi dividida em duas zonas: a zona rural e a urbana. $\mathrm{Na}$ primeira, foram classificadas as áreas agrícolas e de pecuárias em blocos. 0 bloco 0 correspondeu aos "pajonales"; o bloco 1 às culturas do milho; o bloco 2 às culturas de batata; o Bloco 3 vegetais; o bloco 4 frutas; o bloco 5 culturas de cereais, especialmente cevada; e o bloco 6 pastagens (que correspondem aos fragmentos florestais que tiveram intervenção do homem para criação de gado) e floresta nativa (que correspondem aos fragmentos florestais e às matas de páramo) (Figura 12). Vale a pena notar que na zona rural a agricultura constitui parte da identidade cultural de mais de $70 \%$ da população economicamente ativa da província (INEC, 2010) o que implica uma importante demanda de água 
para irrigação das diferentes culturas. São estas terras agrícolas as que abastecem as demandas dos principais mercados do Equador.

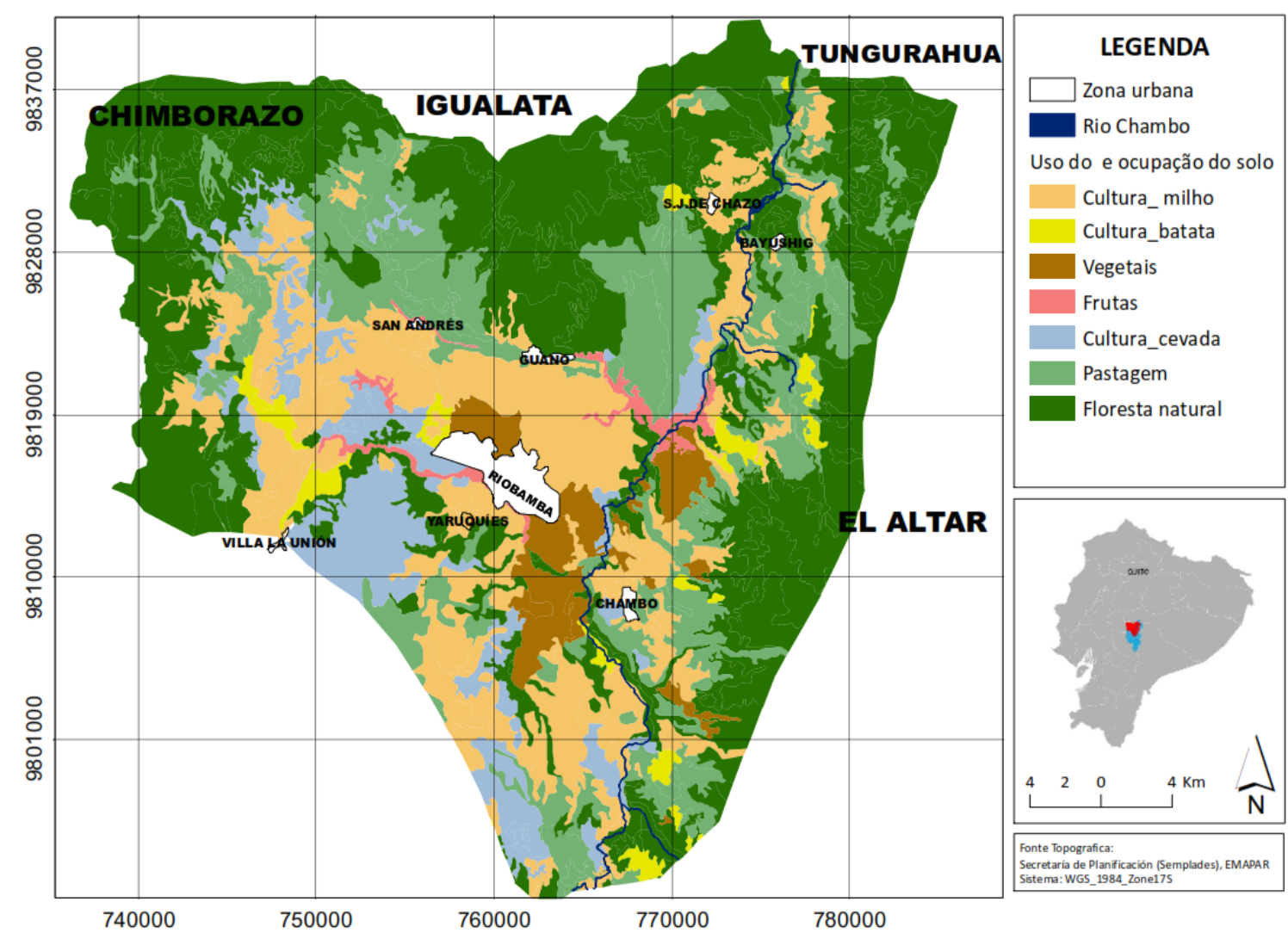

Figura 12. Uso e ocupação do solo identificando as áreas urbanas e rurais.

Na zona urbana da cidade de Riobamba identificou-se uma ocupação predominantemente residencial, seguida de outra mista (residencial, comercial, de serviços) e poucas zonas industriais. As maiores empresas estão representadas pela indústria do cimento (Cimento Chimborazo), da cerâmica, fábricas de lacticínios e de materiais de construção.

A cidade de Guano caracteriza-se pela pequena indústria têxtil e de tapeçaria, assim como a de calçados. Em Chambo predominam as atividades relacionadas a criação de animais de pequenas espécies, silvicultura e extração de madeira. Além de exploração de minas e pedreiras para a fabricação de tijolos (Senplades, 2012).

As mudanças no uso e na ocupação do território propiciam variações no aspecto demográfico. De acordo com o INEC, a população total dos municípios localizados na área de estudo chegou a 280.477 habitantes em 2010. 
O município de Riobamba tem 156.723 habitantes na área urbana, o que representa $69,4 \%$ da população, enquanto a área rural tem 69.018 habitantes $(30,6 \%)$ distribuídos em 11 povoados rurais. Destas Cubijíes é o povoado rural com menor população (2.514 habitantes) enquanto que San Luís (12.002 habitantes) é o povoado rural com maior população (INEC, 2010).

O crescimento demográfico nos povoados rurais é baixo (com taxas de crescimento inferiores a $1 \%$ ). Isto é devido à constante migração desde estes povoados para Riobamba e outras cidades do país e até para o exterior.

O município de Guano é composto por dois povoados urbanos e nove rurais. Tem uma população de 42.851 habitantes (18,1\% na área urbana e $81,9 \%$ na área rural). Já o município de Chambo tem a menor população da área de estudo. Tem uma população total de 11.885 habitantes, dos quais $38 \%$ estão na área urbana e $62 \%$ na área rural. Dessa população rural, 28\% (2.059 habitantes) estão diretamente envolvidos com o setor agrícola, cultivo de peixes, e pastagem (INEC, 2010).

Os três municípios (Riobamba, Guano e Chambo) englobam comunidades indígenas distribuídas no território. O perfil socioeconômico da população rural ( $40 \%$ do total da população da área de estudo) apresenta o mais baixo padrão socioeconômico do país. As zonas rurais têm baixa escolaridade e as condições de saúde, de habitação e de segurança são muito precárias (Senplades, 2012); (INEC, 2010).

\subsubsection{Clima}

A BBRCH tem variabilidade climática devido a sua localização no Vale Interandino, nos Andes equatorianos, onde a irregularidade orográfica (área de transição entre os Andes e a Amazônia), altitude, latitude e permanência das massas úmidas derivadas dos sistemas de ventos tropicais do oceano Atlântico originam uma grande variedade de climas em curtas distâncias (Clapperton \& Vera, 1886); (Rodgers, 1991).

Pourrot (1989) distinguiu dois tipos de climas gerais para o Vale Interandino, segundo a altitude. O clima mesotérmico semiúmido a úmido e o clima equatorial de alta montanha. O clima mesotérmico semiúmido a úmido ocorre no Vale Interandino e nas bacias que o contem, incluindo a BBRCH. Neste 
tipo de clima as temperaturas variam de 12 até $20^{\circ} \mathrm{C}$ e o regime de precipitação está constituído por duas estações secas e duas estações chuvosas. As estações secas ocorrem nos meses de junho a setembro e de dezembro a janeiro, enquanto as estações chuvosas ocorrem entre os meses de fevereiro, maio, outubro e novembro. Os meses mais chuvosos são março e abril, enquanto os meses menos chuvosos são julho e agosto.

O clima equatorial de alta montanha surge acima dos 3.200 metros de altitude. A temperatura oscila entre 4 e $8^{\circ} \mathrm{C}$.

O estudo hidrológico do $(\mathrm{CNRH}, 2007)$ aponta que a variação de temperatura em toda a bacia do rio Chambo é ampla, portanto, do ponto mais alto $(6.310 \mathrm{~m}$, no topo do Chimborazo) até o ponto mais baixo $(2.080 \mathrm{~m}$ na confluência do rio Chambo e Patate), as temperaturas médias variam de $-4{ }^{\circ} \mathrm{C}$ até $16{ }^{\circ} \mathrm{C}$.

Neste trabalho realizou-se a caracterização climática na $\mathrm{BBRCH}$, agrupando as estações meteorológicas de acordo com o regime de precipitação, conforme o exposto no trabalho de (Quispe, 2017).Esta metodologia será explicada na seção 5.1 e 6.3 . 


\section{MÉTODOS}

Este capítulo abrange a descrição dos métodos adotados para a elaboração deste trabalho. Dentre as atividades realizadas destacam-se:

$\checkmark$ Levantamento de dados existentes (bases cartográficas, dados meteorológicos, geológicos, hidrogeológicos e cadastro de poços e nascentes);

$\checkmark$ Zoneamento baseado nas características morfológicas da área de estudo;

$\checkmark$ Quantificação da recarga pelo cálculo do balanço hídrico do solo;

$\checkmark$ Coleta de amostras e análises químicas;

$\checkmark$ Uso de isótopos ${ }^{18} \mathrm{O}$ e ${ }^{2} \mathrm{H}$ na identificação da origem da água;

$\checkmark$ Elaboração de modelo hidrogeológico conceitual;

$\checkmark$ Quantificação regional da oferta e da demanda de recursos hídricos;

$\checkmark$ Elaboração de proposta de gestão de recursos hídricos.

\subsection{Levantamento de dados existentes}

5.1.1 Levantamento de bases cartográficas, dados meteorológicos, geológicos e hidrogeológicos

O levantamento das bases cartográficas foi efetuado mediante informações nos mapas de drenagem, topográficos, de uso e ocupação do solo, taxonômicos, de cobertura vegetal, no relatório técnico de geração de informação para a gestão do território equatoriano (Senplades, 2012) e demais publicações científicas (Barba, Robin, Samaniego, \& Eissen, 2008); (Naranjo, 2013); (Comité de la subcuenca del río Chambo, 2015); (Yan16); (Quispe, 2017).

As informações supracitadas foram compiladas, integradas e homogeneizadas em uma base digital, na escala 1:25.000, com o auxílio do programa Arcgis, versão 10.2.1 da ESRI. O sistema de coordenadas adotado foi o Universal Transverse Mercator (UTM), expresso em metros. Por sua vez, o datum selecionado foi WGS 1984, zona $17 S$. 
Os dados referentes à geologia da área de estudo foram compilados a partir das seguintes publicações:

- Trow (1976): primeiro estudo na região sobre a Cordilheira dos Andes;

- $\quad$ Sosa e Guevara (1978): cartografia geológica de Riobamba, escala 1:100.000;

- $\quad$ Baldock (1982) mapa geológico do Equador.

Além dos trabalhos supracitados, foram também consultados os trabalhos de conclusão de curso de Barba (2006), Yánez (2016) e Salguero (2017).

Com o intuito de melhorar a litoestratigrafia, foram realizadas análises estratigráficas e litológicas das informações dos perfis litológicos presentes nos relatórios técnicos dos poços tubulares perfurados pela EP-EMPAR. Além disso, foram realizadas observações de campo em San Pablo, Llío, Guano, Los Elenes, San Gerardo, Riobamba, Chambo, Cubijíes, Yaruquíes, Ilapo, Punín e Pungalá. Os depósitos vulcânicos observados nos afloramentos dos setores descritos foram correlacionados com litologias semelhantes às relatadas nos 6 registros de perfuração e as informações obtidas das 5 seções elétricas realizadas em 2016 (San Pablo, Los Elenes, Cubijíes e Pungalá) junto ao Instituto Nacional de Pesquisa Geológica Mineral Metalúrgica INIGEM e as duas sondagens elétricas realizadas por Lovato em 2010 (Figura 13).

A partir das correlações das informações descritas (perfis construtivos dos poços, seções elétricas, sondagens elétricas e colunas estratigráficas levantadas no campo) foram gerados três cortes na direção nordeste-sudeste (A-A', Llío-Yaruquíes) e leste-oeste (B-B', San Juan Rio Blanco e C-C', Rio Blanco-Guano) e definidas as unidades litológicas presentes na área de estudo (seção 6.3).

Posteriormente a evolução tectônica e estratigráfica da área de estudo foi elaborada considerando as unidades litológicas, estruturas tectônicas e características geomorfológicas identificadas em trabalhos de campo realizados em 2016 e 2017. 


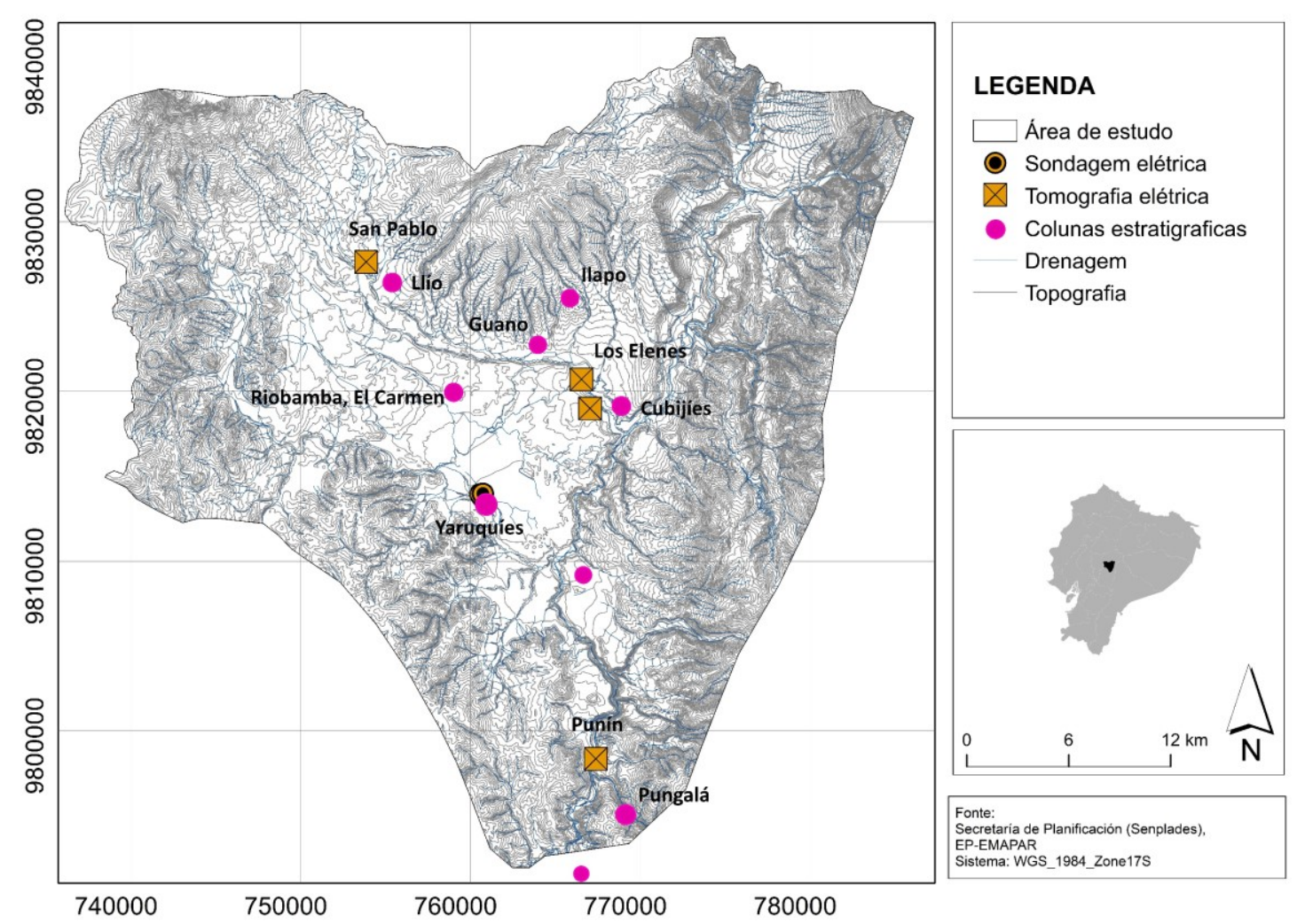

Figura 13. Seções elétricas e colunas estratigráficas realizadas em campo para a análises e correlações das principais formações e unidades litológicas presentes na $\mathrm{BBRCH}$.

Os dados e informações hidrometeorológicas foram obtidos através da consulta das estações do tipo climatológica, pluviométrica e hidrológica da rede meteorológica do INHAMI e no Sistema de Informações Hidrológicas da SENAGUA (Figura 14).

Foram analisadas as séries mensais de precipitação, temperatura e vazão de 29 estações, das quais 19 foram escolhidas como representativas (12 meteorológicas e 7 hidrológicas). Das 19 estações, 12 estão ativas e 7 fora de operação (Tabela 2, Figura 14).

As 12 estações meteorológicas, foram classificadas em grupos de acordo com: i) os regimes de chuva, ii) a localização, iii) a quantidade de dados existentes, número de anos de registro e presença de falhas das séries pluviométricas nas séries históricas (descontinuidades e falta de informação nos registros da série). 


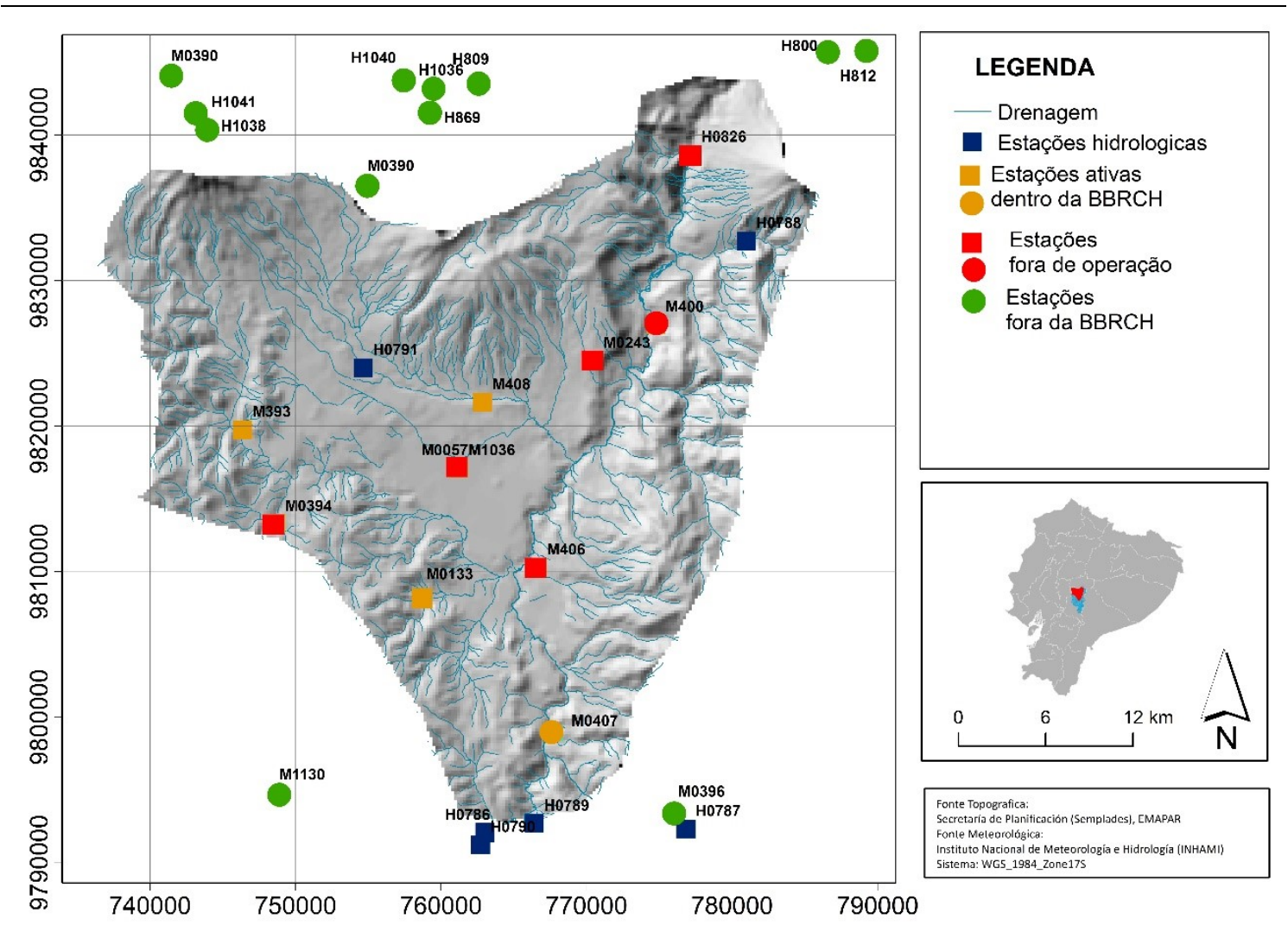

Figura 14. Estações climatológicas, pluviométricas e hidrológicas ativas e inativas na área de estudo.

Foram analisados os padrões de distribuição das chuvas em cada estação, avaliando-se os valores máximo e mínimo de precipitação por mês em um ano (janeiro a dezembro). Essa análise foi feita com intuito de agrupar as estações com distribuição de chuvas semelhantes e reconhecer os regimes que podem apresentar os dados dessa variável: regime unimodal (um pico máximo e mínimo de precipitação) e bimodal (dois picos máximos e dois mínimos).

Posteriormente, foi analisada a quantidade de dados existentes em cada estação, ou seja, o número de anos de registro de dados e as falhas nos mesmos. As falhas observadas (mudança na tendência dos dados, erros de transcrição) foram analisadas e corrigidas pelo método da dupla massa desenvolvido pelo Serviço Geológico dos Estados Unidos (USGS, 1966). Esse método consistiu em plotar no eixo $x$ uma estação independente (média do grupo de estações no mesmo período) versus a estação dependente no eixo y (Figura 15) (Anexo II). 
Tabela 2. Estações meteorológicas escolhidas para a BBRCH

\begin{tabular}{llcccccc}
\hline $\begin{array}{c}\text { Código } \\
\text { estação }\end{array}$ & Nome & Estado & \multicolumn{2}{c}{$\begin{array}{c}\text { Localização } \\
\text { UTM E }\end{array}$} & \multicolumn{2}{c}{$\begin{array}{c}\text { Altitude } \\
\text { UTM N }\end{array}$} & $\begin{array}{c}\text { Período de } \\
\text { m.s.m. }\end{array}$ \\
& & & registro & anos \\
\hline M0057 & Riobamba aeroporto & F & 761223 & 9817103 & 2760 & 1946 & 1986 \\
M0133 & Guaslan & A & 759976 & 9809268 & 2850 & 1963 & 2014 \\
M0243 & Pungales & F & 770509 & 9824467 & 2550 & 1984 & 2000 \\
M0393 & San Juan Chimborazo & A & 746383 & 9819731 & 3220 & 1963 & 2015 \\
M0394 & Cajabamba & F & 748633 & 9813276 & 3160 & 1964 & 2001 \\
M0406 & Chambo finca Guadalupe & F & 766626 & 9810274 & 2640 & 1975 & 1990 \\
M0408 & Guano & A & 763119 & 9821994 & 2688 & 1979 & 2015 \\
M1036 & Riobamba politécnica & F & 761223 & 9817103 & 2740 & 1978 & 2015 \\
M0390 & Urbina & A & 757532 & 9835544 & 3610 & 1963 & 2015 \\
M0396 & Alao & A & 779743 & 9791264 & 3200 & 1964 & 2015 \\
M0400 & Penipe & F & 774780 & 9826951 & 2460 & 1964 & 1985 \\
M0407 & Licto & A & 766767 & 9799887 & 2840 & 1975 & 2015 \\
\hline
\end{tabular}

Posteriormente avaliou-se a tendência linear entre as precipitações acumuladas das estações consideradas nos eixos $x$ e $y$, o ajuste da reta e o coeficiente de correlação $\left(R^{2}\right)$. Apenas as correlações cujo coeficiente $\left(R^{2}\right)$ seja próximo de 1 ou maior que 0,7 (como sugerido por Kennedy et al.,1982) foram consideradas para o preenchimento de dados (falhas) neste estudo (Anexo II).

A partir dos dados das precipitações multianuais foi elaborado o mapa de isoietas, através da interpolação das médias anuais das estações descritas anteriormente. Os dados foram interpolados mediante o método de interpolação de krigagem ordinária, o qual é amplamente utilizado em trabalhos de hidrologia no Equador (Quispe, 2017); (Procel, 2008); (Peñafiel, 2009).

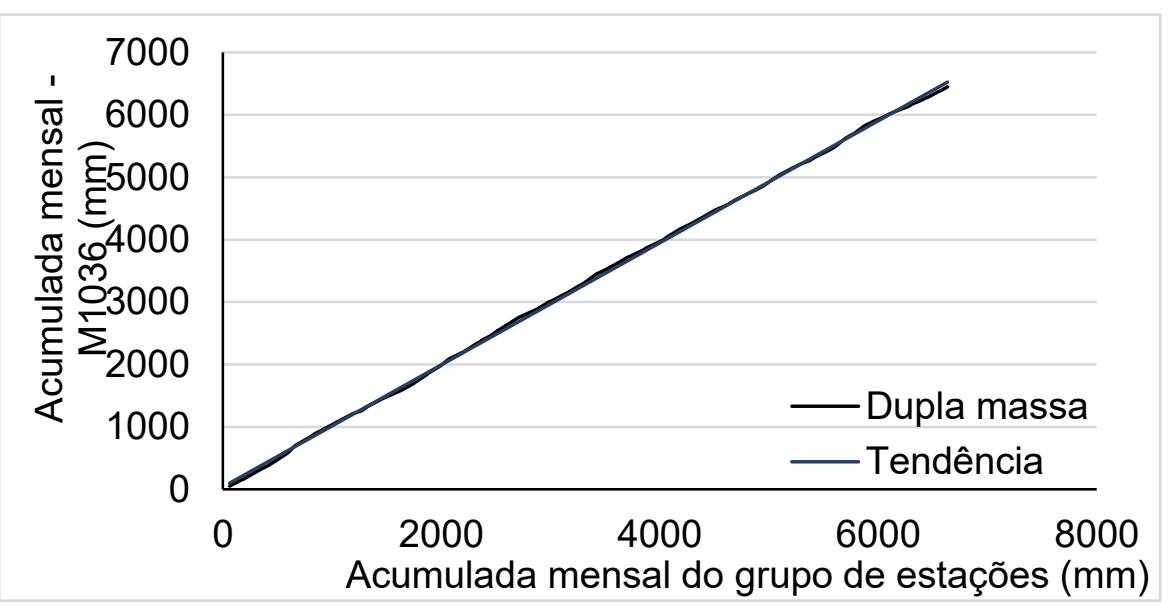

Figura 15. Método da dupla massa para a validação de dados de precipitação em séries mensais e anuais. 
A análise de temperatura envolveu a mesma avaliação realizada e descrita para a precipitação (coleta de dados, classificação de estações, análise de séries temporais, análise de confiabilidade de informações). Após essa análise das 12 estações localizadas na BBRCH, foram selecionadas 4 (M0057, M1036, M0243, M0133) para caracterizar a temperatura já que eram as únicas que tinham dados dessa variável (Tabela 3).

Tabela 3. Estações para análises de temperatura na BBRCH.

\begin{tabular}{|c|c|c|c|c|c|c|c|}
\hline \multirow{2}{*}{$\begin{array}{l}\text { Código } \\
\text { estação }\end{array}$} & \multirow{2}{*}{ Nome } & \multirow{2}{*}{ Estado } & \multicolumn{2}{|c|}{ Localização } & \multirow{2}{*}{$\begin{array}{l}\text { Altitude } \\
\text { m.s.n.m. }\end{array}$} & \multirow{2}{*}{\multicolumn{2}{|c|}{$\begin{array}{l}\text { Período de } \\
\text { registro } \\
\text { anos }\end{array}$}} \\
\hline & & & UTM E & UTM N & & & \\
\hline M0057 & Riobamba aeroporto & $\mathrm{F}$ & 761223 & 9817103 & 2760 & 1946 & 1986 \\
\hline M0133 & Guaslan & $A$ & 759976 & 9809268 & 2850 & 1963 & 2014 \\
\hline M0243 & Pungales & $\mathrm{F}$ & 770509 & 9824467 & 2550 & 1984 & 2000 \\
\hline M1036 & Riobamba politécnica & $\mathrm{F}$ & 761223 & 9817103 & 2740 & 1978 & 2015 \\
\hline
\end{tabular}

Para a caracterização hidrológica, avaliaram-se os dados de 7 estações (dentro e fora da área de estudo) da rede do INAMHI. Das 7 estações, 6 estão ativas e 1 fora de operação. Adicionalmente, analisaram-se os dados da estação H0826, a que foi considerada como ponto mais baixo da bacia (confluência do rio Chambo com o rio Patate (Tabela 4; Figura 14). Nestas estações avaliou-se a distribuição temporária das vazões médias mensais.

Tabela 4. Estações hidrológicas escolhidas para a BBRCH.

\begin{tabular}{|c|c|c|c|c|c|c|}
\hline \multirow{2}{*}{$\begin{array}{l}\text { Código } \\
\text { estações }\end{array}$} & \multirow{2}{*}{ Nome } & \multirow{2}{*}{ Estado } & \multicolumn{2}{|c|}{ Localização } & \multirow{2}{*}{$\begin{array}{c}\text { Altitude } \\
\text { (m.s.n.m.) }\end{array}$} & \multirow{2}{*}{$\begin{array}{l}\text { Período de } \\
\text { registro } \\
\text { (anos) }\end{array}$} \\
\hline & & & Leste & Norte & & \\
\hline $\mathrm{H} 0786$ & Guamote - Cebadas & $A$ & 763003 & 9792069 & 2864 & $2005-2014$ \\
\hline $\mathrm{H} 0787$ & Alao & $A$ & 776829 & 9792312 & 3200 & $1962-2014$ \\
\hline H0788 & Puela - Chambo & $A$ & 780994 & 9832690 & 2475 & $1954-2015$ \\
\hline H0789 & Guargualla - Cebadas & $A$ & 766422 & 9792692 & 2828 & $1964-2015$ \\
\hline H0790 & Cebadas - Guamote & $A$ & 762724 & 9791230 & 2840 & $1965-2015$ \\
\hline H0791 & Balsacón - San Andrés & $A$ & 754673 & 9823993 & 3112 & $1962-2015$ \\
\hline H0826 & Chambo - Cahuaji & $\mathrm{F}$ & 777221 & 9838623 & 2295 & 1978-1998 \\
\hline
\end{tabular}


5.1.2 Levantamento das informações dos poços e nascentes existentes na $B B R C H$

Os dados de poços e nascentes foram levantados por meio da consulta aos arquivos da EP-EMAPAR, da SENAGUA, do INHAMI e das empresas de consultoria.

Os dados dos poços foram avaliados quanto à qualidade da informação, dando especial atenção aos poços que continham as seguintes informações: localização, dados construtivos, parâmetros hidráulicos, descrição litológica, ensaios de bombeamento e análises físico químicas pretéritas. Igualmente para as nascentes foram avaliados dados de localização e vazão, principalmente.

Todas as informações obtidas foram sistematizadas e catalogadas em planilha Excel da Microsoft (versão 1802). A seguir, procedeu-se um tratamento dos dados preexistentes mediante análise estatística clássica (máximo, mínimo, média e mediana), utilizando-se, para isso, o mesmo programa Excel.

Foram levantados 31 poços e 32 nascentes, sendo que deste total foram selecionados, respectivamente, 8 poços e 8 nascentes que atenderam ao mínimo de informações supracitadas (Figura 16).

Essas informações constituíram a base da análise hidrogeológica e contribuíram para a seleção dos poços e nascentes que seriam amostrados para a posterior análise hidrogeológica e hidrogeoquímica. 


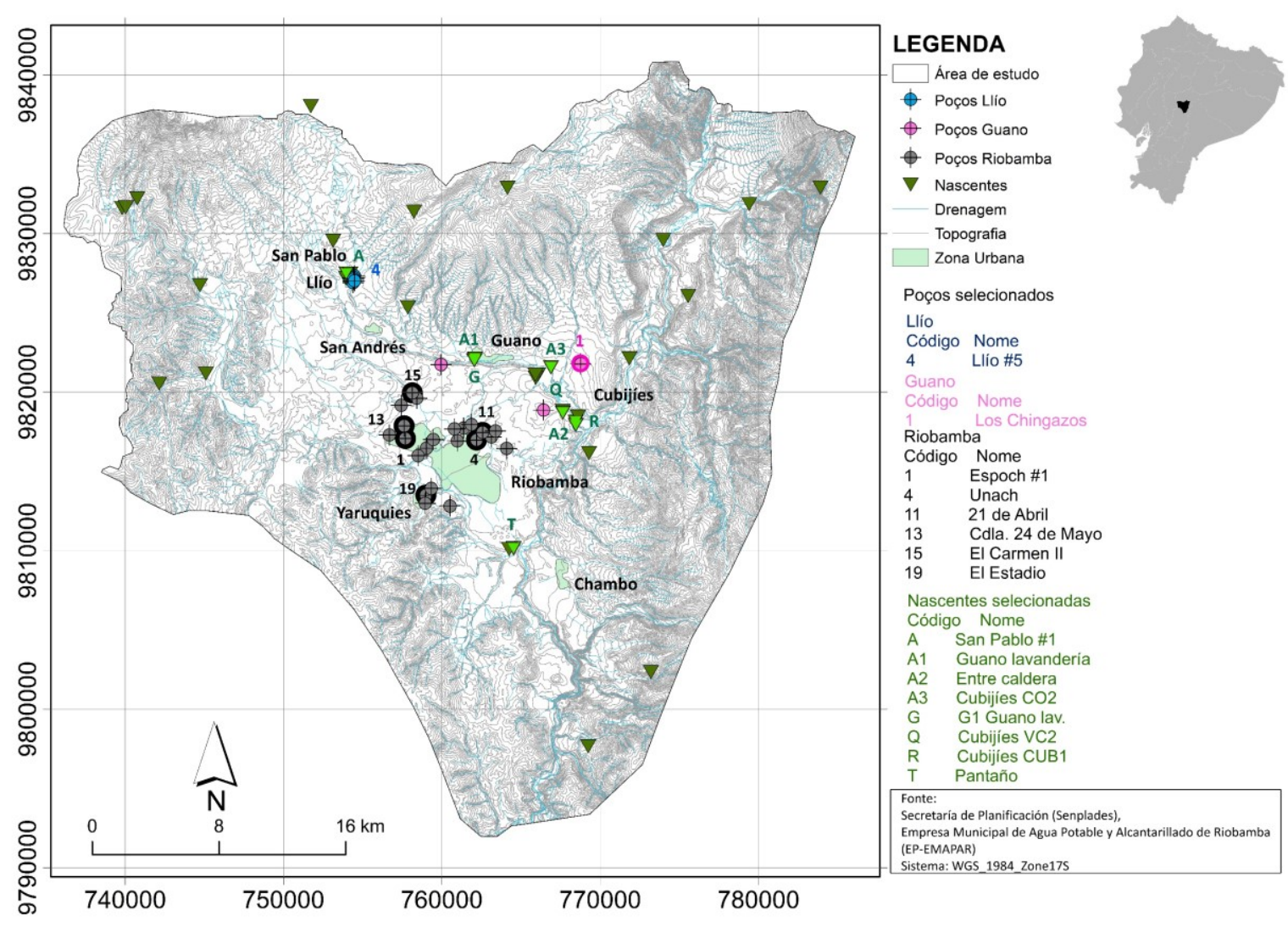

Figura 16. Poços e nascentes cadastradas na $\mathrm{BBRCH}$.

\subsection{Zoneamento do meio físico da BBRCH}

A aplicação do zoneamento baseou-se nas informações dos mapas topográficos, de drenagem, de uso e ocupação atual do solo, de taxonomia do solo, e do mapa geológico.

As informações desses mapas foram utilizadas visando a identificação das áreas (neste trabalho referidas como zonas) com diferentes extensões, distintas características morfológicas (por exemplo: altitude, elevações e vulcões, direção da drenagem, tipos de drenagem, divisores de águas, declividade), de uso do solo (por exemplo: agrícola, urbano) e distintos materiais geológicos (por exemplo: materiais de diferentes granulometrias e condutividades hidráulicas. 
A partir desse zoneamento foi analisado: i) o balanço hídrico local (devido às precipitações); ii) a recarga lateral (devido às geleiras); iii) os tipos de água; iv) as estimativas de demandas e ofertas de água; v) os possíveis conflitos entre usuários da água; e vi) a proposta de gestão integrada de recursos hídricos.

\subsection{Balanço hídrico}

A análise do balanço hídrico local na $\mathrm{BBRCH}$ foi realizada conforme a disponibilidade dos dados de cada uma das zonas definidas na seção 5.2. O cálculo do balanço hídrico ou da recarga local devido à chuva nas diferentes zonas (Z2 - Z8) foi feito através da metodologia proposta por (Thornthwaite \& Mather, 1948), segundo a equação:

$$
\mathrm{P}=\mathrm{ESC}+\Delta \mathrm{ARM}+\mathrm{ETR}+\mathrm{I}+\mathrm{R}
$$

Onde: $P$ é a precipitação $(\mathrm{mm})$; ESC é o escoamento superficial $(\mathrm{mm})$, incluindo a interceptação; ETR é a evapotranspiração real $(\mathrm{mm}) ; \triangle A R M$ é a variação no armazenamento de água no solo $(\mathrm{mm})$; I é a infiltração ou recarga $(\mathrm{mm})$ e $R$ as derivações de água da bacia $(\mathrm{mm})$.

Para o cálculo do escoamento foi utilizado o método de Fenn et al. (1975), adaptado às condições do solo na $\mathrm{BBRCH}$. Assim, realizou-se a análise do escoamento superficial, através da sobreposição dos mapas de taxonomia do solo (Figura 11), uso e ocupação do solo (Figura 12) e de declividade do terreno (Figura17), com o intuito de evidenciar as capacidades de permeabilidade do solo.

O mapa de declividade do terreno na área de estudo foi elaborado a partir do Modelo Digital de Terreno (MDT), construído, por sua vez, com o mapa topográfico do Instituto Geográfico Militar (IGM), na escala 1:25.000. No mapa, expresso em porcentagem (obtido do produto da tangente do ângulo que define a irregularidade do solo), definiram-se três intervalos segundo a Sociedade Americana de Engenheiros Civis (1969). Esses intervalos consideraram as declividades menores que $2 \%$ como baixa declividade (relevos com trechos de planície); de $2 \%$ a $7 \%$, declividades moderadas (relevos com maciços e 
planaltos) e maiores que 7\%, altas declividades (relevos de cordilheira) (Figura 17).

O mapa taxonômico caracterizou 5 tipos diferentes de solos: Andisol, Molisol, Incepsol, Entisol, Histosol. Esses foram analisados segundo suas características e porcentagens de areia e argila. Os solos com alta porcentagem de argila foram considerados como impermeáveis, com baixa capacidade de infiltração, enquanto os solos com altos teores de areia foram considerados como permeáveis, ou com alta capacidade de infiltração.

Note-se que, para a aplicação e adaptação dessa metodologia na área de estudo, considerou-se a precipitação média mensal e a temperatura média mensal estimada da série histórica da estação meteorológica, localizada em cada zona. Também foram considerados os parâmetros de evapotranspiração potencial (ETP), de evapotranspiração real (ETR), de variação no armazenamento $(\triangle A R M)$, de infiltração $(\mathrm{I}) \mathrm{e}$ as derivações de água.

Devido à falta de informação hidrológica, climatológica e meteorológica na zona 1, recorreu-se estimar a recarga lateral oeste devido ao degelo do vulcão Chimborazo e a recarga lateral do vulcão Igualata através da aplicação da Lei de Darcy, levando-se em consideração as características descritas na seção 5.3 e a presunção de que a altitude topográfica das nascentes cadastradas pela EPEMAPAR constitui a altitude da superfície das águas subterrâneas. Com estas premissas, estimou-se a recarga da zona 1 através da equação:

$$
\begin{gathered}
\mathrm{Q}=\mathrm{q} * \mathrm{~A} \\
\mathrm{q}=\mathrm{K} * \Delta \mathrm{h} / \Delta \mathrm{L}
\end{gathered}
$$

Onde: $Q$ é a vazão em $\mathrm{m}^{3} / \mathrm{s}$; $q$ é o fluxo de água representado pelo produto de multiplicação da condutividade hidráulica $(K$ em $\mathrm{m} / \mathrm{s})$ pelo gradiente hidráulico, calculado pela relação entre a diferença de cargas hidráulicas $(\Delta h=h 1$ $h 2$, em $\mathrm{m}$ ) e a variação da longitude entre os pontos de diferentes cargas hidráulicas considerados $(\Delta L$, em $\mathrm{m})$; e $A$ corresponde à área da seção transversal definida pelo comprimento da linha potenciométrica correspondente a h2 e a espessura da formação geológica atravessada pelo o fluxo (Figura 18). 


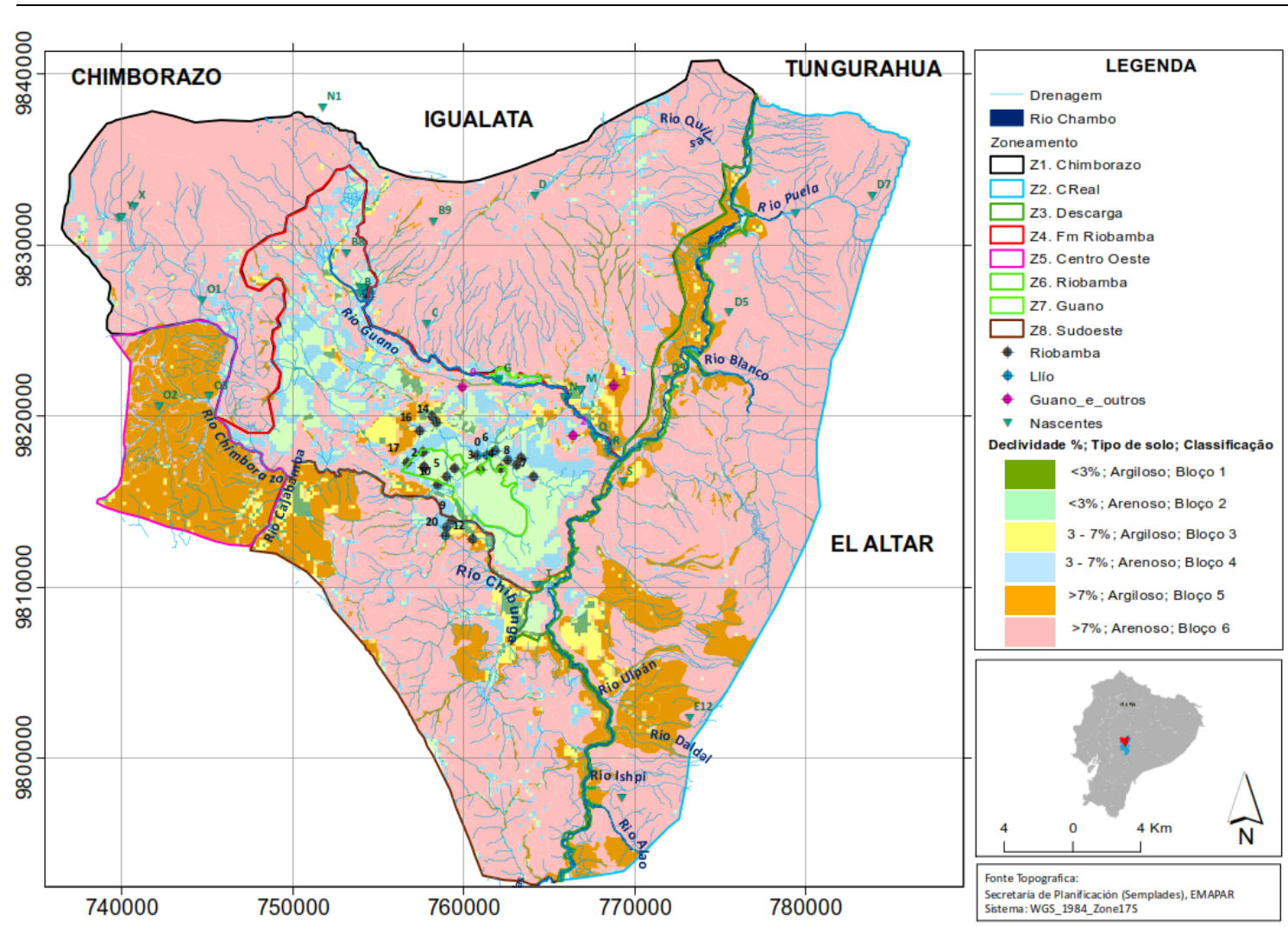

Figura 17. Zoneamento e intervalos de declividade do terreno: declividades menores que $2 \%$ baixa declividade (relevos com trechos de planície junto à hidrografia da bacia); de $2 \%$ a $7 \%$, declividades moderadas (relevos pouco acidentados); e maiores que 7\% altas declividades (relevos mais acidentados).

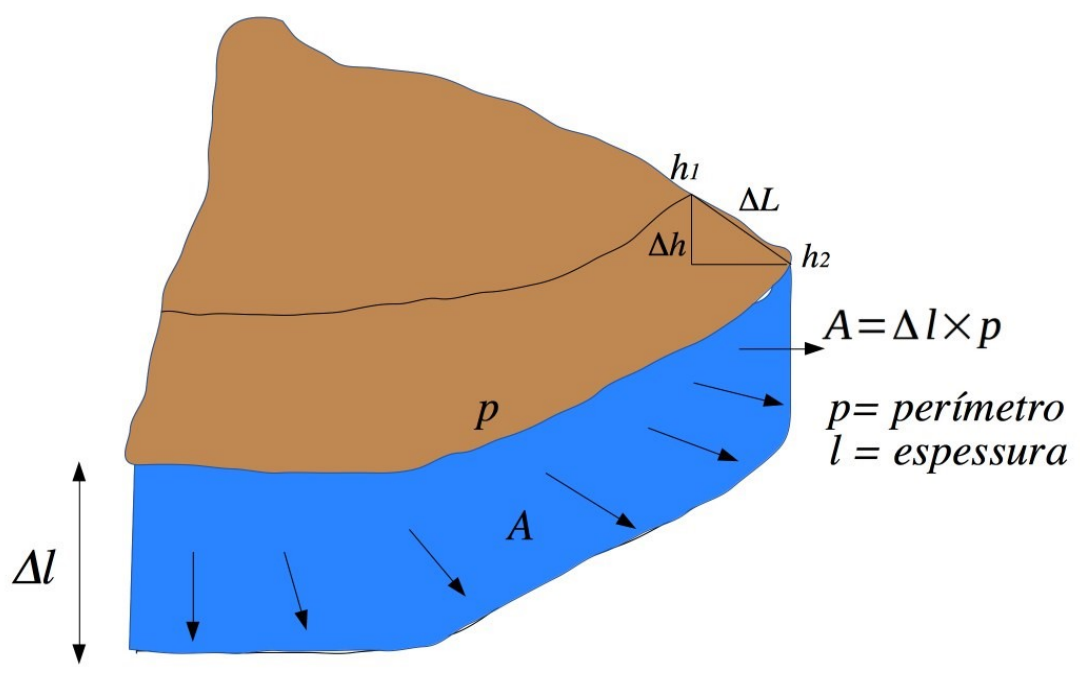

Figura 18. Esquema de aplicação da Lei de Darcy para estimativa da recarga lateral devida ao Chimborazo e Igualata. As setas representam a direção do fluxo da água. 


\subsection{Coleta de amostras de água}

Um total de 15 amostras foram coletadas na área de estudo (7 poços e 8 nascentes), distribuídas entre Llío, Guano, Cubijíes e Riobamba, (Figura 19).

$\mathrm{Na}$ ocasião, foram priorizados os poços de abastecimento público, em funcionamento, localizados nas regiões de Llío e Riobamba. Os critérios adotados para a seleção destas captações incluíram: i) aspectos construtivos dos poços e possibilidade de coleta; ii) localização geográfica de acordo com o Chimborazo (mais próximos ou mais distantes do vulcão); iii) diferentes formações geológicas captadas, conforme se observa nas descrições dos perfis litológicos.

As nascentes, por sua vez, foram selecionadas de acordo com os seguintes condicionantes: i) distribuição espacial na área de estudo, de forma a obter um conjunto de dados representativos; ii) acesso ao local; iii) possibilidade de coleta.

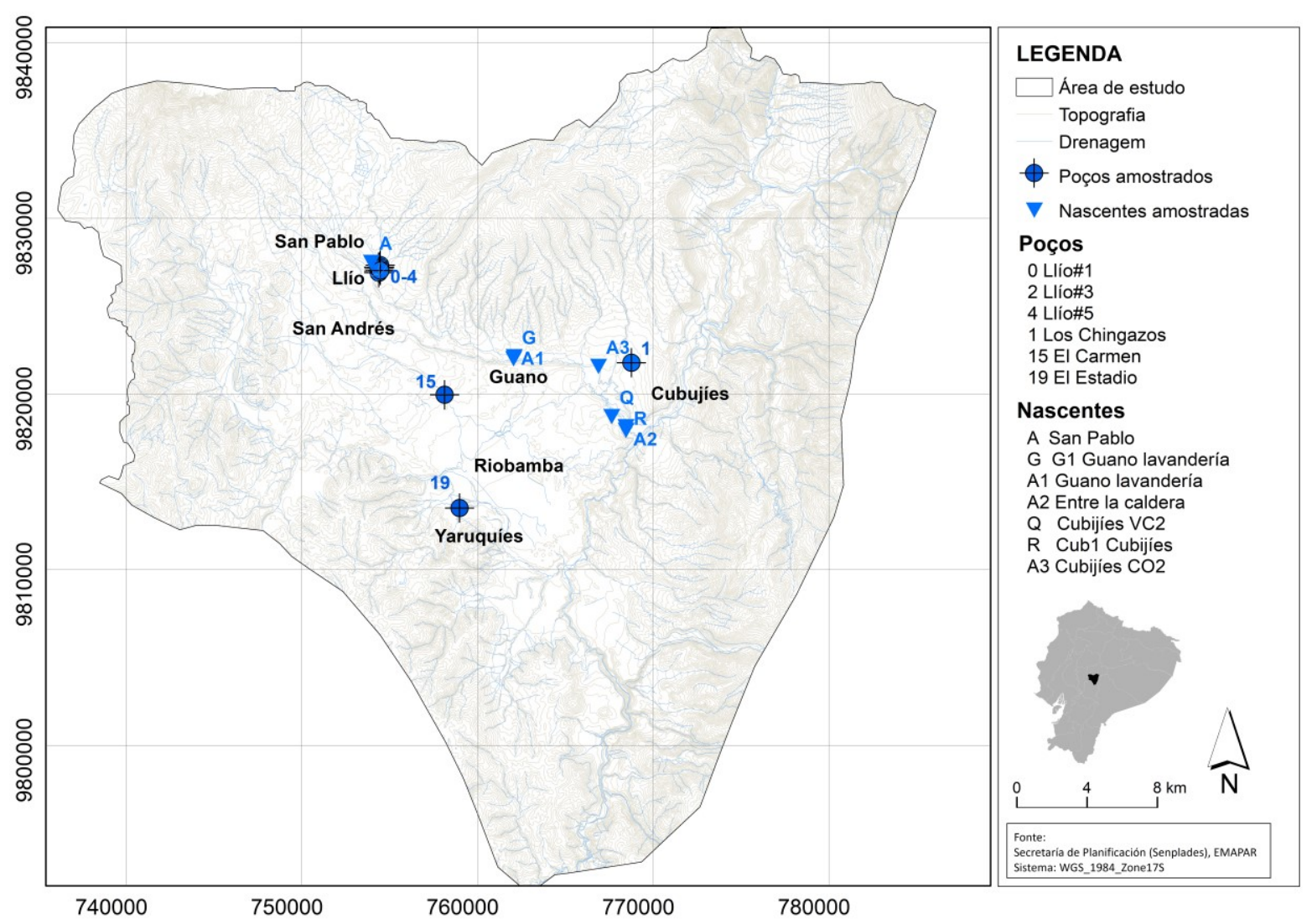

Figura 19. Pontos de coleta e amostragem de água na campanha realizada em agosto/2016. 


\subsubsection{Análises químicas}

As amostras de água dos poços e nascentes, destinadas às análises químicas, foram coletadas mediante uma campanha de amostragem (agosto/2016).

A coleta se procedeu a partir das próprias bombas instaladas nos poços, com purga prévia para a remoção de água estagnada (05-10 minutos de bombeamento), conforme os procedimentos descritos (USEPA,1985).

Posteriormente, as amostras foram filtradas em membranas de acetato celulose $(0,45 \mu \mathrm{m})$, em laboratório, com o auxílio de uma bomba a vácuo de bancada e, em seguida, acondicionadas em frascos de polietileno, acidificadas (análise de cátions), mantidas em geladeira a temperatura inferior $4^{\circ} \mathrm{C} \mathrm{e}$ encaminhadas ao laboratório para análise química.

Os parâmetros analisados incluíram os compostos nitrogenados $\left(\mathrm{NH}_{4}{ }^{+}\right.$, $\mathrm{NO}_{2}^{-}$e $\left.\mathrm{NO}_{3}{ }^{-}\right)$, cátions $\left(\mathrm{Ca}^{2+}, \mathrm{Mg}^{2+}, \mathrm{K}^{+}, \mathrm{Na}^{+}, \mathrm{Li}^{+}\right)$e ânions $\left(\mathrm{Br}^{-}, \mathrm{Cl}^{-}, \mathrm{F}^{-}, \mathrm{HPO}_{4}{ }^{2-}, \mathrm{SO}_{4}{ }^{2-}\right)$ Estas análises foram efetuadas no laboratório do Centro de Pesquisa de Águas Subterrâneas (CEPAS), do IGc-USP. Os procedimentos de preservação da amostra, metodologias analíticas e técnicas são expressas na Tabela 5. Métodos analíticos adotados para a determinação dos parâmetros em amostras de água.

Tabela 5. Métodos analíticos adotados para a determinação dos parâmetros em amostras de água.

\begin{tabular}{cccc}
\hline Parâmetro & Preservação & Método/Técnica & Laboratório \\
\hline $\mathrm{Ca}^{2+}, \mathrm{Mg}^{2+}, \mathrm{Li}^{+}, \mathrm{Br}^{-}$ & $\mathrm{HNO}_{3}^{-}$ & Espectrofotometria & CEPAS/USP \\
$\mathrm{Na}^{+}, \mathrm{K}^{+}$ & $\mathrm{HNO}_{3}^{-}$ & Fotometria de chama & CEPAS/USP \\
$\mathrm{Cl}^{-}, \mathrm{F}^{-}, \mathrm{HPO}_{4}^{-2}, \mathrm{NO}_{2}^{-} \mathrm{e}$ & Resfriamento & Cromatografia iônica & CEPAS/USP \\
$\mathrm{NO}_{3}^{-}, \mathrm{SO}_{4}^{-2}$ & & & \\
\hline
\end{tabular}

Além dessas espécies químicas, foram determinados, in situ, $\mathrm{pH}$, condutividade elétrica e temperatura das águas através de uma sonda multiparâmetros da marca Hydrolab, modelo HL4 e sensores YSI 599870-01 com precisão de 0 a 100: $+-0,5 \%$ da leitura ou $0,0001 \mathrm{mS} / \mathrm{cm} ; 100$ até $200: \pm 1 \%$ da leitura para condutividade e -5 até $35^{\circ} \mathrm{C} /+-0,01^{\circ} \mathrm{C} ; 35$ até $50^{\circ} \mathrm{C} / \pm 0,05^{\circ} \mathrm{C}$ para 
temperatura. Sensor de pH YSI 599705 com precisão: $\pm 0,1$ unidades de $\mathrm{pH} \pm 0,2$ unidades de $\mathrm{pH}$ para qualquer temperatura.

Outro parâmetro medido em campo foi a alcalinidade total, expressa em $\mathrm{mg} / \mathrm{L}$ de $\mathrm{CaCO}_{3}$. A técnica adotada foi a titulação volumétrica, utilizando-se de ácido sulfúrico $0,2 \mathrm{~N}$, padronizado previamente com $\mathrm{Na}_{2} \mathrm{CO}_{3}$, no laboratório do Centro de Investigação e Controle Ambiental da Escola Politécnica Nacional (CICAM), indicadores misto e fenolftaleína e de uma bureta de vidro com torneira, graduada de $50 \mathrm{~mL}$, acoplada a um suporte metálico (Figura 20).

\subsubsection{Tratamento dos dados}

Os resultados das análises químicas foram submetidos ao controle de qualidade através do cálculo do balanço iônico e de amostras duplicatas. $O$ cálculo do balanço iônico e o envio de amostras duplicatas consiste em procedimentos mais comuns adotados para avaliar a reprodutibilidade dos resultados, além de quantificar possíveis erros durante a execução das análises.

O balanço iônico foi efetuado em todas as amostras coletadas em campo, de modo a garantir que o erro esteja dentro do limite permitido, geralmente entre $\pm 10 \%$. A porcentagem do erro do balanço iônico, para todas as amostras totais, foi calculada a partir dos valores dos ânions e cátions, em miliequivalentes, segundo a equação 9, proposta por Custodio \& Llamas, 2001.

$$
\text { Erro }(\%)=\frac{\sum \text { cátions }-\sum \text { ânions }}{\sum \text { cátions }+\sum \text { ânions }} \times 100
$$

Com o intuito de caracterizar quimicamente as águas subterrâneas e estabelecer uma evolução hidroquímica da área utilizou-se o diagrama triangular de Piper a partir do software Aquachem, versão 3.7, da Schlumberger Water Services. As concentrações dos íons maiores na água foram convertidas em miliequivalentes por litro (meq/L) e dispostas no diagrama, calculando-se as porcentagens em relação à soma de cátions e ânions de cada amostra. 
Procedeu-se também a análise estatística convencional (média aritmética simples e desvio padrão) dos parâmetros físico-químicos $(\mathrm{pH}$, Eh, temperatura, condutividade elétrica), além dos cátions e ânions.
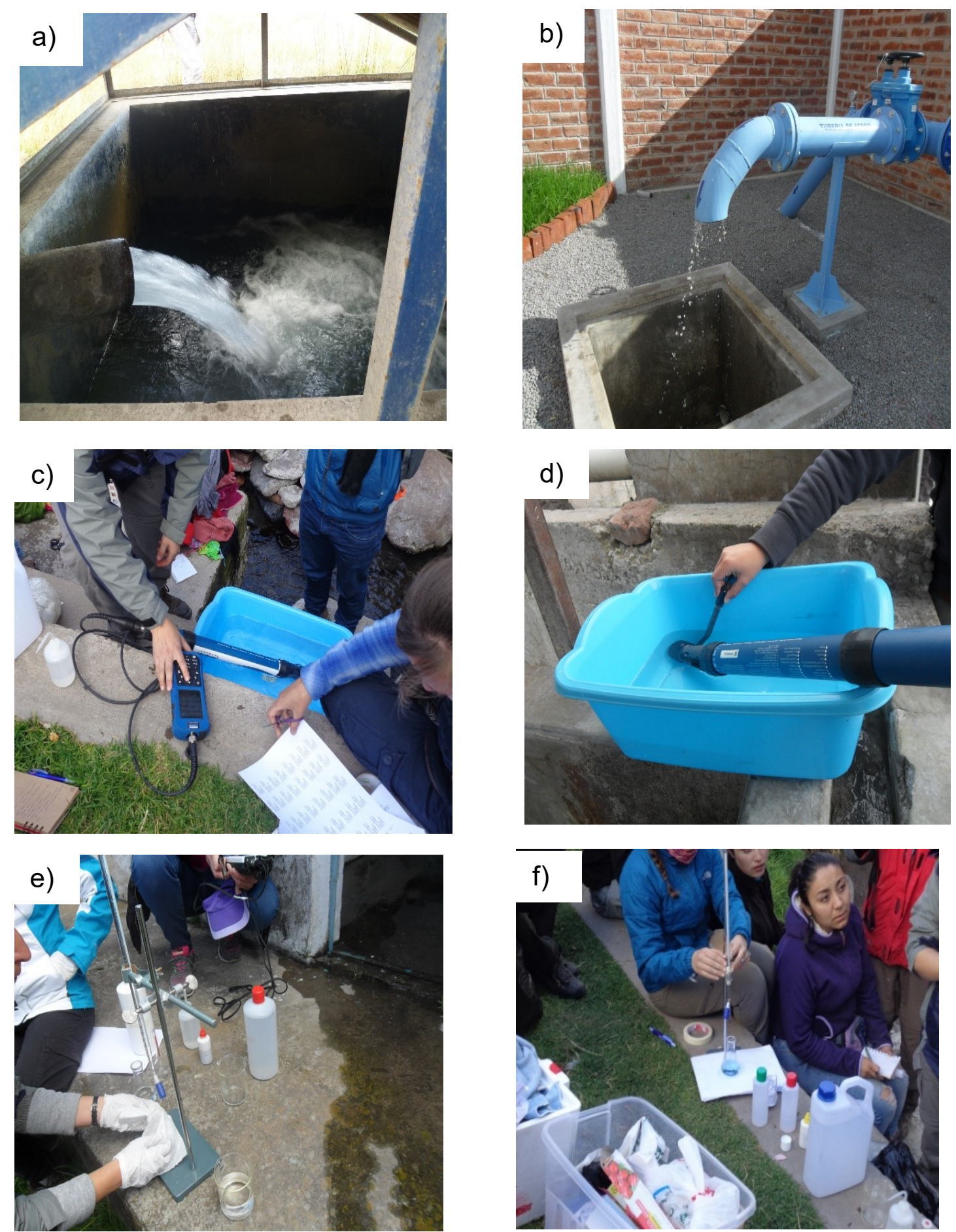

Figura 20. Procedimentos de coleta e preservação de amostras: Purga e coleta $(a, b)$, medição dos parâmetros físico-químicos $(c, d)$ e titulação volumétrica (e, f). 


\subsection{Uso dos isótopos ${ }^{2} \mathrm{H}$ e ${ }^{18} \mathrm{O}$ na identificação da origem da água}

Os isótopos estáveis usados nesta pesquisa foram os de hidrogênio, ${ }^{1} \mathrm{H}$ e ${ }^{2} \mathrm{H}$ (deutério ou $\mathrm{D}$ ), cujas abundâncias na natureza são de 99,98\% e 0,015\%, respectivamente, e de oxigênio, ${ }^{16} \mathrm{O}$ e ${ }^{18} \mathrm{O}$, com $99,79 \%$ e 0,20\% de abundância, respectivamente.

Os isótopos ${ }^{2} \mathrm{H}$ e ${ }^{18} \mathrm{O}$ são os mais utilizados em estudos das águas subterrâneas por fazerem parte da própria molécula da água. No entanto, por se tratarem de elementos cujo número atômico é pequeno, possuem uma composição isotópica variável devido aos efeitos de fracionamento decorrentes de fenômenos físicos e químicos na natureza. O fracionamento isotópico ocorre com maior frequência quando não há um equilíbrio entre as fases líquida e gasosa, isto é, quando a formação de vapor é contínua (Dixon \& Chiswell, 1994).

Segundo Moser \& Stichler (1980), a distribuição dos isótopos de oxigênio e hidrogênio e os seus conteúdos na água são determinados por diferentes processos no ciclo hidrológico. A principal razão para essas variações é que a pressão de vapor d'água é mais rica em ${ }^{1} \mathrm{H} \mathrm{e}{ }^{16} \mathrm{O}$ do que a água residual, onde há a maior predominância dos isótopos pesados $\left({ }^{2} \mathrm{H} \mathrm{e}{ }^{18} \mathrm{O}\right)$. Como resultado disso, em todas as fases de transição, como na condensação ou evaporação, o fracionamento ocorre mudando o conteúdo isotópico.

Esses dois isótopos são amplamente empregados em estudos que envolvem a determinação da origem das águas subterrâneas, a avaliação da taxa de recarga em aquíferos livres, os processos de dispersão e o tempo de trânsito de contaminantes na zona saturada e não-saturada. Pode-se dizer que as águas subterrâneas guardam a composição isotópica de sua origem por longos períodos, da ordem de milhares de anos, desde que não sejam expostas a temperaturas superiores a $80^{\circ} \mathrm{C}$ (Gat, 1980).

Os valores de $\delta^{18} \mathrm{O}$ e $\delta^{2} \mathrm{H}$ provenientes da precipitação, da água do solo e das águas subterrâneas são utilizados para identificar as origens e caminhos de 
percolação da recarga, não apenas em aquíferos livres, como também na zona não-saturada (Komor \& Emerson, 1994); (Mathieu \& Bariac, 1996); (Landon, Delin, Komor, \& Regan, 2000); (Hosono, et al., 2011); (Millot, Innocent, Négrel, \& San Juan, 2011).

Komor e Anderson (1994) atestam que a concentração do soluto e seu tempo de trânsito na zona não-saturada é muito dependente dos caminhos que a água percorre no meio. A água que percola mais rapidamente, ao longo de caminhos preferenciais, apresenta um menor tempo de contato com o solo e, portanto, menores são as chances de se atingir o equilíbrio químico solo-rochaágua. Um caminho de maior percolação, leva a uma maior interação rocha-água e uma possível modificação do conteúdo químico e naturalmente isotópico.

Em muitos casos a composição isotópica das águas subterrâneas reflete bem a média da composição isotópica da chuva na área de recarga. Por esses motivos, as águas dos aquíferos livres são muitas vezes usadas para caracterizar o conteúdo isotópico da chuva de uma determinada região. Entretanto, a correlação entre a composição isotópica de origem pluvial e das águas subterrâneas derivada desta nem sempre é perfeita. Há casos onde as águas subterrâneas são mais enriquecidas ou mais empobrecidas em isótopos pesados. Esta distorção tende a tornar-se maior em climas mais áridos, normalmente no sentido de um enriquecimento em isótopos pesados.

As mudanças na composição isotópica de ${ }^{2} \mathrm{H} \mathrm{e}{ }^{18} \mathrm{O}$ das precipitações que ocorrem em lugares distintos são causadas por diferenças na altitude, latitude e proximidade do oceano. $\mathrm{O}$ conteúdo de ${ }^{2} \mathrm{H}$ e ${ }^{18} \mathrm{O}$ nas águas subterrâneas depende do mecanismo e do tempo da recarga e, principalmente, da distribuição da chuva com respeito à evapotranspiração. Considerando uma escala plurianual, espera-se que as águas subterrâneas representem a média local das condições climáticas e qualquer mudança significativa nestas condições, como períodos anormais de seca ou de chuvas, alterará os valores de $\delta^{18} \mathrm{O}$ e $\delta^{2} \mathrm{H}$. 
Durante as mudanças de fase da água no ciclo hidrológico (por exemplo: evaporação, condensação e fusão) ocorre o fracionamento dos isótopos estáveis (Clark \& Fritz, 1997). Este fracionamento é controlado pela diferença de massa de isótopos e pela temperatura. O processo de fracionamento pode ser representado por um fator de fracionamento isotópico $\alpha$ que relaciona as razões isotópicas nas diferentes fases, conforme a equação abaixo:

$$
\alpha=\frac{\left(O^{18} / 0^{16}\right)_{\text {fase } A}}{\left(0^{18} / 0^{16}\right)_{\text {fase } B}}
$$

Como resultado do processo de fracionamento, a água desenvolve uma composição isotópica característica, indicativa de sua fonte (Clark \& Fritz, 1997).

As composições isotópicas de oxigênio e hidrogênio são apresentadas como a relação entre a razão medida na amostra e a razão de um padrão de referência, mundialmente difundido e aceito, utilizando-se a notação de $\delta$. Os valores de $\delta$ são expressos em partes por mil (\%o) em relação a um padrão de referência internacional, de acordo com a equação:

$$
\delta^{18} O_{\text {amostra }}=\left(\frac{0^{18} / O^{16} \text { amostra }}{O^{18} / 0^{16} \text { padrão }}-1\right) \times 1000 \% \text { VSMOW }
$$

Onde, VSMOW (Viena STANDAR Mean Ocean Water) é o padrão de referência aceito internacionalmente, no caso do oxigênio e hidrogênio.

Segundo Clark e Fritz (1997), resultados positivos de $\delta^{18} \mathrm{O}$ e $\delta^{2} \mathrm{H}$ em uma determinada amostra indicam que há maior enriquecimento nos isótopos ${ }^{18} \mathrm{O} \mathrm{e}$ ${ }^{2} \mathrm{H}$ em relação ao padrão de referência (amostras enriquecidas). Da mesma forma, resultados negativos de $\delta^{18} \mathrm{O}$ e $\delta^{2} \mathrm{H}$ significam que há um empobrecimento da amostra em ${ }^{18} \mathrm{O}$ e ${ }^{2} \mathrm{H}$, quando comparada ao padrão de referência (amostras empobrecidas).

Os valores de $\delta^{18} \mathrm{O}$ e $\delta^{2} \mathrm{H}$ da água no ciclo hidrológico são modificados por processos meteorológicos. O ciclo global é considerado, praticamente, em equilíbrio dinâmico, onde cada etapa (evaporação, condensação/chuva, escoamento, entre outros) é responsável por fracionar isotopicamente o ${ }^{18} \mathrm{O}$ e 0 
${ }^{2} \mathrm{H}$, conferindo uma assinatura isotópica característica para cada reservatório (Maldener, 2010).

Durante os processos de condensação e evaporação os isótopos se tornam, progressivamente, empobrecidos e enriquecidos em relação aos isótopos pesados $\left({ }^{18} \mathrm{O}\right.$ e $\left.{ }^{2} \mathrm{H}\right)$. Quando a água evapora da superfície dos oceanos, o vapor d'água é enriquecido em ${ }^{16} \mathrm{O}$ e ${ }^{1} \mathrm{H}$ uma vez que $\mathrm{H}_{2}{ }^{16} \mathrm{O}$ apresenta pressões de vapor maiores que moléculas de água de $\mathrm{H}_{2}{ }^{18} \mathrm{O}$. Desta forma, os valores de $\delta^{18} \mathrm{O}$ e $\delta^{2} \mathrm{H}$ das massas de ar acima dos oceanos são negativos em relação ao SMOW, enquanto as águas da chuva provenientes destas massas de ar são, relativamente, enriquecidas em ${ }^{18} \mathrm{O}$ e ${ }^{2} \mathrm{H}$ (Stille \& Shields, 1997).

A razão isotópica de oxigênio e hidrogênio da precipitação é afetada, predominantemente, pela temperatura. Em regiões localizadas em maiores latitudes, geralmente mais frias, as águas das chuvas possuem razões isotópicas mais negativas em relação às zonas equatoriais e tropicais. As regiões costeiras são mais enriquecidas em relação a regiões continentais, geralmente mais frias e com forte variação sazonal. As regiões com maior altitude recebem também chuvas mais empobrecidas (Santos \& Gatsmans, 2016); (Marqueto, Simões, Cassassa, Introne, \& Dos Santos, 2015).

Craig (1961) definiu uma reta meteórica baseada em dados de todo o mundo. Nesta reta, o autor observou que os valores de $\delta^{18} \mathrm{O}$ e $\delta^{2} \mathrm{H}$ das precipitações estão linearmente relacionados na denominada reta meteórica global ((Global Meteoric Water Line (GMWL)) mediante a equação:

$$
\delta^{2} \mathrm{H}=8 \delta^{18} \mathrm{O}+10(\% \text { VSMOW })
$$

Posteriormente, Rozanski et al. (1993) definiram a reta meteórica global mais precisa que a publicada por Craig (1961), corrigida para VSMOW, com base em dados provenientes de 219 estações da rede Global Network of isotopes in Precipitation (GNIP), Agência Internacional de Energia Atômica (AIEA). Assim, a reta meteórica global é dada pela equação:

$$
\delta^{2} \mathrm{H}=8,13 \delta^{18} \mathrm{O}+10,8(\% \text { VSMOW) }
$$


Segundo Clark \& Fritz (1997), em estudos isotópicos regionais e locais é importante comparar os dados das águas superficiais e subterrâneas com uma reta meteórica local e com a média global de várias retas meteóricas locais (GMWL).

\subsubsection{Análise de $\delta^{2} H$ e $\delta^{18} \mathrm{O}$}

Em agosto de 2016, foram coletadas 17 amostras de água de poços e nascentes, distribuídas nas seguintes localidades: Llío (4 amostras), Guano (2 amostras), Riobamba (5 amostras) e Cubijíes (6 amostras).

Para a determinação de $\delta^{2} \mathrm{H}$ e $\delta^{18} \mathrm{O}$, foram amostrados $25 \mathrm{~mL}$ de água, armazenados em frascos PET (polyethylene terephthalate) previamente lavados com a própria amostra. Os frascos foram vedados com batoque e com a preocupação de não deixar bolhas, de modo a impedir o fracionamento isotópico pelo contato atmosférico. Em seguida, as amostras foram mantidas sob a temperatura ambiente.

As análises destes dois isótopos foram processadas no Laboratório de Isótopos Estáveis do Centro de Pesquisas de Águas Subterrâneas (CEPAS) do Instituto de Geociências da USP, a partir do equipamento Cavity Ringdown Spectrometer $\mathrm{L} 2130$-i Isotopic $\mathrm{H}_{2} \mathrm{O}$, marca Picarro. A incerteza dos resultados reportados pelo laboratório é de $\pm 0,09 \%$, para o $\delta^{18} \mathrm{O}$, e de $\pm 0,9 \%$, para $\delta^{2} \mathrm{H}$.

Todas as medidas obtidas foram processadas de acordo com procedimentos da IAEA \& USGS (2013). Os resultados de $\delta^{18} \mathrm{O}$ e $\delta^{2} \mathrm{H}$ são expressos segundo a equação:

$$
\delta \mathrm{X}(\% 0)=(\text { Rs } / \text { Rst }-1) * 1000
$$

Onde $\mathrm{X}$ representa ${ }^{2} \mathrm{H}$ ou ${ }^{18} \mathrm{O}$; Rs indica as razões ${ }^{2} \mathrm{H} /{ }^{1} \mathrm{H}$ e ${ }^{18} \mathrm{O} /{ }^{16} \mathrm{O}$; e Rst o padrão de referência, respectivamente (VSMOW). 


\subsubsection{Instalação de coletor e amostragem de água de chuva.}

A coleta de água de chuva para análises de $\delta^{2} \mathrm{H}$ e $\delta^{18} \mathrm{O}$ foi realizada entre 14 de outubro de 2016 e 15 de maio de 2017, em três diferentes locais: um situado nas dependências da Escola Politécnica de Chimborazo (ESPOCH/Riobamba), outro no centro da cidade de Guano e o terceiro, em llapo (Figura 21).

Alguns critérios foram adotados na seleção dos locais para a instalação dos coletores, dentre os quais destacam-se: i) locais de fácil acesso para coleta e que se apresentasse seguro; ii) locais abertos e distantes de árvores e edificações; iii) locais em que o coletor pudesse ser colocado em altura suficiente para minimizar o efeito da ressuspensão do solo durante a chuva; e iv) locais próximos aos pluviômetros da rede do INAMHI (Figura 21).

Um total de 24 amostras água de chuva foi coletado todo dia 15 de cada mês, em um garrafão de polietileno de alta densidade (HDPE), enterrado, com capacidade de $2 \mathrm{~L}$, acoplado a uma estrutura metálica, tipo tripé. Na extremidade desta estrutura metálica há um cilindro de $2 \mathrm{~cm}$ de diâmetro, que liga a mangueira de borracha ao garrafão, de modo a impedir o contato da água amostrada com a atmosfera (Figura 21). A construção deste aparato seguiu as recomendações indicadas pelo Instituto de Pesquisa para o Desenvolvimento da França, no Equador (IRD). Antes da instalação dos coletores, os galões e conexões foram previamente lavados com água destilada e protegidos com filme plástico (Figura 21). 


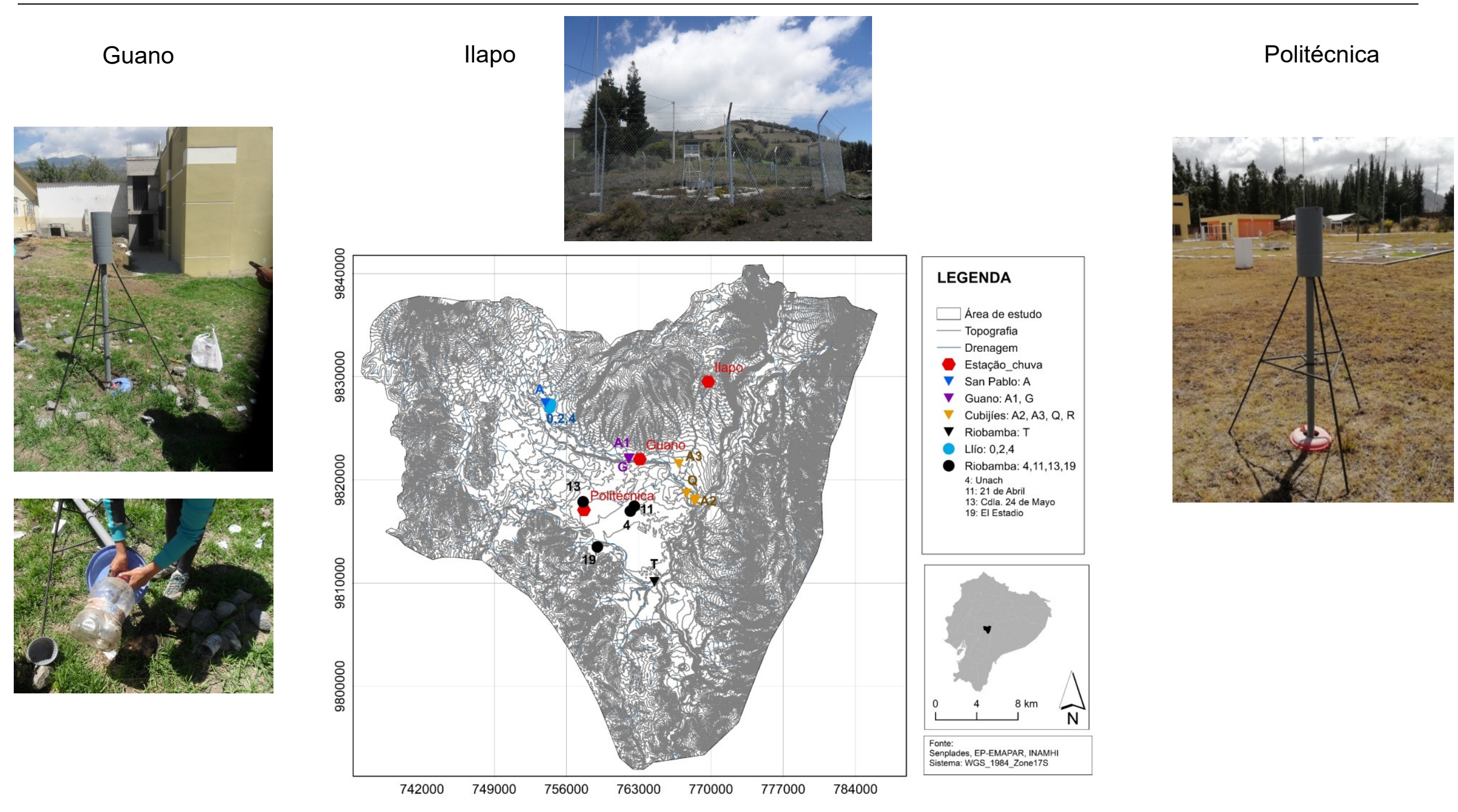

Figura 21. Pontos de coleta de água de chuva, poços e nascentes para análises de isótopos $\delta^{2} H$ e $\delta^{18} \mathrm{O}$. 


\subsection{Modelo Hidrogeológico Conceitual}

O modelo conceitual de circulação das águas subterrâneas na área de estudo foi estabelecido a partir da análise dos perfis construtivos, litológicos, geológicos, além das perfilagens geofísicas dos poços selecionados. Adicionalmente, foram determinados os dados hidráulicos mediante a interpretação dos testes de bombeamento existentes (níveis estático e dinâmico, vazão, condutividade hidráulica e transmissividade). As análises dos elementos supracitados resultaram na elaboração de mapas potenciométricos, seções hidrogeológicas, bem como no cálculo dos parâmetros hidráulicos do aquífero.

Os mapas potenciométricos foram elaborados a partir dos valores das cargas hidráulicas dos poços cadastrados existentes na $\mathrm{BBRCH}$. As cargas foram calculadas subtraindo-se as cotas das bocas dos poços e os valores do níveL estático (NE), registrados na época da instalação dos mesmos. Além desses valores, destacam-se também as medidas de NE realizadas pela EPEMAPAR nos anos 2012 e 2014 e os valores de NE registrados nas etapas de campo em novembro de 2016, de janeiro a maio de 2017 e em janeiro de 2018. Foram consideradas, também, as cotas das nascentes existentes na região, cujos valores foram extraídos a partir das altitudes topográficas das nascentes cadastradas pela EP-EMAPAR e das obtidas no campo em novembro de 2016.

A interpolação das cargas hidráulicas e a geração das linhas equipotenciais foram efetuadas com o auxílio do Programa ArcGis, versão 10.2.1, da ESRI, utilizando-se o método geoestatístico da Krigagem. Em seguida, foram determinadas as direções preferenciais de fluxo das águas subterrâneas no aquífero, o gradiente hidráulico (i) e a sua velocidade $\left(V_{r}\right)$, parâmetros calculados pela equação de Darcy.

Os parâmetros condutividade hidráulica (K) e transmissividade (T) foram calculados mediante cinco testes de bombeamento (etapa de rebaixamento) em poços tubulares localizados em Llío, Riobamba e Yaruquíes.

Foram selecionados testes com tempo de bombeamento de 72 horas. Salienta-se que as medidas de rebaixamento versus tempo foram efetuadas no próprio poço. As interpretações dos testes de bombeamento e o cálculo dos valores dos parâmetros hidráulicos supracitados foram executadas segundo a metodologia do autor De Miguel Fernandez (1999). 
Três seções hidrogeológicas, de direções NO-SE e E-O, foram elaboradas fundamentalmente com 0 intuito de fornecer uma visão espacial das unidades/formações geológicas que compõem os aquíferos da área de estudo. Assim, os dados utilizados (por exemplo: geológicos, geofísicos, nível d'água) foram correlacionados, obtendo-se, assim, os possíveis contatos e espessuras das principais formações geológicas, além das feições morfológicas, divisores de água e dos principais cursos d’água.

\subsection{Técnicas de zoneamento para a gestão de recursos hídricos.}

\subsubsection{Zoneamento da área para fins de gestão integrada de recursos hídricos}

O zoneamento descrito na seção 5.2 foi levado em consideração para definir o plano de gestão de recursos hídricos na área de estudo. Em cada zona definida, estimou-se: i) as demandas de água para os diferentes usos, considerando as outorgas que constam dos arquivos da SENAGUA até o ano 2010 e as estimativas das necessidades hídricas de cada tipo de cultura; e ii) as ofertas de água, considerando as vazões superficiais dos principais rios da BBRCH (Guano, Chimborazo, Chibunga) e as vazões subterrâneas (vazão de explotação dos poços e nascentes).

A demanda de água para fins agrícolas foi assumida de acordo com as necessidades de irrigação estabelecidas pela Organização das Nações Unidas para a Alimentação e Agricultura (FAO, 1991) para as diferentes culturas (milho, batata, cereais, vegetais e frutas). Para cada cultura foi considerada a precipitação (mínima e máxima) requerida para um hectare de cultivo, bem como os dias (mínimos e máximos) necessários para cada safra (Tabela 6). 
Tabela 6. Demanda de água para fins agrícolas segundo a FAO (1991).

\begin{tabular}{lccccc}
\hline & & & & Demanda & $\begin{array}{c}\text { Demanda } \\
\text { máx. }\end{array}$ \\
Cultura & $\begin{array}{c}\text { Demanda } \\
\text { mín. água } \\
\text { (mm/safra) }\end{array}$ & $\begin{array}{c}\text { Demanda } \\
\text { máx. água } \\
(\mathbf{m m} / \mathbf{s a f r a )}\end{array}$ & $\begin{array}{c}\text { Número de } \\
\text { safras/ano }\end{array}$ & $\begin{array}{c}\text { mín. água } \\
\text { 1hectare } \\
\left(\mathbf{m}^{3} / \mathbf{a n o}\right)\end{array}$ & $\begin{array}{c}\text { água } \\
\text { 1hectare } \\
\left(\mathbf{m}^{3} / \mathbf{a n o}\right)\end{array}$ \\
\hline Milho & 500 & 800 & 2 & 10000 & 16000 \\
Batata & 500 & 700 & 2 & 10000 & 14000 \\
Cereais & 450 & 650 & 2 & 9000 & 13000 \\
Vegetais & 350 & 500 & 2 & 10500 & 15000 \\
Frutais & 400 & 800 & 2 & 8000 & 16000 \\
\hline
\end{tabular}

Posteriormente e com ajuda do Arcgis 10.2.1 foram calculados os hectares de cada cultura na área de estudo, com os quais obteve-se a demanda mínima e a máxima de cada cultura, em cada zona (Figura 22).

As demandas para pastagens naturais foram excluídas da estimativa, uma vez que estas são satisfeitas pela precipitação. As exigências de água para dessedentação de animais e cultivo de peixes, não foram estimados devido à falta de informações.

As demandas domésticas urbanas atuais e futuras das zonas Z6 e Z7 (zonas urbanas de Riobamba e Guano) foram estimadas considerando o censo realizado pelo INEC, em 2010, e a taxa de crescimento demográfico de 2,8\% (INEC, 2010) até 2040 (Tabela 7). 

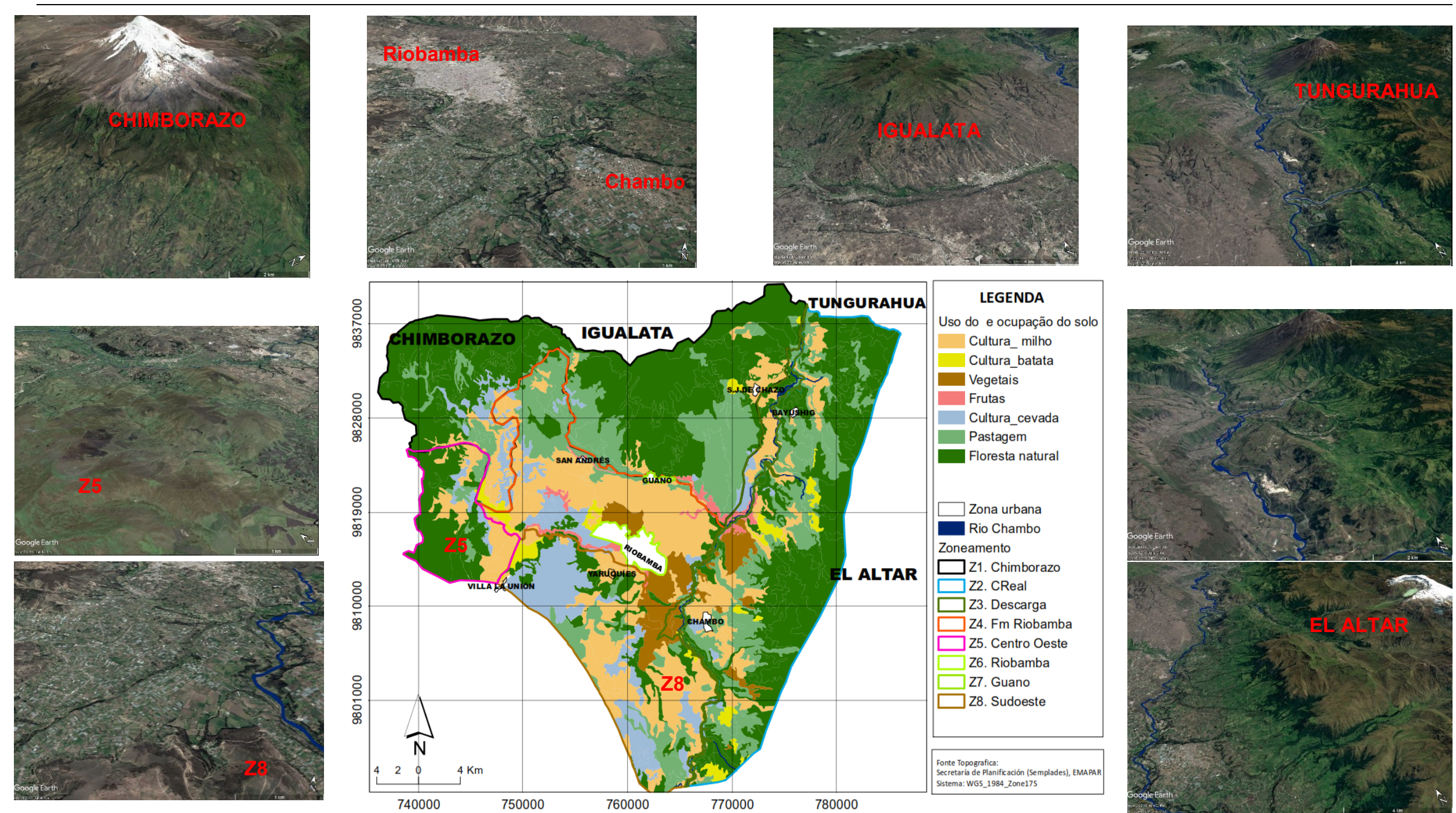

Figura 22. Demanda de água de acordo com o uso de terras agrícolas nas áreas estabelecidas na $B B R C H$. 
Tabela 7. Crescimento demográfico e projeções populacionais nas zonas urbanas da BBRCH (INEC, 2010).

\begin{tabular}{|c|c|c|c|}
\hline Ano & $\begin{array}{c}\text { Riobamba } \\
\text { (Habitantes) }\end{array}$ & $\begin{array}{c}\text { Guano } \\
\text { (Habitantes) }\end{array}$ & $\begin{array}{c}\text { Total } \\
\text { (Habitantes) }\end{array}$ \\
\hline 2010 & 225741 & 42851 & 280477 \\
\hline 2012 & 238559 & 43712 & 294685 \\
\hline 2013 & 245239 & 44149 & 302075 \\
\hline 2014 & 252106 & 44591 & 309663 \\
\hline 2015 & 259165 & 45037 & 317453 \\
\hline 2016 & 266421 & 45487 & 325451 \\
\hline 2017 & 273881 & 45942 & 333664 \\
\hline 2018 & 281550 & 46401 & 342096 \\
\hline 2019 & 289433 & 46866 & 350755 \\
\hline 2020 & 297537 & 47334 & 359646 \\
\hline 2021 & 305868 & 47808 & 368775 \\
\hline 2022 & 314433 & 48286 & 378150 \\
\hline 2023 & 323237 & 48768 & 387776 \\
\hline 2024 & 332288 & 49256 & 397662 \\
\hline 2025 & 341592 & 49749 & 407813 \\
\hline 2026 & 351156 & 50246 & 418237 \\
\hline 2027 & 360989 & 50749 & 428943 \\
\hline 2028 & 371096 & 51256 & 439936 \\
\hline 2029 & 381487 & 51769 & 451226 \\
\hline 2030 & 392169 & 52286 & 462821 \\
\hline 2031 & 403149 & 52809 & 474729 \\
\hline 2032 & 414437 & 53337 & 486958 \\
\hline 2033 & 426042 & 53871 & 499517 \\
\hline 2034 & 437971 & 54409 & 512417 \\
\hline 2035 & 450234 & 54953 & 525665 \\
\hline 2036 & 462841 & 55503 & 539271 \\
\hline 2037 & 475800 & 56058 & 553246 \\
\hline 2038 & 489123 & 56619 & 567600 \\
\hline 2039 & 502818 & 57185 & 582342 \\
\hline 2040 & 516897 & 57757 & 597485 \\
\hline
\end{tabular}


Posteriormente, foram usadas as estimativas de demanda doméstica por habitante calculadas por Mancheno (2010) para os dados do ano 2004 nas cidades de Riobamba, Guano e Chambo (0,21 m³/hab/dia). Considerou-se como limite inferior a vazão mínima indispensável para consumo humano. Esta vazão (100 m³/hab/dia) foi determinada pela Comissão Econômica para América Latina e Caribe (CEPAL, 2012).

A oferta de água na área de estudo foi considerada pelas vazões superficiais e subterrâneas de cada zona e para cada uso. Para estimar as vazões superficiais, foram feitas medições das vazões dos principais rios localizados a oeste do rio Chambo (Guano, Chimborazo e Chibunga). Foram definidos os períodos de maior e menor precipitação no ano (abril e junho). Neste período do ano 2017, foram medidas as vazões dos três rios em diferentes pontos através do método do flutuador. Esse método consistiu em determinar a velocidade de deslocamento de uma garrafa plástica (pet) de $125 \mathrm{ml}$ (sem rótulo, preenchida em $3 / 4$ de seu volume), medindo o tempo utilizado para o seu deslocamento em diferentes trechos dos rios com comprimentos conhecidos.

Para o cálculo das vazões dos rios, aplicou-se a equação:

$$
Q=c \times S \times V
$$

Onde: $Q$ é a vazão em $\mathrm{m}^{3} / \mathrm{s}$; $c$ é o coeficiente de correção para valor real; $S$ corresponde à área da seção; e $V$ é a velocidade de fluxo $(\mathrm{m} / \mathrm{s})$.

No caso dos rios Guano, Chimborazo e Chibunga, foram feitas as medições de velocidades de três a cinco vezes, para depois calcular a média de velocidade em cada trecho dos rios. O coeficiente de correção usado na medição de vazão com flutuador foi o valor médio de 0,75 (Valente \& Gomez, 2005). A Figura 23 mostra as vazões assim calculadas em cada trecho dos três rios.

O percurso de cada rio foi dividido em trechos cujos limites são os pontos onde a vazão do rio foi estimada. Foi assumido que a vazão superficial disponível da área por trecho entre dois pontos é a diferença das vazões estimadas em seus extremos. 


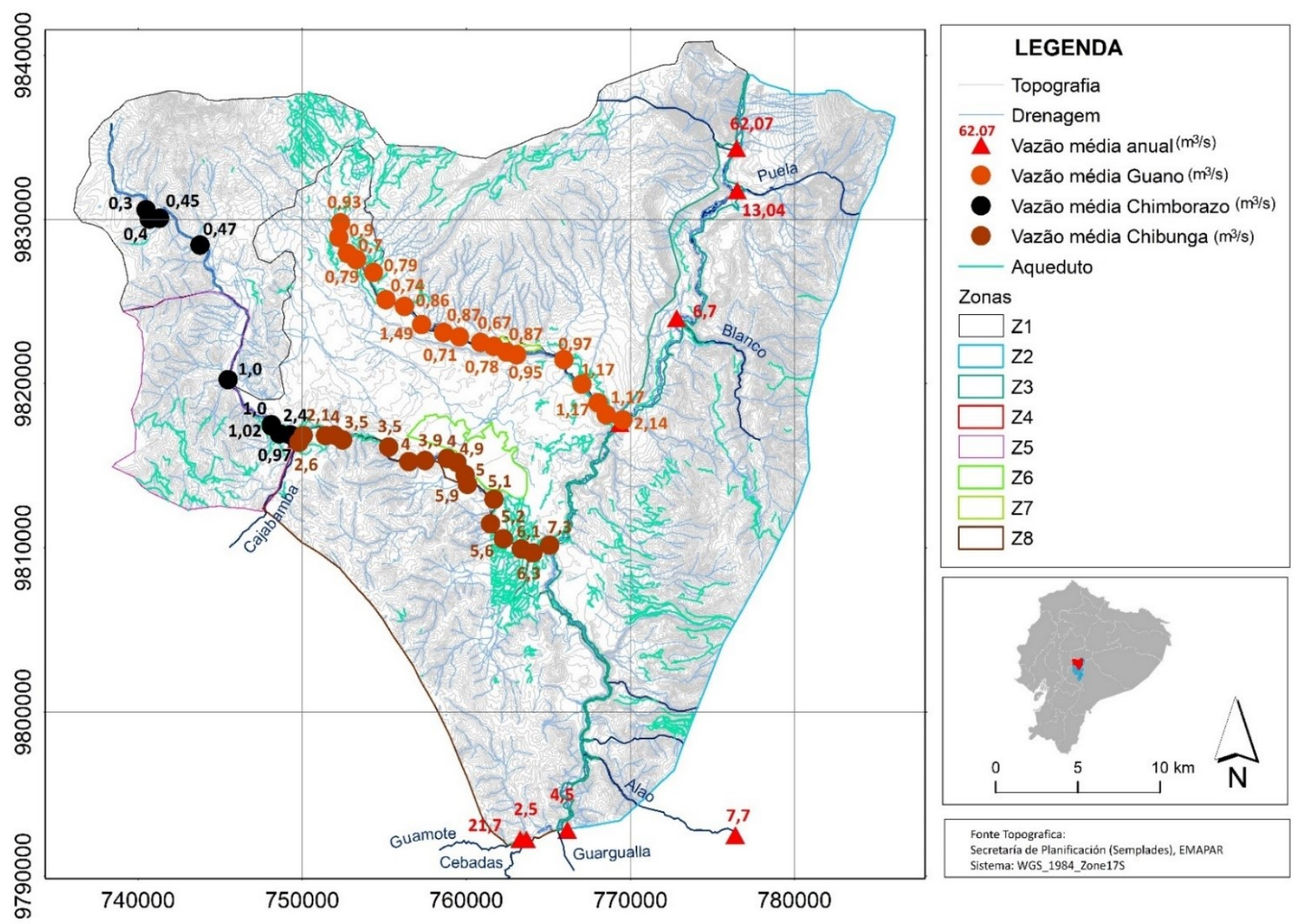

Figura 23. Vazões médias (nos períodos de abril e junho de 2017) para os diferentes trechos dos rios Guano, Chimborazo e Chibunga. Vazões médias anuais dos rios Cebadas, Guamote, Guargualla, Alao, Blanco e Puela (CNRH, 2007). 
A Figura 24 ilustra como foi calculada essa contribuição, onde as linhas azuis simbolizam os percursos do rio Guano e Chambo, os círculos ilustram os pontos onde foi estimada a vazão do rio junto com seus valores, as linhas pretas as contribuições ao rio devido aos afluentes e as setas a direção do fluxo superficial. Por exemplo, a contribuição da zona (Z1) à vazão do rio entre o primeiro ponto $\left(Q=0,79 \mathrm{~m}^{3} / \mathrm{s}\right)$ e o segundo $\left(Q=0,87 \mathrm{~m}^{3} / \mathrm{s}\right)$ é de $\Delta Q=0,08 \mathrm{~m}^{3} / \mathrm{s}$. A contribuição total da zona para o rio é a soma de todas as contribuições parciais dos trechos. É evidente que nem todas as contribuições ao rio provêm da Z1, por exemplo, entre o segundo e o terceiro ponto existe uma contribuição da Z4. Assim, este trecho com contribuições exclusivamente da Z4 foi excluído, já que não representa água superficial disponível na Z1. Existem também trechos com contribuições de duas zonas ( $Z 1$ e Z4), por exemplo entre os pontos com $Q=0,95$ $\mathrm{m}^{3} / \mathrm{s}$ e $\mathrm{Q}=1,17 \mathrm{~m}^{3} / \mathrm{s}$. Neste caso, e devido a não ter sido possível quantificar exatamente a contribuição de cada zona, a diferença de vazão entre os pontos $\left(\Delta Q=0,22 \mathrm{~m}^{3} / \mathrm{s}\right)$ foi dividida em duas $\left(\Delta Q_{1}=0,11 \mathrm{~m}^{3} / \mathrm{s}\right.$ e $\left.\Delta Q_{4}=0,11 \mathrm{~m}^{3} / \mathrm{s}\right)$ e estes valores foram atribuídos como vazão superficial disponível em cada zona. Observa-se que a vazão do rio em alguns trechos na jusante diminui, isto ocorre devido à existência de aquedutos ou canais de irrigação que aproveitam a drenagem, diminuindo a vazão do rio, estes trechos também foram excluídos (Tabela 8, Figura 23).

As vazões dos rios orientais foram obtidas do cadastro do Conselho Nacional de Recursos Hídricos (CNRH, 2007). Deste modo, foram obtidas as vazões médias anuais dos rios Cebadas, Guamote, Guargualla, Alao, Blanco e Puela (Figura 23). 


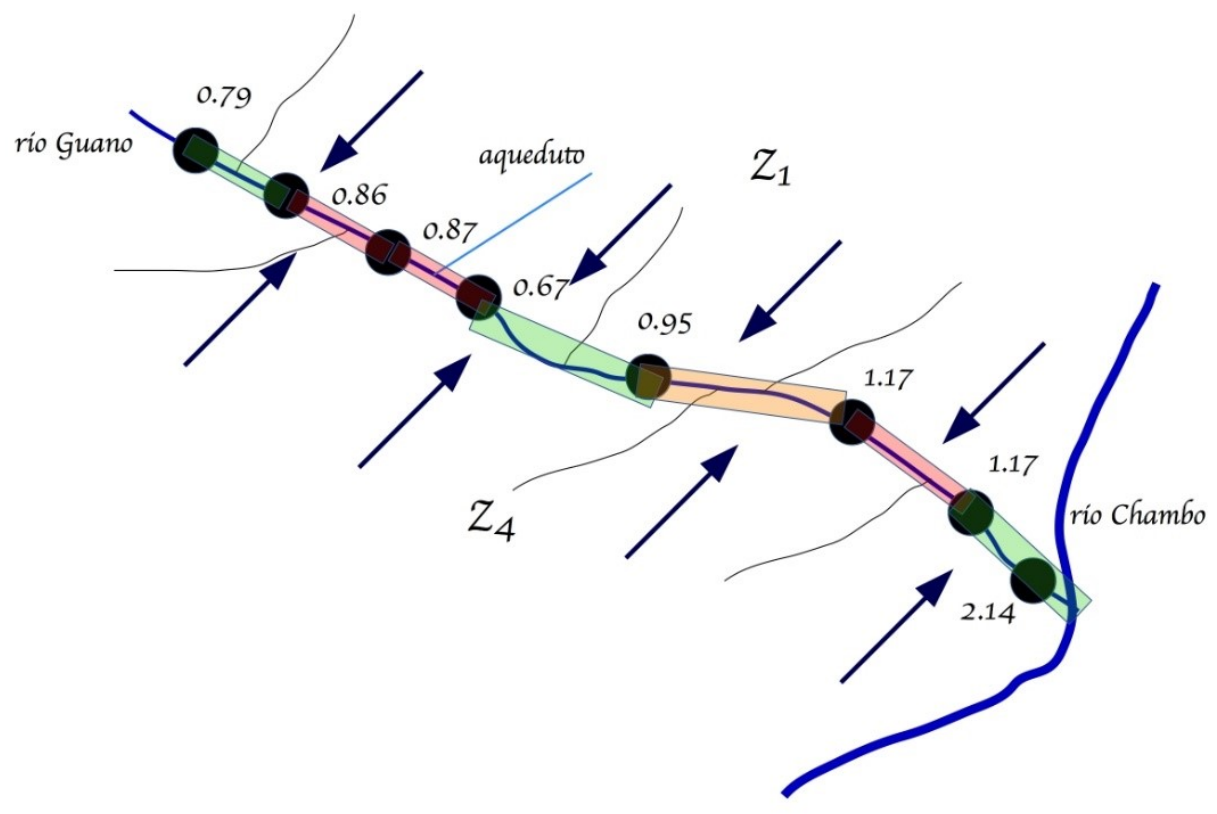

Figura 24. Estimativa da vazão superficial disponível na zona 1. As linhas azuis representam os rios Guano (dividido em trechos) e Chambo. Os valores correspondem às vazões medidas em cada ponto do rio, em $\mathrm{m}^{3} / \mathrm{s}$. As linhas cinzas representam afluentes do rio e as cores em cada trecho representam: vermelho, trecho com contribuição excluída; verde, trecho com contribuição considerada; e amarela trecho com contribuição dividida pela metade. 
Tabela 8. Localização e vazão média estimada (abril e junho 2017) em cada ponto do percurso do rio Guano. A última coluna representa as contribuições de água superficial da zona 1 para cada trecho do rio.

\begin{tabular}{|c|c|c|c|}
\hline UTM E & UTM N & $\begin{array}{c}\text { Q média } \\
\left(\mathrm{m}^{3} / \mathrm{s}\right)\end{array}$ & $\Delta Q\left(\mathrm{~m}^{3} / \mathrm{s}\right)$ \\
\hline 752344 & 9829779 & 0,93 & \\
\hline 752241 & 9828888 & 0,91 & \\
\hline 752778 & 9827924 & 0,79 & 0,01 \\
\hline 753293 & 9827532 & 0,80 & \\
\hline 753323 & 9827543 & 0,80 & \\
\hline 754355,6 & 9826759 & 0,80 & \\
\hline 755109 & 9825098 & 0,74 & 0,13 \\
\hline 756240 & 9824686 & 0,87 & 0,63 \\
\hline 757288 & 9823581 & 1,50 & \\
\hline 758616 & 9823103 & 0,88 & \\
\hline 759591 & 9822830 & 0,71 & \\
\hline 760864 & 9822498 & 0,68 & 0,06 \\
\hline 761684 & 9822258 & 0,79 & 0,05 \\
\hline 762462 & 9821910 & 0,88 & 0,04 \\
\hline 763075 & 9821747 & 0,95 & 0,02 \\
\hline 765950 & 9821444 & 0,98 & \\
\hline 767045 & 9819955 & 1,17 & \\
\hline 768037 & 9818819 & 1,18 & \\
\hline 768534 & 9818093 & 1,18 & 0,97 \\
\hline 769541 & 9817778 & 2,14 & \\
\hline \multicolumn{3}{|c|}{ Soma dos trechos } & 1,8 \\
\hline
\end{tabular}


Essas vazões foram comparadas com as estimativas de escoamento e infiltração descritas na seção 5.3 .

As vazões subterrâneas foram estimadas através da análise das extrações dos poços e nascentes localizadas em cada zona definida na BBRCH. Para a vazão subterrânea na zona 1 foi aplicada a Lei de Darcy como explicado na seção 5.3.

As estimativas de demanda e oferta por zonas e usos de recursos hídricos foram definidas com o intuito de comparar as zonas com déficit e com excedente de água na área de estudo.

\subsubsection{Problemas relevantes na gestão de recursos hídricos na $B B R C H$}

Foram analisados os possíveis problemas de caráter legal, administrativo, institucional, jurisdicional e antropogênico que poderiam ocorrer em cada zona devido à oferta e à demanda de água, além das diferentes outorgas. Esta análise foi realizada, considerando que cada zona é um território com características muito particulares, para as quais a proposta de gestão teria que ser individual.

Em cada zona foram identificadas as demandas de água nos diferentes setores. Tais estimativas foram contrastadas com os valores de oferta e de outorgas, levando-se em consideração os tipos de usos e os usuários de recursos hídricos. Ademais, em cada zona foram identificadas as maiores outorgas e as infraestruturas hidráulicas (aquedutos de irrigação/domésticos, hidrelétricas, indústria de cimento) que demandam maior ou menor quantidade de água. As outorgas foram localizadas, espacialmente, e analisadas em detalhe a partir dos arquivos da SENAGUA até o ano 2010 (informações de requerimento, nome do responsável, data de outorga).

No âmbito legal, administrativo, institucional e jurídico, foram analisados os problemas que podem afetar a governabilidade de recursos hídricos em cada zona, tais como: i) coordenação e fragmentação de tarefas entre instituições que gerenciam os recursos hídricos, bem como os papéis e responsabilidades pouco claros das mesmas; ii) definição geográfica entre limites hidrológicos, hidrogeológicos e administrativos; iii) falta de informação pública (Governo Nacional, Prefeituras, Universidades, EP-EMAPAR) sobre os recursos hídricos em termos de quantidade e qualidade ou, ao mesmo tempo, informações 
dispersas entre as diferentes instituições regionais e nacionais; iv) falta de assessoria legal e técnica sobre aquedutos para irrigação e para captações domésticas, principalmente nas áreas rurais; v) dificuldade na aplicação da política da água na criação de Comitês de Bacias, Juntas ou Diretórios de água com visão da gestão integrada de recursos hídricos; e vi) limitação econômica para geração de informação, criação de infraestrutura e até mesmo para fortalecimento social. 


\section{RESULTADOS}

\subsection{Hidrometeorologia}

Das 12 estações escolhidas para caracterizar o regime da precipitação na $\mathrm{BBRCH}, 10$ estão dentro da área de estudo e duas fora, mas fazem parte da bacia do rio Chambo. As estações foram classificadas e agrupadas de acordo com a quantidade de dados existentes e com os regimes pluviométricos (variação da precipitação ao longo de um ano), considerando os valores máximos e mínimos, sendo formados dois grupos (Figura 25).

As estações do grupo 1 (M0393, M0408, M0057, M1036, M0243, M0394, M0133, M0406) mostram uma precipitação distribuída de forma bimodal (2 picos máximos e 2 picos mínimos de precipitação) com picos de chuva nos meses de março até maio e de outubro até novembro. A precipitação média mensal para este grupo varia de 10 a $130 \mathrm{~mm} / \mathrm{mês}$. A estação M0406 registra os valores máximos, enquanto o M0408 registra os valores mínimos.

O grupo 2 (M0407, M0400 e M0390) é unimodal (1 pico máximo e 1 pico mínimo de precipitação) com chuvas nos meses de março até maio e um ligeiro aumento de chuvas em outubro. A precipitação média varia de 22 a 142 $\mathrm{mm} / \mathrm{mês}$. A estação M0407 tem os valores mais altos, enquanto a estação M0400 os menores valores.

A estação M0396 (Alao) localizada fora da BBRCH também foi analisada. O regime de precipitação é unimodal com um período chuvoso nos meses de junho e julho. Devido à localização geográfica desta estação, poderia se dizer que os valores de precipitação têm influência da Amazônia.

A distribuição espacial da precipitação usou a série de dados interanuais das estações descritas acima. Observa-se que as maiores precipitações (1100$1200 \mathrm{~mm}$ ) estão localizadas nos extremos nordeste e sudeste da BBRCH. Enquanto na porção central da BBRCH (vales de Guano e Riobamba) os valores das precipitações diminuem (500 - $600 \mathrm{~mm}$ ) (Figura 26). Donde se pode dizer que os valores de precipitação das estações do grupo 2 (localizadas ao nordeste e sudeste do rio Chambo) teriam influência da Amazônia. 

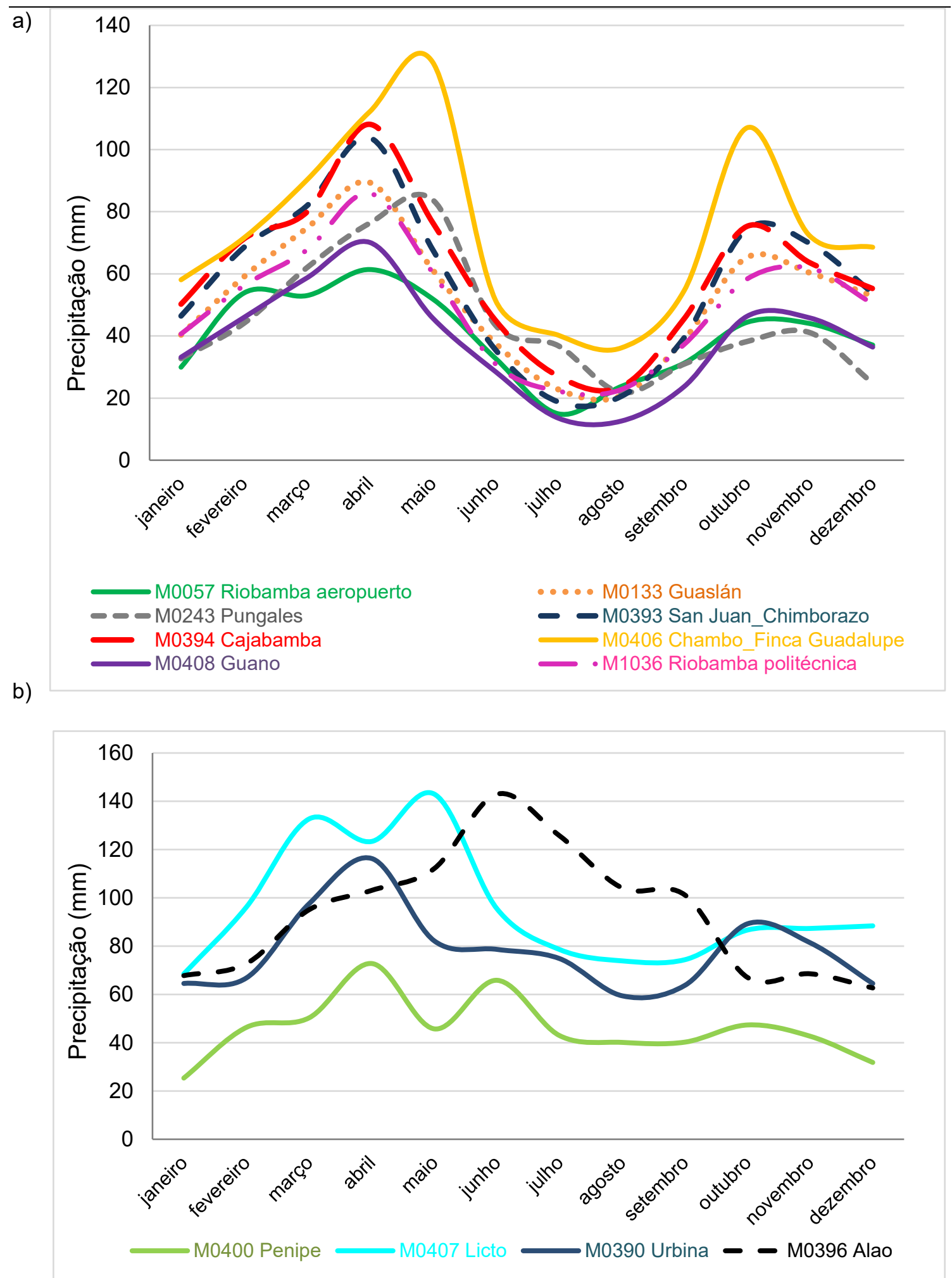

Figura 25. Variação da precipitação média mensal durante um ano: a) grupo 1(M0057, M0133, M0243, M0393, M0394, M0406, M0408, M1036) e b) grupo 2 (M0400, M0407, M0390 e M0396). 


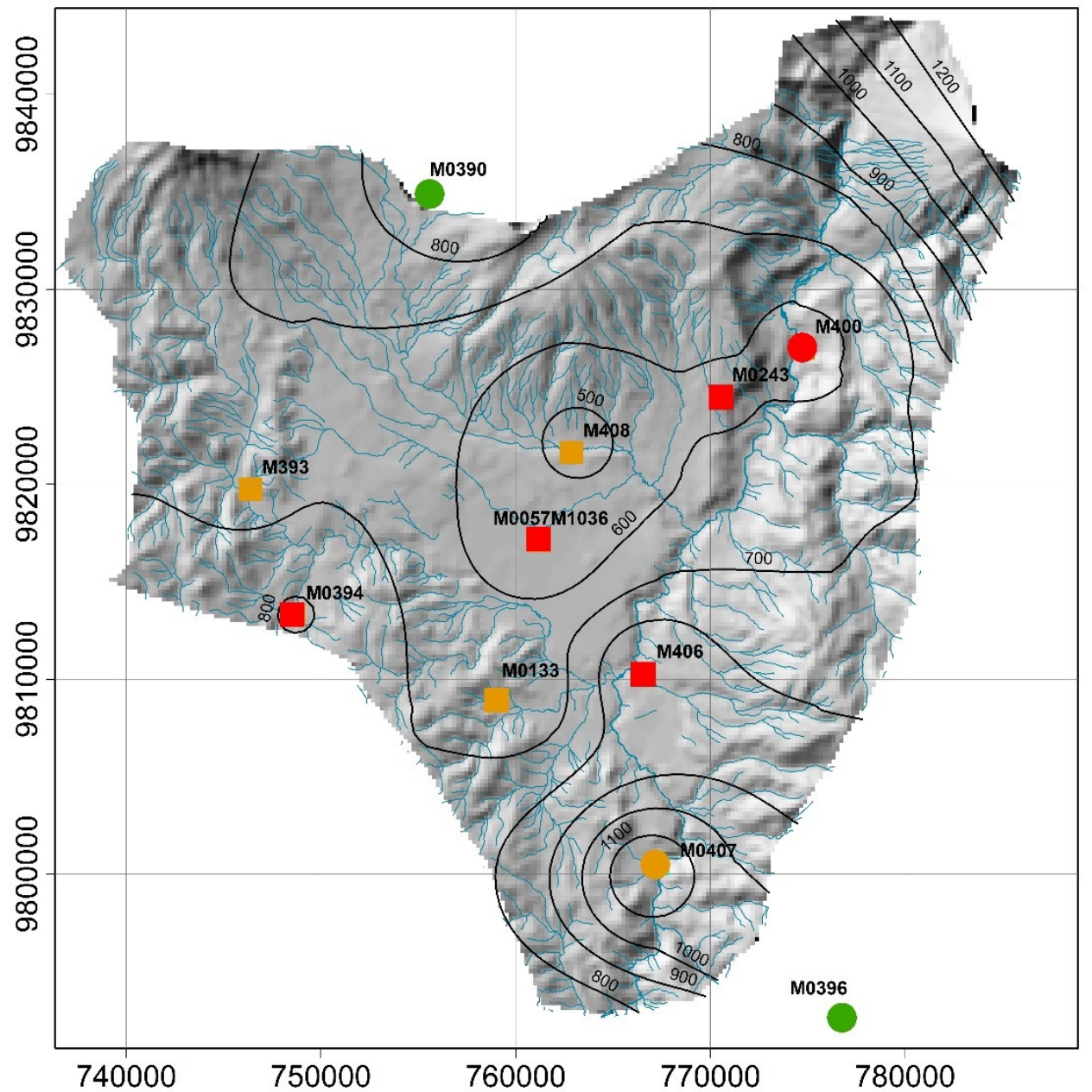

\begin{tabular}{|l|l|}
\hline \multicolumn{2}{|c|}{ LEGENDA } \\
500 Isoietas \\
Drenagem \\
Estações ativas \\
dentro da BBRCH \\
Estações fora da BBRCH \\
Estações \\
fora de operação \\
Grupo 1 & Grupo 2 \\
M0057 & M0400 \\
M0133 & M0407 \\
M0243 & Fora da BBRCH \\
M0393 & M0390 \\
M0394 & M0396 \\
M0406 & \\
M0408 & \\
M1036 & \\
\hline
\end{tabular}
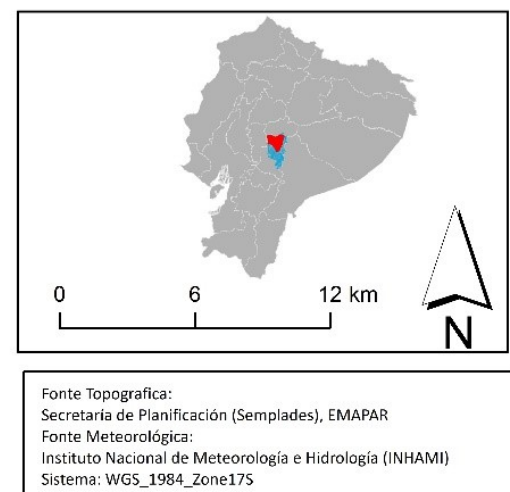

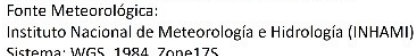

$740000 \quad 750000 \quad 760000 \quad 770000 \quad 780000$

Figura 26. Distribuição espacial da precipitação $(\mathrm{mm})$ com série de dados interanuais das estações climatológicas e pluviométricas ativas e fora de operação. 
$\mathrm{A}$ análise dos dados de temperatura na $\mathrm{BBRCH}$ considerou aspectos semelhantes aos analisados para a precipitação, ou seja, distribuição temporal e espacial. Foram analisados os dados de 4 estações (M0057, M0133, M0243, M1036) que pertencem ao grupo 1. Deve-se notar que essas estações são as únicas que possuem dados relativos a essa variável. Assim na $\mathrm{BBRCH}$ a temperatura média mensal não ultrapassa os $13^{\circ} \mathrm{C}$, as temperaturas mais baixas ocorrem entre julho e setembro $\left(12,5^{\circ} \mathrm{C}\right)$ e as maiores no mês de dezembro $\left(15,7^{\circ} \mathrm{C}\right)$ (Figura 27$)$.

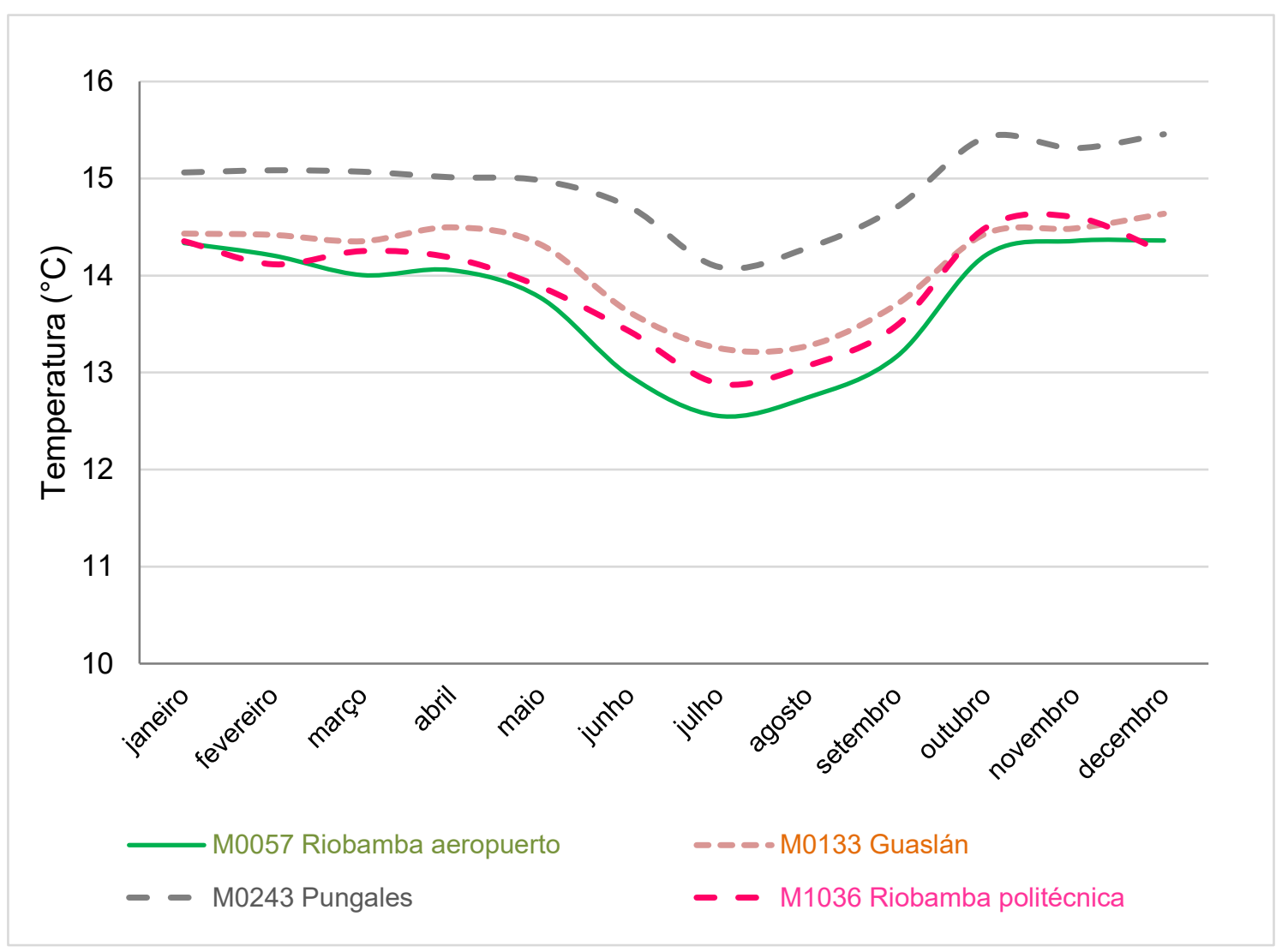

Figura 27. Distribuição mensal e temporal da temperatura da $B B R C H$. 


\subsection{Zoneamento do meio físico da BBRCH}

Das informações de morfologia (altitude, elevações, vulcões) e drenagens principais (considerados como limites das zonas), taxonomia (tipos de solos andinos com conteúdo de cinza vulcânica da granulometria da argila, siltito e areia), ocupação do solo (urbano ou rural), formações geológicas e hidrogeológicas, foram definidas 8 zonas, como descrito na Tabela 9 e mostrado na Figura 28.

Tabela 9. Zoneamento da área de estudo - 8 zonas definidas de acordo com as principais características geomorfológicas.

\begin{tabular}{|c|c|c|c|c|c|c|c|}
\hline Zona & Localização & $\begin{array}{l}\text { Área } \\
\mathrm{Km}^{2}\end{array}$ & $\begin{array}{l}\text { Altitude } \\
\text { m.s.n.m. }\end{array}$ & $\begin{array}{l}\text { Elevações } \\
\text { e vulcões }\end{array}$ & $\begin{array}{c}\text { Drenagem } \\
\text { principal }\end{array}$ & $\begin{array}{c}\text { Taxonomia } \\
\text { do solo }\end{array}$ & $\begin{array}{c}\text { Ocupação } \\
\text { do solo }\end{array}$ \\
\hline Z1 & $\begin{array}{c}\text { Noroeste: C. } \\
\text { Ocidental }\end{array}$ & 453 & $\begin{array}{l}5018 \\
2840\end{array}$ & $\begin{array}{c}\text { Chimborazo } \\
\text { Igualata }\end{array}$ & $\begin{array}{c}\text { Chimborazo, } \\
\text { Guano. }\end{array}$ & $\begin{array}{l}\text { Andisol } \\
\text { Mollisol } \\
\text { Entisol }\end{array}$ & Rural \\
\hline $\mathrm{Z2}$ & $\begin{array}{c}\text { Leste: C. } \\
\text { Oriental }\end{array}$ & 401 & $\begin{array}{l}5319 \\
2560\end{array}$ & $\begin{array}{c}\text { El Altar } \\
\text { Tungurahua }\end{array}$ & $\begin{array}{l}\text { Alao, Ishi, } \\
\text { Uldán, } \\
\text { Blanco, } \\
\text { Puela. }\end{array}$ & $\begin{array}{l}\text { Andisol } \\
\text { Mollisol } \\
\text { Entisol }\end{array}$ & Rural \\
\hline Z3 & Rio Chambo & 38 & $\begin{array}{l}3560 \\
2560\end{array}$ & & Chambo & Entisol & \\
\hline Z4 & $\begin{array}{c}\text { Central: } \\
\text { vales de } \\
\text { Riobamba e } \\
\text { Guano }\end{array}$ & 224 & $\begin{array}{l}3240 \\
2520\end{array}$ & & $\begin{array}{c}\text { Guano, } \\
\text { Cajabamba, } \\
\text { Chibunga }\end{array}$ & Entisol & Rural \\
\hline Z5 & $\begin{array}{l}\text { Centro- } \\
\text { Oeste }\end{array}$ & 90 & $\begin{array}{l}3120 \\
4240\end{array}$ & & $\begin{array}{l}\text { Chimborazo, } \\
\text { Cajabamba }\end{array}$ & $\begin{array}{l}\text { Andisol } \\
\text { Mollisol }\end{array}$ & Rural \\
\hline Z6 & Riobamba & 16 & $\begin{array}{l}2760 \\
2840\end{array}$ & & Chibunga & & Urbano \\
\hline $\mathrm{Z7}$ & Guano & 1 & $\begin{array}{l}2680 \\
2720\end{array}$ & & Guano & & Urbano \\
\hline Z8 & Sudoeste & 235 & $\begin{array}{l}3680 \\
2880\end{array}$ & & $\begin{array}{c}\text { Cajabamba, } \\
\text { Chibunga, } \\
\text { Chambo }\end{array}$ & $\begin{array}{l}\text { Mollisol } \\
\text { Entisol }\end{array}$ & Rural \\
\hline
\end{tabular}




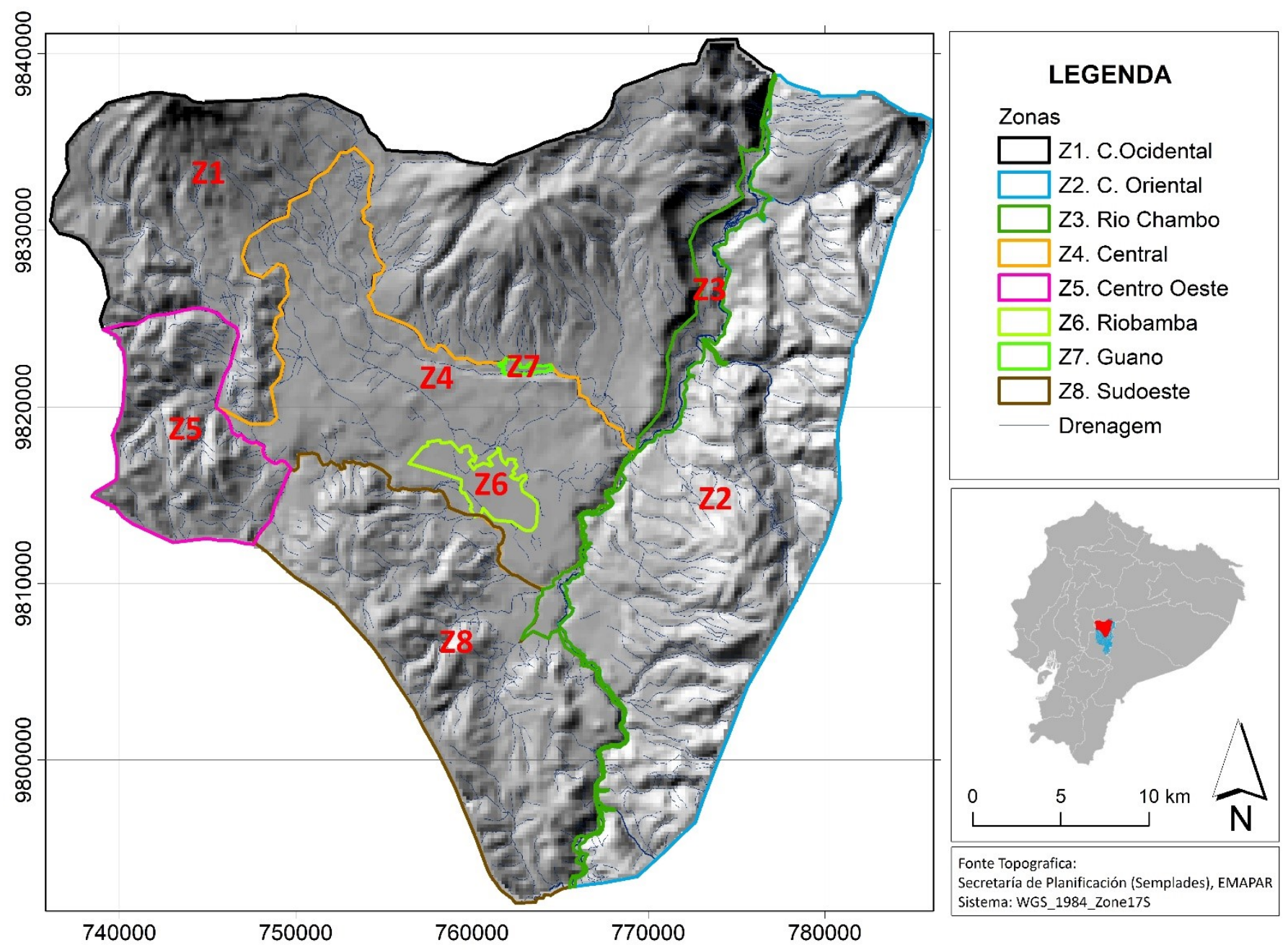

Figura 28. Zoneamento da área de estudo mostrando as 8 zonas delimitadas a partir da morfologia, taxonomia (tipos de solos andinos) e ocupação do solo (urbano e rural). 


\subsection{Recarga determinada por balanço hídrico}

O cálculo da recarga local baseou-se nas 8 zonas definidas anteriormente. A zona 1, correspondente ao Chimborazo e Igualata, não contou com dados de estações para análise, no entanto a recarga nesta zona foi calculada através dos dados potenciométricos e a aplicação da Lei de Darcy, como descrito na seção 5.3 e mostrado na Tabela 10. Os resultados mostraram que a recarga lateral devida ao Chimborazo é maior $\left(1,91 \mathrm{~m}^{3} / \mathrm{s}\right)$ que a estimada para o Igualata $(1,54$ $\left.\mathrm{m}^{3} / \mathrm{s}\right)$

Tabela 10. Aplicação da Lei de Darcy para estimativa da recarga lateral devida ao Chimborazo e Igualata.

\begin{tabular}{|c|c|c|c|c|c|c|}
\hline Poços & $\begin{array}{c}\mathrm{K} \\
(\mathrm{m} / \mathrm{s})\end{array}$ & $\begin{array}{l}\Delta \mathrm{H} \\
(\mathrm{m})\end{array}$ & $\begin{array}{l}\Delta \mathrm{L} \\
(\mathrm{m})\end{array}$ & $\begin{array}{c}\text { Espessura } \\
\text { Formação } \\
\text { (m) }\end{array}$ & $\begin{array}{l}\text { Área } \\
\left(\mathrm{m}^{2}\right)\end{array}$ & $\begin{array}{c}Q \\
\left(\mathrm{~m}^{3} / \mathrm{s}\right)\end{array}$ \\
\hline Llío\#5 & 6,04E-06 & 900 & 10197 & 200 & $3,9 \mathrm{E}+06$ & 2,11 \\
\hline Brigada & $1,05 E-05$ & 1216 & 23381 & 150 & $2,9 E+06$ & 1,51 \\
\hline $\begin{array}{l}\text { San Martín de } \\
\text { Veranillo }\end{array}$ & 2,13E-05 & 1220 & 23497 & 90 & $1,79 \mathrm{E}+06$ & 1,98 \\
\hline Média & & & & & & 1,91 \\
\hline Llío\#5 & 6,04E-06 & 600 & 5458 & 100 & $2,2 \mathrm{E}+06$ & 1,46 \\
\hline Pinicucho bajo & $6,04 \mathrm{E}-06$ & 1560 & 10085 & 100 & $1,73 E+06$ & 1,61 \\
\hline Média & & & & & & 1,54 \\
\hline
\end{tabular}

A recarga local determinada por balanço hídrico contemplou a estimativa do volume de água que infiltra e escorrega em cada uma das zonas por um determinado tempo. Para isso, dividiram-se as zonas em duas classes, uma correspondente às zonas com maior conteúdo de areia $(50 \%$ de areia, alta permeabilidade ou baixo escoamento) e outra às zonas com argila (50\% de argila, baixa permeabilidade ou alto escoamento). Assim também no mapa de uso e ocupação do solo, que inicialmente classificou a área de estudo em duas zonas: agrícolas e urbanas, foram descritos blocos (de 0 até 6), de acordo com 
o tipo de ocupação do solo e a sua capacidade de escoamento, resultando em zonas, blocos e classes (Tabela 11).

Tabela 11. Capacidade de permeabilidade do solo considerando tipo de solo, uso e ocupação de solo e a declividade nas zonas estabelecidas neste estudo.

\begin{tabular}{|c|c|c|c|c|c|}
\hline Zona & Nome & $\begin{array}{c}\text { Declividade } \\
\%\end{array}$ & Bloco & Classe & Solo \\
\hline 1 & $\begin{array}{c}\text { Chimborazo e } \\
\text { Igualata }\end{array}$ & $>7$ & Bloco 0 & 1 & Areia \\
\hline 2 & $\begin{array}{l}\text { Cordilheira } \\
\text { Real }\end{array}$ & $>7$ & $\begin{array}{l}\text { Bloco } 5 \\
\text { Bloco } 6\end{array}$ & 1 & $\begin{array}{l}\text { Argila } \\
\text { Areia }\end{array}$ \\
\hline 3 & Descarga & $>7$ & Bloco 5 & 1 & Argila \\
\hline 4 & $\begin{array}{c}\text { Central } \\
\text { (Formação } \\
\text { Riobamba) }\end{array}$ & $\begin{array}{l}<2 \\
<2 \\
2-7 \\
2-7\end{array}$ & $\begin{array}{l}\text { Bloco } 1 \\
\text { Bloco } 2 \\
\text { Bloco } 3 \\
\text { Bloco } 4\end{array}$ & 1 & $\begin{array}{l}\text { Argila } \\
\text { Areia } \\
\text { Argila } \\
\text { Areia }\end{array}$ \\
\hline 5 & Centro-Oeste & $\begin{array}{l}2-7 \\
>7\end{array}$ & $\begin{array}{l}\text { Bloco } 3 \\
\text { Bloco } 5\end{array}$ & 1 & $\begin{array}{l}\text { Argila } \\
\text { Argila }\end{array}$ \\
\hline 6 & Riobamba & $<2$ & Bloco 2 & 2 & Areia \\
\hline 7 & Guano & $<2$ & Bloco 2 & 2 & Areia \\
\hline 8 & Sudoeste & $>7$ & Bloco 6 & 1 & Areia \\
\hline
\end{tabular}

Adicionalmente, em cada zona, foram avaliadas também as áreas com respeito à declividade, usando os critérios assinalados na seção 5.4 , pois esse parâmetro é diretamente proporcional à velocidade de escoamento superficial e inversamente proporcional à infiltração da água.

Posteriormente, em cada zona, bloco, e classe, estimaram-se os valores de precipitação, recarga, evapotranspiração e escoamento superficial (Tabela 10). Os resultados mostraram que para as zonas 3 até 8 os valores do escoamento superficial e da recarga são baixos (Tabela 12). Ou seja, a recarga devido à chuva na $\mathrm{BBRCH}$ é baixa $(8,88 \%$ até $0,6 \%$ da precipitação), exceto na zona 2 que apresenta a maior recarga (22,33 \% da precipitação). 
Tabela 12. Valores em mm/ano observados para a precipitação, recarga, evapotranspiração e escoamento superficial na BBRCH.

\begin{tabular}{lccccccc}
\hline Zonas/Parâmetros & $\mathbf{2}$ & $\mathbf{3}$ & $\mathbf{4}$ & $\mathbf{5}$ & $\mathbf{6}$ & $\mathbf{7}$ & $\mathbf{8}$ \\
\hline $\begin{array}{l}\text { Precipitação } \\
\text { (mm/ano) }\end{array}$ & 1020 & 766 & 676 & 719 & 540 & 460 & 732 \\
$\begin{array}{l}\text { Recarga } \\
\text { (mm/ano) }\end{array}$ & 227 & 68 & 35 & 47 & 4 & 2 & 61 \\
$\begin{array}{l}\text { Evapotranspiração } \\
\text { (mm/ano) }\end{array}$ & 649 & 605 & 548 & 580 & 455 & 389 & 576 \\
$\begin{array}{l}\text { Escoamento } \\
\text { (mm/ano) }\end{array}$ & 170 & 130 & 115 & 131 & 79 & 68 & 125 \\
\hline
\end{tabular}

\subsection{Geologia}

\subsubsection{Geologia Regional}

O Equador situa-se em uma região tectônica e vulcanicamente ativa devido à convergência da Placa de Nazca e da Placa Sul-Americana desde o Oligoceno (Gutscher, Malavieille, Lallemand, \& Collot, 1999). Segundo Aspden \& Litherland (1992) as cadeias montanhosas da Cordilheira Ocidental e Oriental são formadas por rochas de natureza alóctones e autóctones, incorporadas ao continente durante vários períodos geológicos (Figura 29).

A Cordilheira Oriental é composta basicamente por rochas metamórficas agrupadas em divisões tectônicas distribuídas de oeste a leste pelas unidades (paleozoicas e mesozoicas): Guamote, Alao, Loja, Salado e Zamora. Essas divisões estão separadas por fraturas regionais conhecidas como Peltetec, Frente Baños, Llanganates e Cosanga Mendez. Sobrepostos às rochas metamórficas encontram-se depósitos vulcânicos cenozoicos (Litherland, Aspend, \& Jemielita, 1994) (Figura 29).

A cordilheira ocidental é formada por duas divisões tectônicas chamadas Pallatanga e Macuchi. A primeira divisão constitui o embasamento é formado pelas rochas de origem oceânica (turbiditos, basaltos e sedimentos marinhos profundos), que foram acumuladas no continente durante o Cretáceo-Eoceno através da fratura Calacalí-Pallatanga-Pujilí (Hughes \& Pilatasig, 2002). A 
segunda divisão é constituída por uma sequência vulcanossedimentar (arenitos e brechas vulcânicas de composição basáltica a andesítica) que foi agregado contra a unidade de Pallatanga ao longo da zona de cisalhamento de Chimbo Toachi no final do Eoceno (Hughes \& Pilatasig, 2002)(Figura 29).

O Vale Interandino é limitado por falhas associadas à origem da Cordilheira dos Andes. Estende-se desde o Vale de Chota ao norte até Alausí ao sul. De acordo com Winkler, et al., (2005), o vale começou a se formar no final do Mioceno. O embasamento corresponde às rochas oceânicas pertencentes ao terreno de Pallatanga (Villagómez, 2003) e os materiais que o preenchem são essencialmente depósitos vulcânicos e sedimentos vulcânicos da era plioquaternária (Litherland, Aspend, \& Jemielita, 1994).

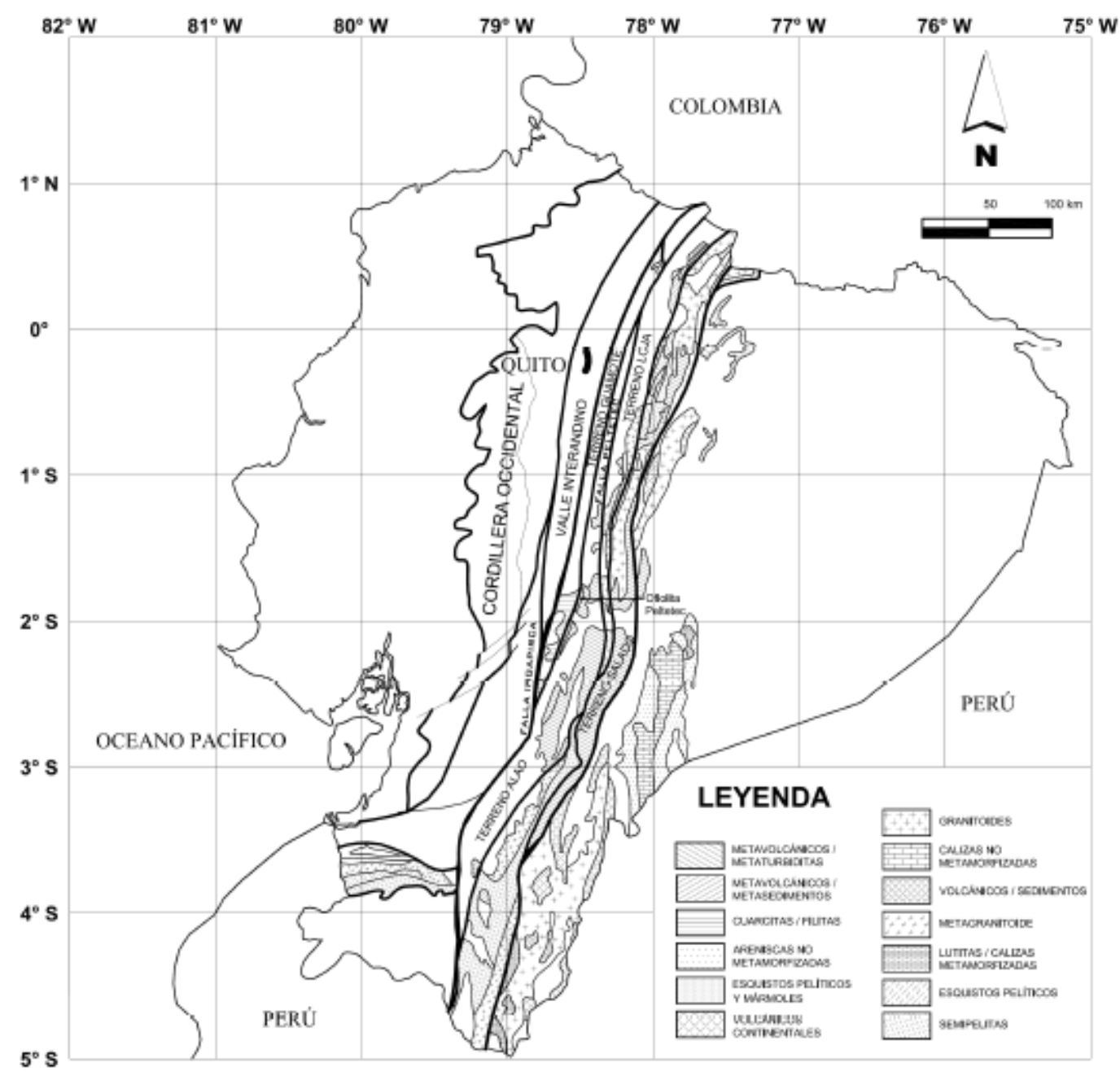

Figura 29. Principais estruturas e terrenos alóctones e autóctones que formam a Cordilheira Ocidental, Oriental e o Vale Interandino. Fonte: Reyes (2008). 


\subsubsection{Vulcanismo Equatoriano}

O vulcanismo do Equador mostra-se registrado na Cordilheira dos Andes desde o Mioceno-Plioceno. No centro do país está representado pelas formações Pisayambo, Sicalpa, Cisarán, Tarqui e Quimsacocha (Beate et al., 2001). Os produtos vulcânicos do Plio-Pleistoceno estão localizados nas regiões mais antigas dos vulcões mais velhos e são denominados como vulcânicos indiferenciados (BGS-CODIGEM, 1997).

O arco vulcânico do Quaternário está representado por 84 vulcões distribuídos na Cordilheira Ocidental (frente vulcânica: Chimborazo, Carihuairazo, entre outros), Vale Interandino e Cordilheira Oriental (arco vulcânico principal: Igualata, Calpi, Tulabug etc e Altar, Tungurahua etc.) e levantamento subandino (Sumaco, Pan de Azúcar, Yanayacu etc.) (Hall \& Beate, 1991) (Figura 30).

O vulcanismo quaternário está caracterizado por uma complexa alternância de lavas básicas e intermediárias (dacito anfibolítico e andesitos com piroxênios) na Cordilheira Ocidental; lavas básicas até ácidas (basaltos até riolitos) no Vale Interandino; lavas de andesitos ácidos e básicos, produtos piroclásticos, lavas riolíticas na Cordilheira Oriental; e rochas alcalinas no levantamento subandino (Hall \& Beate, 1991); (Barberi, et al., 1988). Há também registros de atividade vulcânica desde o Holoceno (potencialmente ativos, 17 vulcões), histórica (ativos; 5) e atual (3: Cotopaxi, Tungurahua, Pichincha) (Bernard \& Andrade, 2011) (Figura 30). 


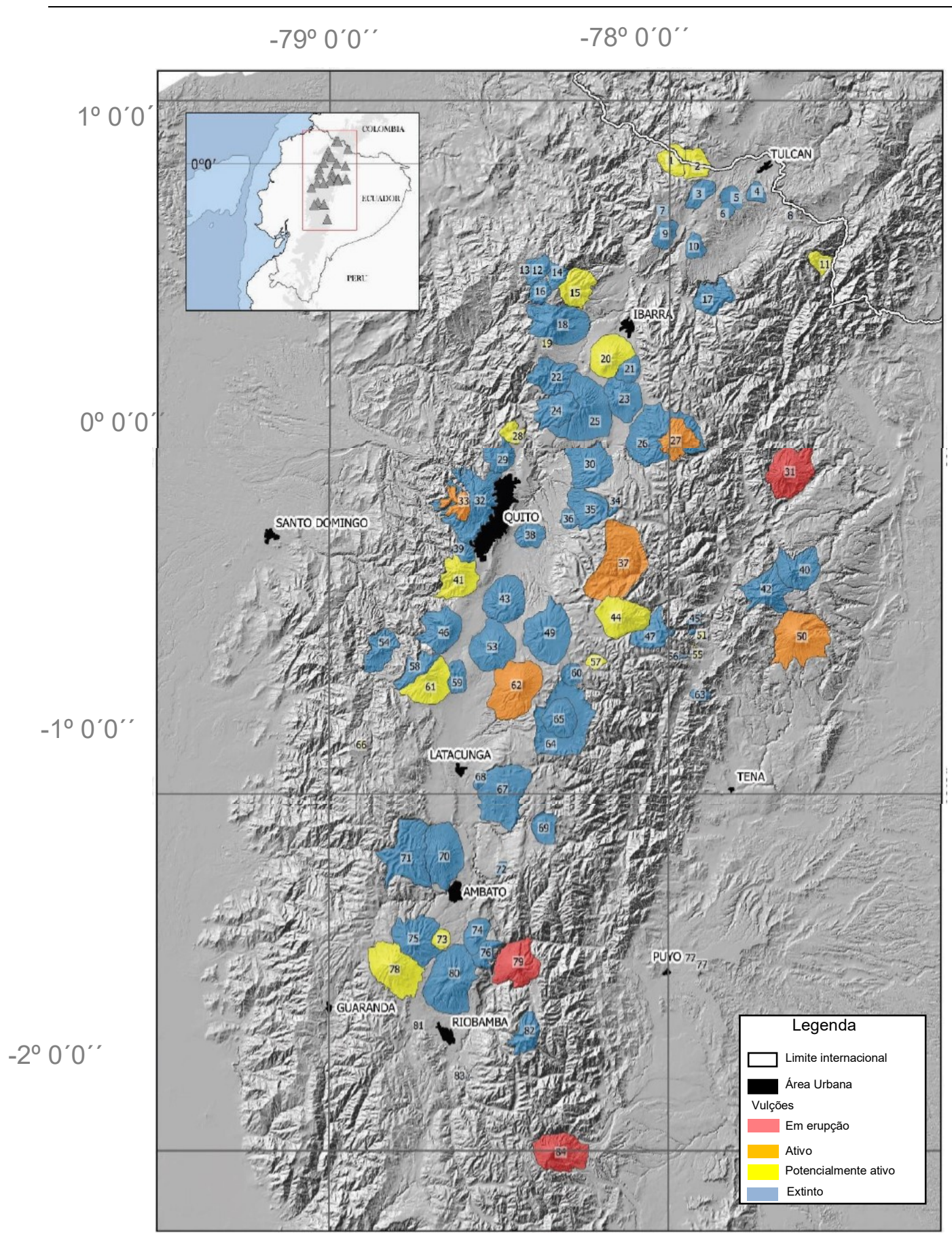

Figura 30. Divisão do arco vulcânico Plio-Quaternário do Equador. Evidencia-se três lineamentos de oeste para leste: frente vulcânica, arco principal e levantamento subandino, segundo o ponto de vista da atividade vulcânica (Modificado de Bernard e Andrade, 2011). 


\subsubsection{Geologia Local}

A área de estudo situa-se na bacia vulcanossedimentar do rio Chambo, na depressão interandina, onde sequências sedimentares, vulcanossedimentares pliocênicas e pleistocênicas recobrem o embasamento mesozoico, constituído na região pelas rochas jurássicas da Unidade Alao Paute, Guamote, rio Daldal, San Pablo de Sali e as rochas cretáceas da Unidade Peltetec e Formação Yunguilla. As unidades que constituem o embasamento da $\mathrm{BBRCH}$ estão localizadas na zona 2, na Cordilheira Oriental (Figura 31), e são descritas a seguir:

a) Unidade Alao-Paute: localiza-se na margem norte do rio Uldán (Figura 31). A unidade é composta pelas rochas de origem vulcânica com metamorfismo de baixo grau. As rochas predominantes são xistos verdes e metabasaltos. Os xistos verdes têm foliação intensa (NNE coincidentes com estruturas regionais) e dobras variáveis, textura grossa, com mais de $50 \%$ de clorita, além de lentes de quartzo (Anexo I);

b) Unidade San Pablo de Sali: localiza-se na margem leste do rio Blanco (Figura 31). Está constituída por metaconglomerados, quartzitos brancos e cinzas com veios de quartzo, filitos deformados negros e ardósias negras de aporte principalmente continental (Reyes, 2006). As rochas formam faixas subparalelas separadas por rochas metamórficas da Unidade Peltetec, principalmente. Análises microscópicas realizadas por Yánez (2016) descrevem a composição mineralógica desta unidade que é constituída por cristais de quartzo (80\%), feldspato (15\%), biotita (1\%), muscovita (1\%) e líticos de chert deformados $(3 \%)$, além de sulfetos disseminados;

e) Unidade Peltetec: localiza-se no setor de Quimiag ao longo da Cordilheira Oriental e nas margens do rio Uldán (Figura 31) e forma um cinturão de fraturas alargadas com rochas como serpentinitas, gabros, basaltos serpentinizados, rochas verdes. As rochas evidenciam fraturas, alto grau de intemperismo e oxidação. Segundo Reyes (2006), as rochas desta unidade estariam relacionadas com uma sequência de crosta oceânica (ofiolito) sem unidade basal, com sequência de cumulados máficos (gabros), seguidos de uma sucessão de sedimentos marinos profundos, ricos em ferro e manganês e sem unidade de sheeted dikes; 
f) vulcânicos El Altar: localizam-se na margem esquerda do rio Blanco e direita do rio Chambo, nas zonas 1 e 3 (Figura 31). Os afloramentos são escassos devido a uma forte erosão glacial (Bustillos, 2008). Os vulcânicos estão constituídos por um depósito de avalanche de detritos formados por blocos de composição, essencialmente, andesítica de cores escuras (cinza, azul e negro) e espessura de $\sim 50 \mathrm{~m}$.

g) vulcânicos DAD Tungurahua ( 30Ka AP): localizados a nordeste da $\mathrm{BBRCH}$, na margem leste do rio Chambo (zona 3). Consistem em depósitos de avalanche de detritos que formam terraços aluviais de até $400 \mathrm{~m}$ de espessura e são compostos por clastos, essencialmente, andesíticos de tamanho variável (centímetros até metros). Os clastos estão deformados e fraturados, sendo parte da matriz areno-siltosa de cor cinza avermelhada. Segundo Salguero (2017) as rochas da avalanche contêm $15 \%$ de plagioclásio, $10 \%$ de hornblenda, $7 \%$ de clinopiroxênio, $5 \%$ de ortopiroxênio e $2 \%$ de óxidos e minerais opacos;

h) vulcânicos DAD Tungurahua ( $3 \mathrm{Ka} A P)$ : localizados no nordeste da $\mathrm{BBRCH}$, na margem leste do rio Chambo, nas proximidades do povoado de Puebla (zona 3) (Figura 28). Esses depósitos de avalanche são caracterizados por formar terraços de até, aproximadamente, $200 \mathrm{~m}$ de espessura e são depósitos de material grosso com blocos andesíticos (cinza, negro) de tamanho variável, em uma matriz areno-siltosa, com fragmentos de madeira carbonizada, que permitiu a sua datação (Bustillos, 2008). Em alguns clastos (cinza esverdeados) evidencia-se alteração hidrotermal (alteração de minerais máficos);

i) vulcânicos Igualata: localizam-se na zona 1 e 4 da BBRCH. Estão divididos em: fluxos de lava, depósitos de caída e piroclásticos e depósito de avalanche de detritos. Os fluxos de lava localizam-se a oeste do rio Chambo (Figura 31 e Figura 32). Litologicamente, são compostos por andesitos escuros (negros, azuis) com alto grau de faturamento. Os depósitos vulcanoclásticos de caída e fluxos piroclásticos cobrem essencialmente os vales de Guano e Riobamba e são compostos por estratos de areia vulcânica, cinza vulcânica fina e cinza compactada de cores claras (bege e marrom) com 60 m de espessura. Mineralogicamente, contêm $12 \%$ de plagioclásio, $5 \%$ de hornblenda, $3 \%$ de piroxênio e $70 \%$ de matriz com cristais de plagioclásio e vidro vulcânico (Salguero, 2017). Os fluxos piroclásticos correspondem a camadas basais de 
areias vulcânicas estratificadas, seguido por uma unidade de ignimbrito com clastos líticos andesíticos. O lahar é caracterizado por uma matriz-suportada com grandes clastos e blocos de até $1 \mathrm{~m}$ de composição andesítica.

j) vulcânicos Chimborazo: localizam-se nas zonas 1 e 4. Estão divididos em avalanche de detritos, depósitos de caída e piroclásticos e fluxos de lava. A avalanche de detritos tem espessura variável, dependendo da sua localização, podendo atingir os cerca de $200 \mathrm{~m}$ em Guano e os $10 \mathrm{~m}$ na zona 5 (Calpi) (Figura 31 e Figura 32). A avalanche tem granulometria grossa e está pobremente selecionada e sem estratificação. Está caracterizada pela abundância de clastos fraturados, variando de tamanho desde centímetros até metros $(25 \mathrm{~cm}$ até $3 \mathrm{~m})$. Os clastos são monolitológicos (andesito) e estão separados por uma matriz heterogênea da mesma composição. Os fluxos de lava ocorrem nas localidades de San Pablo e San Andrés, principalmente, e estão constituídos por andesitos escuros (cinza e azul) com cristais de plagioclásio e piroxênio (Figura 31);

k) Formação Cizarán: localiza-se na porção sudoeste da $\mathrm{BBRCH}$, nas zonas 4, 5 e). Está composta de produtos vulcânicos (sedimentos vulcanoclásticos grossos e lavas intermediárias). Os sedimentos vulcânicos estão representados por areias médias e grossas de cores claras (bege e marrom) e as lavas intermediárias de composição andesítica, com blocos (cinza, negros) de tamanho variável em uma matriz de areia média a grossa;

I) Formação Riobamba: localiza-se na zona 4 e numa porção noroeste da zona 8 (setor de Yaruquíes). A formação pode ser dividida em duas sequências, uma sedimentar e outra vulcanoclástica. A primeira está composta por uma sucessão de estratos sedimentares que, da base ao topo, está constituída por conglomerados monolíticos (andesito) em uma matriz areno-siltosa, seguida de camadas de arenito e siltito e arenitos finos dispostos horizontalmente. A sequência torna-se mais grossa à medida que se aproxima dos povoados de Cubijies e Quimiag. A sequência vulcanoclástica consiste em camadas de arenitos vulcânicos negros e bege, intercalados com pedra-pomes, líticos andesíticos e cinza vulcânica fina (Anexo I);

m) Formação Cangahua: localiza-se nas zonas 2, 3, 4 e 8. Litologicamente, são cinzas vulcânicas compactadas, maciças de cor marrom claro, bege, intercaladas por camadas de cinza branca e fina. A Cangahua constitui um 
material piroclástico retrabalhado que está distribuído por toda a região interandina (Clapperton \& Vera, 1886);

n) sedimentos da bacia Riobamba: localiza-se na zona 4, nas localidades de Cubijíes e Quimiag (Figura 31).

São sequências de arenitos finos e siltitos (marrom claro, bege) dispostos horizontalmente com uma estratificação planar e continua. O siltito localiza-se no topo da sequência;

o) coluviões: localizam-se na zona 1, acima dos 3600m de altitude (no Igualata e Chimborazo). Segundo Salguero (2017), correspondem a depósitos com líticos andesíticos. As coluviões localizam-se ao longo da zona 2, na margem do rio Blanco, Ulpán, principalmente. São compostos pela acumulação de líticos, essencialmente, andesíticos.

\subsubsection{Geologia Estrutural}

A área de estudo apresenta estruturas regionais com dinâmica e deformação complexas. O principal sistema de falhas Pallatanga (denominado assim por Winter, Avouac, \& Lavenu (1993), que é composto por diversos segmentos estruturais, se abre a partir do litoral (golfo de Guayaquil) e atravessa a Cordilheira Ocidental e o Vale Interandino (Hughes \& Pilatasig, 2002); (Alvarado, et al., 2016); (Salguero, 2017). Os traços morfológicos dessa estrutura são difíceis de evidenciar, uma vez que há bacias vulcanossedimentares que possuem grande espessura. No entanto, Alvarado (2016) e Salguero (2017) admitem a continuidade deste sistema de falhas na área de estudo.

Vários lineamentos e estruturas foram constatadas na área de estudo. No rio Guano foi possível observar uma orientação da rede de drenagem E-O. Salguero (2017) por meio da análise fotogeológica sugere que essa orientação topográfica pode constituir um lineamento denominado Guano-Altar. Esse lineamento coincide com o curso do depósito de avalanche do Chimborazo e nele observam-se nascentes e zonas úmidas localizadas na Formação Riobamba, nos setores de Cubijíes e Los Elenes (Figura 31). Da mesma forma, Salguero (2017) reporta outros lineamentos que atravessam as rochas vulcânicas na zona de estudo (lineamento Chibunga-Rio Ulpán, que atravessa os vulcânicos Calpi; o lineamento Calera-Urbina, que atravessa os vulcânicos 
Chimborazo e Igualata e o lineamento Alao, que atravessa os quaternários indiferenciados.

Yánez (2016) reporta estruturas no oeste e sudoeste das cidades de Riobamba e Guano. Rochas fraturadas, deformadas e zonas de cisalhamento foram mapeados na margem direita do rio Chambo e na borda ocidental da Cordilheira Real (Figura 31).

Em geral, o conhecimento dos trends dessas estruturas e de sua variação é importante, pois pode ter implicações na circulação da água, pelo que estudos estruturais detalhados são necessários na área de interesse. 


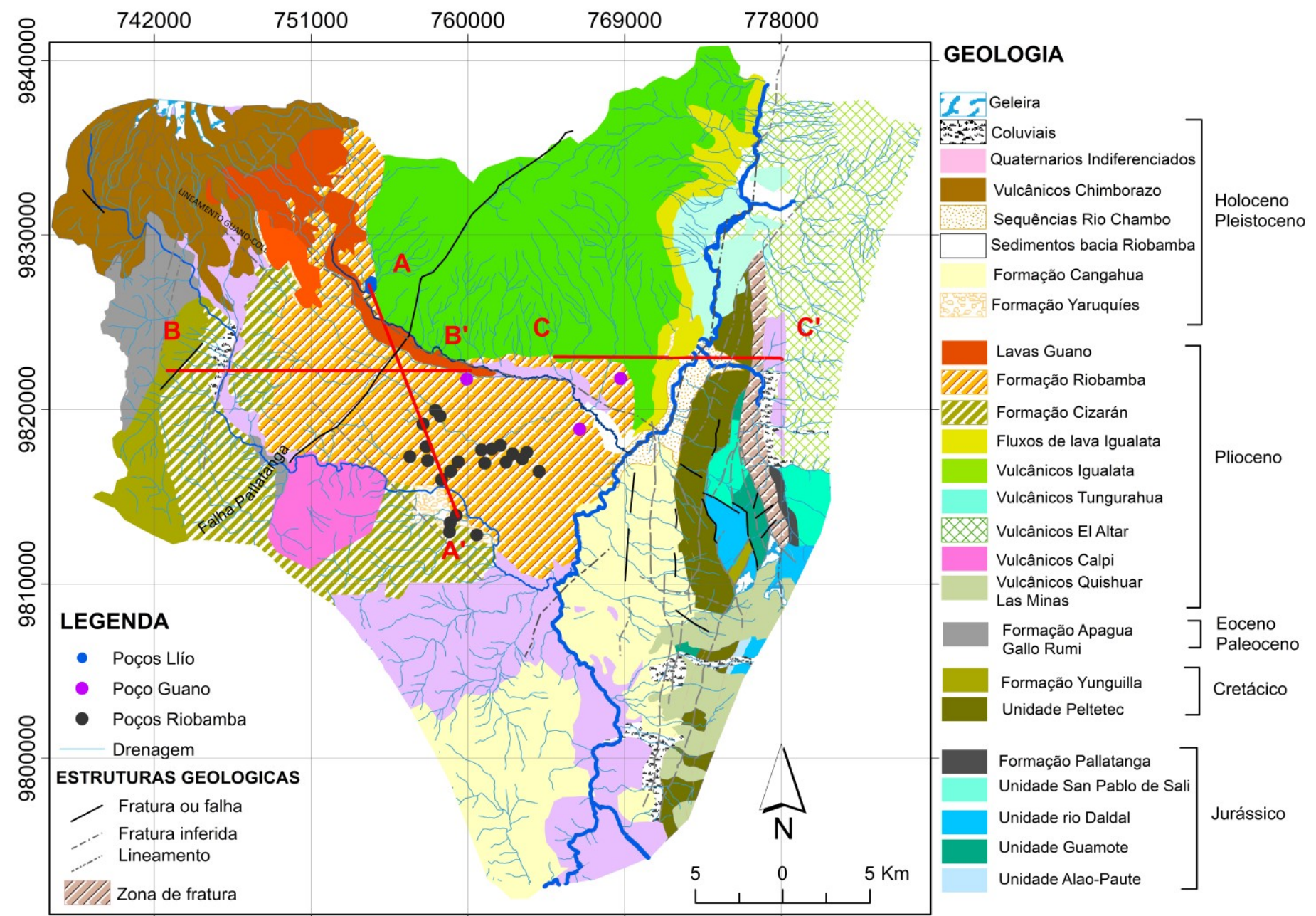

Figura 31. Geologia simplificada da área de estudo. Fonte: Modificado de Salguero, 2017; Yánez, 2016 ; Barba, 2008. 


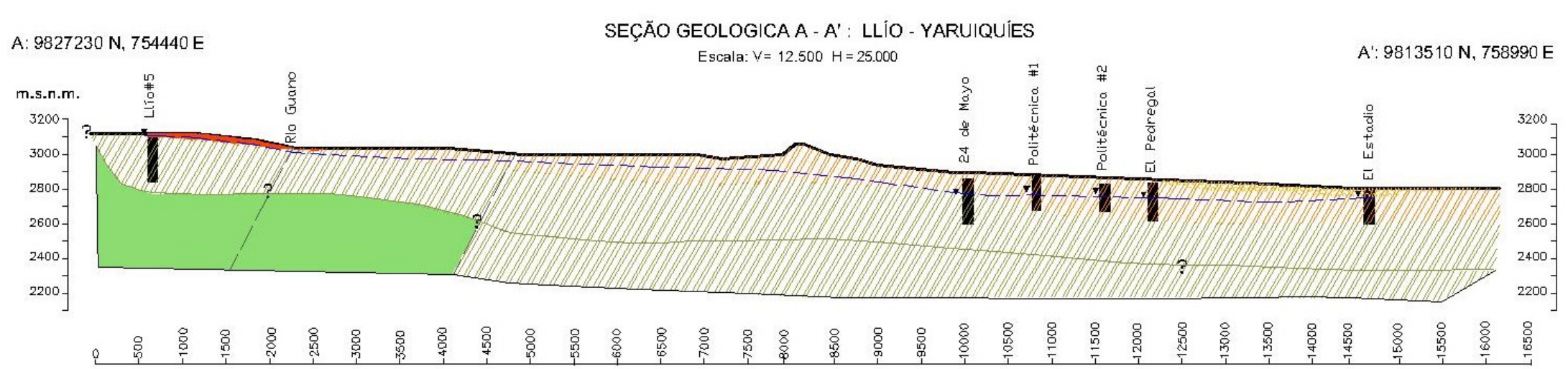

B: $9822000 \mathrm{~N}, 742716 \mathrm{E}$

SEÇÃO GEOLOGICA B - B' : SAN JUAN - RIO GUANO

Escala: $\vee=12.500 \quad H=25.000$

$B^{\prime}: 9822000 \mathrm{~N}, 760000 \mathrm{E}$
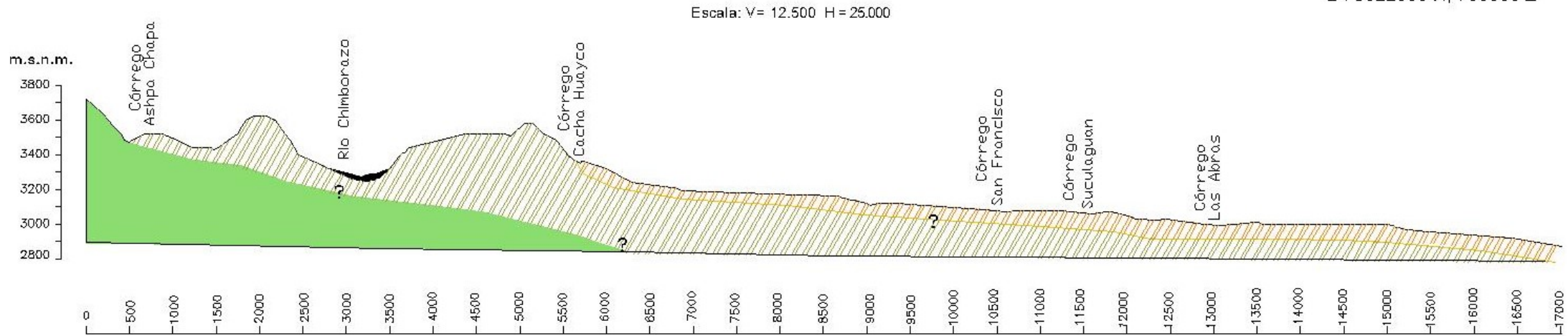

C: $9823000 \mathrm{~N}, 778000 \mathrm{E}$

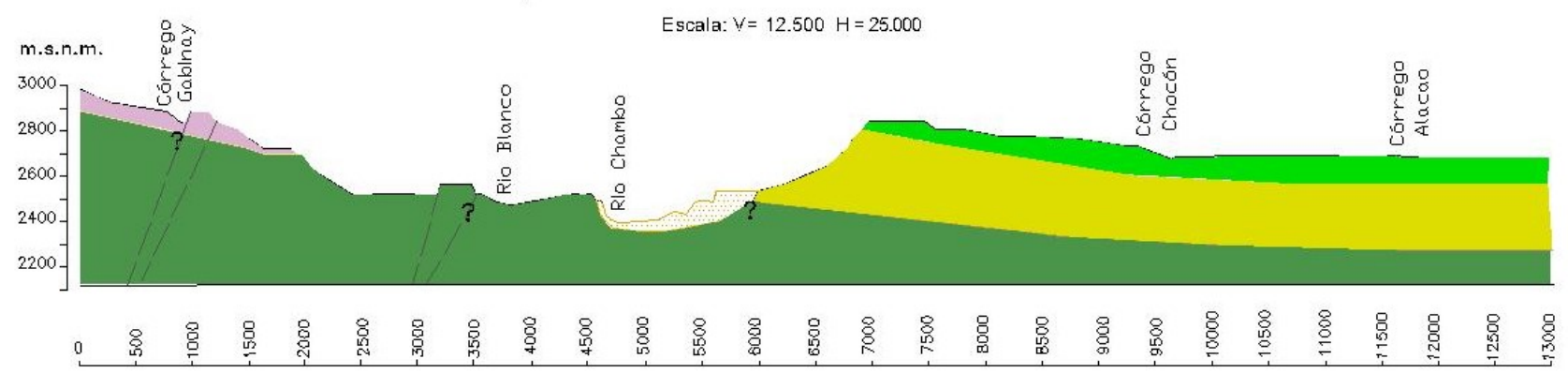

SIMBOLOGIA

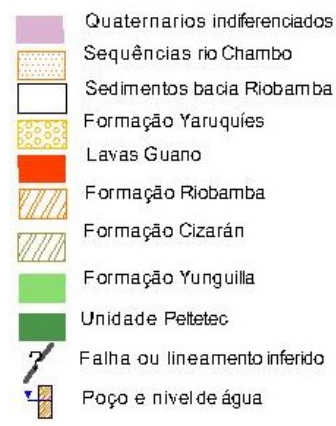

Figura 32. Seções geológicas e hidrogeológicas A-A', B-B' e C-C' na área de estudo. 


\subsection{Hidrogeologia}

Na área ocorrem três aquíferos, do tipo multicamadas, denominados LlíoGuano, Riobamba e Yaruquíes. O Aquífero Llío-Guano, localizado nas proximidades dos vulcões Chimborazo e Igualata, é do tipo livre, porosidade dupla, espessura média de $200 \mathrm{~m}$, associado aos depósitos vulcanogênicos das formações Chimborazo (superior) e Cizarán (inferior). A vazão média explotada é $0,27 \mathrm{~m}^{3} / \mathrm{s}$, dos quais $0,039 \mathrm{~m}^{3} / \mathrm{s}$ correspondem as vazões dos poços localizados em Llío e Guano (Tabela 13). O restante, $0,23 \mathrm{~m}^{3} / \mathrm{s}$, corresponde à nascente San Pablo, localizada aproximadamente $1 \mathrm{~km}$ ao sudoeste dos poços de Llío. Estes poços e a nascente constituem a fonte de água para abastecimento público da cidade de Riobamba e Guano.

A condutividade hidráulica é da ordem de $6,0 \times 10^{-6} \mathrm{~m} / \mathrm{s}$ e o nível de água médio igual a $65 \mathrm{~m}$, nos poços que atravessam os depósitos da Formação Chimborazo, e 140 m, naqueles perfurados na Formação Cizarán.

O Aquífero Riobamba situa-se nas regiões dos vales que ocorrem nas proximidades das cidades de Riobamba e Guano. Ele também é do tipo livre, porosidade primária, compostos pelos depósitos das formações Riobamba (superior) e Cizarán (inferior). A espessura média é de $150 \mathrm{~m}$, vazão igual a $0,012 \mathrm{~m}^{3} / \mathrm{s}$, condutividade hidráulica equivalente a $4,3 \times 10^{-5} \mathrm{~m} / \mathrm{s}$. Os valores médios de nível de água variam de acordo com a formação geológica explorada e encontram-se entre 90 m (Formação Riobamba) e 160 m (Formação Cizarán). Deve-se notar que só o poço 13 (24 de maio) explora a Formação Cizarán, tendo a maior vazão dos poços da cidade $\left(0,014 \mathrm{~m}^{3} / \mathrm{s}\right)$.

O Aquífero Yaruquíes é do tipo suspenso, extensão local, restrito às áreas próximas ao povoado homônimo. Sua espessura média é de $75 \mathrm{~m}$, vazão igual a $0,016 \mathrm{~m}^{3} / \mathrm{s}$ e condutividade hidráulica correspondente a $1,9 \times 10^{-7} \mathrm{~m} / \mathrm{s}$. Os valores médios de nível d'água variam entre 38 m (Formação Yaruquíes) e 110 m (Formação Riobamba).

As características hidrogeológicas dos aquíferos da região de Llío, Riobamba e Yaruquíes foram definidas através das interpretações dos testes de bombeamento de seis poços (um em Llío; quatro em Riobamba e um em Yaruquíes) realizados no momento da construção dos mesmos. Os testes em Llío e Riobamba foram realizados com duração de mais de 24 horas (Anexo III). 
Tabela 13. Parâmetros hidrogeológicos dos poços nos Aquíferos Guano (Llío-Guano, Riobamba e Yaruquíes).

\begin{tabular}{|c|c|c|c|c|c|}
\hline Cód. & Nome do poço & Aquífero & $\begin{array}{c}Q \\
\left(\mathrm{~m}^{3} / \mathrm{s}\right)\end{array}$ & $\begin{array}{c}K \\
(\mathrm{~m} / \mathrm{s})\end{array}$ & $\begin{array}{c}T \\
\left(\mathrm{~m}^{2} / \mathrm{s}\right)\end{array}$ \\
\hline 0 & Llío \#1 & & 0,055 & & \\
\hline 1 & Llío \#2 & & 0,062 & & \\
\hline 2 & Llío \#3 & & 0,014 & & \\
\hline 3 & Llío \#4 & & 0,046 & & \\
\hline 4 & Llío \#5 & Llío & 0,095 & $6,04 \mathrm{E}-06$ & 1,21E-03 \\
\hline 5 & Llío \#6 & & 0,046 & & \\
\hline 6 & Llío \#7 & & 0,027 & & \\
\hline 0 & Langos & Guano & 0,001 & 8,87E-07 & 1,53E-04 \\
\hline 1 & Chingazo alto & & 0,004 & $1,12 \mathrm{E}-05$ & 1,87E-03 \\
\hline 0 & San Gabriel & & 0,012 & & \\
\hline 1 & Espoch \#1 & & 0,011 & & \\
\hline 3 & Brigada Galápagos & Riobamba & 0,008 & $1,05 \mathrm{E}-05$ & $2,19 E-03$ \\
\hline 4 & Unach & & 0,015 & & \\
\hline 5 & Servidores & & 0,032 & & \\
\hline 6 & Las Abras & & 0,018 & & \\
\hline 7 & $\begin{array}{l}\text { San Martin de } \\
\text { Veranillo }\end{array}$ & & 0,007 & $2,13 \mathrm{E}-05$ & $3,42 \mathrm{E}-03$ \\
\hline 8 & Cumandá & & 0,006 & & \\
\hline 9 & Huerta & & 0,036 & & \\
\hline 10 & 21 de abril & & 0,012 & & \\
\hline 11 & María auxiliadora & & 0,004 & & \\
\hline 12 & 24 de mayo & & 0,014 & & \\
\hline 14 & El Carmen II & & 0,005 & $3,16 \mathrm{E}-04$ & 7,01E-02 \\
\hline 15 & Lican & & 0,003 & $2,05 \mathrm{E}-07$ & 4,07E-05 \\
\hline 16 & Liribamba & & 0,007 & 2,06E-05 & 4,78E-03 \\
\hline 17 & San Antonio & & 0,006 & 5,95E-06 & $9,25 E-04$ \\
\hline 20 & El Estadio & Yaruquíes & 0,030 & 1,94E-07 & 4,26E-05 \\
\hline 21 & Shuyo & & 0,001 & 1,94E-07 & 4,93E-05 \\
\hline 22 & El Pedregal & & 0,008 & & \\
\hline
\end{tabular}

Os aquíferos descritos apresentam vazões muito diferentes, posto que dependem da necessidade. As melhores vazões estão localizadas em Llío e San Pablo, setor onde passa o sistema de falhas Pallatanga. Esses poços e nascentes têm produtividade alta (valor médio de $0,27 \mathrm{~m}^{3} / \mathrm{s}$ ) enquanto isso em Riobamba e Yaruquíes a produtividade dos poços e nascentes é média $(0,012$ e $0,055 \mathrm{~m}^{3} / \mathrm{s}$, respectivamente).

Os aquíferos apresentam uma grande variação relacionada às descontinuidades e espessuras das camadas. Isso indica diferentes cargas 
hidráulicas e ocorrência de aquíferos locais, embora se reconheça que os poços com profundidades diferentes também interceptam diferentes cargas hidráulicas, resultando em diferentes níveis potenciométricos, sem, entretanto, associar-se a outras unidades aquíferas.

$\mathrm{Na}$ Figura 33 observa-se que as altitudes máximas do nível d'água se localizam na porção oeste da área de estudo, onde predominam as águas do Aquífero Llío-Guano, enquanto as porções mais rebaixadas se localizam no leste em Cubijíes. A direção predominante do fluxo da água é de noroeste para nordeste (desde o Chimborazo até o rio Chambo) e de norte para o sul (desde o Igualata até o rio Guano). 


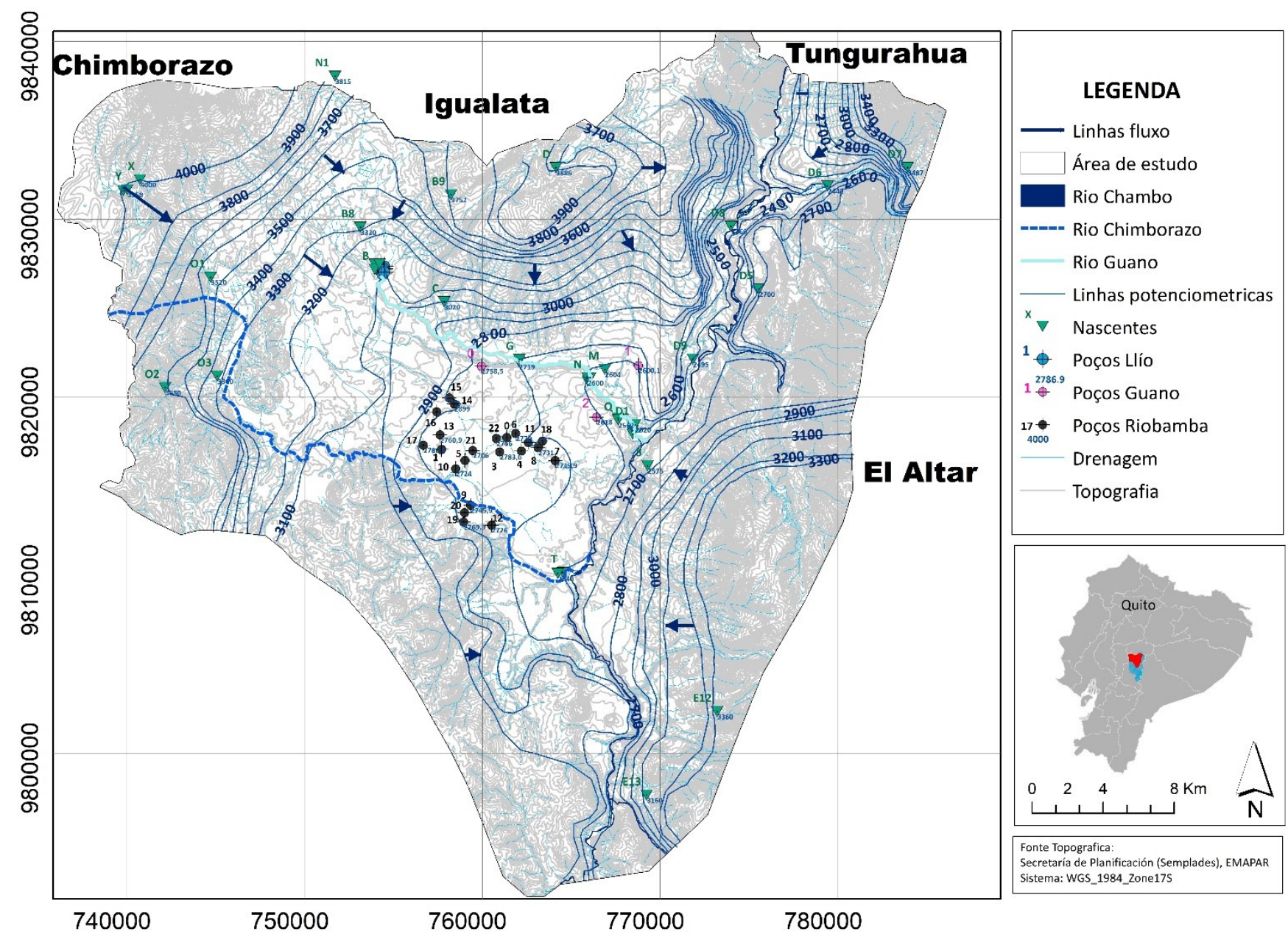

Figura 33. Potenciometria esquemática da zona de estudo. As direções preferenciais das águas subterrâneas ocorrem desde o Chimborazo e Igualata (cordilheira ocidental), El Altar e Tungurahua, (cordilheira oriental) para o rio Chambo. 


\subsection{Hidrogeoquímica}

A classificação hidrogeoquímica das águas subterrâneas considerou 13 amostras, três poços (Llío\#1, Llío\#3, Llío\#5) e sete nascentes (1 em San Pablo, 2 em Guano e 4 em Cubijíes) coletadas em agosto de 2016 e 3 poços $(1,15,19)$ coletados em 2017 (Figura 34, Tabela 14).

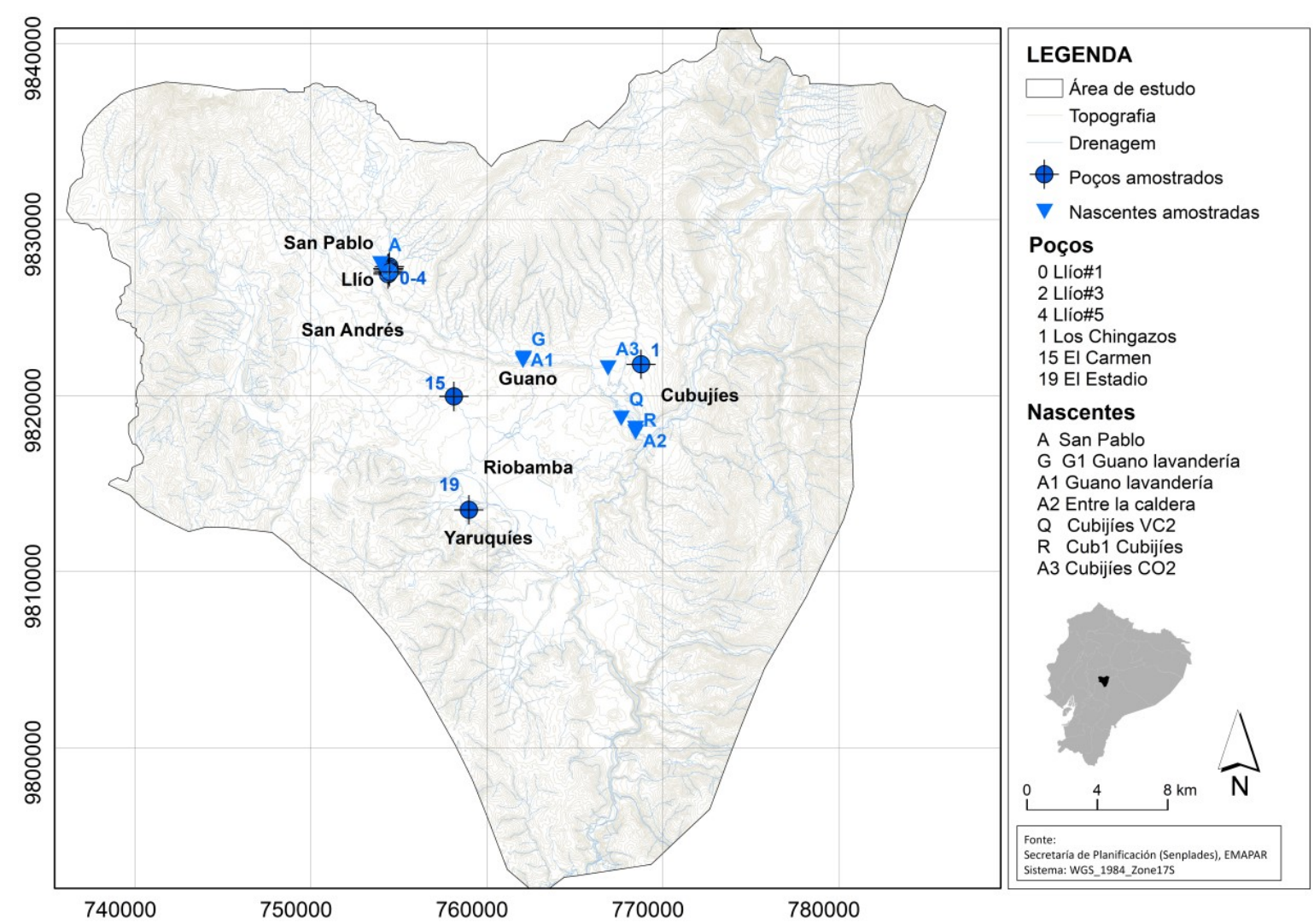

Figura 34. Localização dos pontos de amostragem (poços e nascentes) para a campanha de 2016.

Os resultados das análises físico-químicas e químicas das amostras de poços e nascentes indicaram a ocorrência de três tipos químicos predominantes de águas. O primeiro deles engloba as águas do Aquífero Llío-Guano e Riobamba (bicarbonatadas cálcio-magnesianas), o segundo as águas do Aquífero Yaruquíes (bicarbonatadas sódicas) e o terceiro as águas das nascentes de Cubijíes (sulfatadas-magnesianas) (Figura 35). 
Tabela 14. Dados dos poços tubulares e nascentes amostradas em 2016 e resultados físico-químicos das águas subterrâneas da área de estudo.

\begin{tabular}{|c|c|c|c|c|c|c|c|c|c|c|}
\hline \multirow{2}{*}{ Cód. } & \multirow{2}{*}{ Nome } & \multicolumn{2}{|c|}{ Coordenas UTM } & \multirow{2}{*}{$\begin{array}{c}\text { Cota } \\
(\mathrm{m})\end{array}$} & \multirow{2}{*}{${ }^{*} \mathrm{~A}$} & \multirow{2}{*}{$\begin{array}{l}\text { Prof. } \\
\text { (m) }\end{array}$} & \multirow{2}{*}{$\begin{array}{c}\text { CE } \\
(\mu \mathrm{S} / \mathrm{cm})\end{array}$} & \multirow{2}{*}{ pH } & \multirow{2}{*}{$\begin{array}{c}\text { Temp. } \\
\left({ }^{\circ} \mathrm{C}\right)\end{array}$} & \multirow{2}{*}{$\begin{array}{c}\text { Classificação } \\
\text { Piper }\end{array}$} \\
\hline & & $\mathbf{x}$ & $\mathbf{Y}$ & & & & & & & \\
\hline 0 & Llío\#1 PA1 & 754475 & 9827340 & 3134 & $\mathrm{~L}$ & 87,8 & 432,4 & 6,5 & 12,0 & $\mathrm{Mg}-\mathrm{Ca}-\mathrm{Na}-\mathrm{HCO}_{3}$ \\
\hline 2 & Llío\#3 PA3 & 754395 & 9827005 & 3102 & $\mathrm{~L}$ & 50 & 432,4 & 6,5 & 12,0 & $\mathrm{Mg}-\mathrm{Ca}-\mathrm{Na}-\mathrm{HCO}_{3}$ \\
\hline 4 & Llío\#5 & 754446 & 9827230 & 3119 & $\mathrm{~L}$ & 224 & 432,4 & 6,5 & 12,0 & $\mathrm{Mg}-\mathrm{Ca}-\mathrm{Na}-\mathrm{HCO}_{3}$ \\
\hline 1 & Los Chingazos & 768776 & 9821784 & 2720 & G & 227 & 1279,3 & 7,1 & 20,5 & $\mathrm{Na}-\mathrm{Mg}-\mathrm{HCO}_{3}$ \\
\hline 15 & El Carmen & 758140 & 9819959 & 2890 & $\mathrm{R}$ & 243,3 & 1320,9 & 7,5 & 18,3 & $\mathrm{Mg}-\mathrm{Ca}-\mathrm{Na}-\mathrm{HCO}_{3}$ \\
\hline 19 & El Estadio & 758994 & 9813514 & 2815 & $\mathrm{Y}$ & 200 & 1695,7 & 7,5 & 22,8 & $\mathrm{Na}-\mathrm{HCO}_{3}$ \\
\hline A & San Pablo & 753960 & 9827473 & 3120 & $\mathrm{~L}$ & & 479,3 & 5,3 & 10,9 & $\mathrm{Mg}-\mathrm{Ca}-\mathrm{Na}-\mathrm{HCO}_{3}$ \\
\hline G & G1 Guano lav. & 762081 & 9822111 & 2700 & G & & 675,6 & 5,7 & 15,4 & $\mathrm{Mg}-\mathrm{Ca}-\mathrm{Na}-\mathrm{HCO}_{3}$ \\
\hline A1 & Guano lavanderia & 762054 & 9821991 & 2719 & G & & 675,6 & 5,7 & 15,4 & $\mathrm{Mg}-\mathrm{Ca}-\mathrm{Na}-\mathrm{HCO}_{3}$ \\
\hline A2 & Entre la caldera & 767626 & 9818816 & 2555 & C & & 1415,1 & 7,4 & 19,6 & $\mathrm{Mg}-\mathrm{Na}-\mathrm{Ca}-\mathrm{SO}_{4}-\mathrm{HCO}_{3}$ \\
\hline Q & Cubijíes VC2 & 767644 & 9818696 & 2562 & C & & 1415,1 & 7,4 & 19,6 & $\mathrm{Mg}-\mathrm{Na}-\mathrm{Ca}-\mathrm{SO}_{4}-\mathrm{HCO}_{3}$ \\
\hline $\mathrm{R}$ & CUB1 Cubijíes & 768456 & 9817915 & 2504 & C & & 1415,1 & 7,4 & 19,6 & $\mathrm{Mg}-\mathrm{Na}-\mathrm{Ca}-\mathrm{SO}_{4}-\mathrm{HCO}_{3}$ \\
\hline A3 & Cubijíes CO2 & 766886 & 9821554 & 2604 & C & & 1415,1 & 7,4 & 19,6 & $\mathrm{Mg}-\mathrm{Na}-\mathrm{Ca}-\mathrm{SO} 4-\mathrm{HCO}_{3}$ \\
\hline
\end{tabular}


Os parâmetros físicos de condutividade elétrica (CE), pH e temperatura mostram variações na sua distribuição espacial, principalmente entre as águas dos Aquíferos Llío-Guano e as do Aquífero Yaruquíes e as nascentes de Cubijíes. De uma maneira geral a $\mathrm{CE}, \mathrm{o} \mathrm{pH}$ e a temperatura seguem um padrão espacial similar, posto que seus valores são mais elevados nas águas do Aquífero Yaruquíes e nas águas das nascentes de Cubijíes que nas águas do Aquífero Llío-Guano (Tabela 14).

Os principais íons das águas do Aquífero Llío-Guano e Yaruquíes também mostraram variações. As maiores concentrações de sódio na $\mathrm{BBRCH}$ correspondem às águas do poço 19 do Aquífero Yaruquíes e das nascentes de Cubijíes (Tabela 15).

As águas sódicas do Aquífero Yaruquíes e as águas sulfatadas das nascentes de Cubijíes estariam associadas às águas de ambientes vulcânicos. Alguns autores (Kebede, et al., 2008); (Foster, 2012) apontam que as águas deste tipo são indicativas desses ambientes. 
Tabela 15. Resultados analíticos químicos (concentração em mg/L) das amostras coletadas em agosto de 2016 e 2017.

\begin{tabular}{|c|c|c|c|c|c|c|c|c|c|c|c|c|c|c|}
\hline Cód. & $\mathrm{HCO}_{3}{ }^{-}$ & $\mathrm{SO}_{4}^{-2}$ & $\mathrm{HPO}_{4}^{-2}$ & $\mathrm{Cl}^{-}$ & $\mathrm{Br}^{-}$ & $F^{-}$ & $\mathrm{NO}_{3}{ }^{-}$ & $\mathrm{NO}_{2}^{-}$ & $\mathrm{Na}^{+}$ & $\mathrm{K}^{+}$ & $\mathrm{Li}^{+}$ & $\mathrm{Ca}^{+2}$ & $\mathrm{Mg}^{+2}$ & $\mathrm{NH}_{4}{ }^{+}$ \\
\hline 0 & 207,91 & 21,65 & 0,48 & 4,83 & 1,06 & 1,15 & 12,78 & 0,004 & 25,36 & 3,68 & 0,011 & 28,04 & 26,94 & 0,02 \\
\hline 2 & 233,98 & 24,85 & 0,72 & 5,99 & 0,98 & 1,14 & 22,61 & 0,013 & 31,74 & 3,64 & 0,015 & 29,57 & 31,42 & 0,03 \\
\hline 4 & 315,75 & 18,77 & 0,99 & 6,82 & 1,62 & 0,95 & 12,77 & 0,007 & 32,25 & 3,71 & 0,02 & 30,40 & 45,42 & 0,03 \\
\hline A & 174,79 & 35,85 & 0 & 5,69 & 1,37 & 0,73 & 9,15 & 0,013 & 24,70 & 3,18 & 0,014 & 27,18 & 23,55 & 0,006 \\
\hline 15 & 408 & 269 & & 2,8 & & & & & 64,2 & & & 80 & 93,3 & \\
\hline 19 & 600 & 273 & & 82,2 & & & & & 190,2 & 17,24 & & 35,43 & 18,11 & \\
\hline G & 372,83 & 50,30 & 0,85 & 14,06 & 1,85 & 1,01 & 11,75 & 0,016 & 43,88 & 4,06 & 0,018 & 45,72 & 54,35 & 0,05 \\
\hline A1 & 372,83 & 52,16 & 0,96 & 14,14 & 1,55 & 1,18 & 11,86 & 0,03 & 44,25 & 4,05 & 0,017 & 48,66 & 55,77 & 0,03 \\
\hline A2 & 477,14 & 396,11 & 0,83 & 17,24 & 1,59 & 2,52 & 8,21 & 0,015 & 145,39 & 9,56 & 0,04 & 71,52 & 99,82 & 0,28 \\
\hline$Q$ & 347,46 & 614,33 & 0,23 & 14,12 & 0,75 & 2,53 & 12,01 & 0,017 & 139,44 & 7,17 & 0,05 & 81,86 & 118,84 & 0,27 \\
\hline $\mathrm{R}$ & 458,11 & 389,82 & 0,65 & 16,94 & 1,30 & 2,73 & 8,16 & 0,013 & 143,06 & 9,73 & 0,04 & 69,24 & 97,74 & 0,27 \\
\hline A3 & 359,44 & 547,71 & 0,34 & 14,83 & 0,94 & 2,37 & 7,14 & 0,22 & 93,33 & 7,78 & 0,05 & 80,39 & 122,66 & 0,016 \\
\hline
\end{tabular}




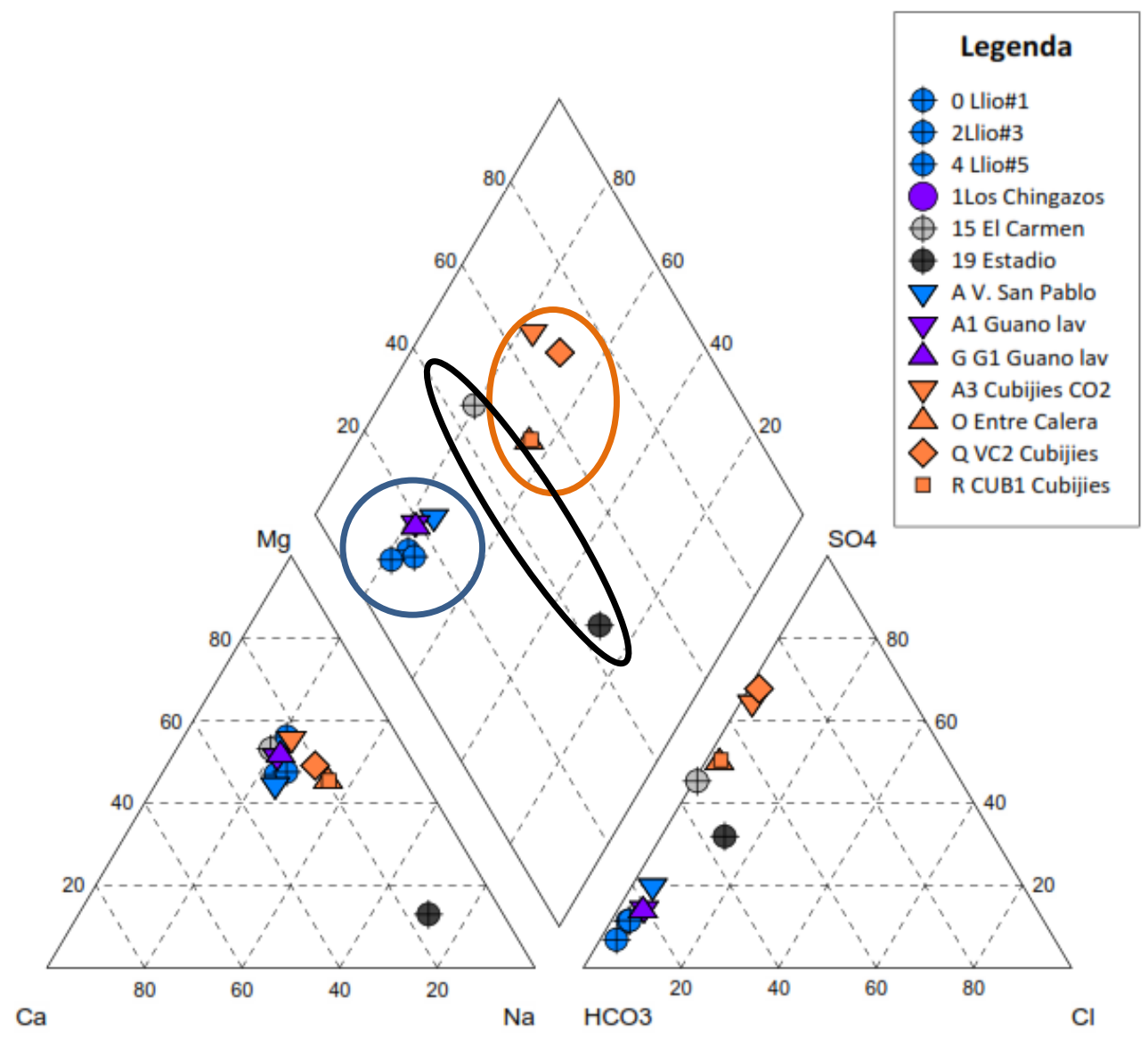

Figura 35. Diagrama de Piper e classificação das águas na $B B R C H$. A análise contempla os poços (círculos) e as nascentes (triângulos) nas localidades de Llío (círculos azuis), San Pablo (triângulos azuis), Guano (triângulos lilás), Cubijíes (triângulos marrons) e Riobamba (círculos cinza) e Yaruquíes (círculos cinza escuro).

\subsubsection{Análises isotópicas}

Os resultados das análises isotópicas de $\delta^{18} \mathrm{O}$ e $\delta^{2} \mathrm{H}$ compreenderam 17 amostras de poços e nascentes (Tabela 16). Foram obtidas as razões isotópicas de águas coletadas em poços tubulares e nascentes em duas campanhas de amostragem: novembro de 2016 (10 amostras: 3 poços e 7 nascentes) e maio de 2017 (7 amostras: 4 poços e 3 nascentes). As campanhas de amostragens não contemplaram os mesmos pontos devido às dificuldades apresentadas nas permissões dos proprietários para a coleta. 
Tabela 16. Resultados das análises de $\delta^{18} \mathrm{O} \%$ e $\delta^{2} \mathrm{H} \%$ das amostras coletadas nas localidades de Llío, Guano, Riobamba e Cubijíes.

\begin{tabular}{|c|c|c|c|c|c|c|}
\hline Cód. & $\begin{array}{l}\text { Quant. de } \\
\text { Amostras }\end{array}$ & Nome & Localização & $\begin{array}{l}\text { Data } \\
\text { coleta }\end{array}$ & $\delta^{18} \mathrm{O} \%$ & $\delta^{2} \mathrm{H} \%$ \\
\hline 0 & \multirow{4}{*}{$\begin{array}{c}4 \text { amostras: } \\
3 \text { poços; } 1 \\
\text { nascente }\end{array}$} & llío\#1 & Llío & $21 / 11 / 2016$ & $-13,10$ & $-94,90$ \\
\hline 2 & & llío\#3 & Llío & $21 / 11 / 2016$ & $-13,01$ & $-94,50$ \\
\hline 4 & & llío\#5 & Llío & $21 / 11 / 2016$ & $-12,95$ & $-93,90$ \\
\hline A & & San Pablo & San Pablo & $21 / 11 / 2016$ & $-13,50$ & $-97,20$ \\
\hline A1 & \multirow{3}{*}{$\begin{array}{l}2 \text { amostras: } \\
2 \text { nascentes }\end{array}$} & $\begin{array}{l}\text { Guano } \\
\text { Lavanderia }\end{array}$ & Guano & $21 / 11 / 2016$ & $-12,86$ & $-93,80$ \\
\hline $\mathrm{G}$ & & G1 Guano & Guano & $21 / 11 / 2016$ & $-12,89$ & $-94,00$ \\
\hline $\mathrm{T}$ & & Pantaño & Rio Chibunga & $30 / 05 / 2017$ & $-11,09$ & $-82,10$ \\
\hline 4 & \multirow{5}{*}{$\begin{array}{c}5 \text { amostras: } \\
4 \text { poços; } 1 \\
\text { nascente }\end{array}$} & UNACH & Riobamba & $30 / 05 / 2017$ & $-10,87$ & $-79,50$ \\
\hline 11 & & 21 de abril & Riobamba & $30 / 05 / 2017$ & $-12,71$ & $-95,60$ \\
\hline 13 & & 24 de mayo & Riobamba & $30 / 05 / 2017$ & $-12,88$ & $-96,30$ \\
\hline 19 & & Estadio & Yaruquíes & $30 / 05 / 2017$ & $-11,34$ & $-89,90$ \\
\hline $\mathrm{R}$ & & CUB1 & Cubijíes & $21 / 11 / 2016$ & $-10,99$ & $-85,10$ \\
\hline A3a & \multirow{4}{*}{$\begin{array}{l}6 \text { amostras: } \\
6 \text { nascentes }\end{array}$} & Cubijíes CO2 & Cubijíes & $21 / 11 / 2016$ & $-11,15$ & $-86,90$ \\
\hline$Q$ & & VC2 & Cubijíes & $21 / 11 / 2016$ & $-11,17$ & $-87,10$ \\
\hline $\mathrm{A} 3 \mathrm{~b}$ & & Cubijíes CO2 & Cubijíes & $30 / 05 / 2017$ & $-11,2$ & $-87,00$ \\
\hline${ }^{*} \mathrm{~A} 2 \mathrm{a}$ & & VCLavandería & Cubijíes & $30 / 05 / 2017$ & $-10,96$ & $-84,60$ \\
\hline${ }^{*} \mathrm{~A} 2 \mathrm{~b}$ & & VCLavandería & Cubijíes & $21 / 11 / 2016$ & $-10,93$ & $-84,50$ \\
\hline
\end{tabular}

Cód.=código da amostra. Equipamento Picarro $\pm 0,09$ para $\delta^{18} \mathrm{O}$ e $\pm 0,9$ para $\delta^{2} \mathrm{H} .{ }^{*} \mathrm{~A} 2 \mathrm{a}, \mathrm{A} 2 \mathrm{~b}, \mathrm{~A} 3 \mathrm{a}, \mathrm{A} 3 \mathrm{~b}$ : amostra da mesma nascente coletada em diferentes datas.

De forma geral, as razões isotópicas de $\delta^{18} \mathrm{O}$ e $\delta^{2} \mathrm{H}$ das águas de poços e nascentes coletadas no Aquífero de Llío-Guano diferem das amostras de água dos aquíferos Riobamba, Yaruquíes e das águas das nascentes de Cubijíes, tendo a maior variação da razão isotópica as amostras de água do Aquífero LlíoGuano com as amostras de água das nascentes de Cubijíes (Tabela 16).

Ao comparar as razões isotópicas das nascentes de San Pablo, Guano, Pantaño e Cubijíes, observa-se que as primeiras (San Pablo e Guano, localizadas mais próximas ao vulcão Chimborazo) são mais empobrecidas que 
as localizadas mais distantes do vulcão Chimborazo e mais próximas ao vulcão El Altar (nascentes T, R, Q, A2, A3).

O mesmo efeito, observa-se nas assinaturas isotópicas das águas dos poços do Aquífero Llío-Guano, Riobamba e Yaruquíes. Os valores de $\delta^{18} \mathrm{O}$ e $\delta^{2} \mathrm{H}$ para as águas dos poços de Llío e Riobamba variam, sendo as mais empobrecidas as águas referentes aos poços do Aquífero Llío-Guano (Tabela 16, Figura 36).

As razões isotópicas de $\delta^{18} \mathrm{O}$ e $\delta^{2} \mathrm{H}$ dos poços 4 (Aquífero de Riobamba) e 19 (Aquífero de Yaruquíes) diferem das razões isotópicas dos poços localizados no Aquífero de Riobamba (2, 5, 11 e 13), a pesar de que os poços do Aquífero de Riobamba possuírem profundidade de captação muito similares (entre 175 e $200 \mathrm{~m})$.

A figura 36 mostra a relação isotópica entre $\delta{ }^{2} \mathrm{H}$ e $\delta^{18} \mathrm{O}$ para as águas subterrâneas localizadas na $\mathrm{BBRCH}$, indicando nitidamente dois grupos. $\mathrm{O}$ grupo 1 correspondente as amostras dos poços do Aquífero Llío-Guano $(0,2,4)$, aquífero de Riobamba (2, 5, 11 e 13) e a nascente San Pablo (A) e estão localizadas próximas à reta meteórica global. Já as amostras de água correspondentes ao grupo 2, constituídas pelas águas dos poços do Aquífero Riobamba (4), Aquífero Yaruquíes (19) e as águas das amostras das nascentes de Cubijíes, estão localizadas baixo da reta meteórica global, mostrando águas mais enriquecidas.

A Figura 37 mostra a relação de $\delta^{18} \mathrm{O}$ com a altitude, observa-se que existe uma diferença de aproximadamente $500 \mathrm{~m}$ entre as amostras do grupo $1 \mathrm{e}$ as do grupo 2. A diferença em $\delta^{18} \mathrm{O}$ é de aproximadamente $1,8 \%$, o que corrobora a existência marcada de dois grupos de águas na área de estudo.

Os resultados das análises isotópicas são coincidentes com os resultados mostrados nos parâmetros físicos e químicos descritos na seção anterior. A ocorrência dos tipos de águas com características físicas, químicas e isotópicas diferentes evidenciam das fontes de águas diferentes. Estas fontes poderiam estar localizadas no vulcão Chimborazo e El Altar. Este último, pode ser o responsável das altas concentrações de sulfato e sódio nas águas do Aquífero Yaruquíes e nas nascentes de Cubijíes, refletindo uma forte influência de vulcanismo ou hidrotermal. Corroboram com essa avaliação o fato das águas 
sulfatadas e sódicas terem maior temperatura que aquelas relacionadas às águas provindas dos vulcões a oeste, bem como a nítida variação nas razoes isotópicas.

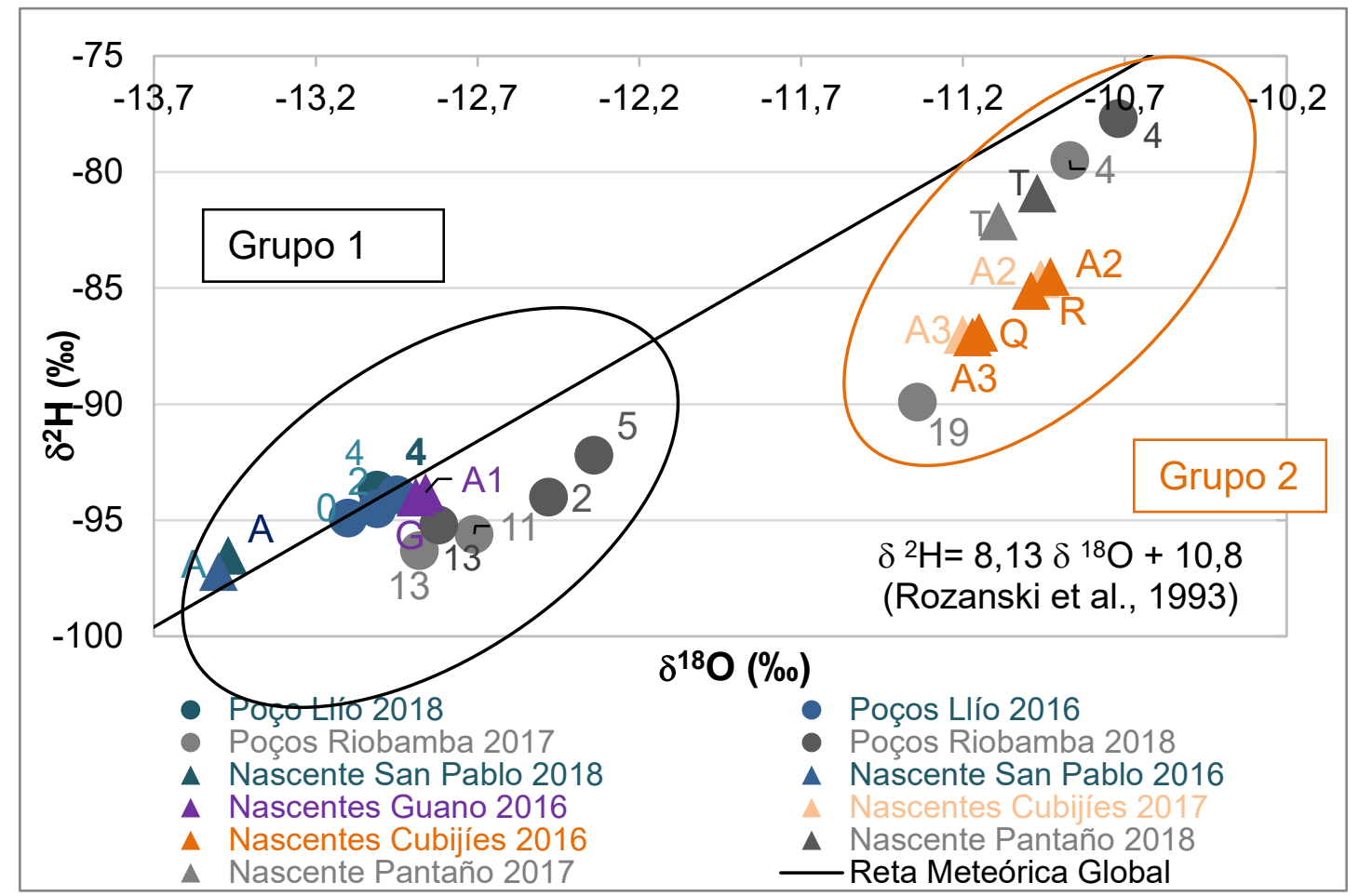

Figura 36. Relação isotópica entre $\delta^{18} \mathrm{O}$ e $\delta^{2 H}$ para as águas subterrâneas localizadas na $B B R C H$.

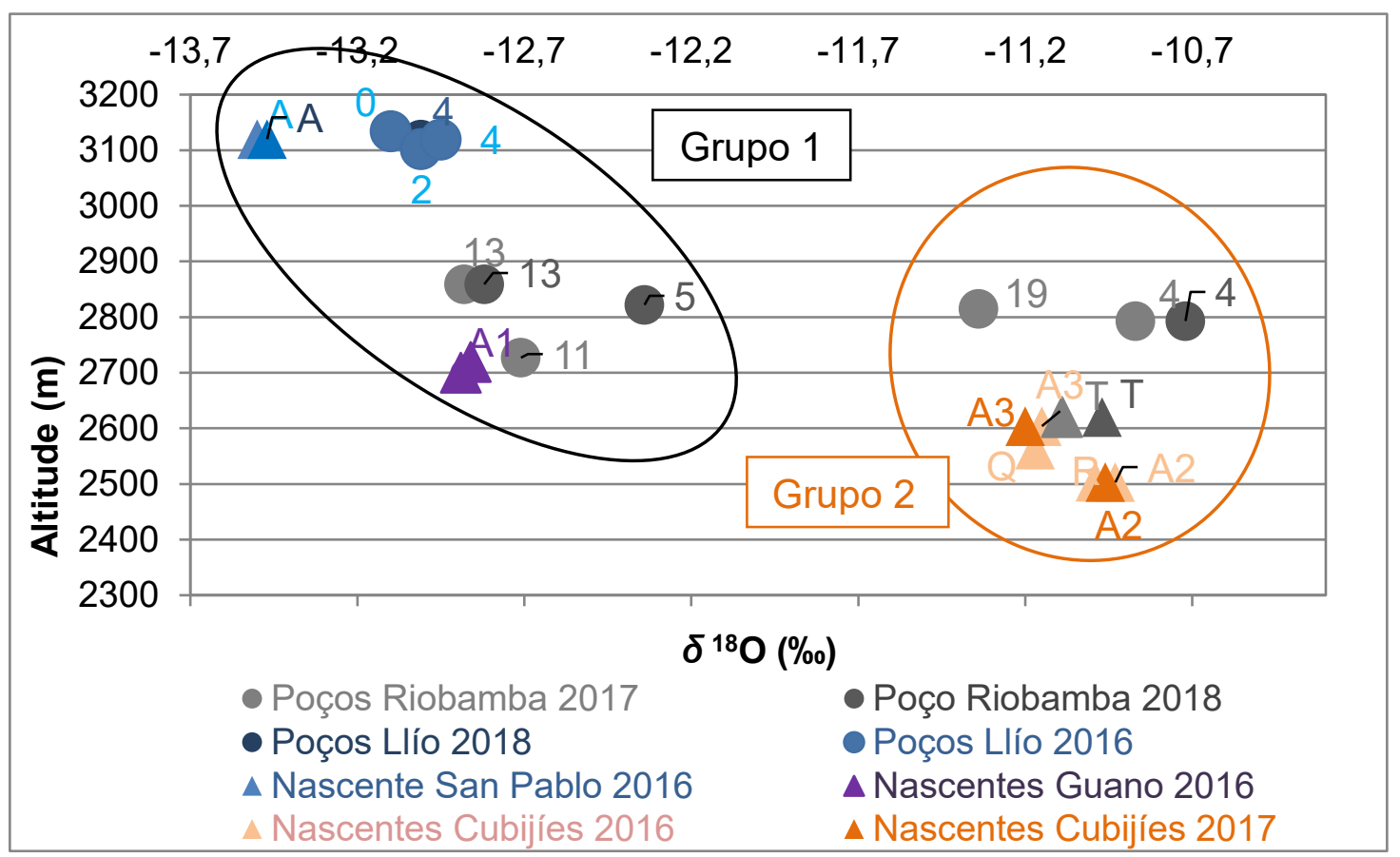

Figura 37. Relação isotópica entre a altitude e $\delta^{18} \mathrm{O}$ para as águas subterrâneas localizadas na BBRCH. 
Para estabelecer a reta meteórica local é necessário coletar amostras mensais de água de chuva no mínimo em um ano hidrológico, no entanto, nesta pesquisa foram coletadas amostras de 8 meses desde outubro de 2016 até maio de 2017, com um total de 24 amostras, para avaliar a tendência dos valores de $\delta^{18} \mathrm{O}$ e $\delta^{2} \mathrm{H}$ e estabelecer as possíveis retas meteóricas para as águas das chuvas em Ilapo, Guano e Riobamba. Atualmente, estão sendo coletadas as amostras mensais de água da chuva para completar uma série de pelo menos um ano hidrológico e estabelecer a reta meteórica local.

Os valores de $\delta^{18} \mathrm{O}$ e $\delta^{2} \mathrm{H}$ para as águas das chuvas no período de 8 meses amostrados variam de $-21,17$ a $-7,48 \%$ e de $-157,60$ a $-49,00 \%$, respectivamente (Tabela 17). As retas meteóricas para as três localidades foram obtidas ao ajustar uma reta na distribuição dos pontos formados pela relação entre os valores de $\delta^{18} \mathrm{O}$ e $\delta^{2} \mathrm{H}$ das águas das chuvas em cada estação. As retas meteóricas de Ilapo, Guano e Riobamba, para o período monitorado localizamse sobre a reta meteórica global (Rozanski, Araguás \& Gonfiantini, 1993), tanto quanto sobre a reta meteórica de Quito (Manciati, 2014). Ou seja, as chuvas nas regiões de llapo, Guano e Riobamba correlacionam-se às chuvas mundiais e da cidade de Quito (Figura 38).

Considerando as águas das chuvas das três estações que correspondem ao período de estiagem (dezembro de 2016 a fevereiro de 2017) observa-se que essas águas se tornam mais enriquecidas $\left(-14,27 \%\right.$ e $-7,48 \%$, para $\delta^{180}$, e $103,10 \%$ e $-49,50 \%$, para $\delta^{2} \mathrm{H}$ ) quando comparadas com amostras coletadas no período chuvoso (outubro a novembro de 2016 e março a maio de 2017). Caso a origem da umidade seja a mesma ao longo do ano, isso se atribuiria ao efeito quantidade (Figura 38).

Ao plotar os valores das razões isotópicas das águas coletadas nas neves do Chimborazo, por La Frenierre (2014), evidencia-se que tanto as águas da chuva quanto as águas do Chimborazo obedecem às águas mundiais e da chuva de Quito, o que dificulta a determinação da fonte de recarga das águas superficiais e subterrâneas na área de estudo (Figura 38). 
Tabela 17. Razões isotópicas das águas de chuvas mensais (10/2016 a 05/2017) e do degelo do Chimborazo amostrado por La Frenierre (2014).

\begin{tabular}{|c|c|c|c|c|c|}
\hline Cód. Amostra & Nome & Data & $\delta^{18} \mathrm{O} \%$ & $\delta^{2} \mathrm{H} \%$ & Volume chuva (mm) \\
\hline li & Ilapo & $14 / 10 / 2016$ & $-10,91$ & $-73,5$ & 56,7 \\
\hline li & Ilapo & $17 / 11 / 2016$ & $-8,34$ & $-51,5$ & 41 \\
\hline IV & Ilapo & $15 / 12 / 2016$ & -8 & -49 & 27 \\
\hline IV & Ilapo & $18 / 01 / 2017$ & $-14,27$ & $-103,1$ & 86,5 \\
\hline IV & Ilapo & $15 / 02 / 2017$ & $-8,72$ & $-56,7$ & 41,3 \\
\hline li & Ilapo & $15 / 03 / 2017$ & $-13,4$ & $-93,4$ & 130,4 \\
\hline li & Ilapo & $13 / 04 / 2017$ & $-19,37$ & $-142,4$ & 161,7 \\
\hline li & Ilapo & $15 / 05 / 2017$ & $-21,17$ & $-157,6$ & 127,3 \\
\hline \multicolumn{3}{|c|}{ Mínima (10/2016 a 05/2017) } & $-21,17$ & $-157,6$ & 27 \\
\hline \multicolumn{3}{|c|}{ Máxima (10/2016 a 05/2017) } & -8 & -49 & 161,7 \\
\hline $\mathrm{Gi}$ & Guano & $14 / 10 / 2016$ & $-9,4$ & $-64,3$ & 29,1 \\
\hline $\mathrm{Gi}$ & Guano & $17 / 11 / 2016$ & $-8,43$ & $-53,6$ & 27,2 \\
\hline Gv & Guano & $15 / 12 / 2016$ & $-7,57$ & $-51,2$ & 19 \\
\hline Gv & Guano & $15 / 02 / 2017$ & $-7,48$ & $-49,5$ & 55,5 \\
\hline $\mathrm{Gi}$ & Guano & $15 / 03 / 2017$ & $-13,32$ & $-97,1$ & 90,5 \\
\hline $\mathrm{Gi}$ & Guano & $13 / 04 / 2017$ & $-18,21$ & $-135,3$ & 153,2 \\
\hline $\mathrm{Gi}$ & Guano & $15 / 05 / 2017$ & $-19,14$ & $-144,7$ & 89,8 \\
\hline \multicolumn{3}{|c|}{ Mínima (10/2016 a 05/2017) } & $-19,14$ & $-144,7$ & 19 \\
\hline \multicolumn{3}{|c|}{ Máxima (10/2016 a 05/2017) } & $-7,48$ & $-49,5$ & 153,2 \\
\hline $\mathrm{Ri}$ & Riobamba & $14 / 10 / 2016$ & $-9,21$ & $-64,7$ & 48,63 \\
\hline $\mathrm{Ri}$ & Riobamba & $17 / 11 / 2016$ & $-8,03$ & $-50,9$ & 32,5 \\
\hline $\mathrm{Rv}$ & Riobamba & $15 / 12 / 2016$ & $-7,82$ & $-51,1$ & 37,8 \\
\hline $\mathrm{Rv}$ & Riobamba & $18 / 01 / 2017$ & $-11,98$ & $-88,9$ & 84,5 \\
\hline $\mathrm{Rv}$ & Riobamba & $15 / 02 / 2017$ & $-8,23$ & -54 & 29,1 \\
\hline $\mathrm{Ri}$ & Riobamba & $15 / 03 / 2017$ & $-12,1$ & $-85,3$ & 156 \\
\hline $\mathrm{Ri}$ & Riobamba & $13 / 04 / 2017$ & $-18,77$ & $-139,2$ & 126,1 \\
\hline $\mathrm{Ri}$ & Riobamba & $15 / 05 / 2017$ & $-19,87$ & -148 & 87,5 \\
\hline \multicolumn{3}{|c|}{ Mínima (10/2016 a 05/2017) } & $-19,87$ & -148 & 29,1 \\
\hline \multicolumn{3}{|c|}{ Máxima (10/2016 a 05/2017) } & $-7,82$ & $-50,9$ & 156 \\
\hline \multicolumn{3}{|c|}{ Gelo D. Ch. (La Frenierre, 2014) } & $-13,5$ & -92 & \\
\hline \multicolumn{3}{|c|}{ Gelo 1 Ch. (La Frenierre, 2014) } & $-13,6$ & -96 & \\
\hline \multicolumn{3}{|c|}{ Gelo 2 Ch. (La Frenierre, 2014) } & $-12,8$ & -95 & \\
\hline
\end{tabular}



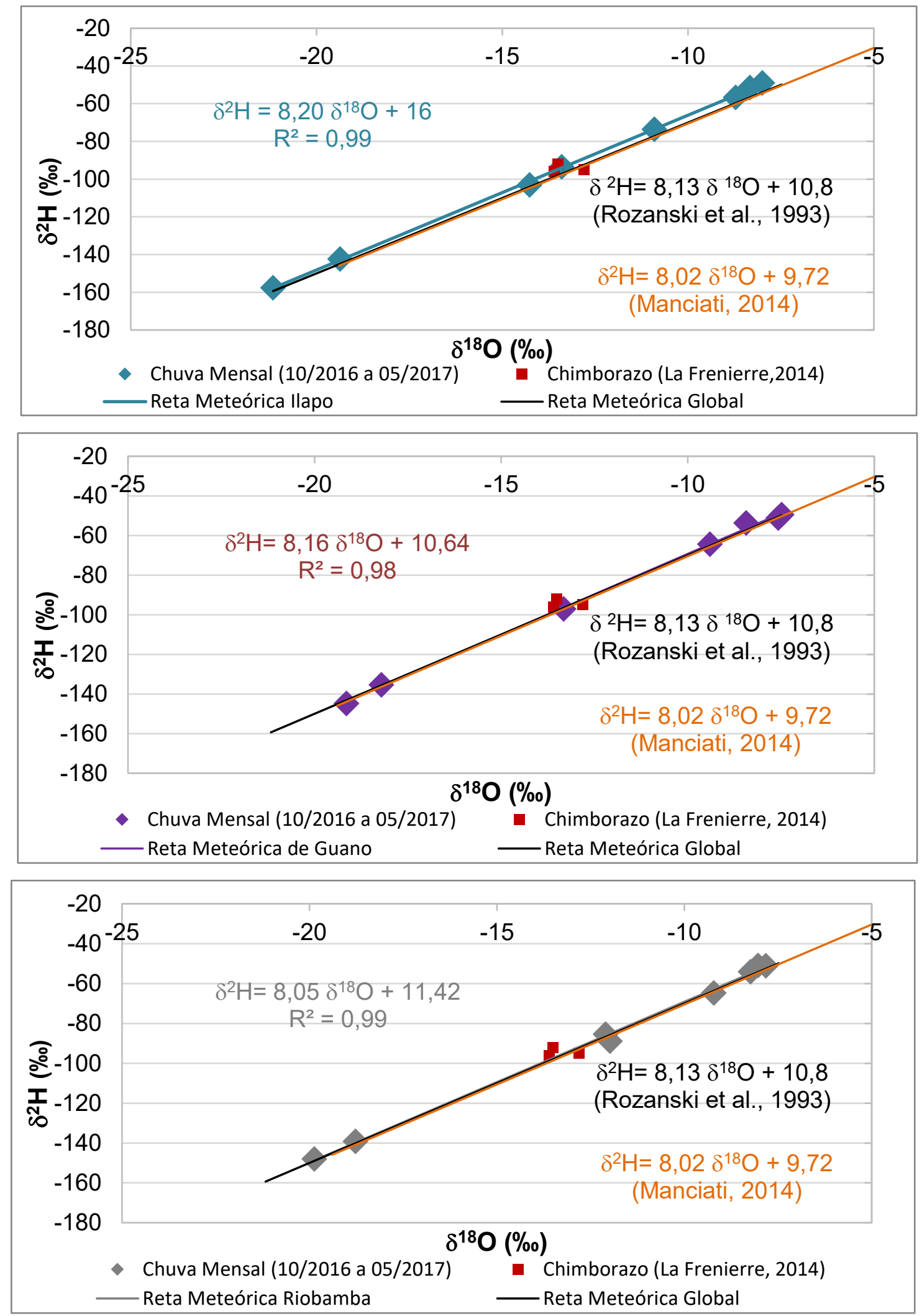

Figura 38. Relação isotópica entre $\delta^{18} \mathrm{O}$ e $\delta^{2} \mathrm{H}$ das águas da chuva nas localidades: a) Ilapo, b) Guano e c) Riobamba no período de 8 meses (10/2016 a 05/2017). 


\subsection{Modelo Hidrogeológico Conceitual}

O fluxo regional das águas subterrâneas segue a topografia e a drenagem, movimentando-se desde as porções mais elevadas (vulcões da Cordilheira Ocidental e Oriental) para as mais rebaixadas (vales de Guano e Riobamba até o rio Chambo). As maiores cotas estão a 4000 m.s.n.m (nascentes do Chimborazo) e as mínimas junto ao rio Chibunga, 2600 m.s.n.m (nascente T) e ao povoado de Cubijíes (nascente $Q$ ).

A recarga dos aquíferos ocorre principalmente pela influência da zona 1, pelo derretimento da maior geleira do Equador (Chimborazo) que contribui com a maior quantidade de água para área de estudo. Seja esta por escoamento superficial ou por recarga no aquífero. Além disso, existe a contribuição do Igualata, na recarga local, das águas que provêm das geleiras do vulcão El Altar e possivelmente das elevações da Cordilheira Oriental, assim como das precipitações que têm influência amazônica ao leste (Figura 39). Estas contribuições são as chaves para avaliar os armazenamentos e os fluxos superficiais e subterrâneos.

A morfologia da BBRCH influencia as superfícies potenciométricas e os divisores das microbacias hidrográficas e são coincidentes com as das águas subterrâneas. Baseado nos dados obtidos da geologia, hidrologia e hidroquímica, conclui-se que todas as contribuições descritas acima descarregam no rio Chambo, que flui do sul para o norte (Figura 39).

A ocorrência das águas subterrâneas na $\mathrm{BBRCH}$ está em domínio de depósitos vulcânicos do Chimborazo e Igualata, representados pelos fluxos de lava Chimborazo, Formação Riobamba, Yaruquíes e Cizarán, principalmente. Deve-se notar que na $\mathrm{BBRCH}$ existem estruturas regionais com dinâmica complexa que podem ajudar no transporte e circulação de águas subterrâneas tanto a oeste (Falla Pallatanga) quanto a leste (zona de cisalhamento, falha Peltetec) e na porção central (lineamento Guano - Altar, Chibunga - rio Ulpán, Calera - Urbina) da área de estudo (Figura 39). Nesse contexto geológico, ocorrem três aquíferos do tipo multicamadas, denominados: Llío-Guano, Riobamba e Yaruquíes-Cubijíes. Em geral, os três têm porosidade dupla, mas suas águas diferem na composição química e isotópica, conforme discutido nas seções anteriores. 


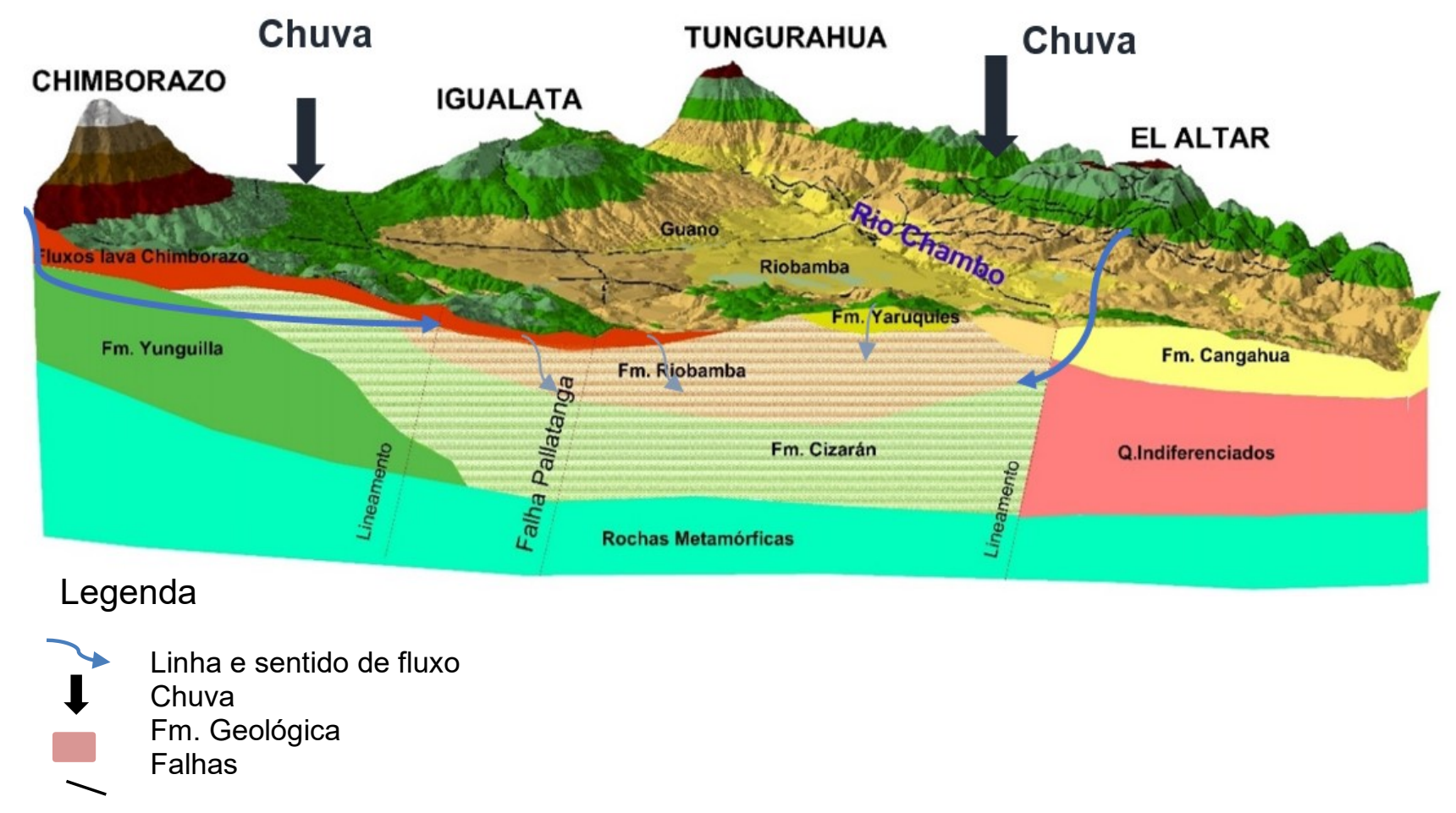

Figura 39. Modelo hidrogeológico esquemático conceitual da BBRCH.

\subsection{Proposta de gestão de recursos hídricos na área de estudo}

O zoneamento do meio físico da BBRCH constituiu uma ferramenta básica para subsidiar a gestão de recursos hídricos. Em cada zona avaliou-se a oferta instalada, ou seja, o quanto de água as estruturas de engenharia, incluindo os poços e as nascentes, podem oferecer no presente momento e a demanda de água para os diferentes usos consuntivos- agrícola, dessedentação de animais (bebedouro), cultivo de peixes, abastecimento doméstico e industrial.

\subsubsection{Oferta e demanda de água na $B B R C H$}

O uso predominante de água no Equador é para a agricultura, pois representa $80 \%$ do volume utilizado, seguido do uso doméstico, com $13 \%$, e o industrial, com 7\% (SENAGUA, 2011). Igualmente, na BBRCH o volume de água mais utilizado corresponde à agricultura, com demandas de água para irrigação de $77 \%$, seguido do uso doméstico, com $18 \%$, e a indústria, com $5 \%$ (Figura 40 $a$ e b). 
a)

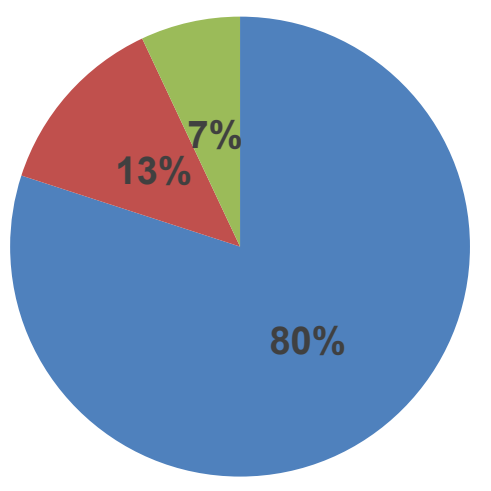

EQUADOR

- Uso agrícola b)

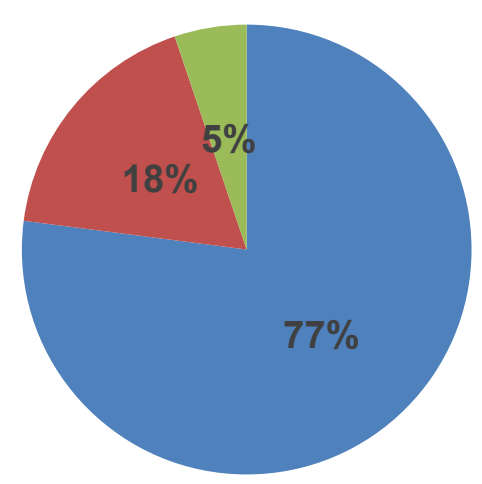

Figura 40. Demandas setoriais de água: a) no Equador e b) na $B B R C H$. Fonte: INEC, 2010).

Descreve-se a seguir as estimativas de demanda para os diferentes usos e de oferta superficial e subterrânea para cada uma das zonas.

A zona 1, com 5510,12 hectares cultivadas, demanda uma vazão mínima de água de 1,67 m³ para irrigação (Figura41). A Tabela 18 descreve as demandas de água por cada tipo de cultura e por hectares utilizadas.

Tabela 18. Demanda mínima de água requerida para irrigação na zona 1.

\begin{tabular}{llll}
\hline Cultura Hectares & $\begin{array}{c}\text { Demanda } \\
\text { mínima } \\
\left(\mathbf{m}^{3} / \mathbf{s}\right)\end{array}$ & $\begin{array}{c}\text { Demanda } \\
\text { máxima } \\
\left(\mathbf{m}^{3} / \mathbf{s}\right)\end{array}$ \\
\hline Milho & 2816,7 & 0,89 & 1,43 \\
Batata & 467,46 & 0,15 & 0,21 \\
Cereais & 1862,57 & 0,53 & 0,77 \\
Frutais & 363,39 & 0,09 & 0,18 \\
Total & 5510,12 & 1,67 & 2,59 \\
\hline
\end{tabular}

Para os outros usos, os valores de outorgas assinalam que a maior demanda é para uso industrial, com 2 outorgas (Tabela 19), incluindo a da maior indústria de cimento do Equador: Cimento Chimborazo. Esta empresa tem uma capacidade de produção de 3600 toneladas de cimento por dia. Sua produção satisfaz de $7 \%$ a $10 \%$ da demanda de cimento do país como registrado em 2013 
(EPCE, 2013). Para o seu funcionamento, a empresa necessita $0,88 \mathrm{~m}^{3} / \mathrm{s}$ (SENAGUA, 2012).

A demanda total de água nesta zona é de $3,41 \mathrm{~m}^{3} / \mathrm{s}$, para uma oferta total estimada de $4,84 \mathrm{~m}^{3} / \mathrm{s}$. Para a oferta superficial $\left(1,40 \mathrm{~m}^{3} / \mathrm{s}\right)$ foi considerada a vazão média dos rios menos $40 \%$ desse valor, correspondentes à vazão segura (vazão mínima para manter boas condições ecológicas, segundo Tennat (1976) (Anexo III). A oferta subterrânea é de $3,44 \mathrm{~m}^{3} / \mathrm{s}$ e considera as vazões das nascentes e a recarga lateral do Chimborazo e do Igualata, como foi exposto na seção 5.4 .

Tabela 19. Demanda e oferta estimada para a zona 1.

\begin{tabular}{|c|c|c|}
\hline Uso outorga & $\begin{array}{c}\text { Número } \\
\text { de } \\
\text { outorgas }\end{array}$ & $\begin{array}{c}\text { Demanda e } \\
\text { Oferta } \\
\left(\mathrm{m}^{3} / \mathrm{s}\right)\end{array}$ \\
\hline Irrigação estimada & & 1,66 \\
\hline Doméstico & 119 & 0,86 \\
\hline Dessedentação de animais & 45 & 0,016 \\
\hline $\begin{array}{l}\text { Demanda industrial } \\
\text { Cimento Chimborazo }\end{array}$ & 1 & 0,88 \\
\hline Demanda Total & 165 & 3,41 \\
\hline Oferta potencial superficial & & 1,40 \\
\hline Oferta instalada subterrânea & & 3,44 \\
\hline Oferta Total & & 4,84 \\
\hline
\end{tabular}




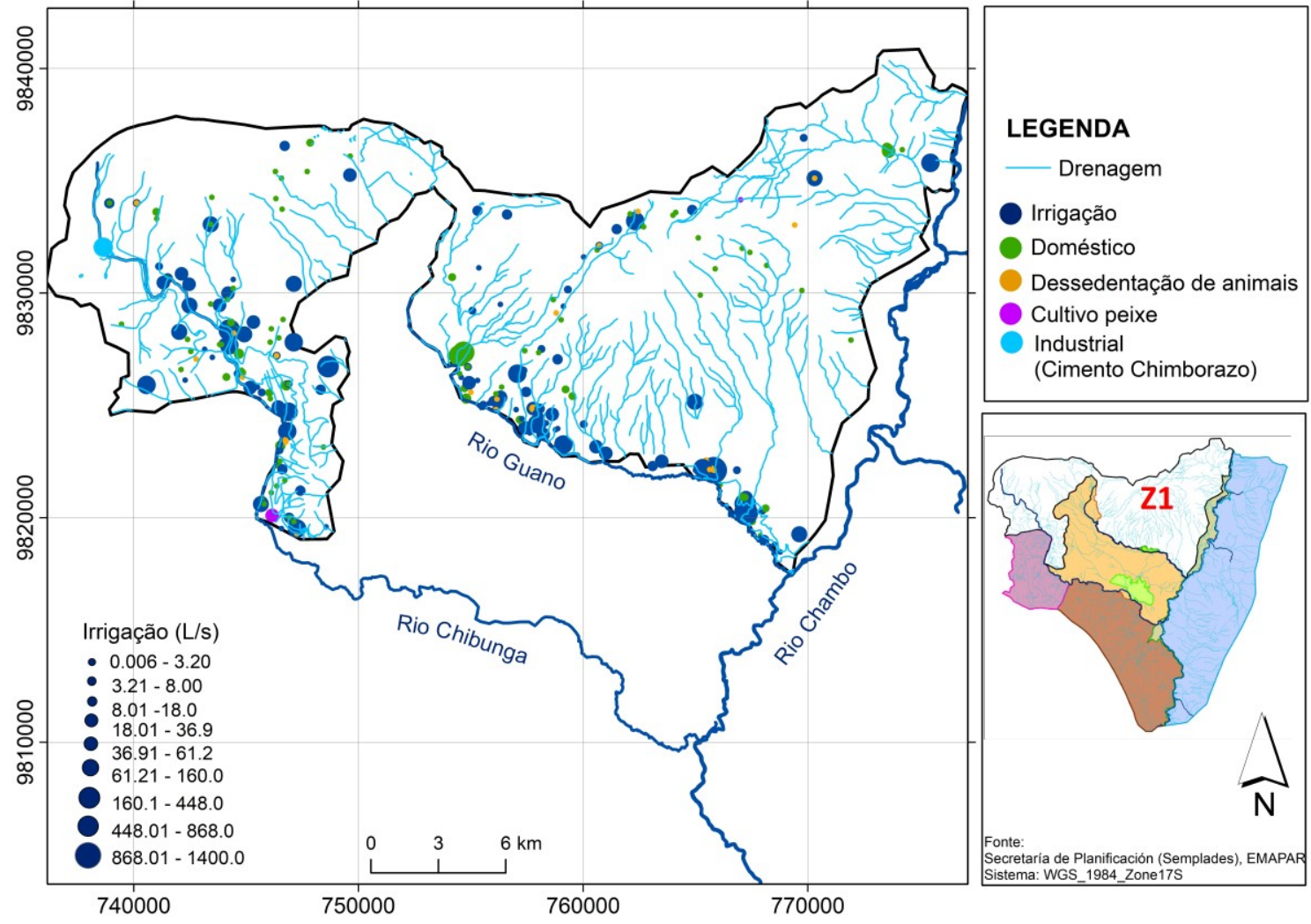

Figura 41. Demandas setoriais na zona 1, que mostra as outorgas com suas vazões e os diferentes usos.

Na zona 2, a maior demanda de água é requerida pelo setor agrícola com 2,57 $\mathrm{m}^{3} / \mathrm{s}$ (Tabela 20). A oferta nesta área satisfaz completamente a demanda, com uma vazão excedente de $21,56 \mathrm{~m} 3 / \mathrm{s}$ (Tabela 21). Este fato deve-se a que nesta zona os rios orientais fornecem altas vazões de contribuição para a BBRCH (Figura 42). A contribuição subterrânea provém das nascentes e é mínima $(0,02$ $\mathrm{m}^{3} / \mathrm{s}$ ). Também pode haver uma contribuição da água subterrânea do El Altar, no entanto, neste trabalho esse aporte não foi estimado devido à dificuldade encontrada no campo no reconhecimento das nascentes. 
Tabela 20. Demanda mínima de água para irrigação na zona 2.

\begin{tabular}{llll}
\hline Cultura & Hectares & $\begin{array}{l}\text { Demanda } \\
\text { mínima } \\
\left(\mathrm{m}^{3} / \mathrm{s}\right)\end{array}$ & $\begin{array}{l}\text { Demanda } \\
\text { máxima } \\
\left(\mathrm{m}^{3} / \mathrm{s}\right)\end{array}$ \\
\hline Milho & 4940,41 & 1,57 & 2,51 \\
Batata & 1452,53 & 0,46 & 0,64 \\
Cereais & 356,4 & 0,10 & 0,15 \\
Vegetais & 356,4 & 0,37 & 0,53 \\
Frutais & 256,98 & 0,07 & 0,13 \\
Total & 7362,72 & 2,57 & 0,13 \\
\hline
\end{tabular}

Tabela 21. Demanda e oferta estimada para a zona 2.

\begin{tabular}{lcc}
\hline \multicolumn{1}{c}{ Uso outorga } & $\begin{array}{c}\text { Número } \\
\text { de } \\
\text { outorgas }\end{array}$ & $\begin{array}{c}\text { Demanda e } \\
\text { Oferta } \\
\left(\mathbf{m}^{\mathbf{3}} \mathbf{s} \mathbf{s}\right)\end{array}$ \\
\hline Irrigação estimada & & 2,57 \\
Doméstico & 201 & 1,80 \\
Dessedentação de animais & 124 & 0,018 \\
Cultivo peixe & 11 & 1,30 \\
Demanda Total & 336 & $\mathbf{5 , 6 8}$ \\
Oferta potencial superficial & & 21,56 \\
Oferta instalada subterrânea & & 0,02 \\
Oferta Total & & $\mathbf{2 1 , 5 8}$ \\
\hline
\end{tabular}

*Oferta instalada refere-se à vazão dos poços em funcionamento

Na zona 3 há menos demanda de água, uma vez que existem apenas 12 outorgas (Tabela 20). No entanto, a demanda mínima para irrigação de milho $\left(0,39 \mathrm{~m}^{3} / \mathrm{s}\right)$ apresenta o maior requerimento de água (Tabela 23). Note-se que o cultivo de peixes é a segunda demanda de água $\left(0,15 \mathrm{~m}^{3} / \mathrm{s}\right)$, o que representa $20,5 \%$ dos requerimentos da zona (Tabela 23 ). 


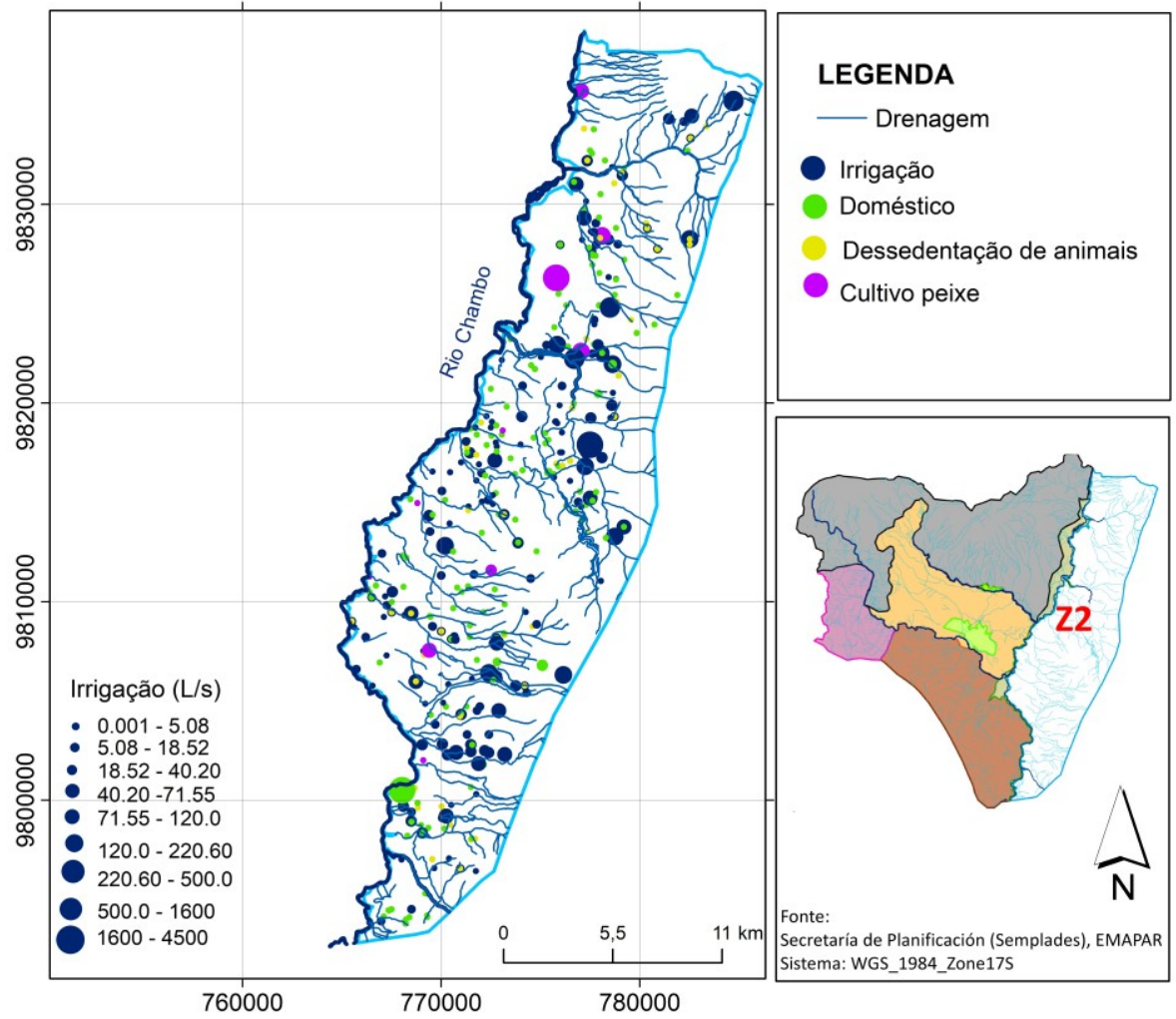

Figura 42. Demandas setoriais de água na zona 2, mostrando as outorgas com suas vazões e os diferentes usos.

Tabela 22. Demanda mínima de água para irrigação na zona 3.

\begin{tabular}{llll} 
Cultura & Hectares & $\begin{array}{c}\text { Demanda } \\
\text { mínima } \\
\left(\mathbf{m}^{3} / \mathbf{s}\right)\end{array}$ & $\begin{array}{c}\text { Demanda } \\
\text { máxima } \\
\left(\mathbf{m}^{3} / \mathbf{s}\right)\end{array}$ \\
\hline Milho & 1228,28 & 0,39 & 0,62 \\
Batata & 68,65 & 0,02 & 0,03 \\
Cereais & 0,49 & 0,0001 & 0,0002 \\
Vegetais & 446,79 & 0,10 & 0,14 \\
Frutais & 204,03 & 0,05 & 0,10 \\
Total & 1948,24 & 0,56 & 0,90 \\
\hline
\end{tabular}

A estimativa da oferta superficial corresponde a soma das vazões médias dos rios orientais e ocidentais que desaguam no rio Chambo (Tabela 23, Figura 43). 
Tabela 23. Demanda e oferta estimada para a zona 3.

\begin{tabular}{lcc}
\hline \multicolumn{1}{c}{ Uso outorga } & $\begin{array}{c}\text { Número } \\
\text { de } \\
\text { outorgas }\end{array}$ & $\begin{array}{c}\text { Demanda e } \\
\text { Oferta } \\
\left(\mathbf{m}^{3} / \mathbf{s}\right)\end{array}$ \\
\hline Irrigação estimada & 9 & 0,56 \\
Doméstico & 2 & 0,017 \\
Dessedentação de animais & 1 & 0,00063 \\
Cultivo de peixe & 12 & $\mathbf{0 , 7 2}$ \\
Demanda Total & & 37,24 \\
Oferta potencial superficial & & $\mathbf{3 7 , 2 4}$ \\
Oferta Total & & \\
\hline
\end{tabular}

*Oferta instalada refere-se à vazão dos poços em funcionamento

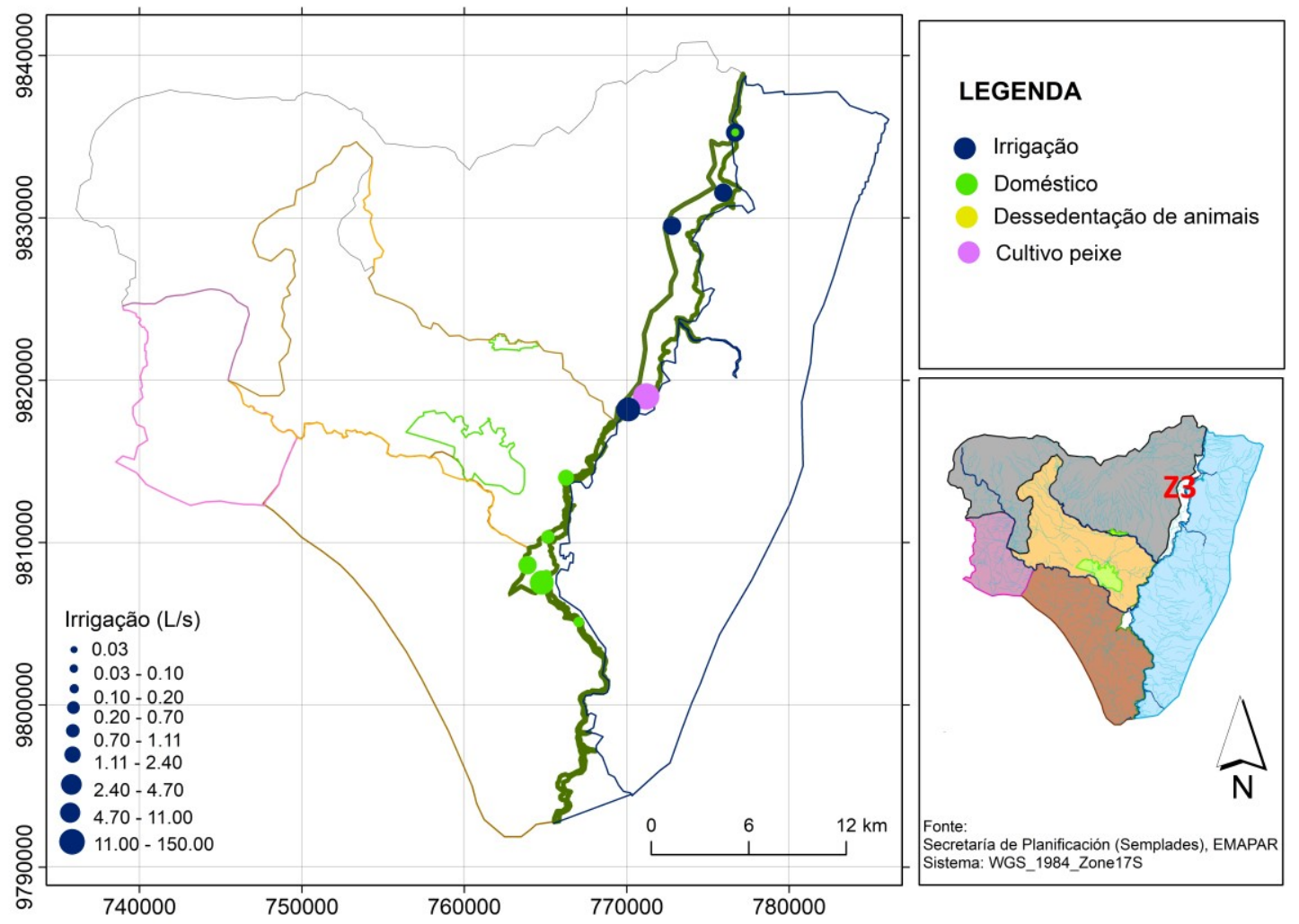

Figura 43. Demandas setoriais de água na zona 3, que mostra as outorgas com suas vazões e os diferentes usos.

A demanda total de água da zona 4 é de $4,97 \mathrm{~m}^{3} / \mathrm{s}$, as culturas de milho e vegetais são as que requerem as maiores vazões (Tabela 24). Dos outros usos 
a demanda doméstica é a maior, no entanto, representa apenas 2,8\% do requerimento de água na zona.

Tabela 24. Demanda mínima de água para irrigação na zona 4.

\begin{tabular}{llcc}
\hline Cultura & Hectares & $\begin{array}{c}\text { Demanda } \\
\text { mínima } \\
\left(\mathbf{m}^{3} \mathbf{s}\right)\end{array}$ & $\begin{array}{c}\text { Demanda } \\
\text { máxima } \\
\left(\mathbf{m}^{3} / \mathbf{s}\right)\end{array}$ \\
\hline Milho & 9730,39 & 3,09 & 4,94 \\
Batata & 479,74 & 0,15 & 0,21 \\
Cereais & 2270,48 & 0,65 & 0,94 \\
Vegetais & 2270,48 & 0,71 & 1,01 \\
Frutais & 733,18 & 0,19 & 0,37 \\
\hline
\end{tabular}

A oferta superficial é de $3,13 \mathrm{~m} / \mathrm{s}$ e considera as contribuições do sistema de drenagem e uma vazão segura de $40 \%$. As ofertas subterrâneas instaladas foram estimadas somando-se as vazões de 7 das 11 nascentes que são aproveitadas nesta zona (Tabela 25, Figura 44). Apesar do fato de que nesta zona estão localizados os principais poços e nascentes da $\mathrm{BBRCH}$, as vazões destes são consideradas nas estimativas de oferta da zona 7 , uma vez que essas vazões são consumidas nessa zona. É evidente que existe um déficit de água nesta zona $\left(1,57 \mathrm{~m}^{3} / \mathrm{s}\right)$.

Tabela 25. Demanda e oferta estimada para a zona 4.

\begin{tabular}{lcc}
\hline \multicolumn{1}{c}{ Uso outorga } & $\begin{array}{c}\text { Número } \\
\text { de } \\
\text { outorgas }\end{array}$ & $\begin{array}{c}\text { Demanda e } \\
\text { Oferta } \\
\left(\mathbf{m}^{3} / \mathbf{s}\right)\end{array}$ \\
\hline Irrigação estimada & 96 & 4,78 \\
Doméstico & 30 & 0,14 \\
Dessedentação de animais & 10 & 0,0056 \\
Cultivo de peixe & 136 & $\mathbf{4 , 9 7}$ \\
Demanda Total & & 3,13 \\
Oferta potencial superficial & & 0,27 \\
*Oferta instalada subterrânea & & $\mathbf{3 , 4}$ \\
Oferta Total & & \\
\hline
\end{tabular}

*Oferta instalada refere-se à vazão dos poços em funcionamento 


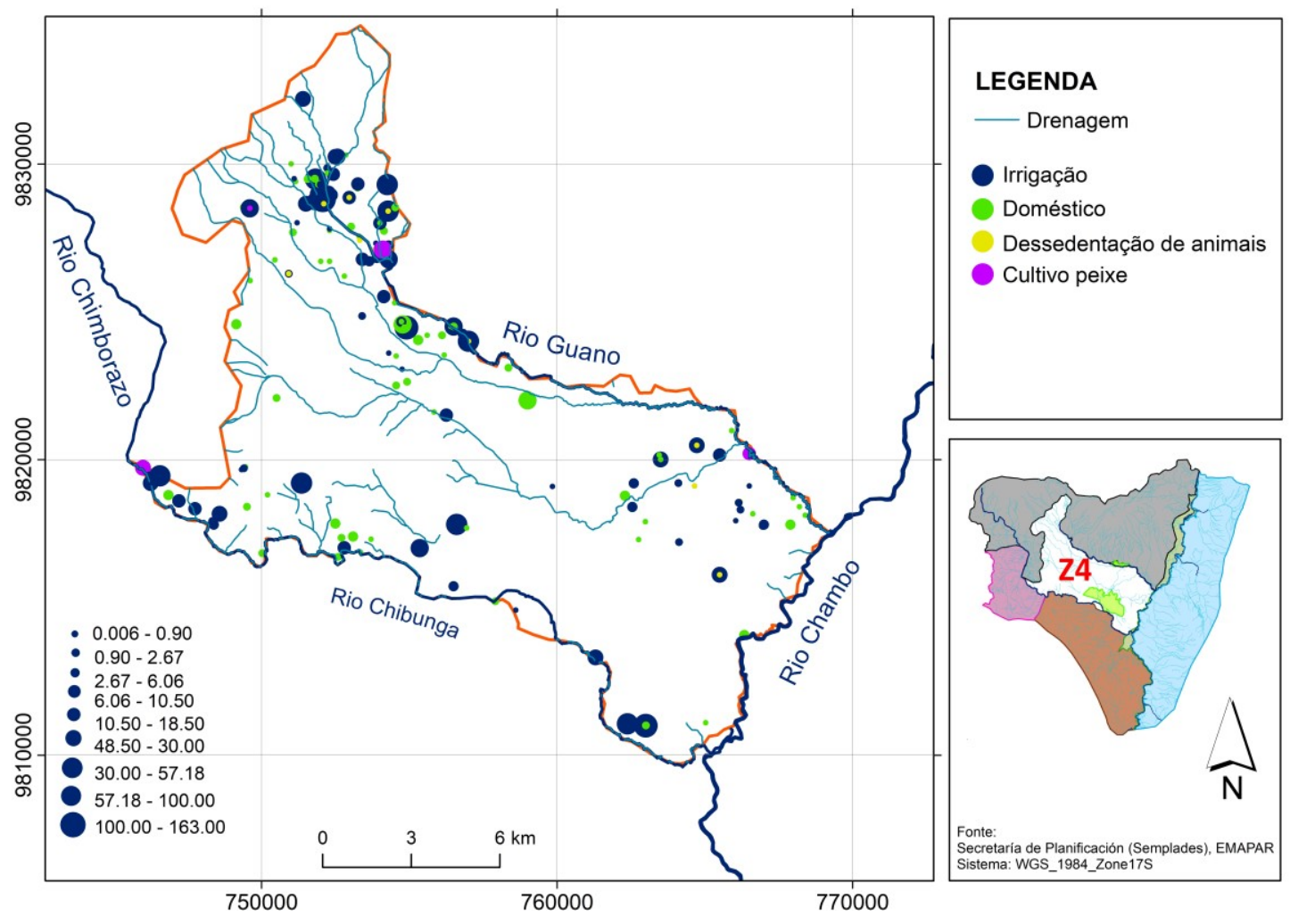

Figura 44. Demandas setoriais de água na zona 4, mostrando as outorgas com suas vazões e os diferentes usos.

Na zona 5, a maior demanda de água é para irrigação e, principalmente, a cultura de milho (Tabela 26) seguida da demanda doméstica e dessedentação de animais (Tabela 27).

Tabela 26. Demanda mínima de água para irrigação na zona 5.

\begin{tabular}{|c|c|c|c|}
\hline Cultura & Hectares & $\begin{array}{c}\text { Demanda } \\
\text { mínima } \\
\left(\mathrm{m}^{3} / \mathrm{s}\right)\end{array}$ & $\begin{array}{c}\text { Demanda } \\
\text { máxima } \\
\left(\mathrm{m}^{3} / \mathrm{s}\right)\end{array}$ \\
\hline Milho & 2403,4 & 0,76 & 1,22 \\
\hline Batata & 36,05 & 0,01 & 0,02 \\
\hline Cereais & 585,56 & 0,17 & 0,24 \\
\hline Total & 3025,01 & 0,94 & 1,48 \\
\hline
\end{tabular}

Nessa zona a demanda total de água excede à oferta em $0,64 \mathrm{~m}^{3} / \mathrm{s}$. Para a oferta foi estimada a contribuição superficial do rio Chimborazo (Figura 45). As 
ofertas subterrâneas não puderam ser estimadas devido à dificuldade do acesso para as nascentes cadastradas nos registros da SENAGUA.

Tabela 27.Demanda e oferta estimada para a zona 5.

\begin{tabular}{lcc}
\hline \multicolumn{1}{c}{ Uso outorga } & $\begin{array}{c}\text { Número } \\
\text { de } \\
\text { outorgas }\end{array}$ & $\begin{array}{c}\text { Demanda e } \\
\text { Oferta } \\
\left(\mathbf{m}^{3} / \mathbf{s}\right)\end{array}$ \\
\hline Irrigação estimada & 48 & 0,94 \\
Doméstico & 26 & 0,027 \\
Dessedentação de animais & 74 & $\mathbf{0 , 0 0 1 9}$ \\
Demanda Total & & 0,32 \\
Oferta potencial superficial & & $\mathbf{0 , 3 2}$ \\
Oferta Total & & \\
\hline
\end{tabular}
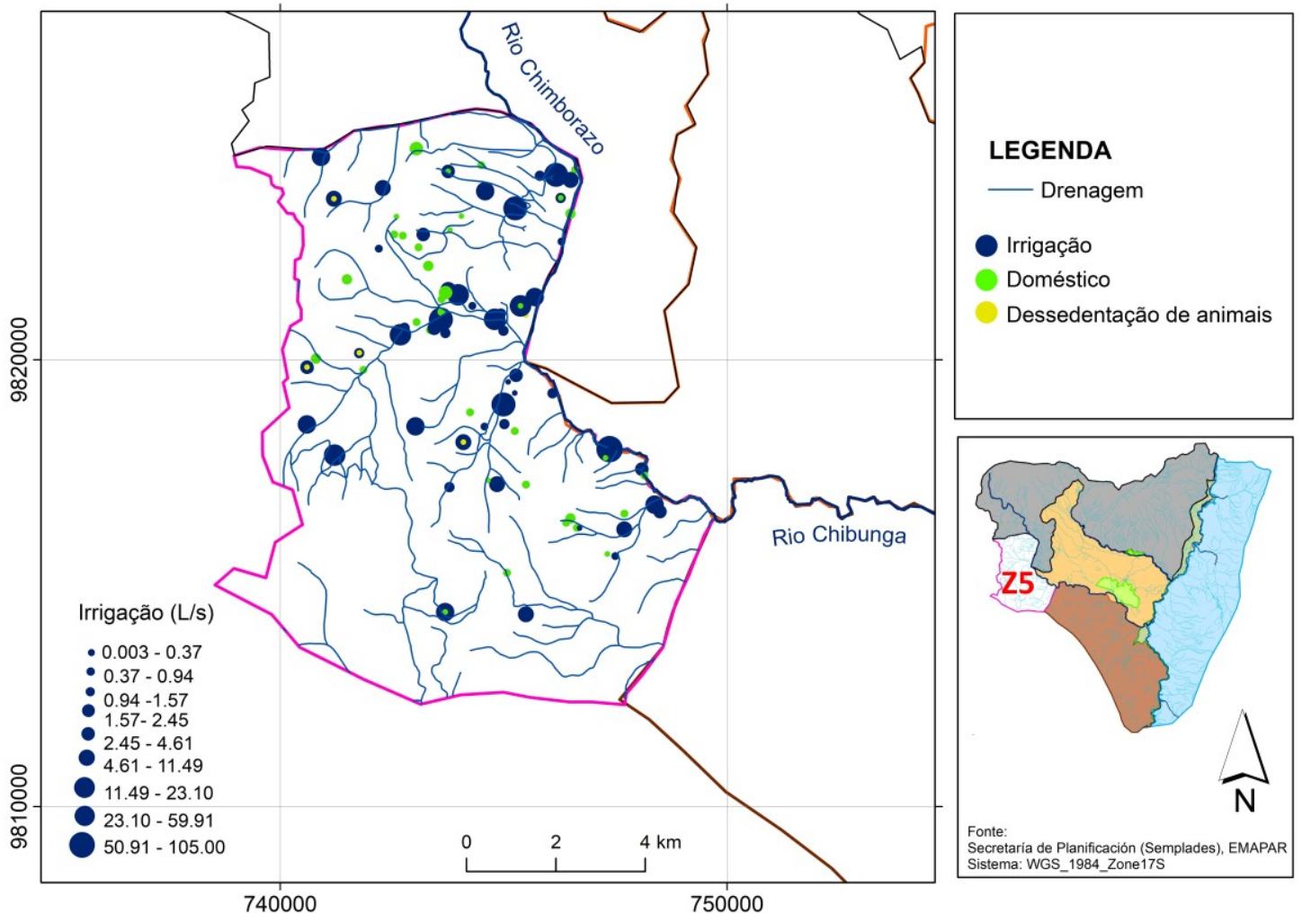

Figura 45. Demandas setoriais de água na zona 5, mostrando as outorgas com suas vazões e os diferentes usos. 
As zonas 6 e 7 correspondem às áreas urbanas de Riobamba e Guano, respectivamente, e ocupam aproximadamente 1780 hectares $(1,2 \%)$ da área total da bacia (Figura 46). Nestas zonas foram estimadas as demandas domésticas e suas projeções até o ano de 2040 (seção 5.7.1).

Tabela 28. Demanda e oferta estimada para a zona 6.

\begin{tabular}{lc}
\hline \multicolumn{1}{c}{ Uso outorga } & $\begin{array}{c}\text { Demanda } \mathbf{~} \\
\text { Oferta }\left(\mathbf{m}^{3} / \mathbf{s}\right)\end{array}$ \\
\hline Doméstico & 0,56 \\
Demanda Total & $\mathbf{0 , 5 6}$ \\
Oferta instalada subterrânea & \\
Poços Llío & 0,35 \\
Nascente San Pablo & 0,24 \\
Soma Llío+San Pablo & 0,59 \\
*Menos 15\% & 0,50 \\
Poços Riobamba & 0,18 \\
Oferta Total & $\mathbf{0 , 6 8}$
\end{tabular}

*15\% de vazão instalada devido ao acordo realizado entre as cidades de Riobamba e Guano. 0 acordo afirma que a EP-EMAPAR pode extrair e transportar água dos poços perfurados em Guano somente se alocar $15 \%$ do extraído para a cidade de Guano.

As ofertas instaladas provêm essencialmente de recursos hídricos subterrâneos explorados pelos poços e as nascentes localizados na própria cidade e no município de Guano. Cerca de $67 \%$ dos poços são operados pela EP-EMAPAR e os 33\% restantes são privados. Os poços e nascentes mais produtivos estão localizados na zona 4 (Llío), enquanto os poços com menores vazões estão localizados na zona 7, no município de Riobamba (Tabela 28, Figura 46). Existe também uma nascente (San Pablo) que está sendo aproveitada para o abastecimento doméstico de Riobamba e Guano. Essa nascente tem a maior vazão da BBRCH $\left(0,24 \mathrm{~m}^{3} / \mathrm{s}\right)$ e a sua exploração é feita pela EP-EMAPAR.

As quatro nascentes localizadas nas margens do rio Guano e Chibunga estão sendo aproveitadas pelas atividades de comércio (por exemplo: lavagem de roupas). 

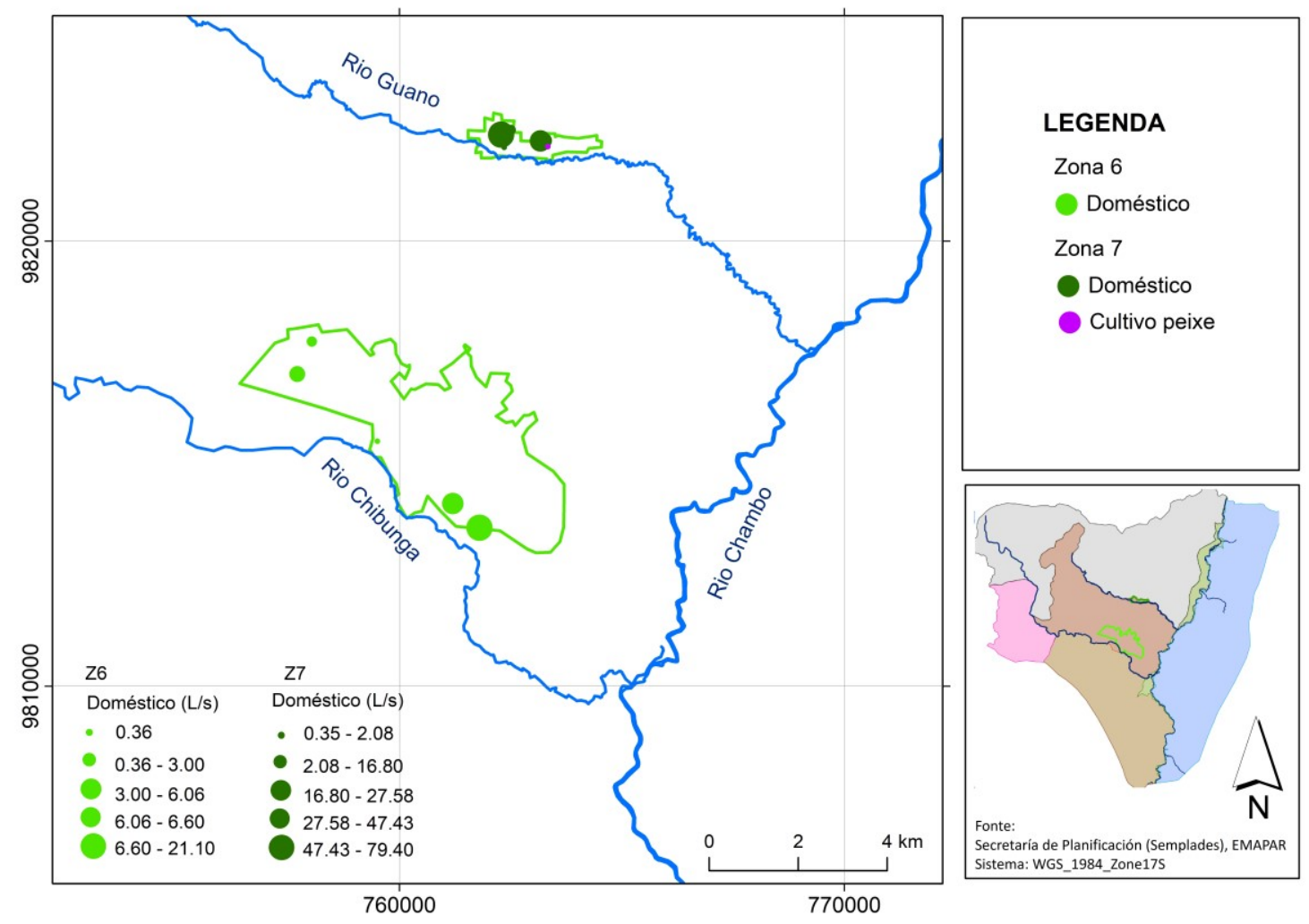

Figura 46. Demandas setoriais de água nas zonas 6 e 7.

Ao comparar-se as demandas domésticas máximas (210 $\left.\mathrm{m}^{3} / \mathrm{hab} / \mathrm{dia}\right)$, médias (155 m³/hab/dia) e mínimas (100 m³/hab/dia), com a oferta hídrica da zona 6, fica claro que nas condições atuais a oferta satisfaz a demanda mínima de água (100 m³/hab/dia) (Figura 47). A demanda média (155 m³/hab/dia) estará comprometida a partir do ano 2025 e a máxima já apresenta déficit desde 2015. Para chegar nestas conclusões foram assumidas ofertas constantes e bombeamentos dos poços de 24 horas. 


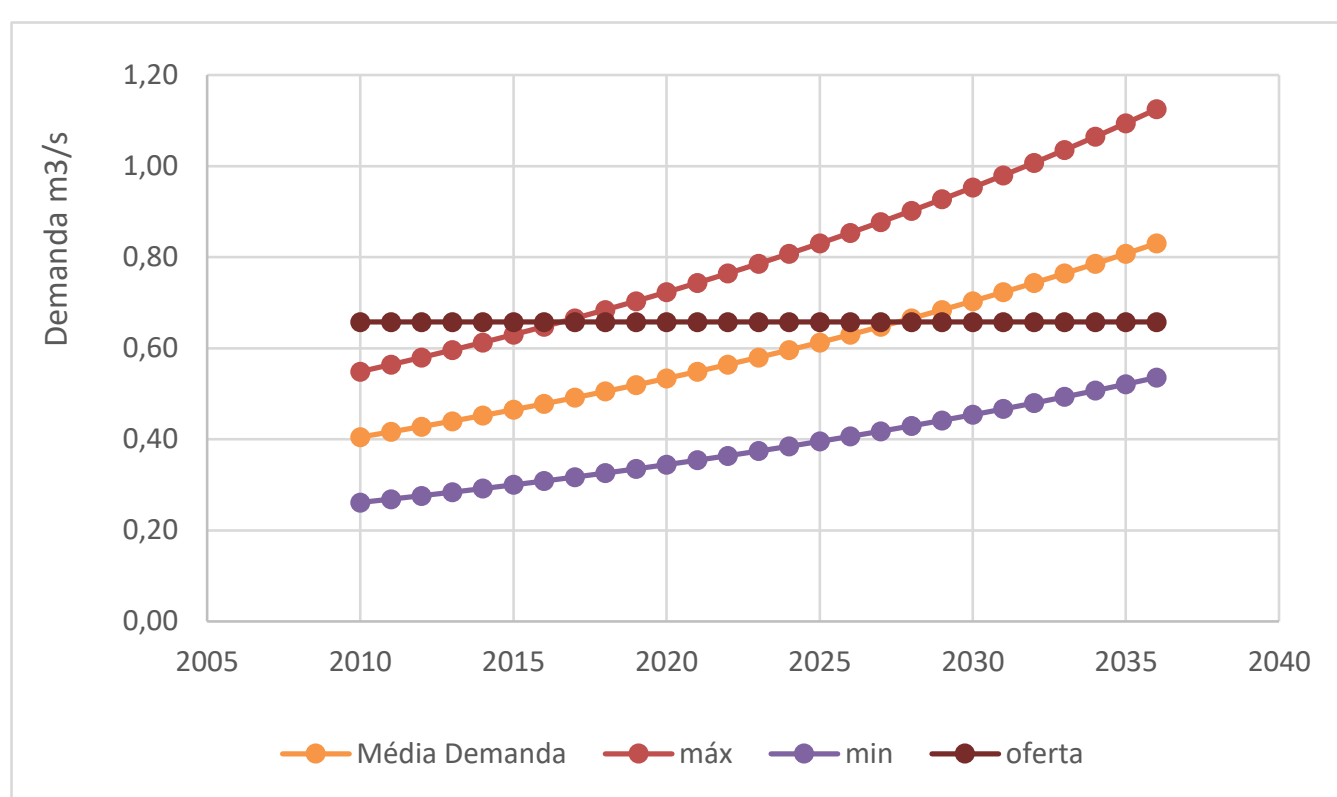

Figura 47. Demandas e ofertas domésticas em Riobamba, considerando as projeções populacionais até 2040. Demandas mínimas, médias e máximas requeridas para o uso doméstico.

A zona 7 registra a mais baixa demanda de água da BBRCH (Tabela 29). A oferta de água supera a demanda em $0,58 \mathrm{~m} 3 / \mathrm{s}$. A maior oferta de água subterrânea provém dos poços de Llío e a nascente de San Pablo (15\% da sua produção).

Tabela 29.Demanda e oferta estimada para a zona 7.

\begin{tabular}{lc}
\hline \multicolumn{1}{c}{ Uso outorga } & $\begin{array}{c}\text { Demanda } \\
\text { e Oferta } \\
\left(\mathbf{m}^{3} / \mathbf{s}\right)\end{array}$ \\
\hline Doméstico & 0,079 \\
Cultivo de peixe & 0,00035 \\
Demanda Total & $\mathbf{0 , 0 7 9}$ \\
Oferta instalada subterrânea \\
Poços Llío & 0,35 \\
Nascente San Pablo & 0,24 \\
Soma Llío+San Pablo & 0,59 \\
*15\% Guano & 0,08 \\
Poços Guano & 0,005 \\
Oferta Total & $\mathbf{0 , 0 8 5}$
\end{tabular}


Como foi analisado na zona 6 , na zona 7 observa-se que nas condições atuais a oferta satisfaz a demanda mínima e média de água. A demanda máxima estaria comprometida a partir do ano de 2020 (Figura 48).

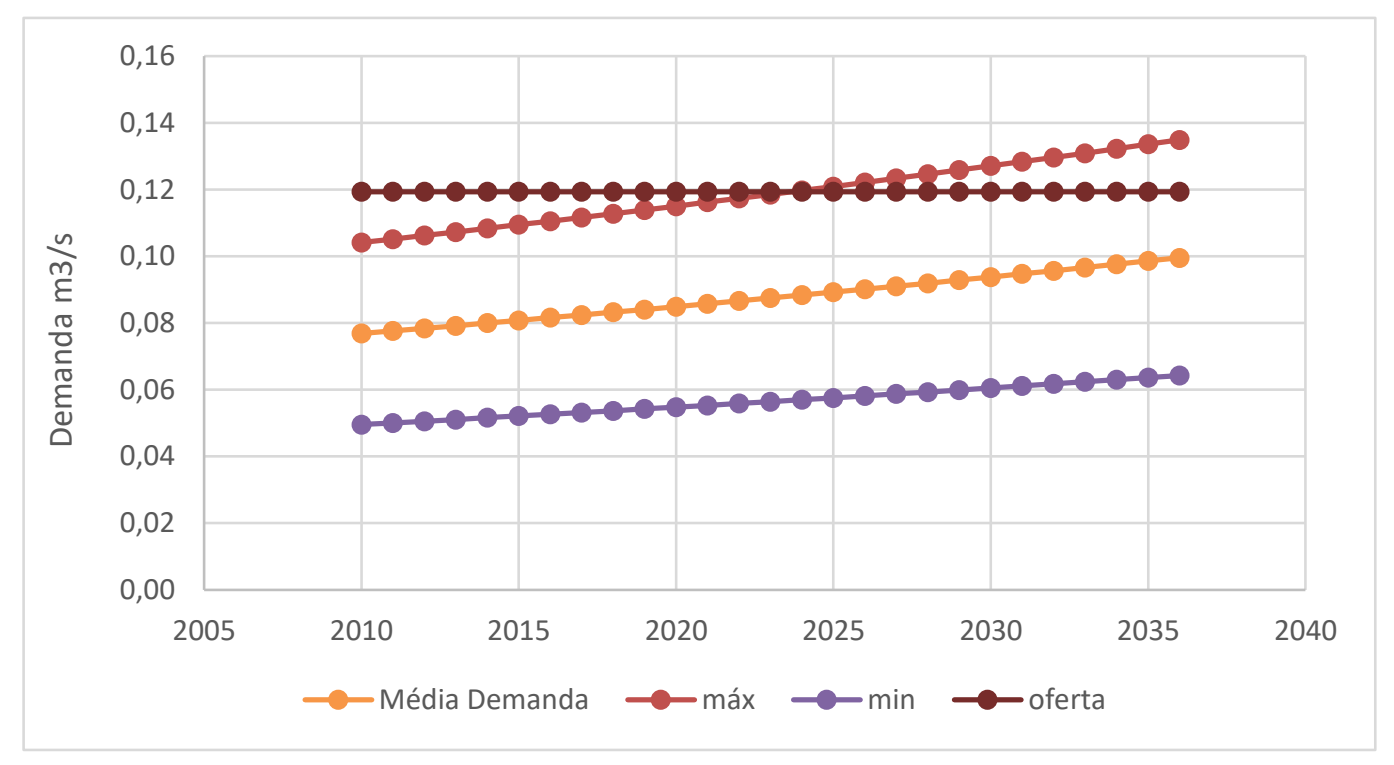

Figura 48. Demandas e ofertas domésticas em Guano, considerando as projeções populacionais até 2040. Demandas mínimas, médias e máximas requeridas para o uso doméstico.

A zona 8 contém a maior área cultivada da $\mathrm{BBRCH}(11,30 \%)$. A maior demanda estimada é para a cultura de milho e cereais $\left(4,51 \mathrm{~m}^{3} / \mathrm{s}\right)$ (Tabela 30 , Figura 49).

Tabela 30.Demanda mínima de água para irrigação na zona 8.

\begin{tabular}{lccc}
\hline Cultura & Hectares & $\begin{array}{c}\text { Demanda } \\
\text { mínima } \\
\left(\mathbf{m}^{3} / \mathbf{s}\right)\end{array}$ & $\begin{array}{c}\text { Demanda } \\
\text { máxima } \\
\left(\mathbf{m}^{3} / \mathbf{s}\right)\end{array}$ \\
\hline Milho & 8262,28 & 2,62 & 4,19 \\
Batata & 494,44 & 0,16 & 0,22 \\
Cereais & 6637,26 & 1,89 & 2,74 \\
Vegetais & 1330,56 & 0,30 & 0,42 \\
Frutais & 24,19 & 0,01 & 0,01 \\
Total & 16748,73 & 4,97 & 7,58 \\
\hline
\end{tabular}


A Tabela 31 mostra que há um déficit hídrico na zona (o maior déficit estimado na área de estudo), a oferta $\left(2,17 \mathrm{~m}^{3} / \mathrm{s}\right)$ não satisfaz a demanda hídrica $\left(5,15 \mathrm{~m}^{3} / \mathrm{s}\right)$.

Tabela 31. Demanda e oferta estimada para a zona 8.

\begin{tabular}{lcc}
\hline \multicolumn{1}{c}{ Uso outorga } & $\begin{array}{c}\text { No. } \\
\text { outorgas }\end{array}$ & $\begin{array}{c}\text { Demanda } \\
\left(\mathbf{m}^{\mathbf{3}} \mathbf{s} \mathbf{s}\right)\end{array}$ \\
\hline Irrigação estimada & 201 & 4,97 \\
Doméstico & 28 & 0,15 \\
Dessedentação de animais & 1 & 0,0048 \\
Cultivo de peixe & 230 & $\mathbf{5 , 1 5}$ \\
Demanda Total & & 2,17 \\
Oferta potencial superficial & & $\mathbf{2 , 1 7}$ \\
Oferta Total & & \\
\hline
\end{tabular}
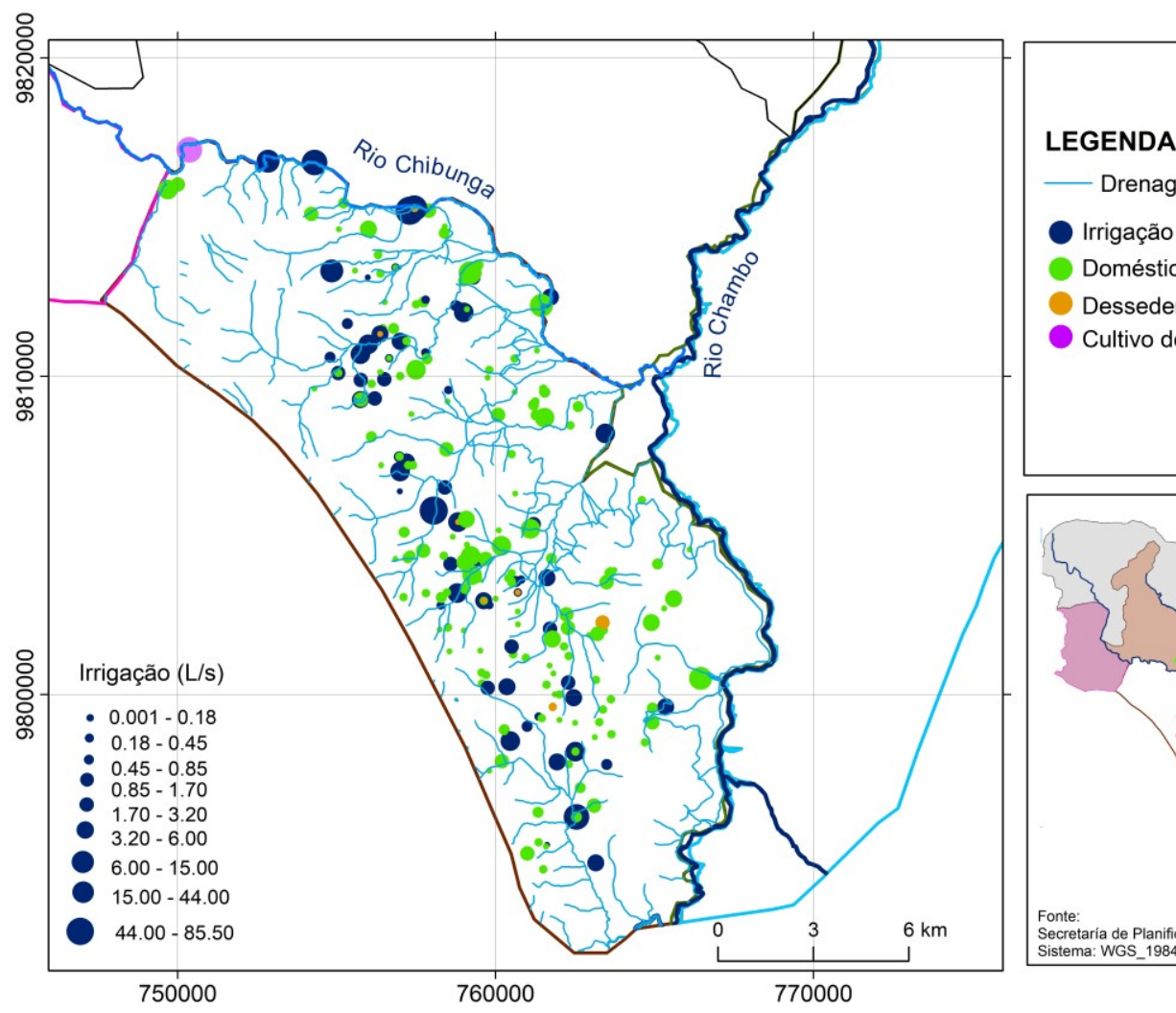

Drenagem

Irrigação

Doméstico

Dessedentação de animais

Cultivo de peixe

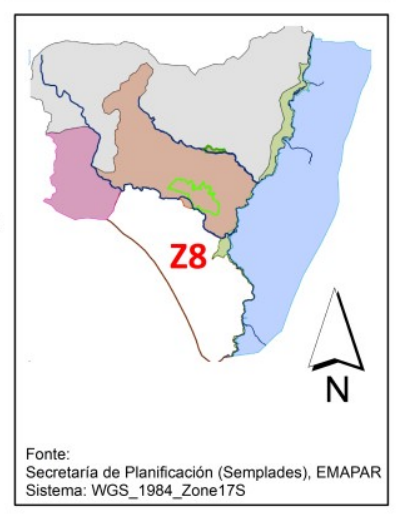

Figura 49. Demandas setoriais de água na zona 8. 
Com estas estimativas foi realizada uma análise comparativa entre zonas com similares condições de uso e ocupação de solo e suas demandas e ofertas de água. Observou-se que das oito zonas, seis (Z1, Z2, Z3, Z4, Z5 e Z8) correspondem, principalmente, a áreas agrícolas, sendo a cultura de milho a que requer mais água, uma vez que tem a maior área de cultivo. A zona 8 é a que demanda maior quantidade de água para irrigação, a zona 7 para uso doméstico e a zona 1 para a indústria do cimento (Tabela 32 ).

A maior contribuição das águas superficiais corresponde às zonas Z2 e Z3, enquanto que a menor corresponde às zonas 6 e 7, representadas pelas áreas urbanas de Riobamba e Guano (Tabela 32).

Tabela 32. Oferta potencial de água superficial e oferta instalada subterrânea, devido à recarga local nas zonas definidas na $\mathrm{BBRCH}$.

\begin{tabular}{ccc}
\hline Zonas & \multicolumn{2}{c}{ Vazão } \\
& $\begin{array}{c}\text { Potencial } \\
\text { superficial } \\
\left(\mathbf{m}^{3} / \mathbf{s}\right)\end{array}$ & $\begin{array}{c}\text { Instalada } \\
\text { subterrânea } \\
\left(\mathbf{m}^{3} \mathbf{s} \mathbf{s}\right)\end{array}$ \\
\hline Z1 & 1,40 & \\
Z2 & 21,56 & 0,02 \\
Z3 & 37,24 & - \\
Z4 & 3,13 & 0,27 \\
Z5 & 0,32 & - \\
Z6 & - & 0,68 \\
Z7 & - & 0,085 \\
Z8 & 2,17 & - \\
\hline
\end{tabular}

As estimativas até agora calculadas para a disponibilidade potencial superficial assumem que os fluxos do rio são sustentados ou mantidos somente pela água superficial (escoamento). Mas os rios também podem ter como contribuição as águas subterrâneas (contribuição que não foi calculada neste trabalho, devido à falta de informação). No entanto, assumindo $40 \%$ do fluxo de base do rio, uma certa contribuição das águas subterrâneas seria excluída. É necessário obter uma série temporal de medições de vazão nos rios Guano, Chimborazo e Chibunga, principalmente para determinar o cálculo do fluxo de base dos rios. Assim também é necessário avaliar detalhadamente cada trecho dos rios, fazer um levantamento detalhado das nascentes localizadas em cada 
trecho, caracterizá-las e determinar suas vazões ao longo do tempo, para compará-las com as vazões dos rios nos períodos de inverno e verão.

\subsubsection{Problemas relevantes na gestão de recursos hídricos na $B B R C H$}

$\mathrm{Na}$ área de estudo destacam-se, no amplo contexto social, econômico e ambiental os seguintes problemas:

Na zona 1: as atividades econômicas relacionadas à agricultura com predominância para as culturas de milho dependem da água proveniente do degelo do Chimborazo e seu páramo, porque a precipitação local é muito baixa. $\mathrm{O}$ derretimento das geleiras (Chimborazo e El altar) pelos efeitos de mudanças climáticas afetaria grandemente à $\mathrm{BBRCH}$, uma vez que o suprimento hídrico superficial e subterrâneo está baseado essencialmente nessas fontes.

Na zona 2: na parte baixa (cota 2800 m.s.n.m), prevalecem as atividades agrícolas com seu principal aqueduto para irrigação (Quimiag), que fornece água para 1800 famílias (Senplades, 2012). Nesta zona, nos rios Blanco, Alao e Ulpán existem pequenas hidrelétricas, que geram eletricidade para a Empresa Elétrica Riobamba S.A (EERSA). Isto gera um problema na alocação de recursos hídricos entre os usuários, já que irrigantes acreditam que as vazões superficiais estão afetadas pela presença dessas hidrelétricas (que geram eletricidade, principalmente, para a cidade de Riobamba) desfavorecendo as vazões para irrigação $\left(2,57 \mathrm{~m}^{3} / \mathrm{s}\right)$.

Nas zonas urbanas Z6 e Z7: o crescimento da população (população rural que migra para Riobamba e Guano) incrementa a demanda de água para abastecimento doméstico e amplia a descarga de efluentes não tratados para os rios Guano e Chibunga. Segundo estimativas da EP-EMAPAR (2017), existem perdas na rede de abastecimento e distribuição de água, assim como fugas na rede de esgoto em até $30 \%$.

$\mathrm{Na}$ zona 7: existia um conflito de jurisdição, posto que as águas subterrâneas localizadas no município de Guano (que compreende os povoados de Llío e San Pablo) são distribuídas principalmente para a cidade de Riobamba, que conta com 8 poços para completar seu sistema de abastecimento de água (Figura 50). Esta questão foi discutida entre as autoridades locais dos municípios, que chegaram a um acordo no qual o município de Riobamba, 
representado pela EP-EMAPAR, e que é responsável pela distribuição de água pode usar $90-85 \%$ deixando o restante para Guano (EP-EMAPAR, conversação pessoal, 2017). Este tópico é tratado com sigilo e reserva e há nova rodada de negociação a cada quatro anos. No entanto, a população rural do município de Guano, conhece esse assunto e constantemente reivindica a captação de águas subterrâneas feitas pela EP-EMAPAR. Eles acreditam que a água que a EPEMAPAR distribui para o fornecimento doméstico em Riobamba poderia ser distribuída para irrigação nas áreas rurais de Guano. Eles também afirmam que as ditas captações da EP-EMAPAR diminuem o nível de água do rio Guano e seus afluentes. De modo que qualquer trabalho de campo, medição de níveis e vazões no rio Guano são interrompidos constantemente pelos moradores da área rural de Guano. 


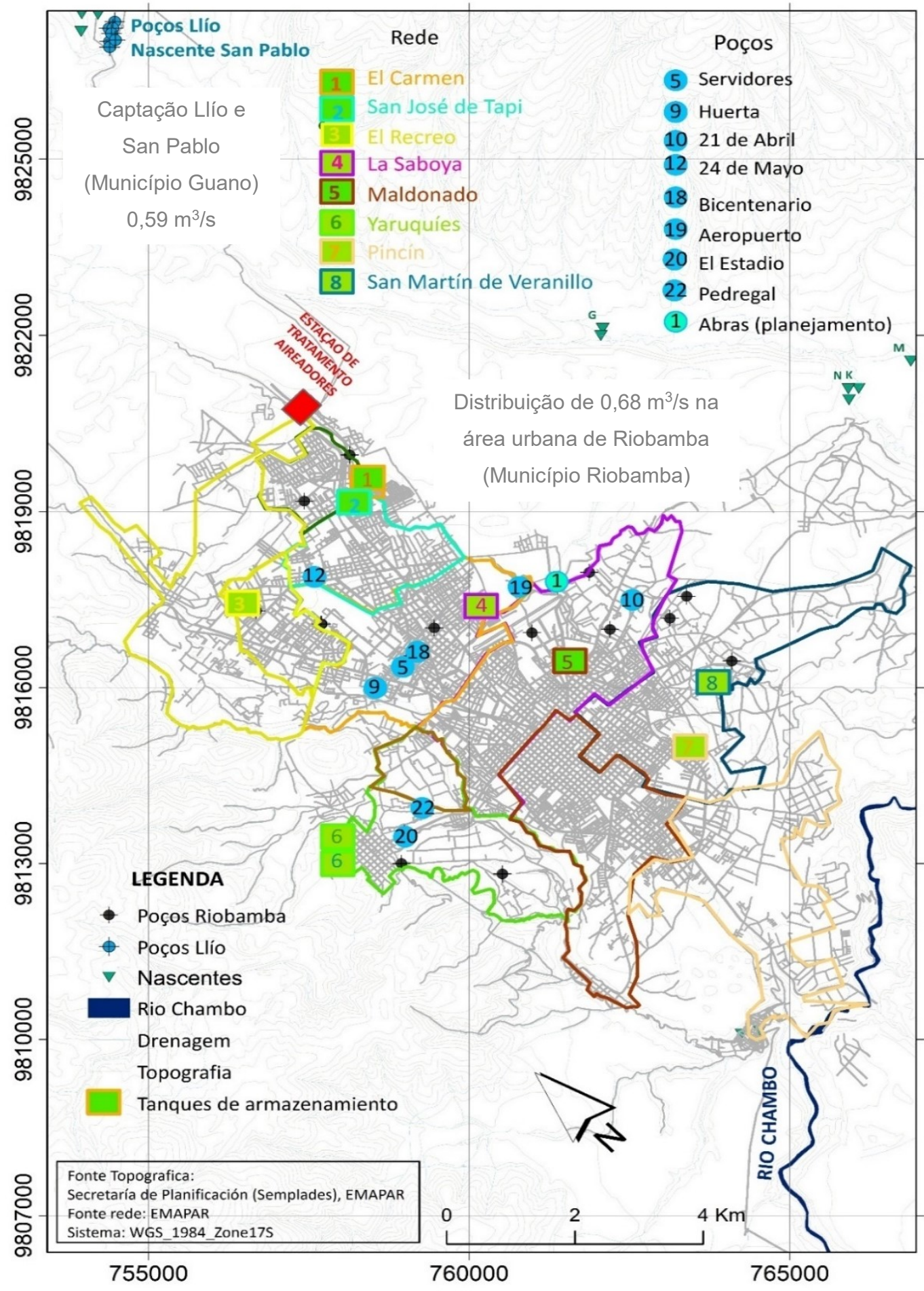

Figura 50. Captação de água subterrânea através de 8 poços e uma nascente localizados nas localidades de Llío e San Pablo, respectivamente (município de Guano). 7 poços na cidade de Riobamba e 1 poço em Yaruquíes (município de Riobamba) para abastecimento doméstico de $70 \%$ da população do município. Sistema de captação e alocação operado pela EP-EMAPAR (EP-EMAPAR, 2017). 


\section{DISCUSSÃO}

\subsection{Sobre o modelo conceitual na BBRCH}

Neste trabalho propõe-se um modelo conceitual baseado nos dados de geologia, hidrologia e hidroquímica, obtidos em campo e da literatura, e concluiuse que todas estas contribuições superficiais e subterrâneas descarregam no rio Chambo. Neste modelo foi também estimada a oferta potencial superficial, assim como a oferta instalada subterrânea disponível na área de estudo, como apresentado nas seções 6.7 e 6.9 .

O fluxo subterrâneo ocorre da zona de recarga lateral do Chimborazo e Igualata (cordilheira ocidental) e do Tungurahua e El Altar (Cordilheira Oriental) até a zona de descarga no rio Chambo. Existem também descargas das zonas sudoeste (Z5) e sudeste (Z8) provenientes, principalmente, das precipitações locais.

Os resultados das análises hidroquímicas das águas dos poços $\mathrm{e}$ nascentes mostraram três tipos de águas na $\mathrm{BBRCH}$. A tabela 12 mostra que as águas provenientes das nascentes de Cubijíes são quimicamente diferentes daquelas que provêm do Aquífero Llío-Guano, Riobamba e Yaruquíes. Note-se a importante diferença nos parâmetros físicos de condutividade elétrica, $\mathrm{pH}$ e temperatura, assim como nas concentrações dos ânions sulfato $\left(\mathrm{SO}_{4}^{-2}\right)$, carbonatos $\left(\mathrm{CO}_{3}^{-}\right)$e bicarbonatos $\left(\mathrm{HCO}_{3}^{-}\right)$e dos cátions Sódio $(\mathrm{Na}+)$ e Magnésio $(\mathrm{Mg}+)$. As concentrações das nascentes de Cubijíes (as mais afastadas do Chimborazo) apresentam valores de sulfato cerca de 20 vezes maiores que as concentrações das águas da nascente de San Pablo e das águas dos poços de Llío e Guano. Isto evidencia águas de diferente origem, sendo que as águas das nascentes de Cubijíes provêm de maiores profundidades

Embora tenham-se obtido resultados de assinaturas isotópicas $\left(\delta^{18} \mathrm{O}\right.$ e $\left.\delta^{2} \mathrm{H}\right)$ de poucas amostras (17 amostras no total), há evidências de que as águas coletadas no Aquífero Llío-Guano (6 amostras: 3 poços e 3 nascentes) e no Aquífero Riobamba (5 amostras: 4 poços e 1 nascente) têm a mesma assinatura isotópica, ou seja, similarmente empobrecidas em $\delta^{18} \mathrm{O}$ e $\delta^{2} \mathrm{H}$, tendo uma diferença de altitude de quase $400 \mathrm{~m}$ entre elas, o que confirmaria que a fonte 
dessas águas provêm da recarga do Chimborazo, como é mostrado na seção 6.6.1. Além disso encontrou-se uma diferença nas assinaturas isotópicas das amostras dos aquífero Llío-Guano e Riobamba com as amostras do Aquífero Yaruquíes e as nascentes de Cubijíes, o que mostraria águas de diferentes origens, sendo o Chimborazo a fonte das águas do Aquífero Llío-Guano e Riobamba, enquanto que o El Altar seria a fonte das águas das nascentes de Cubijíes.

No caso da assinatura isotópica da amostra proveniente do poço 4 (Aquífero de Riobamba), evidencia-se uma similaridade com a assinatura das nascentes de Cubijíes, o que mostraria uma fonte similar e/ou influência da recarga local. A diferença entre as assinaturas dos poços do Aquífero de Riobamba (poço 19 e poços 11 e 13) pode ser explicada devido a que o poço 19 estaria captando água da recarga local da zona 8.

Os resultados das análises químicas e isotópicas das águas do Aquífero Llío-Guano, quando comparados com as águas do Aquífero Yaruquíes e das nascentes de Cubijíes, evidenciam origens distintas. As altas concentrações de sódio e sulfato nas águas de Yaruquíes e Cubijíes poderiam supor uma origem vulcânica, provavelmente águas provenientes do vulcão El Altar, como mostrado na seção 6.6. Para validar esse fato, estas águas precisam ser profundas e conduzidas pelas fraturas.

Estudos isotópicos no Equador, no Aquífero Chiche e llaló (na província de Pichincha) evidenciaram águas similarmente enriquecidas em $\delta^{18} \mathrm{O}$ e $\delta^{2} \mathrm{H}$ (Manciati, 2014). Na ocasião, as águas subterrâneas foram interpretadas como águas que sofreram troca de isótopos na relação água-rocha magmática, processo que envolveu resfriamento da água com a perda da sua fase de vapor. O vapor poderia ter escapado pelas fraturas presentes nas formações geológicas (Manciati, 2014).

\subsection{Contribuições para o planejamento integrado de recursos hídricos}

O planejamento integrado de recursos hídricos requer um conjunto mínimo de estudos e propostas técnicas (uma base de dados e informações socialmente acessíveis, controle dos impactos sobre os sistemas hídricos) e negociações 
políticas (definição dos direitos de uso, a cobrança pelo uso de recursos hídricos) para atender às demandas e às expectativas dos usuários de recursos hídricos e para evitar a geração de conflitos entre eles. Diante disso, uma estratégia para o planejamento integral de recursos hídricos deve avaliar: i) as atividades realizadas em cada uma das zonas e sua evolução no futuro; ii) as tendências em relação à ameaça da qualidade ambiental, como por exemplo o crescimento urbano; iii) a preservação da oferta hídrica e a otimização da sua utilização; e iv) a consideração da disponibilidade do recurso a jusante e a montante dos novos projetos hidráulicos (transposição de água superficial desde outras bacias) e dos aquedutos realizados para a captação de água potável e para a agricultura.

A estimativa das ofertas (potenciais superficiais $e$ instalações subterrâneas) e das demandas de água em cada zona, pode fornecer uma visão geral qualitativa da vulnerabilidade de cada uma delas, em relação ao excedente ou déficit do recurso hídrico. A Tabela 33 mostra um resumo dos resultados acima descritos (seção 6.8.1). A quinta coluna corresponde à porcentagem de excedente ou déficit com respeito à demanda estimada, calculada como:

$$
n=\frac{\text { oferta-demanda }}{\text { demanda }} \times 100
$$

Isto permite identificar na BBRCH zonas de vulnerabilidade alta $(\mathrm{n}<0)$, média $(0<n<100 \%)$ e baixa $(n>100 \%)$. A Tabela 33 mostra que as zonas Z4, Z5 e Z8 têm vulnerabilidade alta, as zonas Z1, Z6 e Z7 apresentam vulnerabilidade média e as zonas Z2 e Z3 vulnerabilidade baixa. A Z3 é a descarga da bacia no rio Chambo e acumula todas as vazões superficiais das outras zonas. Estas conclusões também são ilustradas na Figura 51, que mostra as diferentes zonas definidas neste trabalho com uma cor associada à sua vulnerabilidade (vermelho: alta, amarelo: média e verde: baixa). Os círculos representam as outorgas, a cor de cada círculo está associada ao uso para o qual cada outorga foi concedida e o tamanho é proporcional à vazão outorgada, $\mathrm{em} \mathrm{m} / \mathrm{s}$. É claro que a maioria das outorgas acompanham o percurso dos rios, assim como na Z4, Z5 e Z8 (maior vulnerabilidade) possuem uma maior quantidade de outorgas para irrigação. A Z2 (baixa vulnerabilidade) possui, 
também, uma grande quantidade de outorgas, mas a alta vazão disponível nesta zona faz com que não apresente problemas de abastecimento do recurso.

Tabela 33.Ofertas e demandas e \% do excedente hídrico para as 8 zonas.

\begin{tabular}{|c|c|c|c|c|}
\hline Zonas & $\begin{array}{c}\text { Demanda } \\
\left(\mathrm{m}^{3} / \mathrm{s}\right)\end{array}$ & $\begin{array}{c}\text { Oferta } \\
\text { Total } \\
\left(\mathrm{m}^{3} / \mathrm{s}\right)\end{array}$ & $\begin{array}{c}\text { Oferta } \\
\text { Total- } \\
\text { Demanda } \\
\text { Total }\end{array}$ & $\begin{array}{c}\mathrm{n}=\% \text { do } \\
\text { Excedente } \\
\text { (déficit) com } \\
\text { respeito à } \\
\text { demanda }\end{array}$ \\
\hline Z1 & 3,41 & 4,84 & 1,43 & 41,94 \\
\hline Z2 & 5,68 & 21,58 & 15,9 & 279,93 \\
\hline Z3 & 0,72 & 37,24 & 36,52 & 5072,22 \\
\hline Z4 & 4,97 & 3,4 & $-1,57$ & $-31,58$ \\
\hline Z5 & 0,96 & 0,32 & $-0,64$ & $-66,66$ \\
\hline Z6 & 0,56 & 0,68 & 0,12 & 21,43 \\
\hline $\mathrm{Z7}$ & 0,079 & 0,085 & 0,006 & 7,59 \\
\hline Z8 & 5,15 & 2,17 & $-2,98$ & $-57,86$ \\
\hline
\end{tabular}

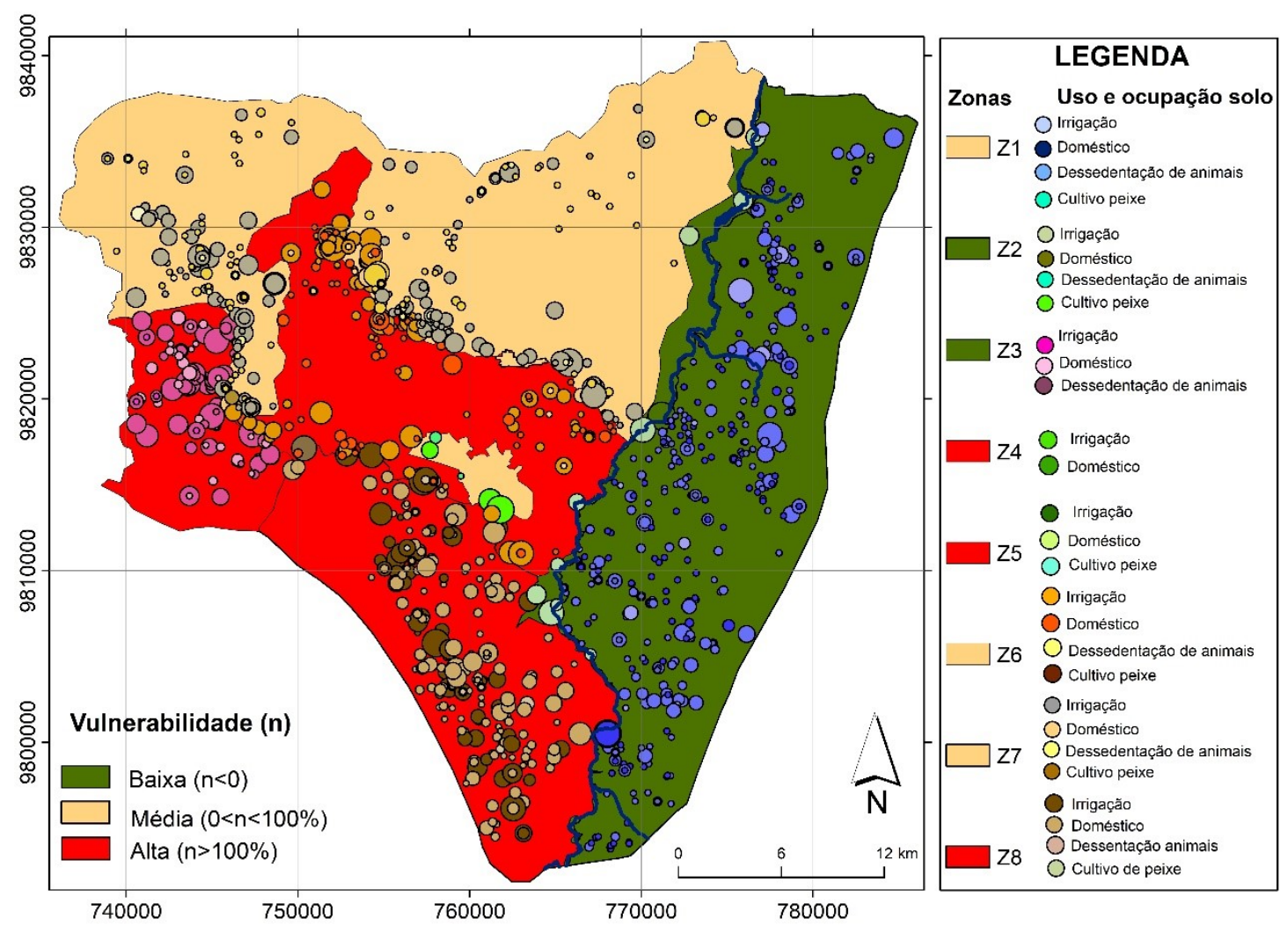

Figura 51. Vulnerabilidade hídrica nas 8 zonas definidas na $B B R C H$. 
A disponibilidade hídrica considera o aporte superficial e subterrâneo. Para o primeiro, estimou-se $37,24 \mathrm{~m}^{3} / \mathrm{s}$ que corresponde à oferta superficial da zona 3 (descarga total da $\mathrm{BBRCH}$ ) e o aporte subterrâneo total corresponde à soma da recarga lateral do glacial $(3,44 \mathrm{~m} 3 / \mathrm{s})$ mais a recarga devido às precipitações em cada zona obtida do produto da recarga local, em mm/ano, vezes a área de cada zona, como é mostrado na Tabela 34. Assim a disponibilidade subterrânea total é de $7,45 \mathrm{~m}^{3} / \mathrm{s}$ proveniente da recarga local $(3,61 \mathrm{~m} / \mathrm{s})$ mais a recarga lateral $\left(3,44 \mathrm{~m}^{3} / \mathrm{s}\right)$. Portanto, a disponibilidade hídrica total da BBRCH é de 44,69 $\mathrm{m}^{3} / \mathrm{s}$, para uma demanda total de $21,52 \mathrm{~m}^{3} / \mathrm{s}$.

Embora a região seja privilegiada por uma grande quantidade de fontes de água superficial, a bacia possui uma disponibilidade hídrica bastante limitada (em termos de qualidade, acesso, disposição para uso e potabilidade). A oferta de água por uso e ocupação do solo e abastecimento urbano é considerada insatisfatória, com base nos valores estimados na seção 6.9, que define como vulnerável as zonas 4, 5 e 8 (Tabela 34).

Tabela 34.Recarga local e lateral nas 8 zonas da BBRCH

\begin{tabular}{|c|c|c|c|c|c|c|c|c|}
\hline Zonas/Parâmetros & 1 & 2 & 3 & 4 & 5 & 6 & 7 & 8 \\
\hline $\begin{array}{l}\text { Precipitação } \\
\text { (mm/ano) }\end{array}$ & NP & 1020,70 & 766,89 & 676,94 & 719,57 & 540,17 & 460,64 & 732,83 \\
\hline $\begin{array}{l}\text { Recarga } \\
\text { (mm/ano) }\end{array}$ & NP & 227,96 & 68,08 & 35,80 & 47,15 & 4,57 & 2,77 & 61,79 \\
\hline $\begin{array}{l}\text { Evapotranspiração } \\
\text { (mm/ano) }\end{array}$ & NP & 649,81 & 605,31 & 548,45 & 580,44 & 455,82 & 389,61 & 576,44 \\
\hline $\begin{array}{l}\text { Escoamento } \\
\text { (mm/ano) }\end{array}$ & NP & 170,41 & 130,30 & 115,15 & 131,15 & 79,79 & 68,26 & 125,29 \\
\hline Área $\left(\mathrm{km}^{2}\right)$ & 503,2 & 371,87 & 38,20 & 224,35 & 90,05 & 16,36 & 1,44 & 235,08 \\
\hline $\begin{array}{l}\text { Precipitação } \\
\left(\mathrm{m}^{3} / \mathrm{s}\right)\end{array}$ & NP & 12,04 & 0,93 & 4,82 & 2,05 & 0,28 & 0,02 & 5,46 \\
\hline $\begin{array}{l}\text { Recarga local } \\
\left(\mathrm{m}^{3} / \mathrm{s}\right)\end{array}$ & NP & 2,69 & 0,08 & 0,25 & 0,13 & 0,0024 & 0,0001 & 0,46 \\
\hline $\begin{array}{l}\text { Recarga lateral } \\
\text { subterrânea } \\
\left(\mathrm{m}^{3} / \mathrm{s}\right)\end{array}$ & 3,44 & NP & NP & NP & NP & NP & NP & NP \\
\hline
\end{tabular}


Da análise realizada em cada zona, a proposta de planejamento na área de estudo está descrita na Tabela 35. Nela descreve-se o modelo de gestão a ser proposto com ações a serem tomadas a curto, médio e longo prazo. Em cada uma delas são mostrados os objetivos, o método, a zona de aplicação e os resultados esperados para cada ação, considerando prazos de 1, 5, 10 e 20 anos para aplicação de ditas ações. 
Tabela 35.Proposta de planejamento para a gestão de recursos hídricos na BBRCH a curto, médio e longo prazo.

\begin{tabular}{|c|c|c|c|c|c|}
\hline Ações & Tempo & Objetivos & Método & Zona & Resultados esperados \\
\hline \multirow{3}{*}{ 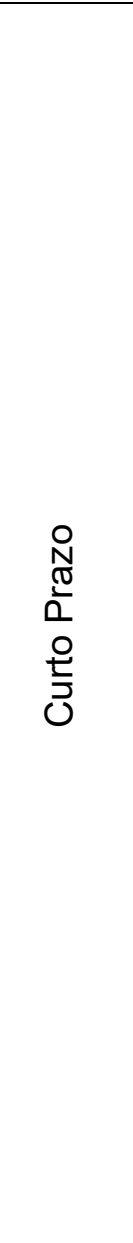 } & \multirow{3}{*}{$\begin{array}{l}\stackrel{\text { O }}{\text { V }} \\
-\end{array}$} & $\begin{array}{l}\text { Incrementar a rede de } \\
\text { monitoramento dos } \\
\text { dados } \\
\text { hidrometeorológicos. }\end{array}$ & $\begin{array}{l}\text { Instalação de estações hidrológicas } \\
\text { automáticas para medição de níveis de água } \\
\text { nos rios Chimborazo, Chibunga, Guano, } \\
\text { Alao, Blanco e Puela. } \\
\text { Instalação de estações meteorológicas } \\
\text { (especialmente nas zonas: Z4, Z2, Z8) }\end{array}$ & $\begin{array}{l}\text { Z1, Z2, } \\
\text { Z3, Z4, Z5 } \\
\quad \text { e Z8 }\end{array}$ & $\begin{array}{l}\text { Series espaciais e temporais de } \\
\text { dados hidrológicos para estimar } \\
\text { vazões ambientais. }\end{array}$ \\
\hline & & $\begin{array}{l}\text { Incrementar a rede de } \\
\text { coleta de água de } \\
\text { chuva. } \\
\text { Manter o } \\
\text { monitoramento de } \\
\text { Oxigênio e Deutério. }\end{array}$ & $\begin{array}{l}\text { Nas estações de llapo, guano, Riobamba e } \\
\text { Alao, continuar com a coleta de água de } \\
\text { chuva para as análises de isótopos estáveis } \\
\text { de Oxigênio e Deutério. Instalar novas } \\
\text { estações a diferentes altitudes. }\end{array}$ & $\begin{array}{l}\mathrm{Z1,} \text { Z2, } \\
\mathrm{Z4,}, \mathrm{Z}, \\
\mathrm{Z} 6, \mathrm{Z8}\end{array}$ & $\begin{array}{l}\text { Serie espaciais e temporais de } \\
\text { dados de água de chuva; } \\
\text { Cadastro de amostras para } \\
\text { análises de isótopos Oxigênio e } \\
\text { Deutério. }\end{array}$ \\
\hline & & $\begin{array}{l}\text { Identificar os usuários } \\
\text { (atores) de recursos } \\
\text { hídricos. }\end{array}$ & $\begin{array}{l}\text { Atores 1: Identificar aos usuários urbanos, } \\
\text { periurbanos e rurais de recursos hídricos } \\
\text { (superficiais e subterrâneos). } \\
\text { Atores 2. Institucionais: definir os objetivos, } \\
\text { visão, missão institucional com respeito aos } \\
\text { recursos hídricos (superficiais e } \\
\text { subterrâneos). }\end{array}$ & Z1 - Z8 & $\begin{array}{l}\text { Esquema gráfico de usuários } \\
\text { (atores); } \\
\text { Mapeamento dos atores, suas } \\
\text { principais atividades económicas, } \\
\text { renda e interesses e afetações. }\end{array}$ \\
\hline
\end{tabular}




\begin{tabular}{|c|c|c|c|c|c|}
\hline Ações & Tempo & Objetivos & Método & Zona & Resultados esperados \\
\hline \multirow{3}{*}{ 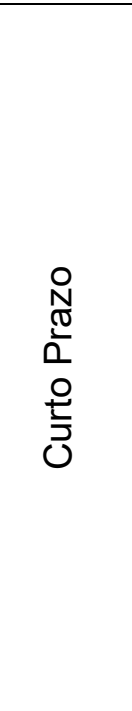 } & \multirow{3}{*}{$\begin{array}{l}\stackrel{O}{c} \\
\stackrel{\sigma}{\sigma} \\
\leftarrow\end{array}$} & $\begin{array}{l}\text { Gerar informações } \\
\text { atuais sobre a } \\
\text { demanda e oferta da } \\
\text { água. }\end{array}$ & $\begin{array}{l}\text { Estimar as demandas e ofertas da água, } \\
\text { considerando os usos e ocupação do solo } \\
\text { como descrito na seção } 6.9 \text { para dados a } \\
\text { partir do } 2011 \text {. }\end{array}$ & Z1-Z8 & $\begin{array}{l}\text { Mapas de oferta e demanda } \\
\text { hídrica a partir de } 2011 \text {. }\end{array}$ \\
\hline & & \multirow[t]{2}{*}{$\begin{array}{l}\text { Identificar as outorgas } \\
\text { regularizadas. }\end{array}$} & $\begin{array}{l}\text { Identificação de outorgas com problemas } \\
\text { legais e com renovações automáticas e com } \\
\text { excesso de vazão outorgada. }\end{array}$ & Z1 - Z8 & $\begin{array}{l}\text { Mapa de outorgas ilegais e } \\
\text { seguimento dos processos legais. }\end{array}$ \\
\hline & & & $\begin{array}{l}\text { Identificação de outorgas com problemas } \\
\text { legais e com renovações automáticas e com } \\
\text { excesso de vazão outorgada. }\end{array}$ & Z1 - Z8 & $\begin{array}{l}\text { Mapa de outorgas ilegais e } \\
\text { seguimento dos processos legais. }\end{array}$ \\
\hline
\end{tabular}




\begin{tabular}{|c|c|c|c|c|c|}
\hline Ações & Tempo & Objetivos & Método & Zona & Resultados esperados \\
\hline \multirow{4}{*}{ 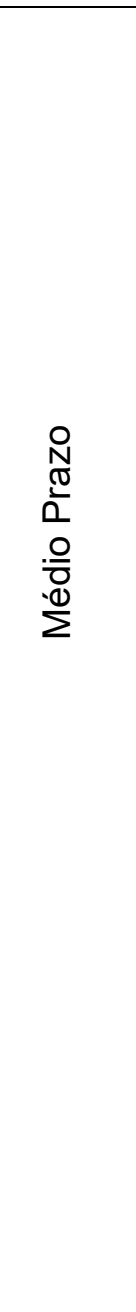 } & \multirow{4}{*}{ 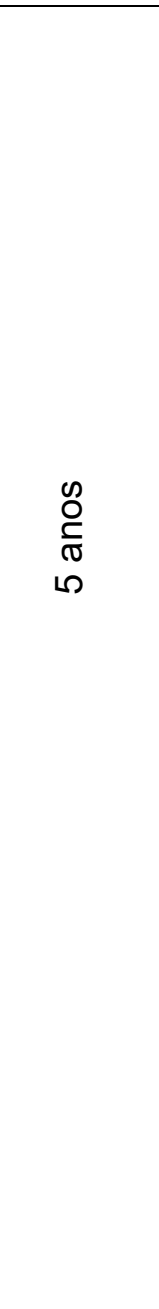 } & $\begin{array}{l}\text { Determinar as } \\
\text { recargas locais. }\end{array}$ & $\begin{array}{l}\text { Calibração das estimativas dos balanços } \\
\text { hídricos realizados. Considerando as recargas } \\
\text { locais (recargas devido às chuvas locais e } \\
\text { recargas laterais). }\end{array}$ & Z1, Z2 & Balanços hídricos; recargas locais. \\
\hline & & $\begin{array}{l}\text { Definir o plano de } \\
\text { bacia. }\end{array}$ & $\begin{array}{l}\text { Definir os critérios, prazos e procedimentos } \\
\text { para a elaboração dos Planos de Bacia. }\end{array}$ & Z1 - Z8 & $\begin{array}{l}\text { Plano de bacia avaliando as } \\
\text { mudanças climáticas (desgelo das } \\
\text { principais geleiras e sua influência } \\
\text { sobre os recursos hídricos). }\end{array}$ \\
\hline & & $\begin{array}{l}\text { Identificar as } \\
\text { outorgas } \\
\text { regularizadas. }\end{array}$ & $\begin{array}{l}\text { Identificação de outorgas com problemas } \\
\text { legais e com renovações automáticas e com } \\
\text { excesso de vazão outorgada. }\end{array}$ & Z1 - Z8 & $\begin{array}{l}\text { Mapa de outorgas ilegais e } \\
\text { seguimento dos processos legais. }\end{array}$ \\
\hline & & $\begin{array}{l}\text { Selecionar áreas } \\
\text { para novas } \\
\text { captações nas } \\
\text { bacias críticas. }\end{array}$ & $\begin{array}{l}\text { Identificação das principais unidades } \\
\text { hidrogeológicas e formações com } \\
\text { permeabilidade. }\end{array}$ & & $\begin{array}{l}\text { Mapa de formações com altas } \\
\text { permeabilidades. }\end{array}$ \\
\hline
\end{tabular}




\begin{tabular}{|c|c|c|c|c|c|}
\hline Ações & Tempo & Objetivos & Método & Zona & Resultados esperados \\
\hline \multirow{3}{*}{ 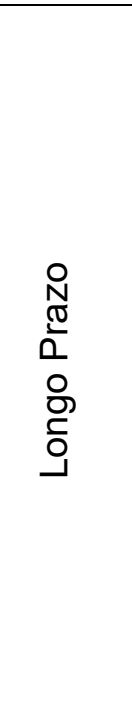 } & \multirow{3}{*}{$\begin{array}{l}\stackrel{\infty}{0} \\
\stackrel{2}{\pi} \\
\stackrel{0}{\circ}\end{array}$} & $\begin{array}{l}\text { Realizar o cadastro } \\
\text { de água de chuva. }\end{array}$ & $\begin{array}{l}\text { Nas estações de Ilapo, Guano, Riobamba e } \\
\text { Alao, continuar com a coleta de água de chuva } \\
\text { para as análises de isótopos estáveis de } \\
\text { Oxigênio e Deutério. Instalar novas estações } \\
\text { em diferentes altitudes. }\end{array}$ & Z1, Z6, Z7 & $\begin{array}{l}\text { Determinação da reta meteórica } \\
\text { local e da recarga local. }\end{array}$ \\
\hline & & $\begin{array}{l}\text { Cadastro dos } \\
\text { páramos. }\end{array}$ & $\begin{array}{l}\text { Identificação e caracterização das áreas de } \\
\text { páramo localizadas nos sopés dos vulcões } \\
\text { Chimborazo, Igualata, El Altar e Tungurahua. }\end{array}$ & Z1 e Z2 & $\begin{array}{l}\text { Determinar as características } \\
\text { hidrológicas dos páramos. }\end{array}$ \\
\hline & & $\begin{array}{l}\text { Determinar as } \\
\text { vazões ecológicas. }\end{array}$ & $\begin{array}{l}\text { Estimativas das vazões ecológicas e avaliação } \\
\text { dos impactos das obras hidráulicas existentes } \\
\text { (aquedutos) (Figura 52). }\end{array}$ & $\begin{array}{l}\text { Z1, Z2, } \\
\text { Z5, Z8 }\end{array}$ & $\begin{array}{l}\text { Relatórios sobre os impactos das } \\
\text { obras hidráulicas nas vazões dos } \\
\text { rios. }\end{array}$ \\
\hline
\end{tabular}




\begin{tabular}{|c|c|c|c|c|c|}
\hline Ações & Tempo & Objetivos & Método & Zona & Resultados esperados \\
\hline \multirow{3}{*}{ 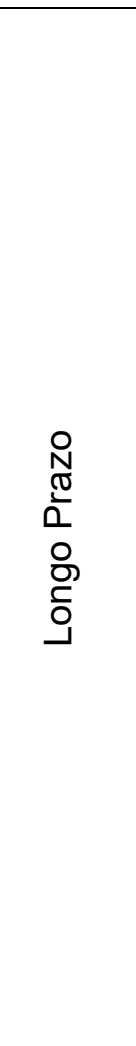 } & \multirow{3}{*}{ 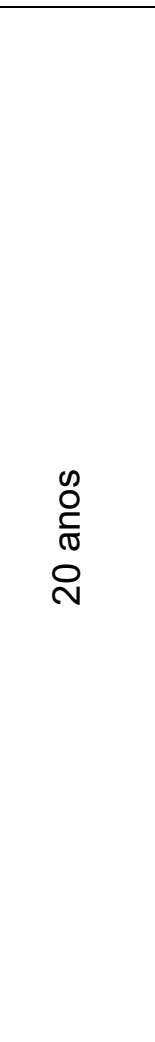 } & $\begin{array}{l}\text { Disponibilizar os } \\
\text { cadastros das series } \\
\text { temporais e } \\
\text { espaciais na } \\
\text { internet. }\end{array}$ & $\begin{array}{l}\text { Disposição dos cadastros nos principais sites } \\
\text { da SENAGUA, INHAMI, Universidades que } \\
\text { trabalham com recursos hídricos. }\end{array}$ & $\mathrm{Z1}-\mathrm{Z8}$ & $\begin{array}{l}\text { Sites SENAGUA, INHAMI, } \\
\text { Universidades com informações } \\
\text { hidrológicas, hidrogeológicas, } \\
\text { qualidade de água, gestão de } \\
\text { recursos hídricos. }\end{array}$ \\
\hline & & $\begin{array}{l}\text { Monitorar os níveis } \\
\text { de água nos } \\
\text { diferentes aquíferos. }\end{array}$ & $\begin{array}{l}\text { Instalação de poços de monitoramento em } \\
\text { llapo, Riobamba, Yaruquíes e Cubijíes }\end{array}$ & Z1 - Z8 & $\begin{array}{l}\text { Variações dos níveis de água nos } \\
\text { aquíferos. }\end{array}$ \\
\hline & & $\begin{array}{l}\text { Monitorar a } \\
\text { qualidade da água } \\
\text { superficial e } \\
\text { subterrânea. }\end{array}$ & $\begin{array}{l}\text { Coleta anual de amostras para análises de } \\
\text { qualidade de água (parâmetros físicos e } \\
\text { químicos) }\end{array}$ & Z1 - Z8 & $\begin{array}{l}\text { Cadastro e mapa de qualidade de } \\
\text { água. }\end{array}$ \\
\hline
\end{tabular}




\begin{tabular}{|c|c|c|c|c|c|}
\hline Ações & Tempo & Objetivos & Método & Zona & Resultados esperados \\
\hline 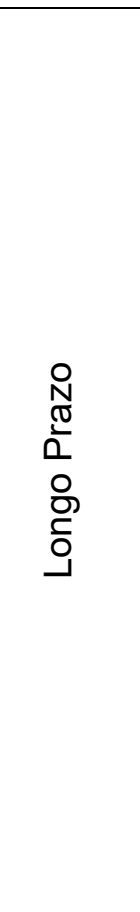 & $\begin{array}{l}\mathscr{0} \\
\stackrel{2}{c} \\
\frac{1}{\pi} \\
\stackrel{N}{2}\end{array}$ & $\begin{array}{l}\text { Propor novos } \\
\text { projetos para a } \\
\text { prevenção do } \\
\text { desabastecimento } \\
\text { hídrico. }\end{array}$ & $\begin{array}{l}\text { Proposta baseada na análise da } \\
\text { disponibilidade hídrica, custos sociais e } \\
\text { econômicos. } \\
\text { Consideração da disponibilidade do recurso a } \\
\text { jusante e a montante dos novos projetos } \\
\text { hidráulicos (transferência de água desde } \\
\text { bacias vizinhas; exploração de novos poços) e } \\
\text { dos aquedutos realizados para a captação de } \\
\text { água potável e para a agricultura. } \\
\text { Construir e reabilitar as obras de distribuição } \\
\text { dos sistemas de irrigação. Assim como realizar } \\
\text { estudos locais para a implementação de } \\
\text { reservatórios para a regulação dos fluxos dos } \\
\text { rios. }\end{array}$ & Z4 & $\begin{array}{l}\text { Incrementar a vazão de água } \\
\text { superficial e subterrâneas } \\
\text { disponível na BBRCH. }\end{array}$ \\
\hline
\end{tabular}




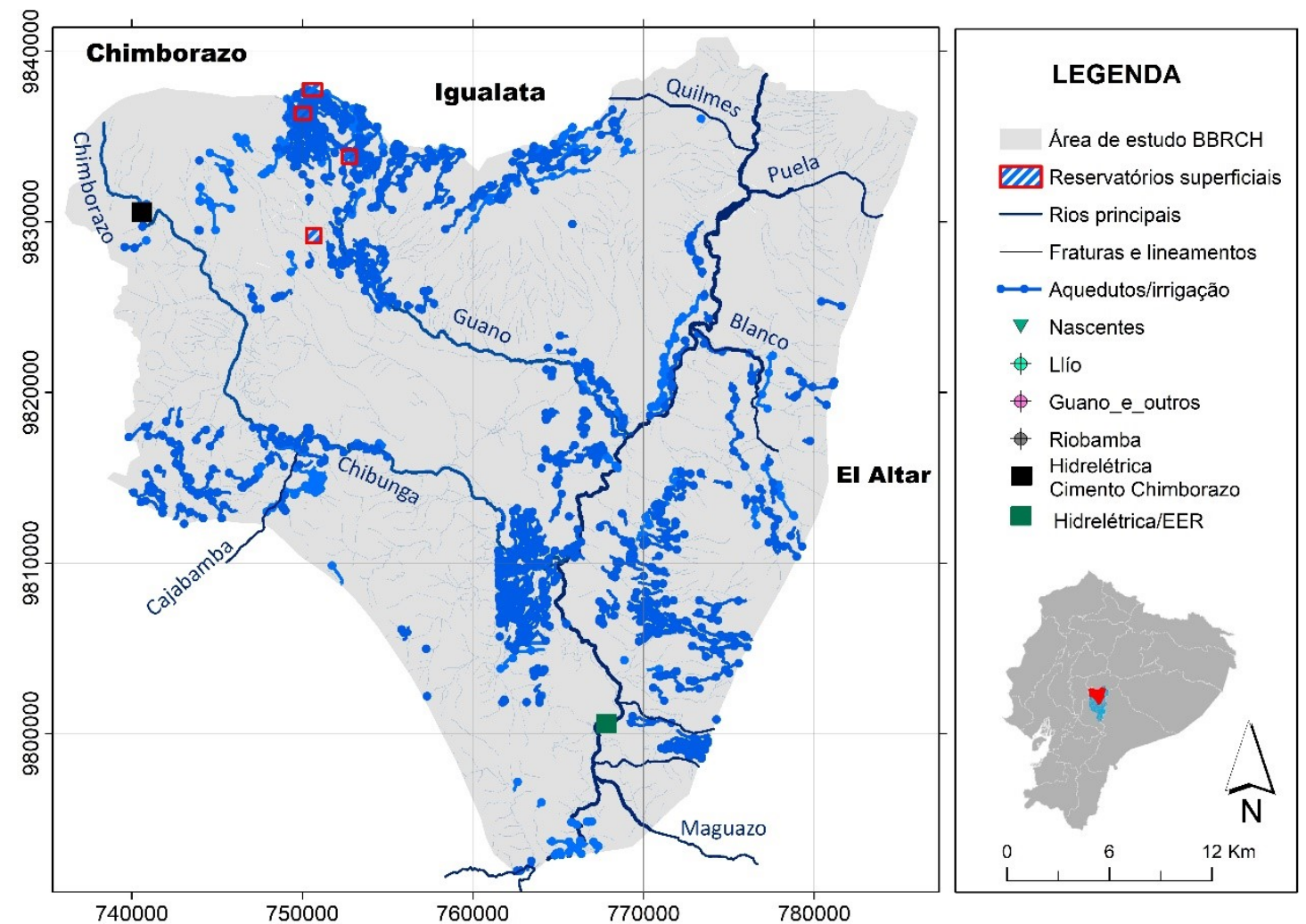

Figura 52. Aquedutos artesanais para captação de água superficial e posterior uso em irrigação.

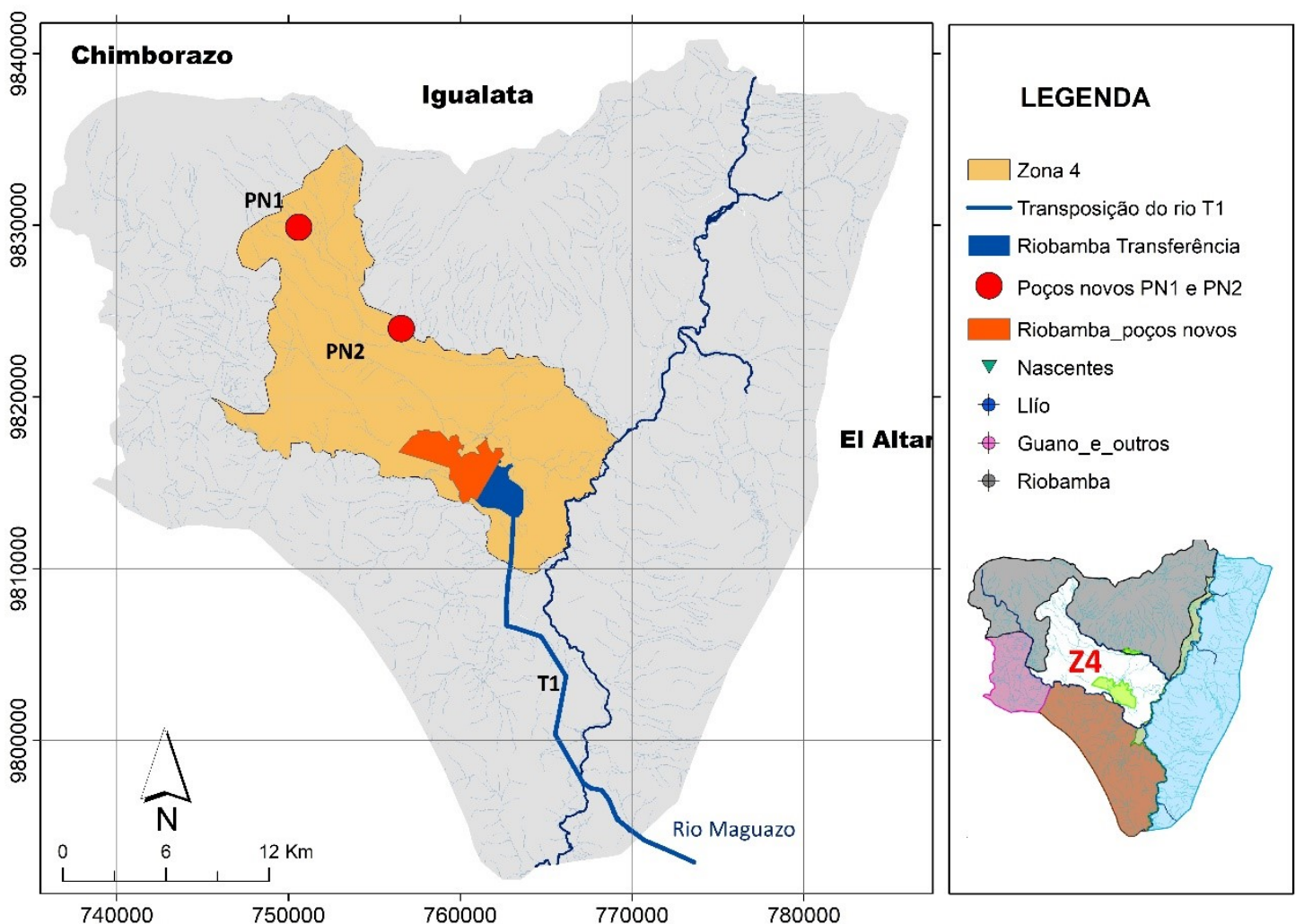

Figura 53. Proposta para prever um possível desabastecimento de água nas zonas com vulnerabilidade alta e média na $B B R C H$. 


\section{CONCLUSÕES E RECOMENDAÇÕES}

De acordo com as principais características geomorfológicas, geológicas, hidrológicas e hidrogeológicas observadas neste estudo, a Bacia do Baixo Rio Chambo foi dividida em 8 diferentes zonas, visando o gerenciamento de recursos hídricos:

- Zona de recarga da Cordilheira Ocidental, Chimborazo-Igualata (Z1): compreende as áreas situadas entre 4320 a 6268 m.s.n.m., com declividade muito acentuada (>7\%) e disponibilidade hídrica equivalente a $3,4 \mathrm{~m}^{3} / \mathrm{s}$;

- Zona de recarga da Cordilheira Oriental, Tungurahua e El Altar (Z2): abrange as localidades compreendidas entre 2000 a 5319, m.s.n.m., com altas declividades (>7\%) e disponibilidade hídrica igual a 112,74 m³;

- Zona de descarga do rio Chambo (Z3): possui declividade entre $2 \%$ e $7 \%$, além de apresentar contribuição de fluxo superficial $\left(62,07 \mathrm{~m}^{3} / \mathrm{s}\right)$ e subterrâneo provenientes das outras sete zonas;

- Zona central (Z4): caracteriza-se por apresentar baixas declividades (<2\%) e disponibilidade hídrica da ordem de 25,77 m³. Nestas zonas ocorrem as nascentes (San Pablo, 0,24 $\mathrm{m}^{3} / \mathrm{s}$ ) e os poços mais produtivos (0,35 m³ s, em Llío e Guano) da BBRCH;

- Zona sudoeste da BBRCH (Z5): possui disponibilidade hídrica equivalente a $12,22 \mathrm{~m}^{3} / \mathrm{s}$, declividades intermediárias (2\% a 7\%), sendo as mais acentuadas (>7\%) aquelas localizadas nas proximidades do vulcão Chimborazo. As declividades menos acentuadas (2\%), por sua vez, situam-se às margens do rio Cajabamba;

- Zonas urbanas de Riobamba (Z6) e Guano (Z7): possuem os menores valores de declividade (<2\%) e de disponibilidade hídrica (1,08 e 0,08 $\mathrm{m}^{3} / \mathrm{s}$, respectivamente);

- Zona sudeste de BBRCH (Z8): abrange áreas com declividade acentuada (>7\%) e baixa disponibilidade hídrica, aproximadamente $33,47 \mathrm{~m}^{3} / \mathrm{s}$.

Das 08 zonas supracitadas, seis (Z1, Z2, Z3, Z4, Z5 e Z8) compreendem áreas agrícolas, sendo a cultura do milho a que requer mais água, em função 
das dimensões da área de cultivo (24.441 hectares). A zona Z8 é a que demanda maior quantidade de água para irrigação $\left(4,9 \mathrm{~m}^{3} / \mathrm{s}\right)$, seguida da zona $Z 7$, com demanda de água para uso doméstico da ordem de $0,56 \mathrm{~m} 3 / \mathrm{s}$. Com relação às ofertas potenciais superficiais de água, a maior contribuição provém das zonas Z2 $\left(112,74 \mathrm{~m}^{3} / \mathrm{s}\right)$ e $Z 3\left(62,07 \mathrm{~m}^{3} / \mathrm{s}\right)$. A menor contribuição de água abrange as áreas urbanas de Riobamba (Z6), 0,70 m³/s, e Guano (Z7), 0,10 m³/s.

O modelo hidrogeológico conceitual proposto considera como recarga lateral a contribuição das águas de degelo provenientes das geleiras dos vulcões Chimborazo $\left(1,9 \mathrm{~m}^{3} / \mathrm{s}\right)$ e Igualata $\left(1,5 \mathrm{~m}^{3} / \mathrm{s}\right)$, na Cordilheira Ocidental, e daquelas oriundas dos vulcões El Altar e Tungurahua, situados na Cordilheira Oriental, que juntas perfazem um total de $112,74 \mathrm{~m}^{3} / \mathrm{s}$. As zonas $Z 4, Z 5$ e Z8 possuem recarga local decorrente da precipitação mais acentuada nestas localidades $\left(27,77 \mathrm{~m}^{3} / \mathrm{s} ; 12,22 \mathrm{~m}^{3} / \mathrm{s} ; 33,47 \mathrm{~m}^{3} / \mathrm{s}\right)$ do que nas zonas 6 e 7 . A descarga compreende a zona 3 (rio Chambo), constituindo a área de confluência da drenagem superficial da $\mathrm{BBRCH}$. As direções preferenciais de fluxo subterrâneo são coincidentes com as das drenagens superficiais. Desta forma, as águas subterrâneas movimentam-se desde o Chimborazo, Igualata (Z1) e El Altar (Z2), em direção ao rio Chambo (Z3).

$\mathrm{Na}$ área ocorrem três aquíferos, do tipo multicamadas: Llío-Guano, Riobamba e Yaruquíes Cubijíes. O Aquífero Llío-Guano, localizado nas proximidades dos vulcões Chimborazo e Igualata, é do tipo livre, de porosidade dupla, espessura média de $200 \mathrm{~m}$, associado aos depósitos vulcanogênicos do Chimborazo (superior) e Igualata (inferior). Tem vazão média de $0,27 \mathrm{~m}^{3} / \mathrm{s}$, condutividade hidráulica da ordem de $6,0 \times 10^{-6} \mathrm{~m} / \mathrm{s}$ e o nível de água médio, igual a $65 \mathrm{~m}$ nos poços que atravessam os depósitos do Chimborazo e $140 \mathrm{~m}$, naqueles perfurados na Formação Cizarán.

O Aquífero Riobamba situa-se nas regiões de vales que ocorrem nas proximidades das cidades de Riobamba e Guano. Ele também é do tipo livre, de porosidade primária, composto pelos depósitos das formações Riobamba (superior) e Cizarán (inferior). Sua espessura média é de $150 \mathrm{~m}$, vazão igual a $0,012 \mathrm{~m}^{3} / \mathrm{s}$ e condutividade hidráulica equivalente a $4,3 \times 10^{-5} \mathrm{~m} / \mathrm{s}$. Os valores 
médios do nível de água variam de acordo com a formação geológica explorada, entre 90 (Formação Riobamba) e 160 m (Formação Cizarán).

O Aquífero Yaruquíes é do tipo suspenso, com extensão local, restrito às áreas próximas ao povoado homônimo. Sua espessura média é de $75 \mathrm{~m}$, vazão igual a 0,016 m³ e condutividade hidráulica correspondente a 1,9 × 10-7 m/s. Os valores médios de nível d'água variam entre 38 m (Formação Yaruquíes) e 110 m (Formação Riobamba).

Os resultados das análises físico-químicas e químicas das amostras de águas subterrâneas indicaram a ocorrência de três tipos hidroquímicos predominantes. O primeiro deles engloba as águas bicabornatadas cálciomagnesianas (aquíferos Llío-Guano e Riobamba) e o segundo, as águas bicabornatadas sódicas (Aquífero Yaruquíes) e sulfatadas (Cubijíes).

As águas do Aquífero Llío-Guano e Riobamba são do tipo bicabornatadas cálcio-magnesianas, apresentam valores médios de $\mathrm{pH}$ entre 6,5 e 7,5, temperatura de 12,0 a $18,3^{\circ} \mathrm{C}$ e de condutividade elétrica, de 432,4 a $1.320,9$ $\mu \mathrm{S} / \mathrm{cm}$. O bicarbonato é o íon predominante, sendo o cálcio e magnésio, os cátions. Salienta-se que as amostras de água do Aquífero Riobamba são neutras e mais mineralizadas quando comparadas às do Aquífero Llío-Guano.

As águas do Aquífero Yaruquíes são bicabornatadas sódicas, apresentam valores de $\mathrm{pH}$ igual a 7,5, condutividade elétrica igual a 1.695,7 $\mu \mathrm{S} / \mathrm{cm}$ e temperatura equivalente a $22,8^{\circ} \mathrm{C}$. Os íons predominantes são carbonato $(600$ mg/L) e sódio (190,2 mg/L). Foram detectadas, também, altas concentrações de sulfato (273 $\mathrm{mg} / \mathrm{L})$.

As amostras das nascentes, por sua vez, apresentam uma composição que varia desde bicabornatada cálcio-magnesiana (nascente San Pablo, Llío e Riobamba) a sulfatada cálcio-magnesianas (nascentes em Cubijíes). As águas das nascentes coletadas nas proximidades dos povoados de Llío e Riobamba apresentam valores médios de pH igual a 5,7, condutividade elétrica entre 479,3 e $675,6 \mu \mathrm{S} / \mathrm{cm}$ e temperatura de 10,9 a $15^{\circ} \mathrm{C}$. Por sua vez, as águas da nascente em Cubijíes possuem valores médios de pH igual a 7,4, condutividade elétrica equivalente a $1.415,1 \mu \mathrm{S} / \mathrm{cm}$, portanto mais mineralizadas, e temperatura média de $19,6^{\circ} \mathrm{C}$. 
Os valores de $\delta^{2} \mathrm{H}$ e $\delta^{18} \mathrm{O}$ nas amostras de água do Aquífero Llío-Guano variaram, respectivamente, de $-94,90$ a $-93,90 \%$ e $-13,10$ a $-12,95 \%$. No Aquífero Riobamba, estes isótopos apresentaram resultados entre -96,30 e $79,50 \%$ e -12,88 e -10,87\%o. Por fim, no Aquífero Yaruquíes as razões isotópicas foram de $-89,90 \%$ e $-11,34 \%$. Nas amostras de água das nascentes, os valores de $\delta^{2} \mathrm{H}$ e $\delta^{18} \mathrm{O}$ oscilaram entre: i) $-97,20$ e -93,80\%o/-13,50 e -12,86\%o (LlíoGuano); ii) -82,90\% e -11,09\% (Riobamba); iii) -87,00 e -84,60\%o/-10,93 e $11,20 \%$ (Cubijíes). As composições químicas das águas do aquífero Llío-Guano e as dos poços situados na porção ocidental da cidade de Riobamba são diferentes daquelas coletadas nos poços localizados na porção oriental da mesma cidade do Aquífero Yaruquíes e das nascentes em Cubijíes. Tal diferença está, provavelmente, relacionada às águas de diferentes origens, além de mistura de águas nos poços proveniente de diferentes profundidades. As assinaturas isotópicas determinadas reforçam tal hipótese.

Os resultados das análises isotópicas são coincidentes com os resultados mostrados nos parâmetros físicos e químicos. A ocorrência dos tipos de águas com características físicas, químicas e isotópicas diferentes evidenciam duas fontes de águas distintas. Estas fontes poderiam estar localizadas no vulcão Chimborazo e El Altar. Este último, pode ser o responsável das altas concentrações de sulfato e sódio nas águas do Aquífero Yaruquíes e nas nascentes de Cubijíes, refletindo uma forte influência de vulcanismo ou hidrotermal. Corrobora com essa avaliação o fato das águas sulfatadas e sódicas terem maior temperatura que aquelas relacionadas às águas provindas dos vulcões a oeste, bem como a nítida variação nas razoes isotópicas.

As retas meteóricas para Ilapo, Guano e Riobamba para 8 meses amostrados localizam-se tanto sobre a reta meteórica global (Rozanski et al., 1993) quanto a reta meteórica de Quito (Manciati, 2014). Ou seja, as chuvas nas três regiões obedecem às chuvas mundiais e da cidade de Quito. No período de estiagem (dezembro de 2016 a fevereiro de 2017) essas águas se tornam mais enriquecidas $\left(-14,27 \%\right.$ e $-7,48 \%$, para $\delta^{180}$, e $-103,1 \%$ e $-49,5 \%$, para $\left.\delta^{2} \mathrm{H}\right)$ quando comparadas com amostras coletadas no período chuvoso (outubro a 
novembro de 2016 e março a maio de 2017). Caso a origem da umidade seja a mesma ao longo do ano, isso seria atribuído ao efeito quantidade.

Os usuários de recursos hídricos superficiais são constituídos principalmente por aqueles que vivem em comunidades rurais e periurbanas, localizadas em áreas mais vulneráveis (risco vulcânico, falhas ativas, altas declividades). Tais comunidades têm como principal fonte econômica a atividade agrícola (principalmente a cultura do milho), onde a demanda de água $(19,19$ $\mathrm{m}^{3} / \mathrm{s}$ ) para irrigação é a maior nas zonas 4,5 e 8 . A alta demanda faz com que os usuários construam aquedutos e captações artesanais de água superficial, sem técnica e planejamento adequados, nas zonas com maior oferta hídrica ( $Z 1$, Z2 e Z4). Atualmente, as zonas com um possível déficit hídrico (Z5, Z6, Z7 e Z8) satisfazem suas necessidades de demanda, principalmente, a partir da oferta de água das zonas 1, 2 e 4.

Para os usuários de recursos hídricos subterrâneos constituídos principalmente pela EP-EMAPAR, a oferta instalada atende à demanda de uso doméstico e abastecimento público. No entanto, alguns bairros (principalmente aqueles localizados na região leste da cidade de Riobamba) sofrem com o abastecimento parcial de água, devido a problemas na rede de distribuição, mas não na oferta instalada de água.

A perda de quantidade ou qualidade dos mananciais superficiais e subterrâneos, atualmente utilizados na área de estudo para satisfazer as demandas domésticas e de irrigação, implicará em transtornos irreparáveis, sobretudo ao sistema de abastecimento urbano das zonas 6 e 7. Isto causará conflitos no aproveitamento de recursos hídricos entre os diferentes usuários, principalmente nos setores agrícola e doméstico.

A implementação dos conceitos e requisitos para a gestão de recursos hídricos na área de estudo está apenas começando. Os mecanismos técnicos para o planejamento e disposição da informação (sistema de informação sobre recursos hídricos), a participação da comunidade na gestão da água (comitês de bacia) e o aporte para a criação de uma política nacional de recursos hídricos, que forneça um quadro institucional para os gestores de recursos hídricos, não 
foram implementados devido à falta de informações técnicas (hidrológicas, hidrogeológicas, hidroquímicas), sociais e econômicas, aliadas à ausência de compreensão do conceito entre os usuários da água.

$\mathrm{Na}$ Bacia do Baixo Rio Chambo aplicaram-se políticas públicas equivocadas, quando não ausentes, calcadas especialmente na implantação de pequenos aquedutos para irrigação, altamente vulneráveis aos riscos vulcânicos. Ademais, ressalta-se também que a falta de política de gestão das águas foi a tônica da manutenção do quadro regional. Medidas paliativas para aliviar a demanda das populações rurais, periurbanas e urbanas desassistidas, como a utilização de carros-pipa para o transporte de água das nascentes para os bairros de baixa renda da cidade de Riobamba, aquedutos artesanais, entre outros, ainda continuam sendo o foco dos representantes das comunidades e dos políticos locais. A partir de 2014, implantou-se nos Governos Autônomos Descentralizados (GADs) uma filosofia de controle do uso por meio da proposição e revisão de instrumentos como a outorga e a cobrança pelo uso da água bruta, a geração de planos de recursos hídricos para as bacias hidrográficas e para os GADs, bem como, a criação de comitês de bacias. No entanto, na pratica, tais ações ainda não são executadas.

A transposição de águas do Rio Alao e Maguazo requer planejamento e financiamento de modo a tornar esta prática efetivamente útil para as populações localizadas nos bairros da zona leste da cidade de Riobamba. As questões operacionais do projeto devem ser melhor estudadas, com uma visão mais global de integração das fontes existentes e dos cenários das tão aguardadas mudanças climáticas. Questões como redução de perdas de água e de eficiência nos usos na irrigação, onde os consumos são maiores, devem ser melhor analisadas no projeto. Também, precisam ser estudados outros aspectos, tais como, a distribuição da terra, culturas a serem irrigadas, infraestrutura complementar e logística de escoamento de produção.

Da mesma forma, os projetos de construção de novos poços na zona 4 necessitam ser melhor avaliados sob uma ótica sistêmica e de futuro, uma vez que são grandes as pressões sobre o uso de recursos hídricos na bacia e dos potenciais conflitos gerados, no que se refere ao uso da água em diversos setores da sociedade, agricultura, indústria e doméstico. 


\section{REFERÊNCIAS}

Alurralde, J., Salon, P., \& Orellana, R. (2003). Legislación de aguas en Bolivia; encontrando bases comunes. 13(36), 134-149. Mérida, Venezuela.

Alvarado, A., Audin, L., Nocquet, J., Jaillard, E., Mothes, P., \& Jarr. (2016). Partitioning of oblique convergence in the Northern Andes subduction zone: Migration history and the present-day boundary of the North Andean Sliver in Ecuador. Tectonics, 35(5), 1048-1065.

ANA. (2009). Dirección de Conservación y Planeamiento de Recursos Hídricos. Lima.

Aspden, J., \& Litherland, M. (1992). The geology and Mesozoic collisional history of the Cordillera Real, Ecuador. Tectonophysics, 205, 187-204.

Baldock, J. (1982). Geology of Ecuador: Explanatory bulletin of the National Geological map of the Republic of Ecuador 1:1'000.000 scale. Dirección General de Geología y Minas (DGGM)., Quito.

Baraer, M., Mark, G., McKenzie , J., Condom, T., Bury, J., \& Huh, K. (2012). Recesión de glaciares y recursos hídricos en la Cordillera Blanca de El Perú. Journal of Glaciology, 58(207). doi:10.318/2012JoGsp11J186

Barba, D. (2006). Estudio vulcanológico del complejo volcánico ChimborazoEcuador. Tesis de grado. Escuela Politécnica Nacional. Quito.

Barba, D., Robin, C., Samaniego, P., \& Eissen, J. (2008). Holocene recurrent explosive activity al Chimborazo volcano (Ecuador). Journal of Vulcanology and Geothermal Research, 176, 27-35.

Barberi, F., Coltelli, M., Ferrara, G., Innocenti, F., Navarro, J., \& Santacrocer, R. (1988). Plio-Quaternary volcanism in Ecuador. Geol. Mag, 1-14.

Barrientos, J. (2011). Modelo de Gestión integrada de recursos hídricos de las cuencas de los ríos Moquegua y Tambo. Piura: Facultad de Ingeniería, Maestría en Gestión y Auditorías Ambientales.

Bates, B., Kundzewicz, Z., \& Palutikof, J. (2008). El cambio climático y el agua. Ginebra: Documento técnico del Grupo Interbubernamental de Expertos sobre el cambio climático .

Bauer, C. (2004). Chilean water law as a model for international reform. Resources for the future. 
Bernard, B., \& Andrade, D. (2011). Volcanes Quaternarios del Ecuador Continental. Quito.

Bernex, N., \& Tejada, M. (2010). Cambio Climático, retroceso glaciar y gestión integrada de los recursos hídricos. Lima.

Borsoni, Z., \& Torres, S. (1997). A política de recursos hídricos no Brasil. Revista do BNDS, 4(8), 143-166.

Bradley, R. V. (2006). Threats to Water Suppl;ies in the Tropical Andes. 17551756.

Brasil. (1988). Constituição Federal. Diário Oficial da República Federativa do Brasil.

Brasil. (1997). Ley Federal.Diário Oficial da República Federativa do Brasil.

Brasil. (2000). Resolução No. 12 do Conselho Nacional de Recursos Hídricos $(\mathrm{CNRH})$.

Burlado, P., \& Pellicciotti, F. (2002). Modelling Mountanous Water Systems between Learning and Speculating Looking for Challenges. Nordic Hydrology., 33(1), 47-74.

Bustillos, J. (2008). Las avalanchas de escombros del Tungurahua. Tesis de Grado. Escuela Politécnica Nacional, 150. Quito.

Cáceres, B. (2010). Actualización del inventario de tres casquetes glaciares del Ecuador, 84. Nice.

Cáceres, B., Ramirez , J., Francou, B., Eissen, J. P., \& Taupin , J. (2004). Determinación del volumen del casquete de hielo del volcán Cotopaxi. IRD, INAMHI, IG-EPN, INGEOMINAS, Quito.

Centro de Gestao e Estudos Estratégicos. (2012). A Questao da Água no Nordeste. Brasília, Brasil.

CEPAL. (1998). Manejo Integrado del recurso agua con la perspectiva de los Principios de Dublin. Comisión Económica para América Latina y El Caribe,, 64. Recuperado el 3 de 2016

CEPAL. (2012). Diagnóstico de las Estadísticas del agua en el Ecuador. Senagua, Informe de Gestión.

CEPAL. (2015). Diagnóstico de las Estadísticas del agua en el Ecuador.

Clapperton, C., \& Vera, R. (1886). The Quaternary glacial sequence in Ecuador: a reinterpretation of the work of water sauer. Journal of Quaternary Science, 1, 45-56. 
Clark, I., \& Fritz, P. (1997). Environmental Isotopes in Hydrogeology. New York: Lewis Publishers.

CNRH. (2007). Gestión integral de los recursos hídricos en el Ecuador: información básica. Quito: Consejo Nacional de Recursos Hídricos.

Comité de la subcuenca del río Chambo. (2015). Aportes a la planificación para la gestión integral de los recursos hídricos. Consorcio CESA-AVSF, Quito. Corporación de Desarrollo e Investigación Geológico-Minero-Metalúrgica y el British Geologycal Survey (CODIGEM-BGS). (1997). Mapa geológico de la Cordillera Occidental entre $0^{\circ}$ y $1^{\circ} \mathrm{S}$, escala 1:200.000.

Criag, H. (1961). Isotopic variation in meteoric waters. Sciences, 133:1702.

Custodio, E., \& LLamas, M. (2001). Hidrología Subterránea (Vol. 1). (Omega, Ed.) Barcelona.

De Miguel Fernandez, C. (1999). Hidrogeología Aplicada. La Habana, Cuba. $357 p$.

Dixon, W., \& Chiswell, B. (1994). Isotopic study of alluvial groundwaters, southwest Lockyer Valley. Hydrological Processes, 8(4), 359-367.

Dourojeanni, A. (2002). Recursos Naturales e Infraestructura: Evolución de Políticas Hídricas en América Latina y el Caribe, Naciones Unidas. CEPAL ECLAC, Serie 51.

Engineers, A. -A. (1969). Task Force on Effect of Urban Development on Flood Discharges, Committee on Flood Control, Effect of Urban Development on Flood Discharges - Current Knowledge and Future Needs. Journal Hydraulics Division, 95 (HY1), 287 - 309.

EPCE. (2013). Empresa Pública Cementera. Obtenido de https://www.cemento.gob.ec/p/productos-servicios/union-cementeranacional/

Equador. (2014). Registro oficial No. 305. Obtenido de www.agua.gob.ec/ley de recursos h\{idricos II suplemento 305-6-08-204

Equador. (2015). Retrieved from https://www.agua.gob.ec/

Equador. (2018). Retrieved from www.lexis.com.ec

FAO. (1991). El estado mundial de la agricultura y la alimentación. (C. F. Agricultura, Ed.) Políticas y cuestiones agrícolas: los años ochenta y perspectivas para los noventa(24). 
Foster, S. (2012). Hard rock aquifers in tropical regions using science to infor development and management policy. Hydrogeological Journal., 20(4), 659-672.

Francou, B. (2013, Septiembre). El rápido retroceso de los glaciares en los andes tropicales: Un desafío para el estudio de la dinámica de los ecosistemas de alta montaña. Ecología en Bolivia.

Francou, B. (Septiembre de 2013). El rápido retroceso de los glaciares en los Andes tropicales: Un desafío para el estudio de la dinámica de los ecosistemas de alta montaña. Ecología en Bolivia. ISSN 1605-2528, 6971.

Francou, B., \& Vincent, C. (2007). Les glaciers à l'epreuve du climat. Paris.

Francou, B., Ramirez, E., Cáceres, B., \& Mendoza, J. (2000). Glacier evolution in the tropical Andes during the last decades of the 20th century. Chacaltaya, Bolivia and Antizana, Ecuador. Ambio, 416-422.

Francou, B., Ribstein, P., Tiriau, E., \& Saravia, R. (1995). Monthly Balance and water discharge inter tropical glacier. The Zongo glacier, Cordillera Real, bolivia $16^{\circ}$ S. Journal of Glaciology, 61-67.

Francou, B., Vuille , M., Wagnon , P., Mendoza, J., \& Sicart, J. (2003). Tropical climate change recorded by a glacier in the central Andes during the last decades of the twentieth century: Chacaltaya, Bolivia, 16S. Journal of Geophysical Research, 108(D5, 4154). doi:doi:10.1029/2002JD002959

Fredericks, J., Labadie, J., \& Altenhofen, J. (1998). Decision Suport System for Conjunctive Stream Aquifer Management. Journal of water resources planning and management.

Fullgar, I., Brodie, R., Sundaram, B., Hostetler, S., \& Baker, P. (2006). Managing connected surface water and groundwater Resources, Science for Decision Makers. Australia: Australian Government Bureau of Rural Sciences.

Gat, J. (1980). The isotopes of hydrogen and oxigen in precipitation, in Handbook of Environmental Isotope. (Elsevier, Ed.) Geochemistry.

Granziera, M. (2001). Direito de águas: disciplina jurídica de águas doces. São Paulo: Atlas. 
Gutscher, M., Malavieille, J., Lallemand, S., \& Collot, J. (1999). Tectonic segmentation of the North Andean margin: impact of the Carnegie Ridge collision. Earth and Platenary Science Letters, 168, 255-270.

GWP. (2002). Integrated Water Resources Management, Technical Advisory Committee. Estocolmo: Global Water Parthership.

GWP. (2009). Manual para la Gestión Integrada de Recursos Hídricos en Cuencas.

Hall, M., \& Beate, B. (1991). El volcanismo Plio-Cuaternario en los Andes del Ecuador. (Vol. 4). Quito.

Hosono, T., Wang, C., Umewaza, Y., Nakano, T., Onodera, S., Nagata, T., \& Yoshimizu, C. (2011). Multiple isotope $(\mathrm{H}, \mathrm{O}, \mathrm{N}, \mathrm{S}$ and $\mathrm{Sr}$ ) approach eluciates complex pollution causes in the shallow groundwater of the Tapei urban area. Journal of Hydrology, 397(1-2), 23-36. doi:10.1016/j.hydro.2010.11.25

Hughes, R., \& Pilatasig, L. (2002). Cretaceus and Terciary terrane acretion in the Cordillera Occidental of the Ecuadorian Andes. Tectonophysics, 345, 2948.

IAEA, International Atomic Energy Agency. (2013). Procedimiento técnico para las estaciones de la Red Global de Isótopos en la Precipitación.

Immerzeel, Luduvicus, P., Beek, V., Marc, F., \& Bierkens, P. (2010). Climate Change will affect the Asian water towers. Science, 328, 1382-1385. doi:10.1126/science. 1183188

INEC. (2010). Estadísticas y Censos.

Instituto de Investigación para el Desarrollo IRD. (2009).

IPCC. (2008). Quarto Relatório de Avaliação do Painel Intergovernamental sobre Mudanças Climáticas.

IPCC. (2012). Recent climate change inferred from glacier evolution in the Tropical Andes. Bolivia.

IPCC. (2013). Annex B: Glossary. En Climate Change 2013: The Physical Science Basis. IPCC Working Group I Contribution to AR5. Cambridge: Cambridge University Press.

Jacobi, P., \& Fracalanza, A. (2007). Comitês de Bacias Hidrográficas no Brasil.

Desafíos de fortalecimento da Gestão Compartilhada e participativa. Desenvolvimento e Meio Ambiente, 11-12. 
Kebede, S., Travi, Y., Asrat, A., Alemayehu, T., Ayenew, T., \& Tessema, Z. (2008). Groundwater origin and flow along selected transects in Ethiopian rift volcanic aquifers. Hydrogeology Journal, 16(1), 55-73.

Komor, S., \& Emerson, D. (1994). Movements of water, solutes, and stable isotopes in unsaturated sones of two sands plains in the upper Midwest. Water Resources Research, 30(2).

La Frenierre, J. (2014). Assessing the Hydrologic Implications of Glacier Recession and the Potential for Water Resources Vulnerability al Volcán Chimborazo, Ecuador. The Ohio State University.

Landon, M., Delin, G., Komor, S., \& Regan, E. (2000). Relation of pathways and transit times of recharge water to nitrate concentrations using stable isotopes. Groundwater, 38(3), 381-395.

Litherland, M., Aspend, J., \& Jemielita, R. (1994). The metamorphic nelts of Ecuador. Nottingham, British Geological Survey(11), 147.

Llamas, M. (2007). Aguas subterráneas: de la revolución silenciosa a los conflictos clamorosos. R. Acad. Ciencias Exactas. Física. Natural, 101(1), 175-181.

Lovato, V. (2010). Informe técnico de la investigación de aguas subterráneas y prospección Geofísica de superficie en el sector Yaruquíes, Riobamba.

López, \& Camacho, B. (2001). Estrategia de respuestas frente a las sequias, la utilización conjunta de aguas superficiales y subterráneas en uso y gestión eficiente del agua en abastecimientos urbanos (1). En López, Los caminos del agua (págs. 92-106). Madrid: Fundación Canal Santa Isabel II.

López, T., Manzano, M., \& Ramírez, A. (enero-febrero de 2017). Disponibilidad hídrica bajo escenarios de cambio climático en el Valle de Galeana, Nuevo León, México. Tecnología y Ciencias del agua, III(1), 105-114.

Madroñero, S. (2006). Manejo del recurso hídrico y estrategias para su gestión in tegral en la microcuenca Mijitayo, Pasto Colombia. Maestría Programa de Educación para el Desarrollo y la Conservación. CATIE.

Magalhães, J. (2007). Indicadores Ambientais e recursos hídricos:realidade e perspectivas para o Brasil a partir da experiência francesa. Rio de Janeiro: Bertrand Brasil. 
Maldener, C. (2010). Recarga de auífero em área urbana: estudo de caso de Urânia (SP). São Paulo: Dissertação (Mestrado). IGc/USP.

Mancheno. (2010). Análisis de la problemática y ampliación del sistema de agua potable en la ciudad de Riobamba. Carrera de Ingeniería Civil. Escuela Politécnica del Ejército.

Manciati, C. (2014). Estude de linteraction surface-souterrain du systeme aquifere Tumbaco-Cumbayá en Equateur, avec un aproche hydrodynamique el geochimique. 383. Montpellier, Francia.

Mark, B., Bury , J., McKenzie , J., French , A., \& Baraer, M. (2010). Climate changeantropicalAndeanglacierecession: evaluating hydrologic changes and liveihood vulnerability in the Cordillera Blanca, Perú. Asso. Am.Geogra, 100(4), 794-805.

Marqueto, L., Simões, J., Cassassa, G., Introne, D., \& Dos Santos, E. (2015). Variações na composição isotópica de oxigênio na neve superficial ao longo de uma travessia antártica. Pesquisas em Geociências, 227-238.

Martínez, P., \& Patiño, C. (2012). Efectos del cambio climático en la disponibilidad de agua en México. Tecnología y Ciencias del Agua, III(1), 5-20.

Mathieu, R., \& Bariac, T. (1996). A numerical model for the simulation of stable isotope profiles in drying soils. Journal of Geophysical Research. An AGU Journal. doi:org/10.1029/96JD00223.

Meehl, G. A. (2007). Global Climate Projections. In: Solomon, S. D. et. al. (Ed). Climate Change 2007: The Physical Science Basis. Contribution of Working Group I to the Fourth Assessment Report of the Intergovernmental Panel on Climate change. Climate Change.

Millot, R., Innocent, C., Négrel, P., \& San Juan, B. (2011). Chemical multi-isotopic (Li-B-Sr-U-H-O) and thermical characterization of Triassic formation waters from the Paris basin. Chemical Geology, 283(3-4).

Mondaca, G. (2011). El enfoque de gestión integral de recursos hídricos por cuencas, como propuesta base de la regulación hídrica en bolivia. ¿Por qué la importancia de una visión nde cuencas en la futura ley de aguas? Revista Virtual REDESMA., 5 (1).

Moser, H., \& Stichler, W. (1980). Environmental isotopes in ice and snow. Elsevier, 1, 141-178. 
Naranjo, L. (mayo de 2013). Caracterización hidrogeológica de la subcuenca del río Chambo. Riobamba, Chimborazo, Ecuador.

Natura medioambiental. (n.d.).

Ojeda, E. (2000). Informe Nacional sobre la Gestión del agua en Colombia. Bogotá.

Osorno, A. (2003). Situación actual y perspectivas del sector agua potable y saneamiento ambiental en el marco de las políticas existentes a nivel nacional. Bogotá: Dirección de agua potable y saneamiento ambiental.

Parry, I. (2007). Are the Costs of reducing Greenhouse gases from passenger vehicles negative? Journal of Urban Economics, 62, 273-93.

Peñafiel, L. (2009). Geología y análisis del recurso hídrico subterráneo de la subcuenca del sur de Quito. (EPN, Ed.) Quito.

Pilar, J. (2012). Gestión y gerenciamiento de recursos hídricos: mucho más que una cuestión semántica. Voces en el Fénix(20).

Pinto, V., Gili, R., \& Velasco, F. (2010). Los viajes del agua en Madrid durante el antiguo régimen. Madrid, España: Fundación Canal Santa Isabel II.

Porto, F. M., \& La Laina Porto, R. (23 de 6 de 2008). Gestão de bacias hidrográficas. Estudos Avançados.

Pourrot, P. (1989). Estudios de Geografía. (EPN, Ed.) Quito, Ecuador.

Procel. (2008). Modelación del acuífero Pusuquí-San Antonio de Pichicncha. (EPN, Ed.) Quito.

Quispe, A. (2017). Caracterización Hidrometerológica y estimación del balance hídrico en la cuenca del río Chambo. Quito, Pichincha, Ecuador.

Rabatel, A., Francou, B., Soruco, A., Gomez , J., \& Cáceres, B. (2012). Current state of glaciers in the tropical Andes: a multi-century. The Cryosphere, 81-102. doi:10.5194/tc-7-81-2013

Ramirez, E., Francou, B., Cadier, E., \& Soruco, A. (2010). Uso de un GPR (Ground Penetring Radar) en glaciares tropicales: Colombia, Ecuador y Bolivia. Glaciares, nieves y hielos de América Latina: cambio climático y amenazas.

Retamal, R., Rojas, J., \& Parra, J. (2011). Percepción al cambio climático y a la gestión del agua: aportes de las estrategias metodológicas cualitativas para su comprensión. Ambiente \& Sociedade, 175-194. 
Reyes, P. (2006). El complejo ofiolítico Peltetec y su relación con las unidades metamórficas jurásicas de la Cordillera Real. Tesis de Grado. Escuela Politécnica Nacional, 169. Quito.

Rodgers, K. (1991). Proyecto Manejo y Conservación de la cuenca del río Pastaza. Organización de los Estados Americanos. Secretaría Ejecutiva para asuntos Económicos y Sociales, Desarrollo Social y Medio Ambiente, Washington.

Rogers, P., \& Hall, A. W. (2003). Gobernabilidad Efectiva del Agua. (7), 49.

Rozanski, K., Araguás, L., \& Gonfiantini, R. (1993). Isotopic patters in modern global precipitation. Geophysical Monograph series, 78.

Rozanski, K., Araguás, L., \& Gonfiantini, R. (n.d.). Isotopic patters in modern global precipitation. In: Smart.P.K: Lohmann.K.C: McKenzie, J: Savin,S. Climate Change in Continental Isotopic Records. Geophysical Monograph Series., 1(36), 778.

Salguero, D. (2017). Levantamiento geológico-estructural de la zona comprendida por la hoja topográfica de Guano escala 1:50.000. Provincia de Chimborazo. Proyecto de Titulación. Escuela Politécnica Nacional. Quito.

Santos, V., \& Gatsmans, D. (2016). Composição Isotópica de precipitação e a suas relações com a variabilidade climática. (F.-P. 2015/5749-2, Ed.) IX Encontro de Geociências e Medio Ambiente.

SENAGUA. (2012). Informe de gestión 2012 de la Secretaría Nacional del agua. Quito.

Senplades. (2012). Generación de Geoinformación para la gestión del territorio a nivel nacional escala 1:250.000. Cantón Guano, Chambo y Riobamba. Memoria Técnica, Quito.

Servicio Nacional de Meterología e Hidrología del Perú. (2009).

Silverio, W., \& Jaquet, J.-M. (2017). Evaluating glacier fluctuations in Cordillera Blanca (Peru) by remote sensing between 1987 and 2016 in the context of ENSO. Archives des Sciences, 145-162.

Sophocleous, M. (2002). Interactions between groundwater and surface water: the state of the Science. Hydrogeology Journal, 10, 52-67. doi:10.1007/s10040-001-0170-8 
Sosa, H., \& Guevara, S. (1978). Levantamiento Geológico de Riobamba. Dirección General de Geología y Minas.

Stille, P., \& Shields, G. (1997). Radiogenic Isotope Geochemistry of sedimentary and aquatic system. Springer-Verlang, 217.

Tennat, D. (1976). Instream flow regiments for fish, wildlife, recreation and related environmental resources. Fish series, 1, 6-10.

Thornthwaite, C., \& Mather, J. (1948). The water balance. Climatology, 104.

Trenberth, K., \& Philip, D. (2007). Observations: Surface and atmosferic climate change. In Climate change 2007: The Physical Science Basis. Contribution of Working Group I to the Fourth Assesment Report of the Intergovernmental Panel on Climate Change (pp. 236-336). New York.

Trow, R. (1976). Cuatro cortes por la faja metamórfica de la Cordillera Real. Boletín Científico Tecnológico.

Tucci, C. (2003). Águas Urbanas. Inundações urbanas na América do Sul. $A B R H$.

TULAS. (2003). Senagua. Obtenido de https://www.agua.gob.ec/wpcontent/uploads/downloads/2012/07/TEXTO_UNIFICADO_LEGISLACIO N_SECUNDARIA_i.pdf

UNHABITAT. (2011). Solid Waste Management in the world's cities. Water and sanitation in the world's cities. (E. f. Programme, Ed.) UNHABITAT.

USEPA, United States Environmental Protection Agency. (1985). Quick Guide to drinking water sample collection.

USGS. (1966). Annual runoff in the conterminous United States.

Vásquez, J. (2008). Gestión de recursos hídricos en América Latina: Un asusnto de equidad y sostenibilidad. $A D$-Minister. Colombia: Universidad EAFIT.

Valente, O., \& Gomez, M. (2005). Conservação de nascentes. Viçosa-Minas Gerais: Aprenda fácil.

Villagómez, D. (2003). Evolución geológica Plio-Cuaternaria del Valle Interandino Central en Ecuador (Zona de Quito Guayllabamba-San Antonio). (T. d. Grado-EPN, Recopilador) Quito.

Vuille, M. (2008). Climate change and tropical Andean glaciers: past, present and future. Earth Sci., 83(3-4), 79-96.

Warner, J. (2005). Multi-Stakeholder Platforms: integrating society in water resource management? Ambiente e Sociedade, VIII(2). 
Winkler, W., Spikings, R., Villagómez, D., Eguez, A., Abegglen, P., \& Tobler, S. (2002). The Chota basin and its significance for the formation of the InterAndean Valley in Ecuador. Fourth ISAG, 705-708.

Winkler, W., Villagómez, D., Spikings , R., Tobler, S., Abegglen, P., \& Eguez, A. (2005). The Chota Basin and its significance for the inception and tectonic setting of the Inter-Andean Depression in Ecuador. Journal of South American Earth Sciences, 5-19.

Winter, T. (1995). Recent advances in understanding the interaction of groundwater and surface water. Geophys (Suppl), 985-994.

Winter, T., Avouac, J., \& Lavenu, A. (1993). Late Quaternary kinematics of the Pallatanga strike-slip fault (Central Ecuador) from topographic measurements of displaced morphological features. Geophysical Journal, 905-920.

Woessner, W. (2000). Stream and fluvial plain groundwater interactions: rescaling hydrogeologic thought. Ground Water, 38(3), 423-429.

Yánez. (2016). Caracterización e interpretación geológico-estructural de las secuencias Lito tectónicas de la Cordillera Real entre las Longitudes $78^{\circ} 34^{\prime}$ y $78^{\circ} 30^{\prime} \mathrm{O}$ y las Latitudes $1^{\circ} 40^{\prime}$ y $1^{\circ} 50^{\prime} \mathrm{S}$. al Este de Chambo. Provincia de Chimborazo. Tesis de Grado. Escuela Politécnica Nacional. 
10 ANEXOS

\section{ANEXO I: INFORMAÇÕES GEOLOGICAS}

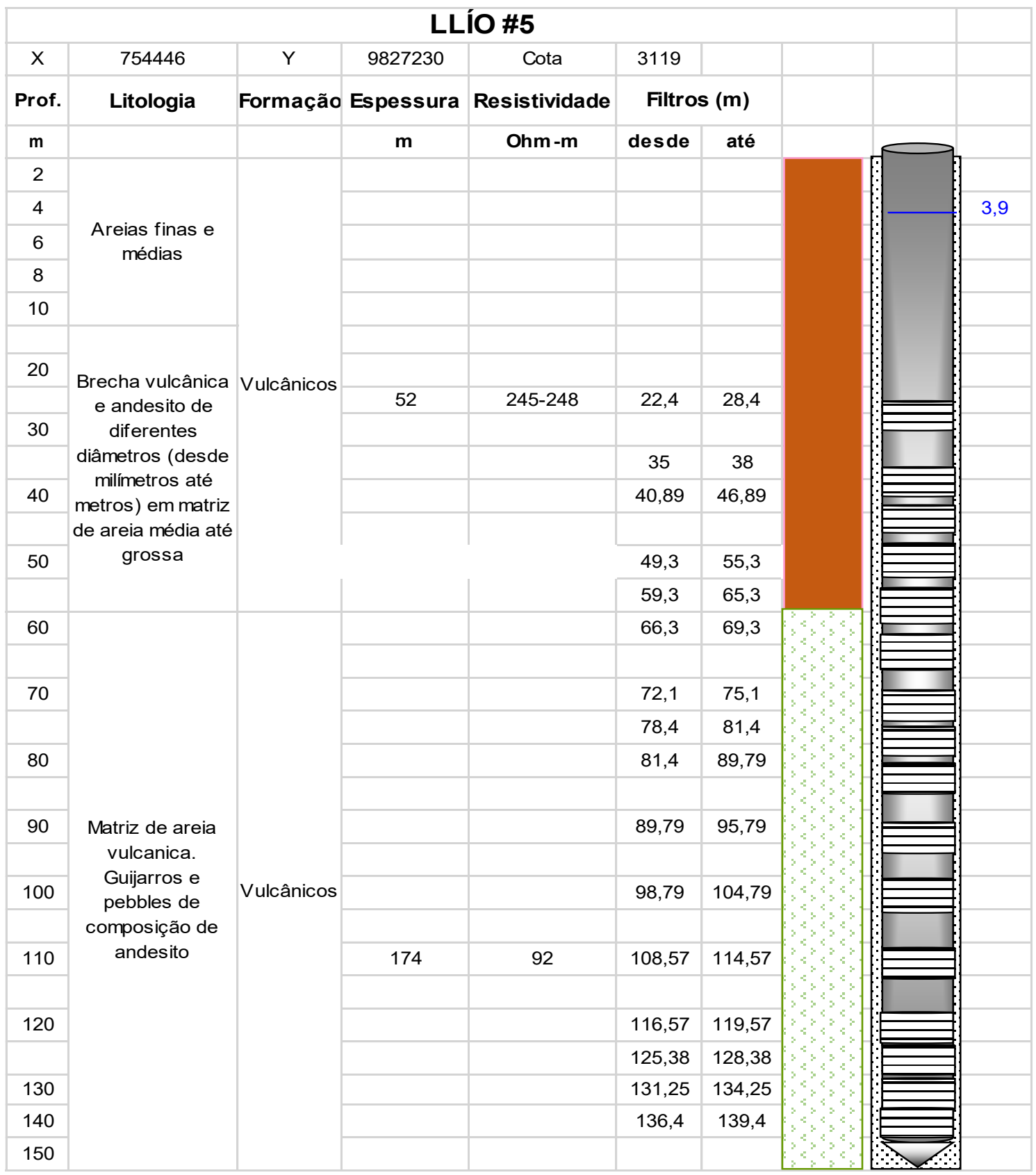




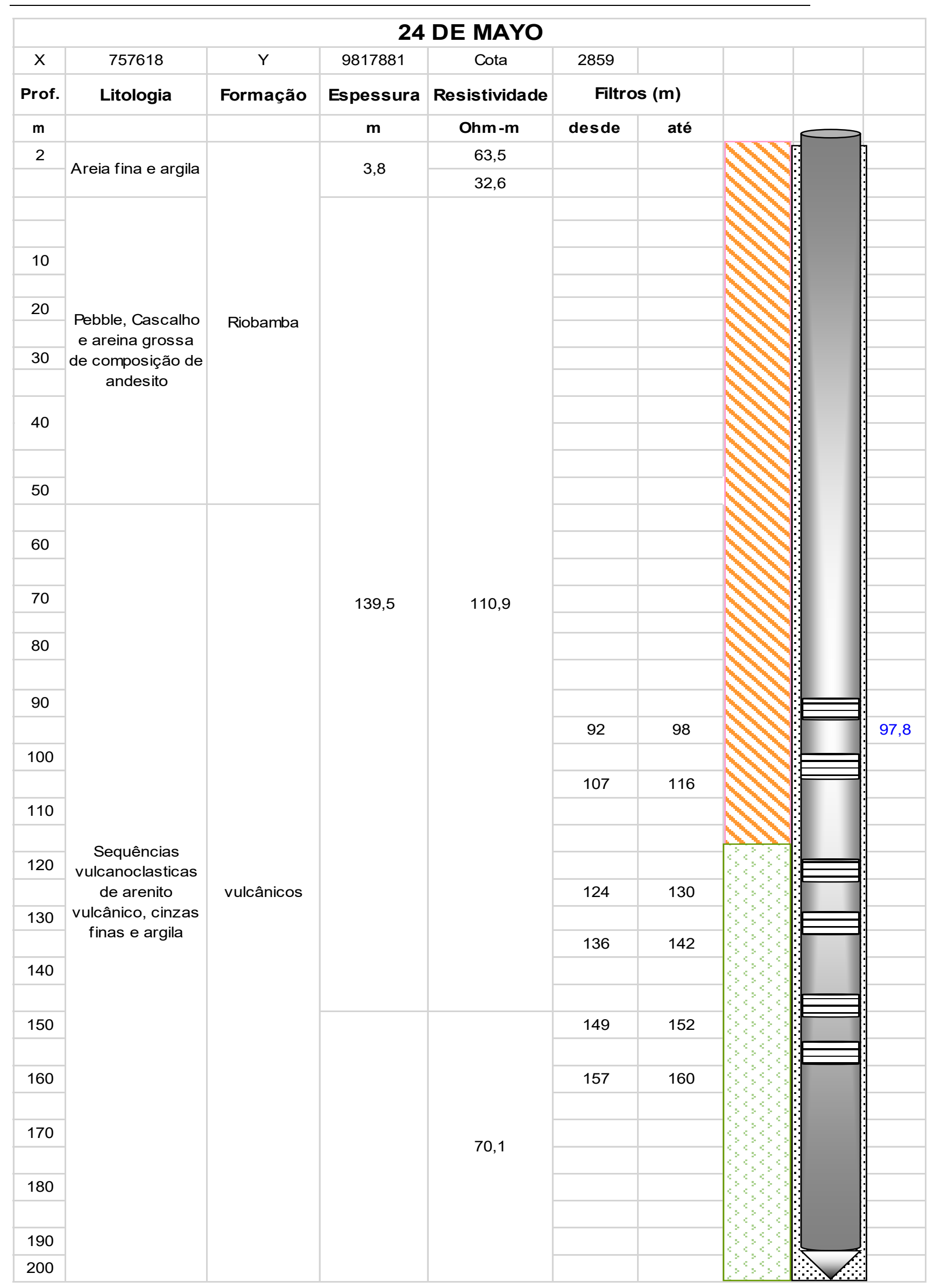




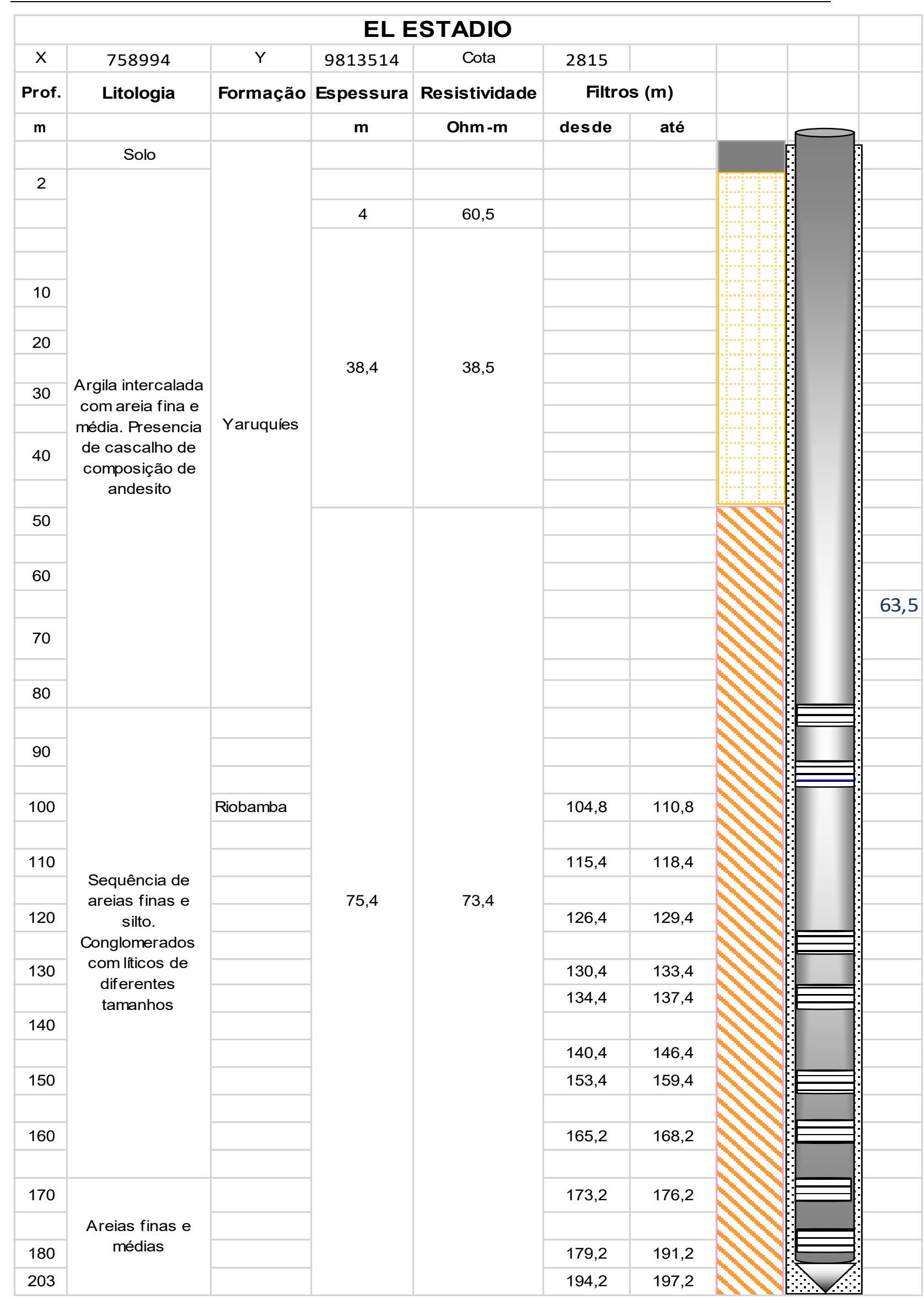




\section{REGISTRO DE FICHAS PETROGRÁFICAS}

\begin{tabular}{|c|c|c|}
\hline Código da amostra & Localização & Descrição (amostra de mão) \\
\hline M-PIMI1502RD & $\begin{array}{l}\text { Margem sul do rio } \\
\text { Daldal }\end{array}$ & $\begin{array}{l}\text { Rocha de cor verde escura e azul -gris muito escura. Composta de } \\
\text { minerais máficos alterados? A rocha também possui grande } \\
\text { quantidade de quartzo. }\end{array}$ \\
\hline M-PIMI1502RD & Norte do rio Daldal & $\begin{array}{l}\text { Xistos de coloração verde e cinza clara com dobras. Bandas } \\
\text { milimétricas de quartzo alternam-se com bandas mais micáceas, } \\
\text { clorita. Minerais intemperizados mudando para argilas (Imagen 1) }\end{array}$ \\
\hline M-PIMI1502SPS & $\begin{array}{l}\text { Localidade San Pablo } \\
\text { de Sali }\end{array}$ & $\begin{array}{l}\text { Rocha com fraturamento forte, de coloração verde escura com } \\
\text { microbandas de quartzo. } \\
\text { No afloramento observasse vulcanossedimentos intercalados nas } \\
\text { rochas. }\end{array}$ \\
\hline M-PIMI1502P & $\begin{array}{l}\text { Localidade Peltetec, } \\
\text { Córrego Moscón. } \\
\text { Margem direita do Rio } \\
\text { Chambo, no caminho } \\
\text { para Palitahua }\end{array}$ & $\begin{array}{l}\text { Rocha ígnea de cor marrão claro com minerais intemperizados. } \\
\text { Bandas finas de minerais de intemperismo? Grau de visibilidade } \\
\text { afanítica. }\end{array}$ \\
\hline
\end{tabular}




\begin{tabular}{|c|c|c|}
\hline Código da amostra & Localização & Descrição (amostra de mão) \\
\hline M-PIMI1502ECHLlio & $\begin{array}{l}\text { Llío e San Pablo, nos } \\
\text { afloramentos expostos } \\
\text { no campo de poços e } \\
\text { nascente. }\end{array}$ & $\begin{array}{l}\text { Afloramento com granulometria grossa e está pobremente } \\
\text { selecionada e sem estratificação. Clastos claros e escuros (cinza } \\
\text { escuro) de diâmetro variável, fraturados, de composição andesítica } \\
\text { envolvido em matriz de cinza até areia fina e média (Imagem 2). }\end{array}$ \\
\hline M-PIMI1502EACHGuano & $\begin{array}{l}\text { No caminho Guano- } \\
\text { Riobamba }\end{array}$ & $\begin{array}{l}\text { Afloramento beije com granulometria média até fina sem } \\
\text { estratificação. Clastos escuros (cinza escuro) de } 2 \mathrm{~cm} \text { até } 80 \mathrm{~cm} \text {, } \\
\text { fraturados, de composição andesítica envolvido em matriz de cinza } \\
\text { até areia fina e média (Imagem 3). }\end{array}$ \\
\hline M-PIMI1502EAFR & $\begin{array}{l}\text { Estrada Cubijíes- } \\
\text { Quimiag. }\end{array}$ & $\begin{array}{l}\text { Siltos e areias muito finas com espessuras variáveis. } \\
\text { Conglomerados de cores claras (bege principalmente) com clastos } \\
\text { e fragmentos arredondados e sub-arredondados de } 2 \mathrm{~mm}-4 \mathrm{~mm} \text {. }\end{array}$ \\
\hline M-PIMI1502EAFR2 & $\begin{array}{l}\text { No caminho Riobamba- } \\
\text { Los Elenes, setor de } \\
\text { piscinas. }\end{array}$ & $\begin{array}{l}\text { Sequência vulcanoclástica composta de arenitos vulcânicos de } \\
\text { cores claras, principalmente bege e cinza clara dispostas } \\
\text { horizontalmente. } \\
\text { Camadas de } \sim 4 \mathrm{~cm} \text { de arenitos médios, finos e grossos (Imagem } 4 \text { ). }\end{array}$ \\
\hline M-PIMI1502IG & $\begin{array}{l}\text { Igualata, na localidade } \\
\text { Pungal }\end{array}$ & $\begin{array}{l}\text { Andesito de cor cinza clara, textura afanítica, com presencia de } \\
\text { olivina? De estrutura massiva. }\end{array}$ \\
\hline
\end{tabular}




\begin{tabular}{|c|c|c|}
\hline Código da amostra & Localização & Descrição (amostra de mão) \\
\hline M-PIMI1502IG & $\begin{array}{l}\text { Igualata, no caminho } \\
\text { llapo }\end{array}$ & $\begin{array}{l}\text { Sequência de cinzas claras bege, camadas de arenitos vulcânicos e } \\
\text { clastos de pedra pomes. }\end{array}$ \\
\hline M-PIMI1502FC & $\begin{array}{l}\text { No caminho Guano- } \\
\text { Ilapo }\end{array}$ & $\begin{array}{l}\text { Cinza compactada de cor beije de granulometria fina composta } \\
\text { essencialmente de cinza e vidro vulcânico (Imagem 5). }\end{array}$ \\
\hline
\end{tabular}


REFGISTRO FOTOGRAFICO
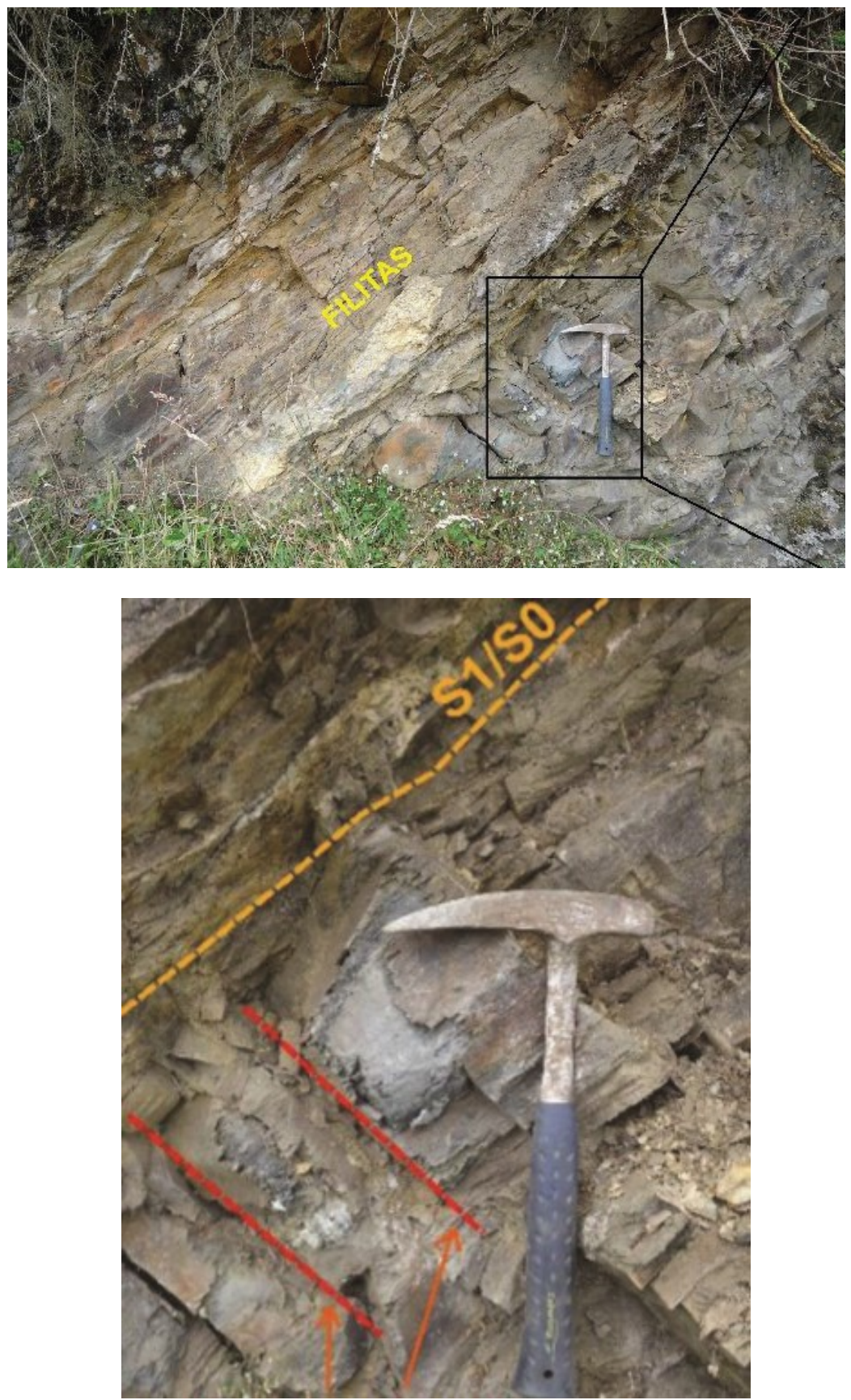

Imagem 1. Unidade rio Daldal. UTM 773357/9799824. Fonte: Yánez, 2016. 

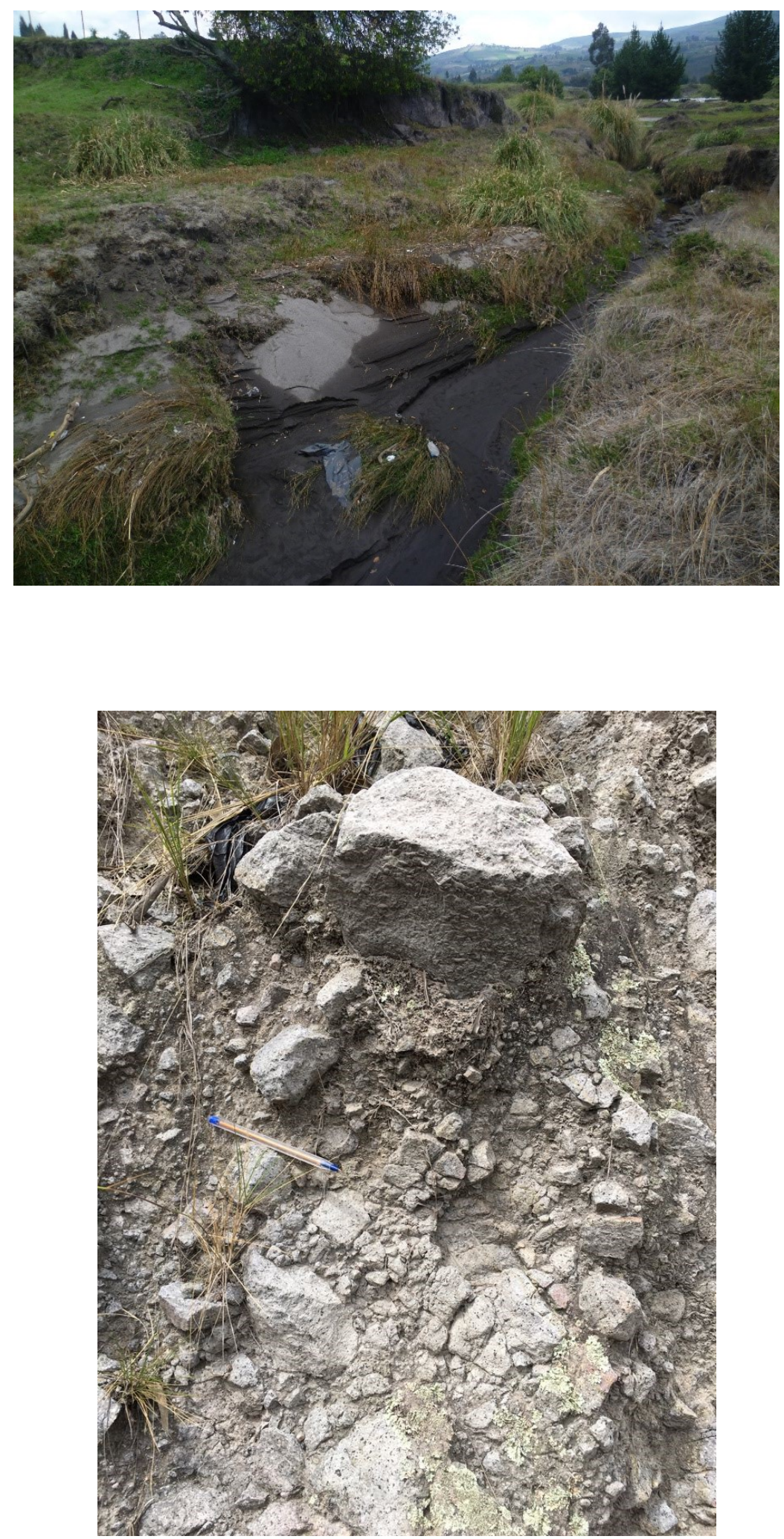

Imagem 2. Depósitos do Chimborazo.

UTM 754446/9827230 

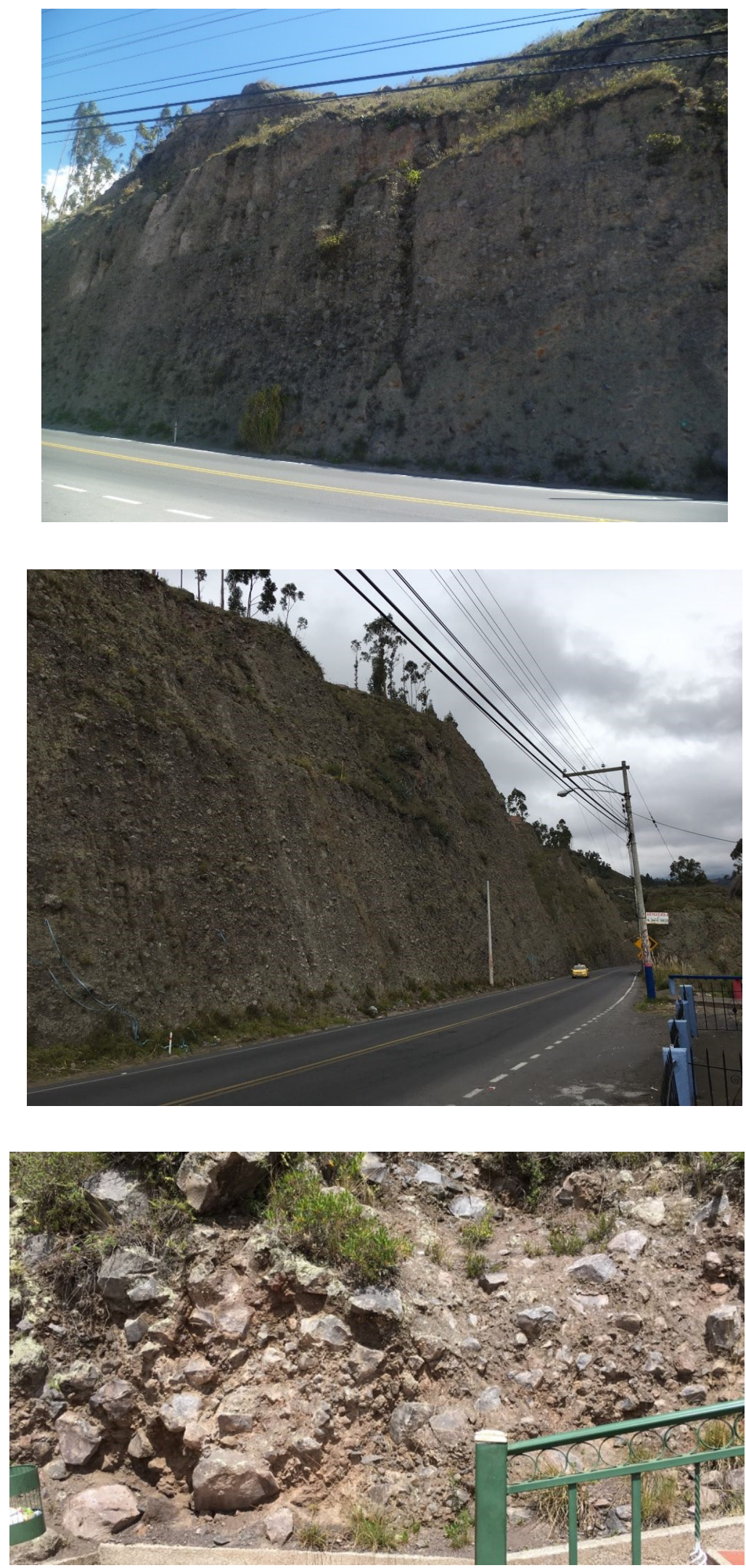

Imagem 3. Depósitos do Chimborazo. UTM 761803/9821841. 

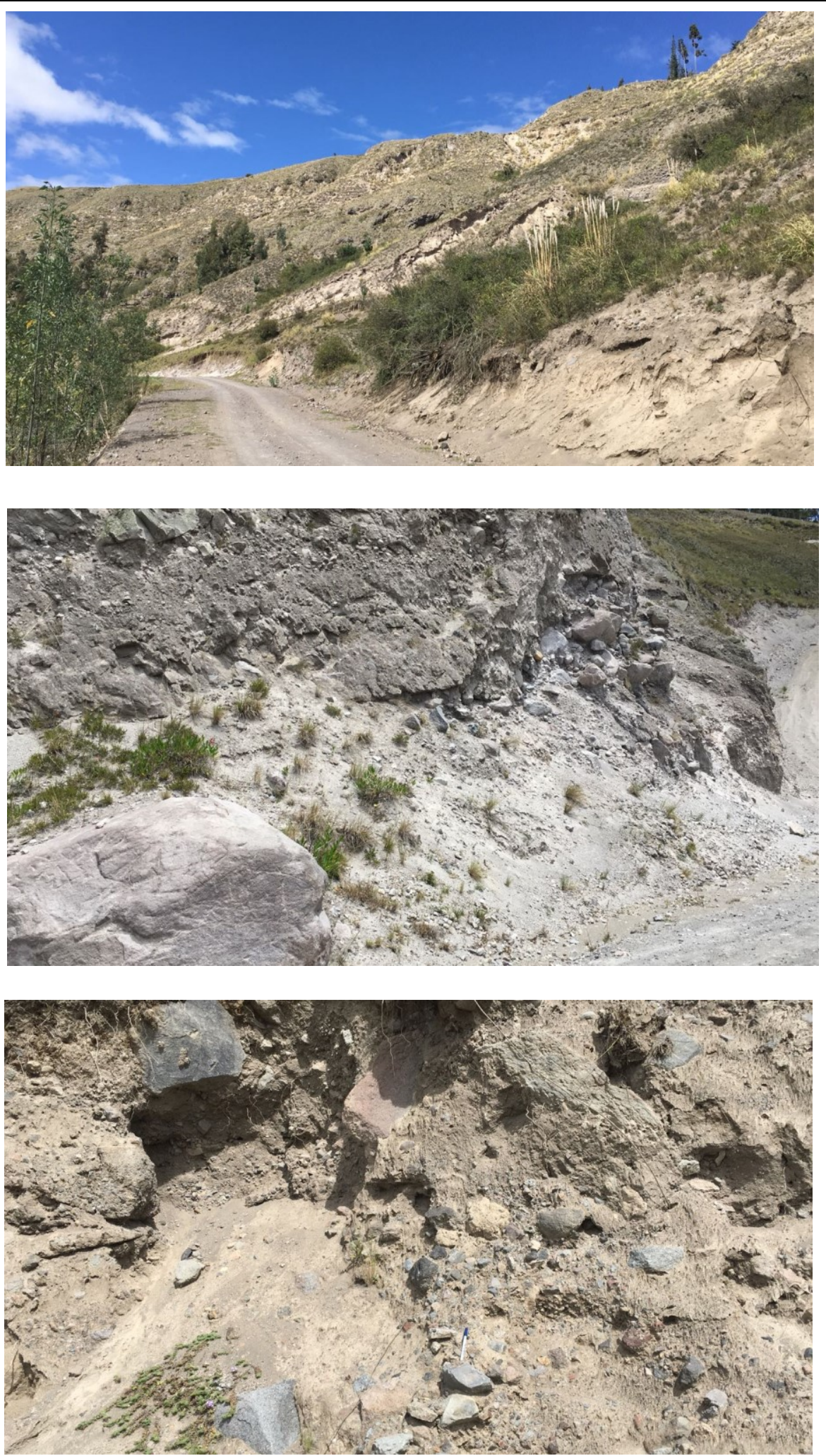

Imagem 4. Formação Riobamba UTM 766886/9821554. 

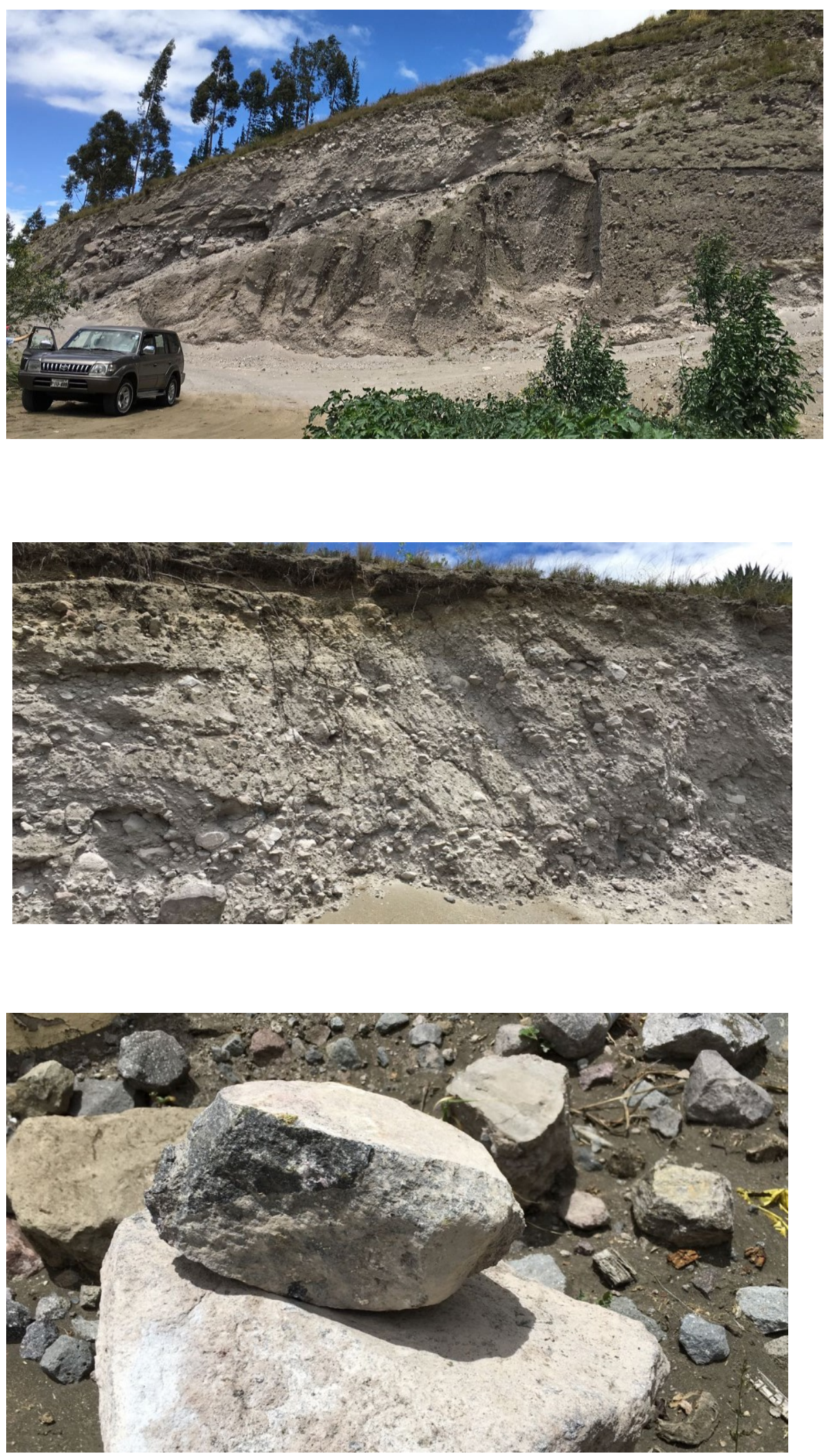

Imagem 6. Formação Riobamba

UTM 765861/9821106. 

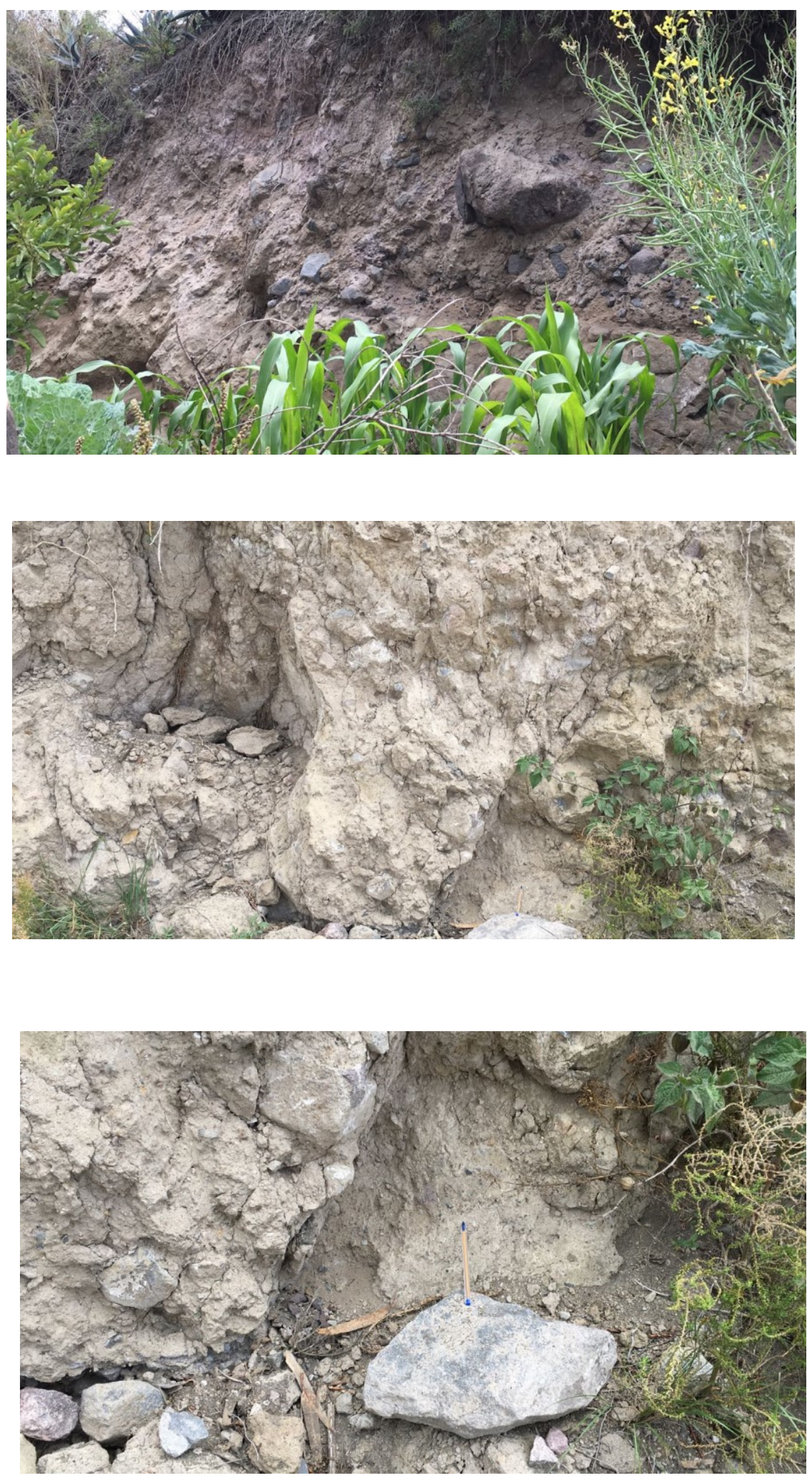

Imagem 7. Depósitos vulcânicos Igualata UTM763701/9822562 
ANEXO II: HIDROMETEOROLOGIA

Curvas de dupla massa
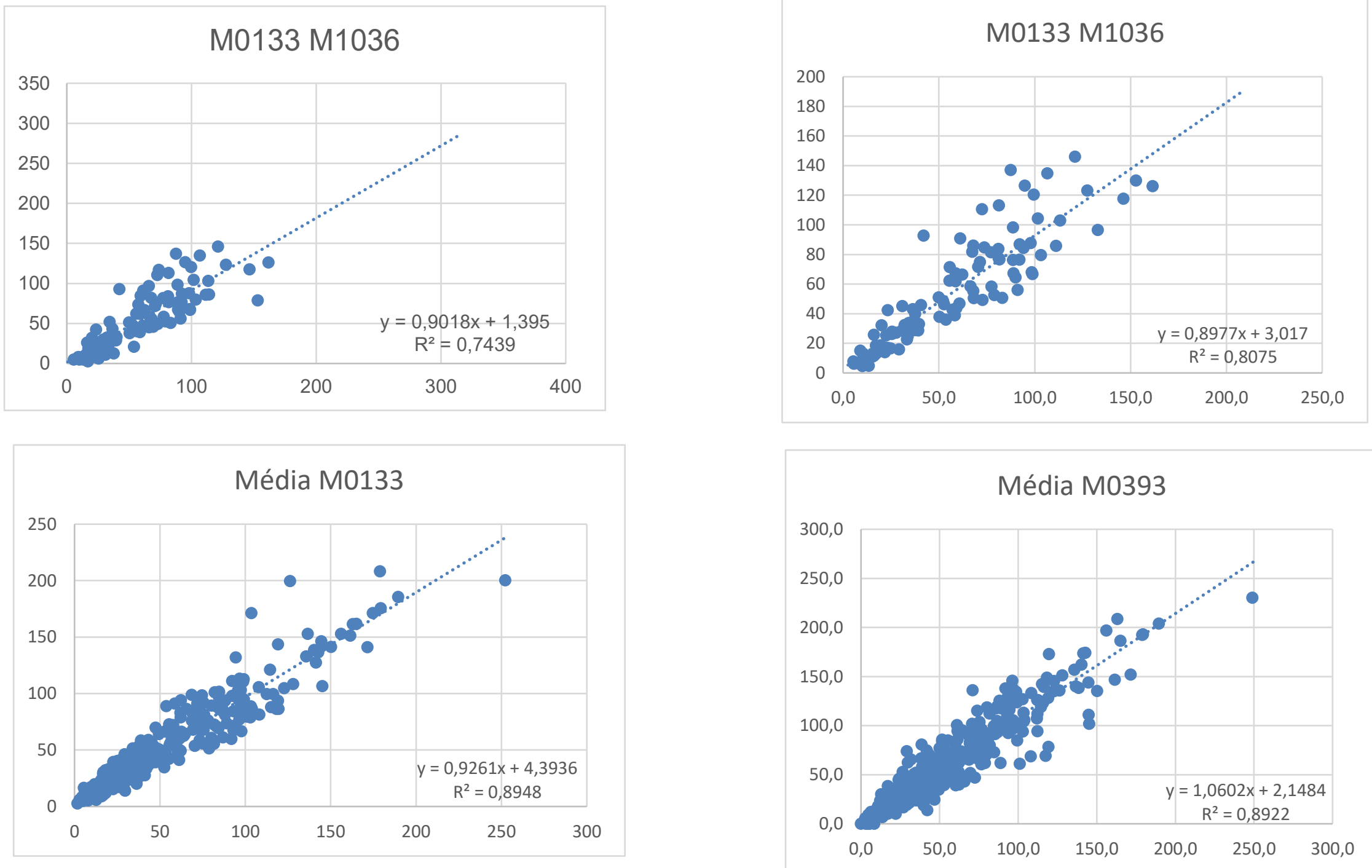


\section{Precipitação média mensal}

\begin{tabular}{|c|c|c|c|c|c|c|c|c|c|c|c|c|c|}
\hline Cógido & Estação & & & & & & Prec & itação & $\mathrm{nm})$ & & & & \\
\hline & & janeiro & fevereiro & março & abril & maio & junho & julho & agosto & setembro & outubro & novembro & dezembro \\
\hline M0057 & Riobamba aeropuerto & 29,9 & 53,8 & 53,0 & 61,4 & 52,0 & 32,8 & 14,9 & 23,7 & 31,2 & 44,4 & 44,0 & 37,1 \\
\hline M0133 & Guaslán & 40,4 & 59,0 & 74,7 & 89,4 & 61,3 & 37,7 & 22,8 & 20,7 & 38,8 & 65,3 & 60,3 & 52,9 \\
\hline M0243 & Pungales & 32,7 & 44,1 & 62,0 & 76,3 & 83,9 & 43,5 & 36,8 & 21,8 & 30,9 & 38,2 & 41,1 & 24,8 \\
\hline M0393 & San Juan Chimborazo & 46,4 & 68,5 & 81,9 & 103,9 & 67,9 & 35,6 & 18,8 & 20,6 & 39,4 & 74,4 & 69,8 & 53,8 \\
\hline M0394 & Cajabamba & 50,2 & 71,3 & 79,9 & 108,1 & 76,6 & 45,0 & 27,0 & 23,6 & 45,5 & 75,3 & 63,6 & 55,2 \\
\hline M0408 & Guano & 33,2 & 46,0 & 58,7 & 70,1 & 45,8 & 28,5 & 13,5 & 12,6 & 23,7 & 46,3 & 45,8 & 36,4 \\
\hline M1036 & Riobamba politécnica & 40,6 & 56,2 & 67,7 & 86,0 & 60,4 & 31,0 & 22,2 & 22,7 & 37,2 & 58,3 & 61,8 & 50,4 \\
\hline
\end{tabular}

Precipitação média anual

\begin{tabular}{llcc}
\hline Estação & \multicolumn{1}{c}{ Nome } & $\begin{array}{c}\text { Cota } \\
\text { (m.s.n.m })\end{array}$ & $\begin{array}{c}\text { Precipitação } \\
(\mathrm{mm})\end{array}$ \\
\hline M0057 & Riobamba aeropuerto & 2760 & 500,1 \\
M0133 & Guaslán & 2850 & 628,8 \\
M0243 & Pungales & 2550 & 593,7 \\
M0393 & San Juan Chimborazo & 3220 & 684,1 \\
M0394 & Cajabamba & 3160 & 805,9 \\
M0408 & Guano & 2688 & 462,4 \\
M1036 & Riobamba politécnica & 2850 & 600,2 \\
M0400 & Penipe & 2460 & 575,1 \\
M0407 & Licto & 2865 & 1175,9 \\
\hline
\end{tabular}


Vazões das estações hidrológicas localizadas na bacia do rio Chambo

\begin{tabular}{|c|c|c|c|c|c|c|c|c|c|c|c|c|c|}
\hline \multirow{2}{*}{ Estação } & \multirow{2}{*}{ Nome } & \multicolumn{12}{|c|}{ Vazão média mensal (m³/s) } \\
\hline & & janeiro & fevereiro & março & abril & maio & junho & julho & agosto & setembro & outubro & novembro & dezembro \\
\hline H0787 & $\begin{array}{l}\text { Alao } \\
\text { (Serie de datos: 1962-2014) }\end{array}$ & 4,92 & 5,80 & 6,75 & 8,75 & 10,61 & 14,30 & 16,68 & 11,44 & 8,16 & 6,72 & 4,92 & 4,75 \\
\hline H0788 & $\begin{array}{l}\text { Puela } \\
\text { (Serie de datos: 1965-2015) }\end{array}$ & 10,62 & 11,80 & 12,85 & 13,93 & 15,92 & 21,38 & 20,46 & 15,39 & 12,63 & 10,78 & 9,10 & 9,59 \\
\hline H0789 & $\begin{array}{l}\text { Guargualla } \\
\text { (Serie de datos: 1964-2015) }\end{array}$ & 4,02 & 4,59 & 4,97 & 5,89 & 6,41 & 8,47 & 8,26 & 6,54 & 5,78 & 4,64 & 3,93 & 3,84 \\
\hline H0791 & $\begin{array}{l}\text { Balsacón en San andrés } \\
\text { (Serie de datos: 1962-2015) }\end{array}$ & 0,24 & 0,23 & 0,26 & 0,27 & 0,28 & 0,28 & 0,28 & 0,25 & 0,26 & 0,28 & 0,28 & 0,23 \\
\hline H0826 & $\begin{array}{l}\text { Chambo hda. Cahuaji } \\
\text { (Serie de datos: 1978-1998) }\end{array}$ & 34,84 & 43,50 & 50,45 & 62,66 & 66,96 & 87,95 & 96,59 & 71,38 & 55,31 & 47,31 & 36,45 & 36,52 \\
\hline
\end{tabular}

Vazão mensal das estações hidrológicas

\begin{tabular}{cccccc}
\hline Estação & $\begin{array}{c}\text { Q anual } \\
\mathrm{m}^{3} / \mathrm{s}\end{array}$ & $\begin{array}{c}\text { Q específico } \\
\mathrm{l} / \mathrm{s} / \mathrm{km}^{2}\end{array}$ & $\begin{array}{c}\text { Área bacia } \\
\mathrm{km}^{2}\end{array}$ & $\begin{array}{c}\mathrm{P} \\
\mathrm{mm} / \mathrm{ano}\end{array}$ & $\begin{array}{c}\mathrm{T} \\
{ }^{\circ} \mathrm{C}\end{array}$ \\
\hline $\mathrm{H} 0783$ & 3,05 & 45,88 & 66,47 & 578,50 & 11,54 \\
$\mathrm{H} 0786$ & 3,06 & 5,06 & 604,89 & 675,48 & 12,45 \\
$\mathrm{H} 0787$ & 8,79 & 74,72 & 117,64 & 1028,91 & 11,85 \\
$\mathrm{H} 0788$ & 13,62 & 64,84 & 210,07 & 1127,49 & 12,36 \\
$\mathrm{H} 0789$ & 5,81 & 30,66 & 189,49 & 934,37 & 12,04 \\
$\mathrm{H} 0790$ & 20,65 & 29,19 & 707,40 & 773,08 & 12,05 \\
$\mathrm{H} 0791$ & 0,24 & 10,62 & 22,62 & 694,68 & 12,77 \\
$\mathrm{H} 0826$ & 57,27 & 16,26 & 3523,22 & 780,02 & 12,51 \\
\hline
\end{tabular}


Vazões anuais das estações hidrológicas

\begin{tabular}{cccccc}
\hline Estação & $\begin{array}{c}\text { Q anual } \\
\mathrm{m}^{3} / \mathrm{s}\end{array}$ & $\begin{array}{c}\text { Q específico } \\
\mathrm{l} / \mathrm{s} / \mathrm{km}^{2}\end{array}$ & $\begin{array}{c}\text { Área bacia } \\
\mathrm{km}^{2}\end{array}$ & $\begin{array}{c}\mathrm{P} \\
\mathrm{mm} / \mathrm{ano}\end{array}$ & $\begin{array}{c}\mathrm{T} \\
{ }^{\circ} \mathrm{C}\end{array}$ \\
\hline $\mathrm{H} 0783$ & 3,05 & 45,88 & 66,47 & 578,50 & 11,54 \\
$\mathrm{H} 0786$ & 3,06 & 5,06 & 604,89 & 675,48 & 12,45 \\
$\mathrm{H} 0787$ & 8,79 & 74,72 & 117,64 & 1028,91 & 11,85 \\
$\mathrm{H} 0788$ & 13,62 & 64,84 & 210,07 & 1127,49 & 12,36 \\
$\mathrm{H} 0789$ & 5,81 & 30,66 & 189,49 & 934,37 & 12,04 \\
$\mathrm{H} 0790$ & 20,65 & 29,19 & 707,40 & 773,08 & 12,05 \\
$\mathrm{H} 0791$ & 0,24 & 10,62 & 22,62 & 694,68 & 12,77 \\
$\mathrm{H} 0826$ & 57,27 & 16,26 & 3523,22 & 780,02 & 12,51 \\
& & & & & \\
\hline
\end{tabular}

Temperatura média $\left({ }^{\circ} \mathrm{C}\right)$

\begin{tabular}{|c|c|c|c|c|c|c|c|c|c|c|c|c|}
\hline \multirow{2}{*}{ Estação } & \multicolumn{12}{|c|}{ Temperatura média $\left({ }^{\circ} \mathrm{C}\right)$} \\
\hline & Janeiro & Fevereiro & Março & Abril & Maio & Junho & Julho & Agosto & Setembro & Outubro & Novembro & Dezembro \\
\hline Riobamba_AeropuertoM0057 & 14,3 & 14,2 & 14,0 & 14,1 & 13,8 & 13,0 & 12,6 & 12,7 & 13,2 & 14,2 & 14,4 & 14,4 \\
\hline Guaslán-M0133 & 14,4 & 14,4 & 14,4 & 14,5 & 14,3 & 13,6 & 13,3 & 13,3 & 13,7 & 14,4 & 14,5 & 14,6 \\
\hline Pungales-M0243 & 15,1 & 15,1 & 15,1 & 15,0 & 15,0 & 14,7 & 14,1 & 14,3 & 14,7 & 15,4 & 15,3 & 15,5 \\
\hline $\begin{array}{c}\text { Riobamba_Politécnica- } \\
\text { M1036 }\end{array}$ & 14,4 & 14,1 & 14,3 & 14,2 & 13,9 & 13,4 & 12,9 & 13,1 & 13,5 & 14,5 & 14,6 & 14,2 \\
\hline
\end{tabular}


Velocidade do vento

\begin{tabular}{lcccccccccccc}
\hline Código & janeiro & Fevereiro & Março & Abril & Maio & Junho & Julho & Agosto & Setembro & Outubro & Novembro & Dezembro \\
\hline M0057 & 5,1 & 4,447 & 3,988 & 4,172 & 4,168 & 4,631 & 4,665 & 4,988 & 5,500 & 4,494 & 4,138 & 4,700 \\
M0133 & 2,980 & 2,648 & 3,016 & 2,424 & 2,895 & 2,898 & 3,207 & 3,483 & 3,205 & 2,919 & 3,070 & 2,680 \\
M0134 & 7,508 & 6,818 & 7,679 & 7,685 & 7,625 & 7,615 & 8,326 & 8,362 & 7,371 & 7,513 & 8,752 & 8,164 \\
M0243 & 7,943 & 7,783 & 7,169 & 7,350 & 7,314 & 7,600 & 8,285 & 8,708 & 8,443 & 7,746 & 7,538 & 7,940 \\
M1036 & 3,150 & 2,885 & 2,719 & 2,671 & 2,781 & 3,400 & 3,586 & 4,167 & 3,460 & 3,228 & 3,261 & 2,994 \\
M0390 & 8,550 & 7,900 & 8,100 & 7,950 & 9,100 & 8,550 & 9,200 & 8,233 & 6,800 & 8,600 & 5,250 & 8,533 \\
\hline
\end{tabular}




\section{ANEXO III: BALANÇO HÍDRICO LOCAL}

Vazões ecológicas para peixes, fauna, recreação e outros relacionados a recursos ambientais.

\begin{tabular}{|c|c|c|}
\hline \multirow[t]{2}{*}{ Descrição de vazões } & \multicolumn{2}{|c|}{ Regímenes de vazões recomendados } \\
\hline & Estação chuva & Estação seca \\
\hline Máximo & $200 \%$ da vazão média & $200 \%$ vazão média \\
\hline Ótimo & 60 -100\% vazão média & 60 -100\% vazão média \\
\hline Sobressaliente & $40 \%$ & $60 \%$ \\
\hline Excelente & $30 \%$ & $50 \%$ \\
\hline Bom & $20 \%$ & $40 \%$ \\
\hline Degradante & $10 \%$ & $30 \%$ \\
\hline Pobre o mínimo & $10 \%$ & $10 \%$ \\
\hline Grave degradação & $10 \%$ & $10 \%$ \\
\hline
\end{tabular}

Fonte: Tennant, prescrição de regime de vazões ecológicas para peixes, fauna, recreação e outros relacionados a recursos ambientais. 


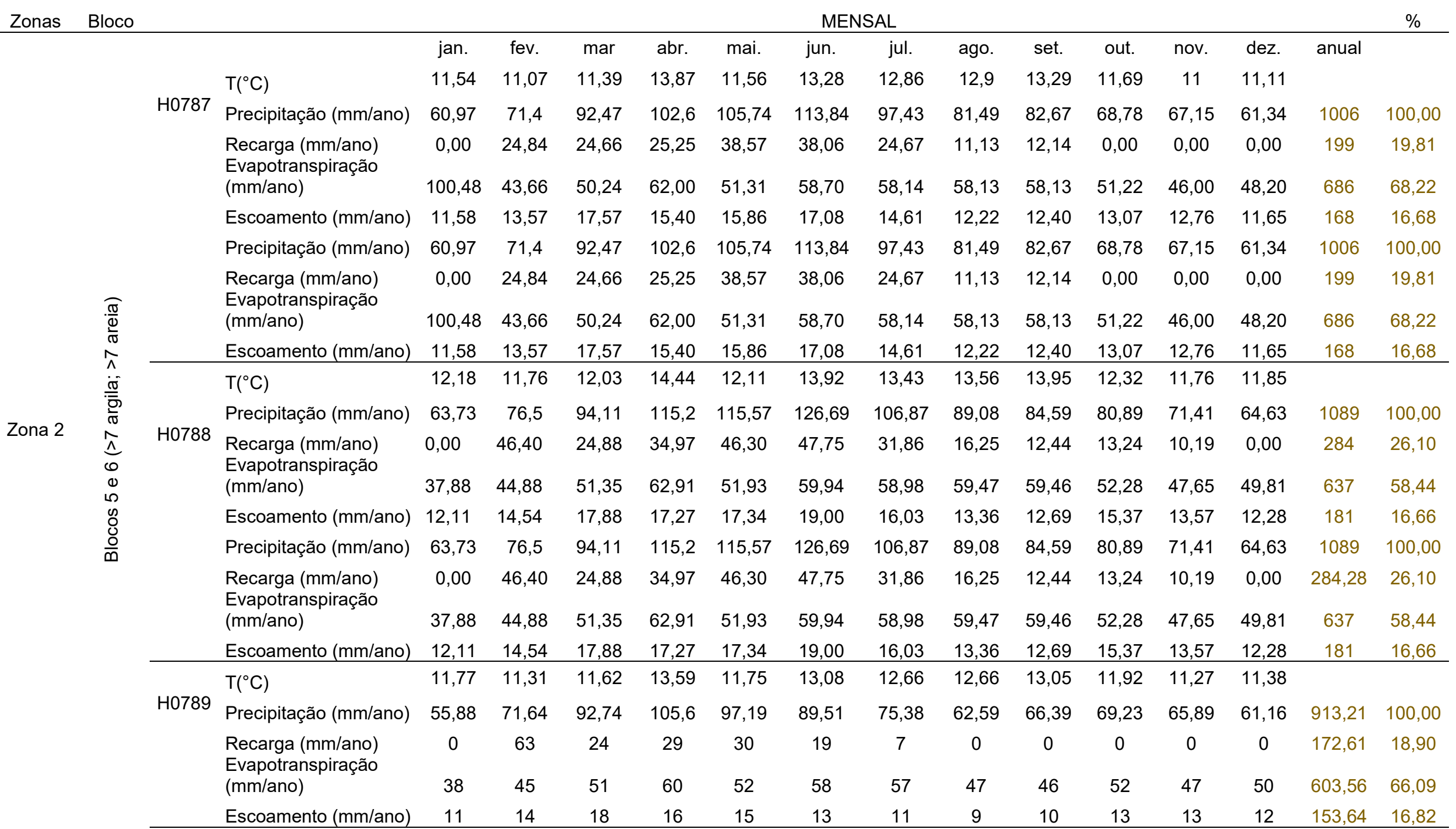




\begin{tabular}{|c|c|c|c|c|c|c|c|c|c|c|c|c|c|c|c|c|c|}
\hline \multirow[t]{2}{*}{ Zonas } & \multirow{2}{*}{\multicolumn{2}{|c|}{ Bloco }} & \multicolumn{15}{|c|}{ MENSAL } \\
\hline & & & & jan. & fev. & mar & abr. & mai. & jun. & jul. & ago. & set. & out. & nov. & dez. & anual & $\%$ \\
\hline \multirow{5}{*}{ Zona 3} & \multirow{5}{*}{ 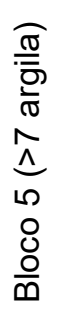 } & \multirow{5}{*}{$\begin{array}{l}0 \\
\text { N } \\
\text { o } \\
\text { 오 }\end{array}$} & $\mathrm{T}\left({ }^{\circ} \mathrm{C}\right)$ & 12,37 & 11,96 & 12,23 & 13,82 & 12,27 & 13,26 & 12,83 & 12,87 & 13,26 & 12,5 & 11,98 & 12,07 & & \\
\hline & & & $\begin{array}{l}\text { Precipitação } \\
\text { (mm/ano) }\end{array}$ & 48,48 & 66,13 & 82,53 & 97,51 & 81,64 & 63,65 & 50,34 & 42,34 & 49,76 & 67,88 & 61,79 & 54,84 & 766,89 & 100,00 \\
\hline & & & Recarga (mm/ano) & 0,00 & 0,00 & 29,31 & 22,81 & 15,96 & 0,00 & 0,00 & 0,00 & 0,00 & 0,00 & 0,00 & 0,00 & 68,08 & 8,88 \\
\hline & & & $\begin{array}{l}\text { Evapotranspiração } \\
\text { (mm/ano) }\end{array}$ & 54,55 & 46,42 & 53,06 & 60,07 & 53,43 & 47,23 & 48,85 & 49,34 & 48,18 & 53,87 & 49,38 & 40,93 & 605,31 & 78,93 \\
\hline & & & $\begin{array}{l}\text { Escoamento } \\
\text { (mm/ano) }\end{array}$ & 9,21 & 12,56 & 15,68 & 14,63 & 12,25 & 9,55 & 7,55 & 6,35 & 7,46 & 12,90 & 11,74 & 10,42 & 130,30 & 16,99 \\
\hline
\end{tabular}




\begin{tabular}{|c|c|c|c|c|c|c|c|c|c|c|c|c|c|c|c|c|c|}
\hline Zonas & Bloco & & & & & & ENSAL & & & & & & & & & & \\
\hline \multirow{22}{*}{ Zona 4} & \multirow{22}{*}{ 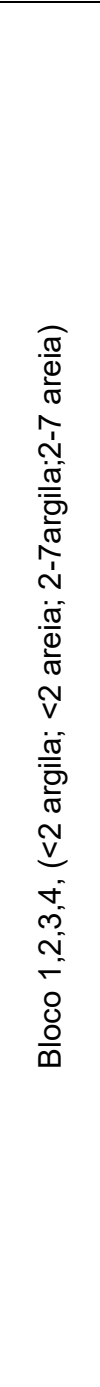 } & \multirow{22}{*}{$\begin{array}{l} \\
\\
\\
\text { 옹 } \\
\text { 오 }\end{array}$} & & jan & fev & mar & $a b r$ & mai & jun & jul & ago & set & out & nov & dez & anual & $\%$ \\
\hline & & & $\mathrm{T}\left({ }^{\circ} \mathrm{C}\right)$ & 12,71 & 12,32 & 12,56 & 14,16 & 12,56 & 13,49 & 13,04 & 13,15 & 13,54 & 12,83 & 12,38 & 12,45 & & \\
\hline & & & Bloco 1 & & & & & & & & & & & & & & \\
\hline & & & $\begin{array}{l}\text { Precipitação } \\
\text { (mm/ano) }\end{array}$ & 46,03 & 62,91 & 77,42 & 94,54 & 68,84 & 46,46 & 32,71 & 29,51 & 42,13 & 67,66 & 58,82 & 49,91 & 676,94 & 100,00 \\
\hline & & & Recarga (mm/ano) & 0,00 & 0,00 & 19,14 & 21,21 & 0,00 & 0,00 & 0,00 & 0,00 & 0,00 & 0,00 & 0,00 & 0,00 & 40,35 & 5,96 \\
\hline & & & $\begin{array}{l}\text { Evapotranspiração } \\
\text { (mm/ano) }\end{array}$ & 9,57 & 47,16 & 53,73 & 60,85 & 53,88 & 51,65 & 50,84 & 47,46 & 46,78 & 54,54 & 43,10 & 44,26 & 563,82 & 83,29 \\
\hline & & & $\begin{array}{l}\text { Escoamento } \\
\text { (mm/ano) }\end{array}$ & 7,36 & 10,07 & 12,39 & 12,48 & 9,09 & 6,13 & 4,32 & 3,90 & 5,56 & 10,83 & 9,41 & 7,99 & 99,51 & 14,70 \\
\hline & & & Bloco2 & & & & & & & & & & & & & 703,68 & 103,95 \\
\hline & & & $\begin{array}{l}\text { Precipitação } \\
\text { (mm/ano) }\end{array}$ & 46,03 & 62,91 & 77,42 & 94,54 & 68,84 & 46,46 & 32,71 & 29,51 & 42,13 & 67,66 & 58,82 & 49,91 & 676,94 & 100,00 \\
\hline & & & Recarga (mm/ano) & 0,00 & 0,00 & 19,14 & 21,21 & 0,00 & 0,00 & 0,00 & 0,00 & 0,00 & 0,00 & 0,00 & 0,00 & 40,35 & 5,96 \\
\hline & & & $\begin{array}{l}\text { Evapotranspiração } \\
\text { (mm/ano) }\end{array}$ & 9,57 & 47,16 & 53,73 & 60,85 & 53,88 & 51,65 & 50,84 & 47,46 & 46,78 & 54,54 & 43,10 & 44,26 & 563,82 & 83,29 \\
\hline & & & $\begin{array}{l}\text { Escoamento } \\
\text { (mm/ano) }\end{array}$ & 7,36 & 10,07 & 12,39 & 12,48 & 9,09 & 6,13 & 4,32 & 3,90 & 5,56 & 10,83 & 9,41 & 7,99 & 99,51 & 14,70 \\
\hline & & & Bloco 3 & & & & & & & & & & & & & 703,68 & 103,95 \\
\hline & & & $\begin{array}{l}\text { Precipitação } \\
\text { (mm/ano) }\end{array}$ & 46,03 & 62,91 & 77,42 & 94,54 & 68,84 & 46,46 & 32,71 & 29,51 & 42,13 & 67,66 & 58,82 & 49,91 & 676,94 & 100,00 \\
\hline & & & Recarga (mm/ano) & 0,00 & 0,00 & 18,37 & 12,89 & 0,00 & 0,00 & 0,00 & 0,00 & 0,00 & 0,00 & 0,00 & 0,00 & 31,25 & 4,62 \\
\hline & & & $\begin{array}{l}\text { Evapotranspiração } \\
\text { (mm/ano) }\end{array}$ & 9,11 & 47,16 & 53,73 & 60,85 & 37,97 & 47,56 & 47,96 & 44,87 & 43,08 & 54,54 & 42,51 & 43,76 & 533,09 & 78,75 \\
\hline & & & $\begin{array}{l}\text { Escoamento } \\
\text { (mm/ano) }\end{array}$ & 7,83 & 10,69 & 13,16 & 20,80 & 15,14 & 10,22 & 7,20 & 6,49 & 9,27 & 11,50 & 10,00 & 8,48 & 130,79 & 19,32 \\
\hline & & & Bloco 4 & & & & & & & & & & & & & 695,13 & 102,69 \\
\hline & & & $\begin{array}{l}\text { Precipitação } \\
\text { (mm/ano) }\end{array}$ & 46,03 & 62,91 & 77,42 & 94,54 & 68,84 & 46,46 & 32,71 & 29,51 & 42,13 & 67,66 & 58,82 & 49,91 & 676,94 & 100,00 \\
\hline & & & Recarga (mm/ano) & 0,00 & 0,00 & 18,37 & 12,89 & 0,00 & 0,00 & 0,00 & 0,00 & 0,00 & 0,00 & 0,00 & 0,00 & 31,25 & 4,62 \\
\hline & & & $\begin{array}{l}\text { Evapotranspiração } \\
\text { (mm/ano) }\end{array}$ & 46,10 & 47,16 & 53,73 & 60,85 & 37,97 & 47,56 & 47,96 & 44,87 & 43,08 & 54,54 & 42,51 & 6,77 & 533,09 & 78,75 \\
\hline & & & $\begin{array}{l}\text { Escoamento } \\
\text { (mm/ano) }\end{array}$ & 7,83 & 10,69 & 13,16 & 20,80 & 15,14 & 10,22 & 7,20 & 6,49 & 9,27 & 11,50 & 10,00 & 8,48 & 130,79 & 19,32 \\
\hline
\end{tabular}


Zonas bloco

MENSAL

$\%$

\begin{tabular}{|c|c|c|c|c|c|c|c|c|c|c|c|c|c|c|c|c|c|}
\hline & & & & jan & fev & mar & $a b r$ & mai & jun & jul & ago & set & out & nov & dez & anual & \\
\hline & & & Bloco 3 & & & & & & & & & & & & & & \\
\hline \multirow{11}{*}{ Zona 5} & \multirow{11}{*}{ 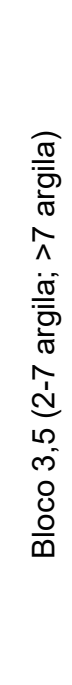 } & \multirow{11}{*}{ 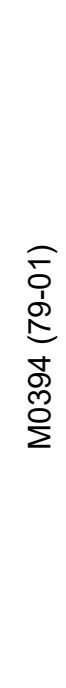 } & $\mathrm{T}\left({ }^{\circ} \mathrm{C}\right)$ & 13,60 & 13,54 & 13,61 & 14,00 & 13,75 & 13,88 & 13,26 & 13,27 & 13,79 & 13,99 & 13,61 & 13,85 & & \\
\hline & & & $\begin{array}{l}\text { Precipitação } \\
\text { (mm/ano) }\end{array}$ & 57,63 & 68,72 & 72,28 & 104,54 & 87,66 & 42,46 & 26,49 & 21,91 & 42,17 & 74,72 & 64,42 & 56,57 & 719,57 & 100,00 \\
\hline & & & Recarga (mm/ano) & 0,00 & 0,00 & 0,00 & 24,17 & 0,00 & 0,00 & 0,00 & 0,00 & 0,00 & 0,00 & 0,00 & 0,00 & 24,17 & 3,36 \\
\hline & & & $\begin{array}{l}\text { Evapotranspiração } \\
\text { (mm/ano) }\end{array}$ & 46,93 & 50,84 & 56,92 & 57,37 & 57,89 & 49,61 & 49,27 & 44,11 & 42,32 & 58,32 & 45,28 & 47,80 & 606,65 & 84,31 \\
\hline & & & $\begin{array}{l}\text { Escoamento } \\
\text { (mm/ano) }\end{array}$ & 9,80 & 11,68 & 12,29 & 23,00 & 19,29 & 9,34 & 5,83 & 4,82 & 9,28 & 12,70 & 10,95 & 9,62 & 138,59 & 19,26 \\
\hline & & & Bloco 5 & & & & & & & & & & & & & 769,40 & 106,93 \\
\hline & & & $\begin{array}{l}\text { Precipitação } \\
\text { (mm/ano) }\end{array}$ & 57,63 & 68,72 & 72,28 & 104,54 & 87,66 & 42,46 & 26,49 & 21,91 & 42,17 & 74,72 & 64,42 & 56,57 & 719,57 & 100,00 \\
\hline & & & Recarga (mm/ano) & 0,00 & 0,00 & 22,03 & 31,48 & 16,63 & 0,00 & 0,00 & 0,00 & 0,00 & 0,00 & 0,00 & 0,00 & 70,14 & 9,75 \\
\hline & & & $\begin{array}{l}\text { Evapotranspiração } \\
\text { (mm/ano) }\end{array}$ & 0,70 & 50,84 & 56,92 & 57,37 & 57,89 & 49,61 & 45,97 & 40,78 & 43,58 & 58,32 & 45,26 & 47,01 & 554,24 & 77,02 \\
\hline & & & $\begin{array}{l}\text { Escoamento } \\
\text { (mm/ano) }\end{array}$ & 10,95 & 13,06 & 13,73 & 15,68 & 13,15 & 6,37 & 3,97 & 3,29 & 6,33 & 14,20 & 12,24 & 10,75 & 123,71 & 17,19 \\
\hline & & & & & & & & & & & & & & & & 748,09 & 103,96 \\
\hline
\end{tabular}


Bloco 2

$\mathrm{PM0057( \textrm {mm } )}$

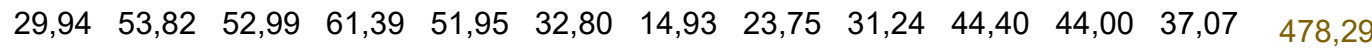

$\mathrm{T}\left({ }^{\circ} \mathrm{C}\right)$

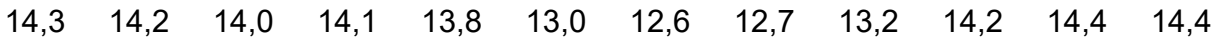

Precipitação (mm/ano)

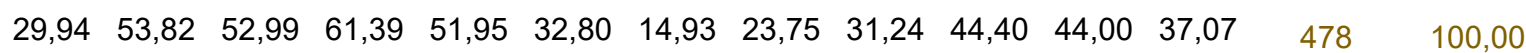

Recarga (mm/ano)

Zona 6

Evapotranspiração (mm/ano)

\begin{tabular}{|c|c|c|c|c|c|c|c|c|c|c|c|c|c|c|c|c|c|}
\hline & & & Recarga (mm/ano) & 0 & 0 & 0 & 0 & 0 & 0 & 0 & 0 & 0 & 0 & 0 & 0 & 0 & 0,00 \\
\hline & 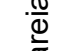 & & Evapotranspiração (mm/ano) & -56 & 45 & 49 & 50 & 50 & 42 & 35 & 34 & 36 & 43 & 42 & 38 & 408 & 85,26 \\
\hline 6 & $\stackrel{\sigma}{N}$ & 5 & Escoamento (mm/ano) & 5 & 9 & 8 & 8 & 7 & 4 & 2 & 3 & 4 & 7 & 7 & 6 & 70 & 14,74 \\
\hline
\end{tabular}

M01036

$\mathrm{PM01036}(\mathrm{mm})$

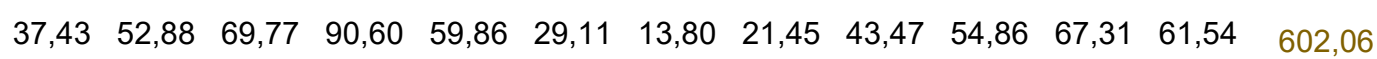

$\mathrm{T}\left({ }^{\circ} \mathrm{C}\right)$

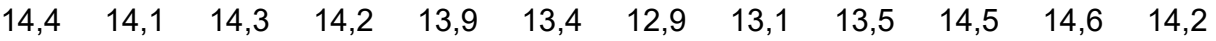

Precipitação (mm/ano)

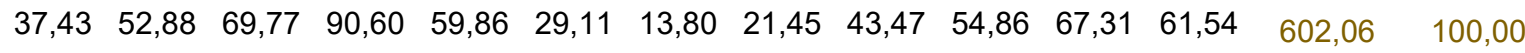

Recarga (mm/ano)

Evapotranspiração (mm/ano)

$\begin{array}{llllllllllllll}0 & 0 & 0 & 9 & 0 & 0 & 0 & 0 & 0 & 0 & 0 & 0 & 9 & 1,52\end{array}$

Escoamento (mm/ano)

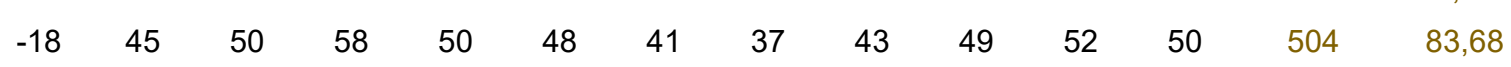

Bloco 2

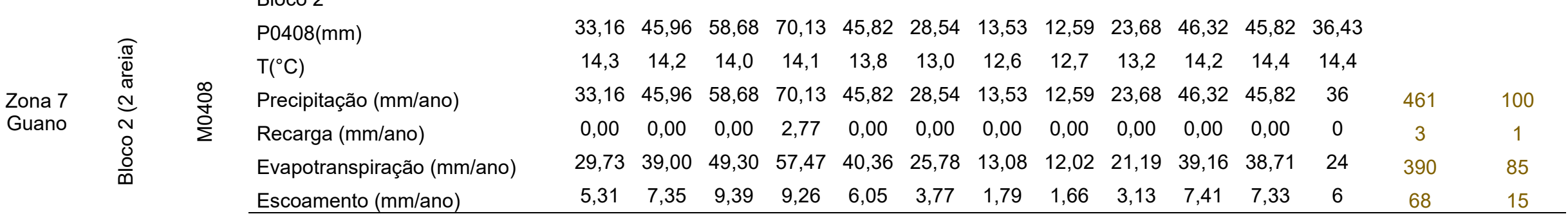




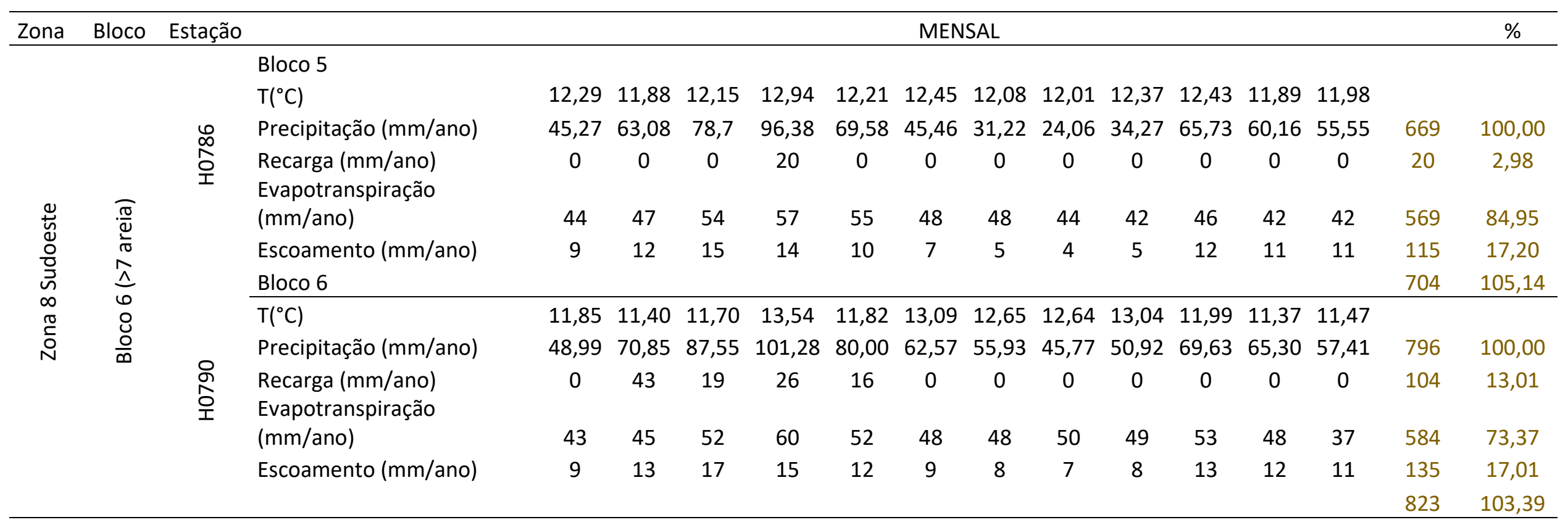




\section{ANEXO IV: CADASTRO DE POÇOS E NASCENTES}

Poços Llío-Guano

\begin{tabular}{cccccccccc}
\hline Simbologia & Poço & Zona & $X$ & $Y$ & $\begin{array}{r}\text { Cota } \\
(\mathrm{m})\end{array}$ & $\begin{array}{r}\text { Prof. } \\
(\mathrm{m})\end{array}$ & $\begin{array}{c}\text { NE } \\
(\mathrm{m})\end{array}$ & $\begin{array}{c}\text { ND } \\
(\mathrm{m})\end{array}$ & $\begin{array}{c}\text { Q } \\
\left(\mathrm{m}^{3} / \mathrm{h}\right)\end{array}$ \\
\hline 0 & Llío \#1 & Noroeste & 754475 & 9827340 & 3134 & 87,8 & & \\
1 & Llío \#2 & Noroeste & 754386 & 9827228 & 3119 & 97 & 24,0 & 24,0 & 223,8 \\
2 & Llío \#3 & Noroeste & 754395 & 9827005 & 3102 & 50 & 27,4 & 27,4 & 50,4 \\
3 & Llío \#4 & Noroeste & 754396 & 9826910 & 3098 & 168 & 20,8 & 20,8 & 165,6 \\
4 & Llío \#5 & Noroeste & 754446 & 9827230 & 3119 & 224 & 13,1 & 13,1 & 341,6 \\
5 & Llío \#6 & Noroeste & 754424 & 9827142 & 3103 & 61 & 14,6 & 14,6 & 165,7 \\
6 & Llío \#7 & Noroeste & 754483 & 9827029 & 3123 & 75 & 17,3 & 17,3 & 96,5 \\
\hline 0 & Langos & Centro & 759946 & 9821740 & 2638 & 257,5 & 206,2 & 206,2 & 5,3 \\
1 & Chingazo alto & Centro & 768776 & 9821784 & 2720 & 227 & 111,1 & 113,5 & 15,2 \\
2 & Gallipoggio & Centro & 766429 & 9818872 & 2618 & & & & \\
\hline
\end{tabular}


Poços Riobamba-Yaruquíes

\begin{tabular}{|c|c|c|c|c|c|c|c|c|c|}
\hline Simbologia & Poço & Zona & $\mathrm{X}$ & Y & $\begin{array}{r}\text { Cota } \\
(\mathrm{m})\end{array}$ & $\begin{array}{l}\text { Prof. } \\
(\mathrm{m})\end{array}$ & $\begin{array}{l}\text { NE } \\
(\mathrm{m})\end{array}$ & $\begin{array}{l}\text { ND } \\
(\mathrm{m})\end{array}$ & $\begin{array}{c}Q \\
\left(\mathrm{~m}^{3} / \mathrm{h}\right)\end{array}$ \\
\hline 0 & San Gabriel & Centro & 761379 & 9817732 & 2843 & 204 & 81,1 & 81,1 & 43,2 \\
\hline 1 & ESPOCH \#1 & Centro & 757705 & 9817078 & 2844 & 188 & & & 37,8 \\
\hline 2 & ESPOCH \#2 & Centro & 757694 & 9817074 & 2823 & 158,7 & & 77,3 & \\
\hline 3 & Brigada Galápagos & Centro & 760979 & 9816928 & 2833 & 200 & & & 30,0 \\
\hline 4 & UNACH & Centro & 762198 & 9816984 & 2793 & 175 & & & 54,0 \\
\hline 5 & Servidores & Centro & 759022 & 9816459 & 2822 & 190 & 70,0 & 70,0 & 115,2 \\
\hline 6 & Las Abras & Centro & 761874 & 9817955 & 2800 & 170 & 125,4 & 125,4 & 65,9 \\
\hline 7 & San Martin de Veranillo & Centro & 764096 & 9816447 & 2780 & 214 & 49,8 & 49,8 & 24,8 \\
\hline 8 & Cumandá & Centro & 763132 & 9817174 & 2776 & & 56,0 & 56,0 & 20,0 \\
\hline 9 & Huerta & Centro & 758498 & 9815993 & 2821 & 219 & 92,6 & 92,6 & 131,2 \\
\hline 10 & 21 de abril & Centro & 762580 & 9817459 & 2776,2 & 200 & 103,5 & 103,5 & 43,4 \\
\hline 11 & María auxiliadora & Centro & 760519 & 9812818 & 2777 & 258,5 & 106,8 & 106,8 & 13,7 \\
\hline 12 & Cdla, 24 de Mayo & Centro & 757618 & 9817881 & 2859 & 197 & & & \\
\hline 13 & Cdla, Balboa & Centro & 758420 & 9819623 & 2899 & & & & \\
\hline 14 & El Carmen II & Centro & 758140 & 9819959 & 2890 & 243,34 & 162,0 & 160,4 & 19,1 \\
\hline 15 & Lican & Centro & 757432 & 9819172 & 2895 & 212,5 & 71,5 & 71,5 & 38,0 \\
\hline 16 & Liribamba & Centro & 756684 & 9817300 & 2875 & & 96,3 & 96,3 & 26,3 \\
\hline 17 & San Antonio & Centro & 763392 & 9817550 & 2746 & 218,0 & & & 22,8 \\
\hline
\end{tabular}




\begin{tabular}{|c|c|c|c|c|c|c|c|c|c|}
\hline Simbologia & Poço & Zona & $x$ & $Y$ & $\begin{array}{r}\text { Cota } \\
(\mathrm{m})\end{array}$ & $\begin{array}{c}\text { Prof. } \\
\text { (m) }\end{array}$ & $\begin{array}{l}\mathrm{NE} \\
(\mathrm{m})\end{array}$ & $\begin{array}{l}\mathrm{ND} \\
(\mathrm{m})\end{array}$ & $\begin{array}{c}Q \\
\left(\mathrm{~m}^{3} / \mathrm{h}\right)\end{array}$ \\
\hline 18 & Parque Centenario & Centro & 759458 & 9817011 & 2814 & 188 & & & 108,0 \\
\hline 19 & El Areopuerto & Centro & 760790 & 9817687 & 2788 & 175 & & & 28,8 \\
\hline 20 & El Estadio & Sudeste & 758994 & 9813514 & 2815 & 200 & 63,5 & 63,5 & 108,0 \\
\hline 21 & Shuyo & Sudeste & 758947 & 9812997 & 2817 & 146,5 & 75,0 & 75,0 & 3,6 \\
\hline 22 & EL Pedregal & Sudeste & 759335 & 9813936 & 2794 & 225 & 57,2 & & 54,0 \\
\hline
\end{tabular}


Cadastro de nascentes

\begin{tabular}{|c|c|c|c|c|c|c|}
\hline Código & Nascente & Zona & $X$ & Y & $\begin{array}{c}\text { Cota } \\
(\mathrm{m})\end{array}$ & $\begin{array}{c}Q \\
\left(m^{3} / h\right)\end{array}$ \\
\hline$A$ & San Pablo \#1 & Noroeste & 753960 & 9827473 & 3120 & 864,00 \\
\hline B & San Pablo \#2 & Noroeste & 753952 & 9827172 & 3095 & 20,16 \\
\hline $\mathrm{C}$ & San Isidro & Noroeste & 757860 & 9825431 & 3020 & \\
\hline $\mathrm{D}$ & Quillotoro & Noroeste & 764140 & 9832887 & 3886 & \\
\hline$F$ & Almorzana Poggio & Noroeste & 739800 & 9831599 & 4050 & \\
\hline$x$ & De los Colibríes & Sudoeste & 740752 & 9832213 & 4003 & \\
\hline $\mathrm{Y}$ & De los Colibríes 2 & Sudoeste & 740030 & 9831653 & 3967 & \\
\hline B8 & Tatacto \# 7 & Centro & 753136 & 9829458 & 3200 & 72,00 \\
\hline B9 & Tatacto \# 8 & Centro & 758237 & 9831367 & 3200 & 72,00 \\
\hline B10 & Tugualag Chico \# 4 & Centro & 754214 & 9827466 & 3240 & 12,60 \\
\hline G & $\begin{array}{l}\text { G1 Guano } \\
\text { (pfuentes) }\end{array}$ & Centro & 762081 & 9822111 & 2700 & \\
\hline A2 & VCLavanderia & Centro & 768446 & 9818121 & 2503 & \\
\hline $\mathrm{A} 1$ & Guano Lavanderia & Centro & 762054 & 9821991 & 2719 & \\
\hline $\mathrm{H}$ & Gallipoggio & Centro & 766650 & 9818912 & 2613 & \\
\hline $\mathrm{C} 1$ & Los Elenes \# 16 & Centro & 764327 & 9821304 & 2610 & 54,00 \\
\hline $\mathrm{K}$ & 484/Los Elenes\#1 & Centro & 766073 & 9821090 & 2589 & \\
\hline L & 483/Los Elenes\#2 & Centro & 765923 & 9820896 & 2593 & \\
\hline M & 481/Los Elenes\#3 & Centro & 766886 & 9821554 & 2604 & \\
\hline $\mathrm{N}$ & Los Elenes \#4 & Centro & 765912 & 9821082 & 2560 & \\
\hline $\mathrm{O}$ & $\begin{array}{l}\text { Entre La Calera y } \\
\text { Cubijíes }\end{array}$ & Centro & 767626 & 9818816 & 2555 & 7,20 \\
\hline $\mathrm{P}$ & De la Calera & Centro & 767644 & 9818696 & 2562 & \\
\hline$Q$ & Cubijíes VC2 & Centro & 767644 & 9818696 & 2562 & \\
\hline $\mathrm{R}$ & Cubijíes CUB1 & Centro & 768456 & 9817915 & 2504 & 18,00 \\
\hline A3 & Cubijíes CO2 & Centro & 766886 & 9821554 & 2604 & \\
\hline D1 & El Ejido \# 22 & Centro & 768588 & 9818445 & 2560 & 1,80 \\
\hline $\mathrm{D} 2$ & $\begin{array}{l}\text { S. Gerardo Barrio } \\
\text { Unión \# } 18\end{array}$ & Centro & 764570 & 9819921 & 2590 & 1,80 \\
\hline D3 & Yuigan \# 17 & Centro & 766975 & 9819608 & 2610 & 14,40 \\
\hline$S$ & 485/Quimiag & Centro & 769295 & 9816142 & 2575 & 27,00 \\
\hline D4 & Matus \# 30 & Centro & 777417 & 9827749 & 2520 & 21,60 \\
\hline
\end{tabular}




\begin{tabular}{|c|c|c|c|c|c|c|}
\hline Código & Nascente & Zona & $x$ & $\mathrm{Y}$ & $\begin{array}{l}\text { Cota } \\
(\mathrm{m})\end{array}$ & $\begin{array}{c}\mathrm{Q} \\
\left(\mathrm{m}^{3} / \mathrm{h}\right)\end{array}$ \\
\hline D5 & $\begin{array}{l}\text { Pungal, Sta } \\
\text { Marianita \# } 27\end{array}$ & Leste & 775555 & 9826059 & 2420 & 36,00 \\
\hline D6 & Capil & Leste & 779416 & 9831862 & 2729 & 0,72 \\
\hline D7 & Palitahua \# 43 & Leste & 783914 & 9832898 & 2447 & 3,60 \\
\hline D8 & Pinicucho Bajo \# 18 & Leste & 774012 & 9829590 & 2630 & 1,08 \\
\hline D9 & $\begin{array}{l}\text { Puncal, Sta } \\
\text { Marianita \# } 26\end{array}$ & Leste & 771843 & 9822125 & 2425 & 3,60 \\
\hline $\mathrm{T}$ & Puente Pantaño & Sudoeste & 764525 & 9810144 & 2620 & 18,00 \\
\hline E1 & $\begin{array}{l}\text { B, Pte rio Chibunga } \\
\# 53\end{array}$ & Sudoeste & 764247 & 9810086 & 2590 & 36,00 \\
\hline E12 & Hda, Gahuin \# 58 & Sul & 773210 & 9802331 & 3360 & 7,20 \\
\hline E13 & Pogyohuaicu \# 60 & Sul & 769240 & 9797634 & 3080 & 7,20 \\
\hline E14 & $\begin{array}{l}\text { Tresquilapamba \# } \\
59\end{array}$ & Sul & 769240 & 9797789 & 3030 & 7,20 \\
\hline N1 & Abras 1 & Norte & 751723 & 9838031 & 3815 & \\
\hline O1 & Gabin \# 8 & Oeste & 744717 & 9826735 & 3520 & \\
\hline $\mathrm{O} 2$ & Calera Grande \# 5 & Oeste & 742150 & 9820532 & 3680 & \\
\hline O3 & H, Chaupi \# 2 & Oeste & 745090 & 9821171 & 3360 & \\
\hline
\end{tabular}


ANEXO V: TESTES DE BOMBEAMENTOS

Teste de bombeamento Brigada Galápagos
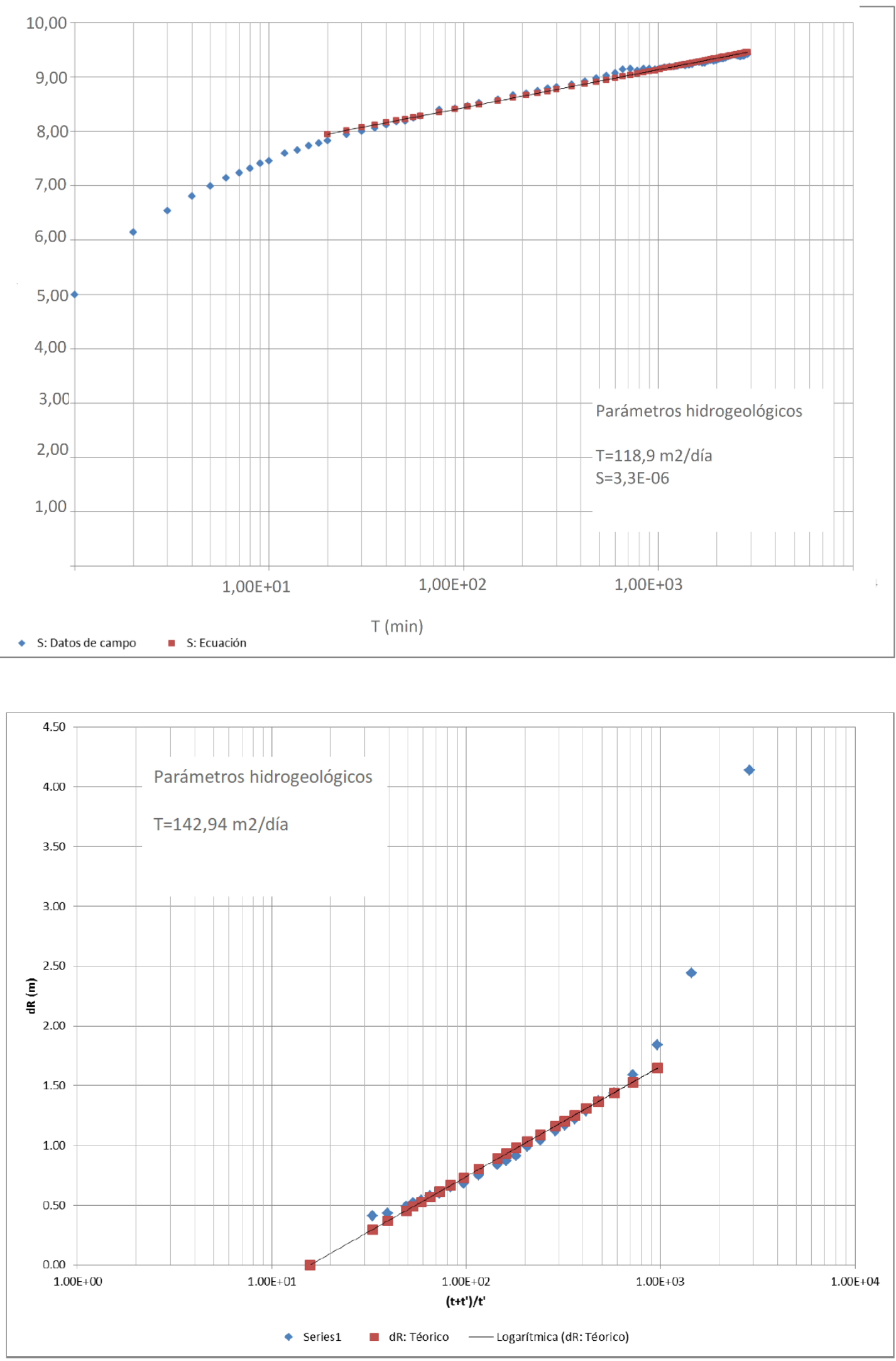
San Martín de Veranillo
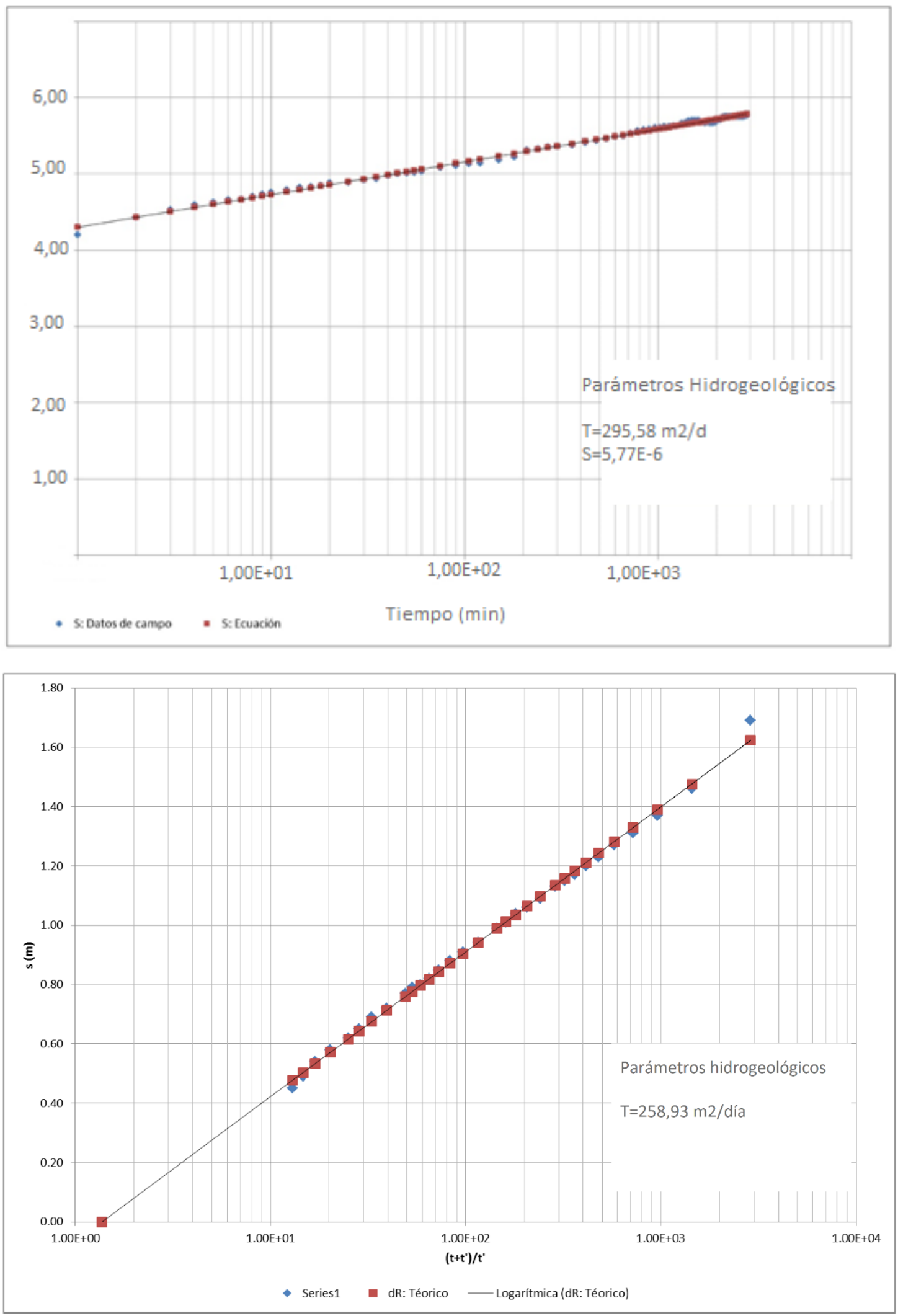


\section{ANEXO VI: HIDROQUIMICA E ISOTOPÍA}

Dados químicos e balanço iónico

\begin{tabular}{|c|c|c|c|c|c|c|}
\hline & Llío\#1 PA1 & Llío\#3 PA3 & Llío\#5 & & El Carmen & El Estadio \\
\hline $\mathrm{mg} / \mathrm{L}$ & $30 / 06 / 2016$ & $30 / 06 / 2016$ & $30 / 06 / 2016$ & 08/04/2013 & 08/04/2013 & 26/09/2012 \\
\hline $\mathrm{HCO}_{3}^{-}\left(\mathrm{CaCO}_{3}\right)$ & 170,42 & 191,79 & 258,81 & & & \\
\hline $\mathrm{HCO}_{3}^{-}\left(\mathrm{HCO}_{3}^{-}\right)$ & 207,91 & 233,98 & 315,75 & 285 & 408 & 600 \\
\hline $\mathrm{SO}_{4}^{-2}$ & 21,65 & 24,85 & 18,77 & & 269 & 273 \\
\hline $\mathrm{HPO}_{4}{ }^{-2}$ & 0,48 & 0,72 & 0,99 & 186,7 & & \\
\hline $\mathrm{Cl}^{-}$ & 4,83 & 5,99 & 6,82 & 5,7 & 2,8 & 82,2 \\
\hline $\mathrm{Br}^{-}$ & 1,06 & 0,98 & 1,62 & & & \\
\hline $\mathrm{NO}_{3}^{-}$ & 12,78 & 22,61 & 12,77 & & & 2,4 \\
\hline $\mathrm{NO}_{2}^{-}$ & 0,004 & 0,013 & 0,007 & & & \\
\hline $\mathrm{F}^{-}$ & 1,15 & 1,14 & 0,95 & & & \\
\hline $\mathrm{Na}^{+}$ & 25,36 & 31,74 & 32,25 & 121 & 64,2 & 190,2 \\
\hline $\mathrm{K}^{+}$ & 3,68 & 3,64 & 3,71 & & & 17,24 \\
\hline $\mathrm{Li}^{+}$ & 0,011 & 0,015 & 0,023 & & & \\
\hline $\mathrm{Ca}^{+2}$ & 28,04 & 29,57 & 30,40 & 30,4 & 80 & 35,43 \\
\hline $\mathrm{Mg}^{+2}$ & 26,94 & 31,42 & 45,42 & 60,3 & 93,3 & 18,11 \\
\hline $\mathrm{NH}_{4}^{+}$ & 0,02 & 0,03 & 0,03 & & & \\
\hline
\end{tabular}




\begin{tabular}{|c|c|c|c|c|c|c|}
\hline \multirow{2}{*}{ MEQ } & Llío\#1 PA1 & Llío\#3 PA3 & Llío\#5 & Los Chingazos & EL Carmen & El Estadio \\
\hline & $30 / 06 / 2016$ & $30 / 06 / 2016$ & $30 / 06 / 2016$ & 08/04/2013 & $08 / 04 / 2013$ & $26 / 09 / 2012$ \\
\hline $\mathrm{HCO}_{3}{ }^{-}$ & 3,41 & 3,83 & 5,17 & 4,67 & 6,69 & 9,83 \\
\hline $\mathrm{SO}_{4}^{-2}$ & 0,45 & 0,52 & 0,39 & 0,00 & 5,60 & 5,69 \\
\hline $\mathrm{HPO}_{4}^{-2}$ & 0,010 & 0,015 & 0,021 & 3,932 & & \\
\hline $\mathrm{Cl}^{-}$ & 0,14 & 0,17 & 0,19 & 0,16 & 0,08 & 2,32 \\
\hline $\mathrm{Br}^{-}$ & 0,01 & 0,01 & 0,02 & & & \\
\hline $\mathrm{NO}_{3}^{-}$ & 0,21 & 0,36 & 0,21 & & & 0,04 \\
\hline $\mathrm{NO}_{2}^{-}$ & 0,0001 & 0,0003 & 0,0001 & & & \\
\hline $\mathrm{F}^{-}$ & 0,06 & 0,06 & 0,05 & & & \\
\hline $\mathrm{Na}^{+}$ & 1,10 & 1,38 & 1,40 & 5,26 & 2,79 & 8,27 \\
\hline $\mathrm{K}^{+}$ & 0,09 & 0,09 & 0,10 & 0,00 & 0,00 & 0,44 \\
\hline $\mathrm{Li}^{+}$ & 1,40 & 1,48 & 1,52 & 1,52 & 3,99 & 1,77 \\
\hline $\mathrm{Ca}^{+2}$ & 2,22 & 2,58 & 3,74 & 4,96 & 7,68 & 1,49 \\
\hline $\mathrm{Mg}^{+2}$ & 0,0014 & 0,0019 & 0,0018 & & & \\
\hline Soma cátions & 4,81 & 5,54 & 6,75 & 11,74 & 14,46 & 11,97 \\
\hline Soma ânions & 4,28 & 4,97 & 6,06 & 8,76 & 12,37 & 17,88 \\
\hline Desvio & 5,83 & 5,35 & 5,45 & 14,52 & 7,80 & $-19,78$ \\
\hline
\end{tabular}

$\mathrm{MEQ}=$ miliequivalente 


\begin{tabular}{ccccccc}
\hline MEQ & $\begin{array}{c}\text { Llío\#5 } \\
25 / 09 / 2012\end{array}$ & $\begin{array}{c}\text { Langos } \\
07 / 04 / 2013\end{array}$ & $\begin{array}{c}\text { ESPOCH\#1 } \\
07 / 2010\end{array}$ & $\begin{array}{c}\text { Aeropuerto } \\
07 / 2010\end{array}$ & $\begin{array}{c}\text { San Martin de Veranillo } \\
08 / 04 / 2013\end{array}$ & $\begin{array}{c}\text { Pedregal } \\
07 / 2010\end{array}$ \\
\hline $\mathrm{HCO}^{-}$ & 6,69 & 4,35 & 5,81 & 2,27 & 6,69 & 6,82 \\
$\mathrm{SO}^{-2}$ & 0,62 & 6,19 & 0,72 & 0,73 & 3,98 & 4,69 \\
$\mathrm{Cl}^{-}$ & 0,36 & 0,08 & 0,83 & 0,19 & 0,04 & 2,08 \\
$\mathrm{NO}_{3}^{-}$ & 0,07 & & & 0,02 & & 0,18 \\
$\mathrm{~F}^{-}$ & & & & 0,06 & & 0,08 \\
$\mathrm{Na}^{+}$ & 0,61 & 5,89 & 2,22 & 2,65 & 4,15 & 12,14 \\
$\mathrm{~K}^{+}$ & 0,07 & 0,00 & 0,13 & 0,08 & & 2,66 \\
$\mathrm{Ca}^{+2}$ & 1,92 & 3,27 & 7,18 & 1,04 & 2,00 & 3,25 \\
$\mathrm{Mg}^{+2}$ & 0,00 & 8,15 & 0,22 & 0,36 & 2,00 & 4,52 \\
$\mathrm{Fe}^{+2}$ & & & & 0,0136 & & 22,58 \\
\hline Soma cátions & 2,59 & 17,32 & 9,74 & 4,15 & 8,14 & 13,85 \\
Soma ânions & 7,74 & 10,62 & 7,37 & 3,26 & 10,71 & 23,94 \\
Desvio & $-49,86$ & 23,98 & 13,83 & 11,91 & $-13,62$ & \\
\hline
\end{tabular}

